Universidade de São Paulo Escola de Comunicações e Artes Departamento de Artes Cênicas

\title{
Escuro: uma dramaturgia cúmplice
}

LEONARDO FARIA MOREIRA

São Paulo

2010 
Universidade de São Paulo

Escola de Comunicações e Artes

Departamento de Artes Cênicas

\section{Escuro: uma dramaturgia cúmplice}

\section{LEONARDO FARIA MOREIRA}

Dissertação apresentada à Escola de Comunicação e Artes da Universidade de São Paulo, como um dos requisitos para a obtenção do título de Mestre em Artes Cênicas.

Orientadora: Elisabeth Silva Lopes.

São Paulo

2010 


\section{FOLHA DE APROVAÇÃO}

Leonardo Faria Moreira

Escuro: uma dramaturgia cúmplice

Dissertação de mestrado apresentada ao Programa de Pós-Graduação da Escola de Comunicação e Artes da Universidade de São Paulo, como um dos requisitos para a obtenção do título de Mestre em Artes Cênicas.

Orientadora: Elisabeth Silva Lopes.

Aprovado em:

\section{Banca examinadora}

Prof(a). Dr(a).

Intituição:

Assinatura

Prof(a). Dr(a).

Intituição: Assinatura

Prof(a). Dr(a).

Intituição: Assinatura 
A meu pai, que já não pode me acompanhar na piscina, pela inspiração inicial. 
"So, this book is more the record of a process than a text for performance; a map rather than a play. A play is place which demands to be inhabited; both origin and destination, linked by a clearly determined path. A map indicates the landscape, suggests a multitude of directions, but does not dictate which one you should take. A map, however beautiful, is a guide not a site. If you wish to visit the site yourself, pick up Schulz's books. And travel." 


\section{AGRADECIMENTOS}

À Beth Lopes, pela tolerância, compreensão, troca e imenso aprendizado tanto como orientadora como parceira na Companhia de Teatro em Quadrinhos;

Ao elenco de Escuro - Aline Filócomo, André Blumenschein, Daniela Duarte, Fernanda Stefanski, Flávia Melman, Luciana Paes, Maria Amélia Farah, Otávio Dantas, Paula Picarelli e Thiago Amaral - pela generosidade, cumplicidade na criação e amizade.

A Aura Cunha e Maria Helena Chira, que dividiram comigo esta jornada.

A Christiane Riera, Luiz Fernando Ramos, Sérgio de Carvalho e Maria Thaís, por me ajudarem a descobrir novas diretrizes a este trabalho.

A minha família.

Esta pesquisa foi realizada com o financiamento da FAPESP - Fundação de Amparo à Pesquisa do Estado de São Paulo; 


\section{RESUMO}

Este estudo pretende usar conceitos relacionados a mídias de comunicação interativa e coletiva como ferramentas de análise e de proposição em um processo de criação dramatúrgica: um diagrama de peças potenciais que resultou no espetáculo "Escuro". Em outras palavras, acompanha-se o processo de criação do espetáculo, analisando-o através do transporte metafórico de conceitos propostos por Janet $\mathrm{H}$. Murray ao descrever narrativas em ambiente virtual (imersão, agência e autoria procedimental) e comparando-o a outros dramaturgos contemporâneos que serviram de modelo à criação. A primeira parte deste texto trata do ambiente digital a partir principalmente das teorias de Janet $\mathrm{H}$. Murray. A idéia é apontar terminologias particulares e descrever as principais características do ambiente digital, conceitos esses que serão utilizados como instrumentos de análise e metáforas para se falar de criação dramatúrgica. Na segunda parte, concretiza-se o transporte metafórico entre teatro e meio digital através de breves análises de fragmentos de dramaturgias contemporâneas que serviram de modelo à criação de "Escuro", particularmente as excursões à linguagem cotidiana e as paisagens do francês Michel Vinaver; o texto híbrido, que transita entre a realidade e o lirismo, do argentino Federico Léon; e um registro cênico do Theatre de Complicitè. Chegamos a um terceiro momento e centro do trabalho - quando, ao invés de usar conceitos do ambiente digital como ferramentas de leitura e análise, passa-se a utilizá-los como ferramentas de proposição, ou seja, de escrita. Unindo a teoria apresentada à experimentação prática, descreve-se o processo criativo do espetáculo "Escuro". A pesquisa abrange não só a análise do texto teatral, mas também a análise de sua construção. Não se trata, é claro, da documentação de um espetáculo em fase de preparação, mas de uma reflexão teórica sobre um processo de criação. Por fim, é apresentado o mapa dramatúrgico criado em processo com a colaboração de dez atores e um possível agenciamento, isto é, uma possível organização do hipertexto dramático.

Palavras-chave: dramaturgia contemporânea, hipertexto, imersão, agência, prática teatral. 


\section{ABSTRACT}

This study attempts to use concepts related to collective and interactive communication media as tools for analysis and proposition in a process of dramatic creation: a diagram of potential playwritings that resulted in the play "Escuro". In other words, we follow the process of creating that play, analyzing it through the metaphorical transport of some concepts proposed by Janet H.Murray to describe narratives in virtual environment (immersion, agency and procedural authorship) and comparing it to other contemporary playwrights who have served as a model for the creation. The first part of this text deals with the digital environment, mainly from the theories of Janet H.Murray. The idea is to point out particular terminologies and describe the main features of the digital environment, these concepts will be used as analytical tools and metaphors to talk about creating drama. In the second part, we finalize the metaphorical transport between theater and digital media through brief analysis of fragments of contemporary dramaturgy that has served as a model for the creation of "Escuro", particularly excursions to the daily language and the "landscapes" of the Michel Vinaver; the hybrid text, which moves between reality and lyricism, of Federico Leon, and a textual record of a Theatre de Complicitè's play. Then, we have reached a third time and the center of this work - when, instead of using concepts of the digital environment for reading and analysis, we use them as tools of proposition, namely writing. Uniting the presented theory to the practice, the creative process of "Escuro" is described. The research covers not only the analysis of the theatrical text, but also the analysis of its construction. It is not, of course, the documentation of a performance in preparation, but a theoretical reflection on the process of creation. Finally, we present the map created in a dramaturgical process with the collaboration of ten actors and a possible agency, a possible organization to the dramatic hypertext.

Keywords: contemporary playwriting, hypertext, immersion, agency, theatrical practice. 
INTRODUÇÃO

Entre extremos 09

Conduzindo à deriva em meio ao dilúvio .16

PARTE I - O AMBIENTE DIGITAL: DEFINIÇÕES

Breve passeio pelo bosque da hiperficção .22

Hipertexto 24

Imersão e Agência .26

Autoria Procedimental e Escrita Cúmplice .30

PARTE II - IMERSÃO E AGENCIA: HIPERTEXTUALIDADE EM DRAMATURGIAS

Alguns paralelos 34

Dramaturgias de Paisagem .36

Dramaturgia Hipertextual: O pedido de Emprego, de M. Vinaver .39

Agenciamento em Dramaturgia: 0 dissidente, de M. Vinaver .45

Autoria Procedimental: The Street of Crocodiles, Theatre de Complicitè .48

Imersão: Dramaturgias Híbridas . 54

Realidade e ficção na cena . 55

Realidade e ficção no texto teatral .66

PARTE III - MAPA DRAMATÚRGICO: "ESCURO"

Outros paralelos .71

A fábula .72

Narrativas em rede .75

O caleidoscópio .79

O mapa .82

Hipertextualidade .85

Trajetórias e personagens .87

Trajetórias de Convergência .88

Trajetórias Conluiadas 94

Trajetórias de Suporte .99

Imersão .103

Ator e Personagem .104

Primeira e terceira pessoas .107

A composição de uma paisagem .111

Agência .115

CONSIDERAÇÕES FINAIS

Por uma escrita cúmplice .119

REFERÊNCIAS . 122

ANEXOS .127 


\section{INTRODUÇÃO}

\section{Entre extremos}

Jean-Pierre Sarrazac, no primeiro capítulo de seu livro "O Futuro do Drama"1, nos lembra a imperativa necessidade do autor teatral em "escrever no presente", isto é, fazer com que sua obra artística corresponda a sua época. O teórico francês ressalta o teor rapsódico da dramaturgia francesa contemporânea a ele. Segundo Sarrazac, o "autor-rapsodo" mistura gêneros e registros - cria um "entrelaçado de temas", fragmentos reunidos que falam, a um só tempo, de variados modos: o trágico, o lírico e o épico. Em suas palavras,

\footnotetext{
"escritor-rapsodo (rhaptein em grego significa 'coser'), que junta o que previamente despedaçou e, no mesmo instante, despedaça o que acabou de unir." ${ }^{2}$
}

Parece óbvio que o formato dos textos tenha mudado ao longo dos séculos, mas é importante notar como o status do texto teatral mudou radicalmente desde a década de 60 , com florescimento, dentro da cena teatral, do que temos nos habituado a chamar da "estética do performativo". ${ }^{3}$

Logo no prólogo de seu "O Teatro Pós-Dramático", Hans-Thies Lehmann ressalta a substituição de nossa percepção linear-sucessiva por uma simultânea e multifocal ${ }^{4}$. O resultado disso seria uma leitura (e criação) de textos e espetáculos teatrais ao mesmo tempo mais superficial e mais abrangente.

\footnotetext{
${ }^{1}$ SARRAZAC, Jean-Pierre. O Futuro do Drama. Campo das Letras - Editores, Porto, 2002. "L'avenir du drame" (Paris: Circé/ Poche, 1999)

${ }^{2}$ SARRAZAC, Jean-Pierre. idem.

3 "Prevalent aesthetic theories hardly address the performative turn in arts - even if they can still be applied to it in some respects. However, they are unable to grasp its key aspect - the transformation from a work of art into an event. To understand, analyze, and elucidate this shift requires a whole new set of aesthetic criteria, suited to describe the specific characteristics of performance- an aesthetics of the performative." FISCHER=LICHTE, Erika. The Transformative Power of Performance.

${ }^{4}$ LEHMANN, Hans-Thies, O Teatro Pós-Dramático. p. 17
} 
"A leitura lenta, mais profunda, assim como o teatro pormenorizado e vagaroso, perde seu estatus em face da ciruculação mais lucrativa de imagens em movimento. (...) Se na modernidade, segundo Roland Barthes, cada texto levanta o problema de sua possibilidade - sua linguagem alcança o real?-, a prática radical da encenação também problematiza o status de realidade aparente. (...) Um modo profundamente diferente de usar os signos teatrais justifica com plena razão que se descreve um setor considerável do novo teatro como 'pós-dramático'. Ao mesmo tempo, o novo texto teatral, que sempre reflete uma condição de estrutura linguística, é um texto teatral 'não mais dramático. "'5

Em que sentido esse "novo" status se diferencia daquele ocupado pelo texto no passado? Que novas relações entre dramaturgos, diretores e atores isso provoca? De que modo a abertura de um novo espaço de comunicação, em jogos eletrônicos e em mídias interativas e coletivas - e, portanto, uma modificação de nossa percepção de mundo - interfere na escrita dramática? Como essas formas rapsódicas transformam a estética teatral? Devido à diversidade da escrita contemporânea e à multiplicidade coexistente de "estéticas cênicas", responder a estas perguntas não parece ser tarefa fácil e nem a isso se pretende esta dissertação. Antes, parte-se destas perguntas para estruturar um pensamento teórico que sustente uma criação artística.

Josette Féral afirma que a riqueza da prática teatral contemporânea é justamente a diversidade, além da convicção, compartilhada por todos - autores, artistas, pesquisadores e espectadores - de que não há mais pólos isolados de criação, mas sim o encontro duas artes: a dramática e a cênica. Assim, qualquer estudo de textos contemporâneos deve também prever essa intersecção. A escrita não pode ser considerada isolada da cena, e a cena não pode ser examinada excluindo-se a escrita. ${ }^{6}$

Aqui vale então uma pequena digressão para darmos sequência ao raciocínio. Buscando definir os conceitos de performatividade e performance, a pesquisadora Erika Fischer-Lichte

\footnotetext{
${ }^{5}$ LEHMANN, Hans-Thies. Idem. p. 19.

6 "Nevertheless, the analysis of one cannot minimize its reflection on the other. The dramatic cannot be considered in isolation from the scenic, and the scenic cannot be examined in the absence of the dramatic, because this intersecting reflecting - from the director onto the text and from the author onto the theatrical performance - is the source of, on the one hand, performance style, and on the other, writing style." FÉRAL, Josette, "Moving Across Languages". Em: MOUNSEF, FERAL."The Transparency of the Text. 2007 - Yale Univerity.
} 
afirma que duas características definem a "performatividade": a primeira é que os pares dicotômicos como sujeito/objeto e significante/significado perdem suas polaridades e definições claras (já que uma vez colocados em movimento, eles começam a oscilar); a segunda é que o performativo se sustenta por sua habilidade em desestalizar e colapsar antagonismos binários. ${ }^{7}$ O primeiro destes antagonismos em colapso é a dupla "real e ficcional". Sabemos que a tensão entre realidade e ficção não é privilégio da "estética do performativo", mas de todo evento ou espetáculo teatral. É sempre em um espaço real que o espetáculo acontece, sempre em tempo real, com corpos reais em movimento. Ao mesmo tempo, esse espaço real pode significar vários e inúmeros espaços ficcionais; a duração do espetáculo não precisa corresponder ao tempo representado e, geralmente, o corpo real do ator representa um outro corpo - uma figura cênica ou um personagem. É por isso que Fischer-Lichte afirma que quando e onde quer que o teatro aconteça, ele é caracterizado por uma tensão entre realidade e ficção, entre o real e o ficcional. ${ }^{8}$ A realidade implícita em toda situação teatral sempre foi um amplo espaço de batalhas. A dicotomia entre esses dois pólos marcou toda a prática teatral do século XX: de um lado, a valorização do ficcional, nas tentativas de erradicar, a todo custo, qualquer vestígio de realidade em favor do ilusionismo - seja visando a representar figurativamente o real (naturalismo) ou o irreal (simbolismo)- e, de outro, o privilégio do "real" ao ficcional, ao revelar os procedimentos teatrais e se dirigir diretamente à platéia (como os estudos do teatro épico de Bertolt Brecht) ou ao inserir elementos do "evento" na cena (vanguardas das primeiras décadas do século passado).

De um lado, devemos considerar as tentativas de erradicação do "real" na cena e no texto teatral: segundo a teoria de um teatro ilusionista (cujo símbolo máximo ainda é a quarta parede, de Diderot), a percepção do espectador deveria alcançar apenas o personagem da ação dramática, em busca de uma identificação com ele. Qualquer elemento que atraísse a percepção do espectador para o real funcionaria como um agente perturbador da ilusão, já que ele será "forçado" a deixar o mundo da peça para habitar o mundo da real corporeidade. Para evitar isso é que Johann Jakob Engel, um filósofo iluminista, sugere aos atores que seus

\footnotetext{
${ }^{7}$ FISCHER-LICHTE, Erika. Explaining Concepts: Performativity and performance.

${ }^{8}$ FISCHER-LICHTE, Erika. Fictional Realities/Real Fictions
} 
corpos reais se escondam atrás de corpos ficcionais e condena as atrizes cujos corpos não significam apenas os corpos das personagens teatrais que representam. Vale lembrar que essa é a idéia subterrânea do teatro psicológico-realista. Peter Szondi, ao discorrer sobre o drama moderno (1880-1950), afirma que a idealização de um drama absoluto parte unicamente da "reprodução de relações intersubjetivas." Toda a estrutura do drama seria formulada, então, na esfera do diálogo, desligando-se (para que sua pureza dramática fosse mantida) de tudo o que Ihe fosse externo - o autor, o espectador ${ }^{9}$, o corpo do ator ${ }^{10}$ - em favor da criação de um "segundo mundo". Sabe-se que essa idéia de "drama absoluto" nunca chegou a ser completamente posta em prática, já que em toda e qualquer apresentação, um conflito surge entre o corpo semiótico e o corpo fenomenal, entre o real e o ficcional. Um universo inteiramente ficcional é uma abstração. Essa é uma duas razões pelas quais as vanguardas teatrais da primeiras décadas do século XX atacaram tão veementemente o teatro psicológicorealista.

Devemos, então, atentar para outro extremo - as tentativas de valorização do "real" introduzidas pelas vanguardas no início do século passado: já em 1913, em seu manifesto “O Teatro de Variedades", Marinetti sugeria que o acaso fosse introduzido no espetáculo, que os atores se movimentassem entre os espectadores e que a plateia fosse instigada a se revoltar e a participar. ${ }^{11}$ Mas é nos anos 60 que o foco da cena artística deixa de incidir na ficção e radicalmente passa a trabalhar na esfera do real (sem que a tensão entre esses "opostos" desaparecesse). A performance art tornou explícita a realidade com inúmeros casos de mutilações e torturas reais executadas diante dos espectadores, com a conversão do público em ator do espetáculo, seja por manifestação espontânea (como a famosa interrupção da performance Lips of Thomas, de Marina Abramovich, em uma galeria em Innsbruck) ou coagida (algumas da interações propostas pelo grupo FLUXUS); com a valorização da ação real e da

\footnotetext{
9 "A relação espectador-drama conhece somente a separação e a identidade perfeitas, mas não a invasão do rama pelo espectador ou a interpelação do espectador pelo drama." SZONDI, Peter. Teoria do Drama Moderno. p. 31.

10 "A relação ator-papel de modo algum deve ser visível; ao contrário, o ator e a personagem têm de unir-se, constituindo o homem dramático." Idem, p. 31.

11 "Introduce surprise and the need to move among the spectator o the orchestra, boxes, and balcony. Some random suggestions: spread a powerful glue on some of the seats, so that the male or female spectator will stay glued down and make everyone laugh...-Sell the same ticket to ten people: traffic jam, bickering and wrangling." (conforme citação de Fischer-Lichte, em Fictional Realites/Real Fictions)
} 
presença corporal do performer , fundida com a própria obra-de-arte. Não foi só a performance art, entretanto, que evidenciou o caráter real em detrimento do ficcional, mas também os artistas teatrais, como Jerzy Grotowski. Assumindo elementos performáticos, como a extirpação da figura dramática - o personagem - e colocando em primeiro plano o fato de que os atores estavam realizando ações reais em espaço e tempo reais, Grotowski reverteu a relação entre o ator e o personagem. Ele definiu o personagem ficcional como um instrumento para se alcançar uma "meta", e não como o objetivo final dos esforços do ator. O ator, para ele, usa o personagem para se dissecar e aí se concretiza a idéia de um "ator santo". Mesmo nesses casos, entretanto, o "real" puro também é uma abstração, já que a representação nunca deixa de existir. Se tomarmos como exemplo a já citada performance de Marina Abramovich, Lips of Thomas $^{12}$ : embora o entendimento das ações da artista fosse menos importante do que a experiência real, isso não significa dizer que não havia nada para o público/visitante da instalação interpretar: os objetos usados e as ações realizadas por ela podiam (e podem) construir múltiplos significados. A cruz desenhada no abdômem de Abramovich poderia fazer sugerir as mais diversas associações místicas, religiosas, culturais, políticas (sendo o símbolo da loguslávia socialista). ${ }^{13}$

Portanto, estando o espetáculo inevitalmente ligado à materialidade (seja do palco, da presença de atores em carne e osso ou da efemeridade temporal) e à produção de significados, não há como excluir nenhum dos dois vetores da tensão entre realidade e ficção implícita à situação teatral. Entre esses dois limites impossíveis há uma grande possibilidade de transgressões e hibridismos, já que as fronteiras entre os dois conceitos não são claramente desenhadas mas, ao contrário, sempre borradas. E é neste lugar - "um espaço de

\footnotetext{
${ }^{12}$ Nesta performance, Abramovich ficava nua e, após comer grandes quantidades de mel, tomar uma garra garrafa de vinho, ela quebrava uma taça com sua mão direita, ferindo-se e continuava a se torturar desenhando em sua barriga, com uma gilete, uma estrela de cinco pontas e deitando-se sobre um grande bloco de gelo. Alguns espectadores interferam na performance, retirando-a do processo torturante.

${ }^{13}$ FISCHER-LICHTE, Erika. The Transformative Power of Performance. p. 16.
} 
deslocamentos e superposições de camadas ficcionais e reais", ${ }^{14}$ que se localizam algumas das transformações recentes da cena contemporânea.

Com a dramaturgia não é diferente, já que não pode mais ser dissociada da cena. Esse mesmo hibridismo entre realidade e ficção aparece na dramaturgia pelo confronto entre o discurso e a voz do ator. Nesse entre-lugar, o texto teatral é deposto do trono que ocupa desde o meio de século $X^{15}{ }^{15}$, isto é, perde sua função como um valioso regulador da representação e torna-se um dos muitos discursos que compõem a cena. As pesquisadoras Donia Mounsef e Josette Féral afirmam que, além dessa tensão entre realidade e fiç̧ão, dois outros fatores contribuíram para esta queda: a impossibilidade de representar o sujeito e o descrédito na capacidade da linguagem em transmitir significados. ${ }^{16}$

A despeito da variedade de temas, percebe-se uma escrita dramática a partir da década de 1980, principalmente na França, em que é recorrente esta já descrita impossibilidade de representar o real.

\begin{abstract}
"Preso entre a necessidade de contar uma história e ao ceticismo da linguagem, entre os caprichos do diretor e os impulsos da ação, os textos de palco tornaram-se o terreno de batalha de linguagem, vida, e perfomance. Fragmentada e fragmentária, no todo ou em partes, composta por montagens, colagens, vestígios verbais, palavras tímidas, a dramaturgia passa a significar de forma diversa $e$ ambígua. Peças contemporâneas são frequentemente sujeitas à desagregação do diálogo, à fragmentação narrativa, à ação dramática descontínua e a uma fragmentada progressão de eventos. Contribuindo com esta fragmentação, está o fato de que o teatro toma emprestado de outros gêneros (romance, cinema, televisão, e assim por diante), convidando o diretor, o ator e o espectador a sair do estritamente textual e a entrar no domínio do performativo. (...) Estas formas de escrita muitas vezes combinam o verbal, o vocal e a pantomima, usando o palco para produzir sua expressão mais forte. Elas ressoam no corpo do ator e no espaço de representação, naquele espaço difuso e transitório entre o eu eo outro, o uno e o
\end{abstract}

\footnotetext{
${ }^{14}$ Expressão usada por Sílvia Fernandes para descrever a dramaturgia do espetáculo BR3, do Teatro da Vertigem. Cartografia de BR3 - p. 45.

${ }^{15}$ MOUNSEF, FÉRAL. The Transparency of the Text, Em Editor's Preface.

16 "Three major factors contributed to this fall: the suspicion of theater's capacity to express the real, the impossibility of representing the subject, and the fundamental distrust in language's ability to convey meaning." MOUNSEF, Donia; FÉRAL, Josette, idem.
} 
múltiplo, o indivíduo e a cidade, a interface do que é dito e como é vivido $^{17}$

Analisar aquelas transformações cênicas é imprescindível para compreender também estas mudanças na escrita dramática. Essa análise deve trafegar pelos diversos campos da operação teatral; teoria e prática, dramaturgia e reflexão teórica não são mais pólos estanques de conhecimentos, mas partes congruentes. Separar a prática dramatúrgica do processo de criação da cena seria sustentar uma lacuna de cultura contemporânea caracterizada pela disjunção entre um empirismo sem pensamento e um pensamento sem experiência ${ }^{18}$.

Assim, esta dissertação procura entender a dramaturgia "escrita no presente" ligada à prática teatral. Para tanto, utiliza conceitos relacionados a mídias de comunicação interativa e coletiva (navegação, hiperdocumentos e hipermídias, imersão, agência ${ }^{19}$ ) como ferramentas de análise e de proposição em um processo de criação dramatúrgica: um diagrama de peças potenciais que resultou no espetáculo "Escuro", dirigido e escrito por mim.

Em síntese, acompanha-se o processo de criação do espetáculo, analisando-o através do transporte metafórico de conceitos propostos por Janet $\mathrm{H}$. Murray ao descrever narrativas em ambiente virtual (imersão, agência e autoria procedimental) e comparando-o a outros dramaturgos contemporâneos que serviram de modelo à criação (as excursões à linguagem cotidiana e as paisagens do francês Michel Vinaver; o texto híbrido, que transita entre a realidade e o lirismo, do argentino Federico Léon; os registros cênicos de Simon McBurney).

\footnotetext{
${ }^{17}$ Tradução livre a partir de "Caught between the need to tell a story and the skepticism of language, between the whims of the director and the impulses of acting, stage texts have become the embattled ground of language, liveness, and performance. Fragmented and fragmentary, in a whole or in pieces, made up of montage, collage verbal remains, diffident words, the theatrical text seems to signify in diverse and ambiguous ways. Contemporary plays are often subject to the breakdown of dialogue, narrative fragmentation, splintered dramatic action, and a fractured progression of events. Contributing to this fragmentation is the fact that theater borrows from other genres (novel, film, television, and so on), inviting the director, the actor, and the spectator to journey outside the strictly textual into the domain of the performative. (...) These forms of writing often combine the verbal, the vocal, and the pantomimic, calling upon the stage to give them their strongest expression.. They resonate in the body of the actor and in the space of representation, in that insterstitial and transient space between the self and other, the one and the multiple, the individual and the city, at the interface of what is said and how it's lived.". (MOUNSEF, FERAL. 2007: 03)

${ }^{18}$ REWALD, Rubens. Caos/Dramaturgia. São Paulo, Perspectiva, 2005.

${ }^{19}$ Ver Pierre Lèvy - Cibercultura , e outras obras do mesmo autor como $O$ que é Virtual?
} 


\section{Conduzindo à deriva em meio ao dilúvio}

Jorge Luís Borges, em "O Jardim das Veredas que se Bifurcam" ${ }^{20}$, nos conta a história de Ts'ui Pen, que havia abandonado a vida pública para se dedicar à construção de dois grandes projetos: escrever um livro e construir um labirinto. O livro fora desprezado por seu caráter ilógico; já o labirinto nunca chegou a ser construído. Séculos depois, descobre-se que o livro era o próprio labirinto. Nele, cada história permitiria inúmeros desenlaces. Cada vez que um homem se defronta com diversas alternativas, opta por uma e elimina as outras; no romancelabirinto de Ts'ui Pen, os personagens optam, simultaneamente, por todas. Criam-se, assim, diversos tempos que se proliferam e se bifurcam. A trama não possui apenas uma história, mas todas as histórias possíveis. Os caminhos não-escolhidos não são apagados da memória do sistema, ao contrário, continuam vivos, esperando a sua vez de entrar no jogo arquitetado por Ts'ui Pen.

Essa estrutura rizomática ${ }^{21}$ concebida por Borges corresponde ao tipo de narrativa que encontramos hoje, com a abertura de um novo espaço de comunicação, em jogos eletrônicos e em mídias interativas e coletivas. No primeiro caso, embora o jogador conduza seu personagem (avatar) linearmente por uma das diversas narrativas em potência a estrutura do jogo é bem mais complexa e comporta múltiplas e entrecruzadas possibilidades. No segundo caso, o contato com as informações de diversas naturezas também é feito de forma a privilegiar a conexão e a horizontalidade. Cada página em um site, por exemplo, pode nos conectar a inúmeras outras páginas e essas a outras e a outras, numa teia de links tão infinita como o romance de Ts'ui Pen. Em ambos os casos, substitui-se a figura do leitor pela do navegador.

O filósofo francês Pierre Lèvy acredita que navegação parece ser uma expressão muito apropriada para essa rede virtual que hoje sustenta nossas formas de cognição e comunicação em que estamos mergulhados. Segundo ele:

\footnotetext{
${ }^{20}$ BORGES, Jorge Luís. Ficções, p. 110.

${ }^{21}$ DELEUZE, Gilles. GUATTARI, Félix. Mil Platôs, Vol. 1. Com o conceito de rizoma, Deleuze e Guattari descrevem filosoficamente um esquema abstrato entendido, neste projeto, como uma rede aberta e horizontal de narrativas e a proliferação, sem limites a priori, de conexões entre seus nós associada uma multiplicidade móvel de centros.
} 
"Roy Ascott, um dos pioneiros e principais teóricos da arte em rede, fala de um segundo dilúvio, o das informações, gerado por conta de sua natureza exponencial, explosiva e caótica. A densidade dos links entre as informações aumenta vertiginosamente nos bancos de dados, nos hipertextos e nas redes. Os contatos transversais entre os indivíduos proliferam de forma anárquica. É o transbordamento das informações, a inundação de dados, as águas tumultuosas da comunicação por onde navegamos. ${ }^{22}$

A partir de conceitos como hipertextualidade, imersão e agenciamento - presentes tanto em jogos eletrônicos como em ambientes virtuais de memória coletiva - apresento duas abordagens: uma reflexiva, lançando um breve olhar sobre fragmentos de textos teatrais de dramaturgos contemporâneos; e outra criativa, através de uma análise do processo de criação da mapa dramatúrgico "Escuro".

A escolha do meio digital como ponte metafórica para a análise acontece pela correspondência poética entre algumas das características de leitura e criação nesse ambiente e as proposições da criação aqui discutida. Não é, portanto, a tentativa de criar uma nova terminologia de análise. Antes, é um ponto de vista bastante específico na abordagem de uma dramaturgia criada simultaneamente à prática e pesquisa aqui descritas. Não se trata, é claro, de um exercício de interdisciplinaridade entre tecnologia e dramaturgia. É uma proposta de mudança de percepção do objeto analisado, no caso o texto teatral. Este, deixando de ser estável, pode se adequar a metodologias de análise e compreensão que dêem conta de sua instabilidade. Metodologias essas que, por sua vez, à medida que organizam novos paradigmas, nos levam a procurar instabilidades e a perceber como instável o que até pouco tempo percebíamos como estável.

Neste ponto, é definido um paralelo fundamental às análises que se seguirão e à criação do espetáculo "Escuro": o texto é visto como um hipertexto ${ }^{23}$ teatral.

\footnotetext{
${ }^{22}$ LEVY, Pierre. CiberCultura, São Paulo, Editora 34.

${ }^{23}$ Segundo Carlos Irineu da Costa : "Hipertexto - Uma forma não linear de apresentar e consultar informações. Um hipertexto vincula as informações contidas em seus documentos (ou 'hiperdocumentos', como preferem alguns) criando uma rede de associações complexas através de hiperlinks, ou mais simplesmente, links."
} 
A abordagem mais simples desse conceito é, em oposição a um texto linear, descrevê-lo como um texto estruturado em rede. O hipertexto é constituído por nós e por links entre esses nós indicando a passagem de um nó para outro. A título de exemplificação, poderíamos dizer que, em princípio, percorremos um romance da primeira à última linha, mas lidamos de forma bastante distinta quando se trata de uma enciclopédia. Podemos consultá-la de inúmeras formas: através do sumário ou do índice remissivo, aleatoriamente, alfabeticamente ou linearmente. "Navegamos" por ele usando suas ferramentas de orientação (léxicos, índice, tabelas e tópicos), de acordo com os assuntos de nosso interesse, recolhendo informações de forma pessoal e única. Um hipertexto dramático surgiria, então, como um mapa virtual, fonte indefinida de atualizações ${ }^{24}$ : móvel, caleidoscópico, que apresenta suas facetas, gira, dobra-se e desdobra-se em inúmeras leituras.

Torna-se evidente aqui a mistura das funções de leitura e escrita. Definindo o hipertexto como um espaço de percursos para leituras e agenciamentos possíveis, um texto aparece como uma leitura particular de um hipertexto, como o caminho de links e nós percorrido pelo navegador. Como nos videogames, a narrativa vivenciada (ou assistida) é uma atualização das inúmeras narrativas virtuais presentes em sua estrutura. O navegador participa, portanto, da redação da peça que "lê".

Em outras palavras, no caso do texto teatral "Escuro", o que o dramaturgo de fato escreve é uma matriz de textos potenciais. É, então, função dos navegantes (diretores, atores, espectadores) "participarem" da estruturação de alguns desses textos, colocando em jogo as diversas combinatórias entre os nós.

Para sintetizar de forma oportuna e clara a idéia aqui levantada, vale ainda citar Pierre Lèvy:

"A escrita e a leitura trocam seus papéis. Aquele que participa da estruturação de um hipertexto, do traçado pontilhado das possíveis dobras do sentido, já é um leitor. Simetricamente, aquele que atualiza um percurso, ou manifesta determinado aspecto da reserva documental, contruibui para a redação, finaliza temporariamente uma

\footnotetext{
${ }^{24}$ LÈVY, Pierre. O que é virtual?.
} 
escrita interminável. Os cortes e remissões, os caminhos de sentidos originais que o leitor inventa podem ser incorporados à própria estrutura dos corpus. Com o hipertexto, toda leitura é uma escrita potencial." 25

É importante mais uma vez ressaltar que o diálogo aqui proposto entre dois campos distintos do conhecimento (dramaturgia e tecnologias interativas) requer um partido específico, uma abordagem limitada, para se evitar um texto repleto de generalidades, onde não se aprofundam questões em nenhum dos dois campos. Nesse sentido, opta-se por utilizar os conceitos ligados às tecnologias interativas como metáforas para o estudo e criação de dramaturgia. Efetua-se o transporte de um contexto a outro, aproximando dois conceitos distintos e contextualizando-os num mesmo domínio. A manipulação desses conceitos cria um amplo caminho para a reflexão e elaboração de um texto teatral. No entanto, tais conceitos não são aprofundados em todas as suas dimensões, sendo que somente alguns de seus aspectos conceituais interessam à pesquisa.

Poder-se-ia pensar, a partir do que foi exposto, que o transporte entre conceitos da "cibercultura"e dramaturgia seria o ponto central do trabalho. Porém, é fundamental esclarecer que o objetivo nunca foi encontrar uma ponte entre esses campos. Antes, pretendese reunir em um mesmo sistema conceitos diversos que beneficiem uma criação.

A criação deste mapa dramatúrgico foi o centro de toda essa pesquisa. Esse sistema em que termos de internet e teatralidade constituem um mesmo domínio - serviu apenas como instrumento de análise de fragmentos de peças contemporâneas e, mais importante, força motora do processo criativo da dramaturgia e da cena.

Mais do que propor uma nova forma de escrever e analisar dramaturgias, essa dissertação e a criação do texto dramático aqui apresentado abrem portas para o desenvolvimento de uma futura pesquisa estruturada sobre "dramaturgia procedimental", isto é, a hiperficção num contexto dramatúrgico. Um hipertexto dramático seria como um texto virtual, fonte indefinida de atualizações. Embora toda a literatura dramática possa ser considerada como uma virtualidade (já que existe apenas em potência, não em ato; o campo de

\footnotetext{
${ }^{25}$ Pierre Lèvy. Cibercultura. p. 61
} 
forças e problemas do texto dramático só se resolvem em uma atualização cênica, também pessoal e única), uma "hiperdramaturgia" pressupõe uma história multiforme ${ }^{26}$ em que "tempo presente" possa modificar a estrutura da cena, isto é, determinar a escrita dramatúrgica da peça que se "vê". O desejo dessa pesquisa contínua é, então, pensar uma literatura dramática em que o "leitor" poderá criar os caminhos a serem seguidos e não poderá mais deixar a ficção sem modificá-la ou sem que seja modificado por sua experiência imersiva.

Por fim, vale uma consideração acerca do corpo dessa dissertação:

A primeira parte trata do ambiente digital a partir principalmente das teorias de Janet $\mathrm{H}$. Murray. A idéia é apontar terminologias particulares e descrever as principais características do ambiente digital, conceitos esses que serão utilizados como instrumentos de análise e metáforas para se falar de criação dramatúrgica.

Na segunda parte, concretizo o transporte entre teatro e meio digital através de breves análises de fragmentos de dramaturgias contemporâneas que serviram de modelo à criação de "Escuro". Particularmente me debruço sobre o formato de publicação de uma das peças do Theatre de Complicitè, fragmentos da obra de Michel Vinaver e do argentino Federico Léon.

Chegamos a um terceiro momento e centro do trabalho - quando, ao invés de utilizar conceitos propostos pela pesquisadora Janet H. Murray (imersão, agência, autoria procedimental) como ferramentas de leitura e análise, passo a utilizá-los como ferramentas de proposição, ou seja, de escrita. Unindo a teoria apresentada até esse momento à experimentação prática, definem-se conceitos e descreve-se o processo criativo do espetáculo "Escuro". A pesquisa abrange não só a análise do texto teatral, mas também a análise de sua construção. Não se trata, é claro, da documentação de um espetáculo em fase de preparação, mas de uma reflexão teórica sobre um processo de criação.

\footnotetext{
26 "Estou usando o termo história multiforme para descrever uma narrativa escrita ou dramatizada que apresenta uma única situação ou enredo em múltiplas versões - versões estas que seriam mutuamente excludentes em nossa experiência cotidiana." (MURRAY, 2003: 64)
} 
Por fim, apresento o mapa dramatúrgico - por se tratar de um hipertexto dramático, a melhor representação de suas possibilidades é um diagrama - criado em processo com a colaboração de dez atores e um possível agenciamento, isto é, uma possível organização e cruzamento dramatúrgico das redes criadas. Esse agenciamento foi apresentado como um espetáculo, com estreia em novembro de 2009 na cidade de São Paulo. 


\section{PARTE I - O AMBIENTE DIGITAL:}

DEFINIÇÕES

\section{Breve passeio pelo bosque da hiperficção}

Em "Seis Passeios pelos Bosques da Fiç̧ão", Umberto Eco utiliza a palavra "bosque" como metáfora para qualquer texto narrativo. Um bosque é um jardim de caminhos que se bifurcam (BORGES, 1989). Mesmo quando não existem no bosque trilhas bem definidas, todos podem traçar sua própria trilha, decidindo ir para a esquerda ou para a direita de determinada árvore e, a cada árvore que encontrar, optando por esta ou aquela direção.

"Num texto narrativo, o leitor é obrigado a optar o tempo todo. Na verdade, essa obrigação de optar existe até mesmo no nível da frase individual - pelo menos sempre que esta contém um verbo transitivo. Quando a pessoa que fala está prestes a concluir uma frase, nós como leitores ou ouvintes fazemos uma aposta (embora inconscientemente): prevemos sua escolha ou nos perguntamos qual será sua escolha. ${ }^{\prime 27}$

Porém, com as (nem tão recentes) estruturas de linguagem surgidas com os dispositos comuniciacionais (LÈVY, 1999), tecnologias de informação coletivas, jogos eletrônicos e ambientes digitais, as trilhas dos bosques ficcionais e as possibilidades de percorrê-los aumentaram vertiginosamente, extrapolando o campo da subjetividade do leitor-empírico e alcançando a própria estrutura do bosque. Mais do que ser leitor, percorrer este novo bosque -

${ }^{27}$ ECO, Umberto. Seis Passeios Pelo Bosque da Ficção.1991. p. 12. Eco afirma ainda que há duas maneiras de percorrer um bosque.

"A primeira é experimentar um ou vários caminhos (a fim de sair do bosque o mais depressa possível, digamos, ou de chegar à casa da avó, do Pequeno Polegar ou de Joãozinho e Maria); a segunda é andar para ver como é o bosque e descobrir por que algumas trilhas são acessíveis e outras não. Há igualmente duas maneiras de percorrer um texto narrativo. Todo texto desse tipo se dirige sobretudo a um leitor-modelo do primeiro nível, que quer saber muito bem como a história termina (se Ahab conseguirá capturar a baleia e se Leopold Bloom encontrará Stephen Dedalus depois de cruzar com ele algumas vezes no dia 16 de junho de 1904). Mas também todo texto se dirige a um leitor-modelo de segundo nível, que se pergunta que tipo de leitor a história deseja que ele se torne e que quer descobrir precisamente como o autor-modelo faz para guiar o leitor." (ECO, 1991:33) 
um jardim que procura representar a vida enquanto composição de possibilidades paralelas implica descobrir caminhos inéditos, inventar novas árvores, desenhar novas trilhas, mergulhar e navegar em seus lagos.

"Para dar conta da nova inscrição social dos sujeitos e dos sentidos, faz-se necessária a acuidade de observar a textualidade eletrônica a partir de uma outra ordem de leis, diferente daquela que rege o impresso e que dita os mecanismos de coesão, coerência, unidade, gênero textual etc. Isso porque se é verdade que, na folha de papel em branco, existe uma delimitação para o dizer e um recorte do espaço físico a ser preenchido, também é válido afirmar que a página com o hipertexto, teoricamente, comporta inúmeras outras páginas, entradas e/ou saídas para/de um dizer, rompenao com toda ordem de limitação física do papel, visto que ele triplica-se em vários papéis. (...)... não é possivel ter noção de inteireza, unidade e completude, não há meios de sobrevoar toda a área para um reconhecimento geral, não existe a possibilidade de executar uma ação tão familiar quanto folhear um livro todo, percorrendo com o dedo o seu dorso, folha de rosto, capa, rodapé etc. Não há nada além do recorte da janela, atrás da qual está a rede inteira, escondida e submersa na opacidade $e$ extensão desconhecida. Vê-se uma página de cada vez, sem saber ao certo qual é o fio que a prende a um livro inteiro e talvez nem mesmo livros inteiros existam mais... Quanto ao navegador, resta-lhe o prazer de provar os pedaços sem a dimensão do todo, de experimentar as margens sem reconhecer o centro, de andar sobre fios imaginários sem o apoio das vias reais do papel e, enfim, de equilibrar-se nos desvãos dos nós e pontos de uma rede que não vê a urdidura. ${ }^{28}$

Este novo modo de percorrer o bosque ficcional faz surgirem histórias multiformes, narrativas fragmentárias em que cada "leitor" vai reordenar a fábula para si mesmo, fiç̧ões com tendência a se complexificarem - em números de links e alternativas de navegação - a cada nova "leitura".

\footnotetext{
${ }^{28}$ ROMÃO, Lucília Maria Sousa; ROMÃO, Aquilau Moreira. "Do pergaminho à tela do computador: a trajetória do livro." pp. 98-99
} 


\title{
Hipertexto
}

Vannevar Bush supõe que esse novo modo de contar histórias talvez carregue uma linguagem mais coerente com a complexa organização de nosso pensamento ${ }^{29}$, já que pretende

"... dar uma existência simultânea a outras possibilidades, permitindonos ter em mente, ao mesmo tempo, múltiplas e contraditórias alternativas. Seja a história de múltiplas formas um reflexo da física pós-einsteiniana, ou de uma sociedade secular assombrada pela imprevisibilidade da vida, ou de uma nova sofisticação do modo de conceber a narração, suas versões alternadas da realidade são hoje parte do nosso modo de pensar, parte da forma como experimentamos o mundo." 30

Tradicionalmente, Vannevar Bush é considerado o pioneiro na proposição de uma estrutura textual que se propõe a registrar o mundo sob essa nova perspectiva. Em seu famoso artigo "As we may think"31 , Bush imagina a criação de uma máquina - o "memex" para o armazenamento e manipulação de informações (e da memória) de forma não-seqüencial. Assim ele a descreve:

\begin{abstract}
"Considere-se um dispositivo futuro para uso individual, que é uma espécie de arquivo privado mecanizado e uma biblioteca. Ele precisa de um nome, e, ao acaso, escolhe-se "memex". Um memex é um dispositivo no qual um indivíduo armazena todos seus livros, registros e comunicações, e que é mecanizado, para que possa ser consultado com extrema velocidade e flexibilidade. É um suplemento ampliado intimo de sua memória. ${ }^{132}$
\end{abstract}

No entanto, foi Ted Nelson o primeiro a chamar de hipertextos esses textos nãoseqüenciais, com acesso multisseqüencial e de conteúdo enciclopédico. Um hipertexto é, pois, descrito como um texto (entendido aqui como palavras, imagens, memórias) não-linear,

\footnotetext{
${ }^{29}$ BUSH, Vannevar. "As We may think", acessado em 07 de julho de 2008 http://www.theatlantic.com/doc/194507/bush

${ }^{30}$ MURRAY, Janet. Hamlet no Holodeck. p. 49.

${ }^{31}$ http://www.theatlantic.com/doc/194507/bush

32 http://www.theatlantic.com/doc/194507/bush/4

Tradução livre a partir de: "Consider a future device for individual use, which is a sort of mechanized private file and library. It needs a name, and, to coin one at random, "memex" will do. A memex is a device in which an individual stores all his books, records, and communications, and which is mechanized so that it may be consulted with exceeding speed and flexibility. It is an enlarged intimate supplement to his memory."(BUSH, 1945:4)
} 
interativo, cuja navegação é vinculada, o acesso é randômico e que promove a articulação entre diferentes linguagens. ${ }^{33}$ Segundo Luiz Antônio Marcuschi:

"O termo hipertexto foi cunhado por Theodor Holm Nelson em 1964, para refletir uma estrutura eletrônica não-sequencial e não-linear, que se bifurca e permite ao leitor o acesso a um número praticamente ilimitado de outros textos a partir de escolhas locais e sucessivas, em tempo real. Assim o leitor tem condições de definir interativamente o fluxo de sua leitura a partir de assuntos tratados no texto sem se prender a uma sequência fixa ou a tópicos estabelecidos por um autor. Trata-se de uma forma de estruturação textual que faz do leitor simultaneamente co-autor do texto final. O hipertexto se caracteriza, pois, como um processo de escrita/leitura eletrônica multilinearizado, multissequencial e indeterminado, realizado em um novo espaço., ${ }^{34}$

Dito de outra forma, trata-se de um mapa textual que pode ser lido de qualquer ponto; cada leitura pode criar um texto diferente.

Neste ponto, estabelece-se um primeiro paralelo proposto pelo trabalho: o texto teatral é observado como um hipertexto, um rizoma textual. A escritura, ao perder sua supremacia num contexto que Hans-Thies Lehmann classifica como "pós-dramático", perde também sua síntese, fragmenta-se em episódios, situações (LEHMANN, 2007:31). A dramaturgia, mais do que nos conduzir por um enredo linear, tem uma nova missão -

\footnotetext{
"reinventar a linguagem, explorar sua linhas de falha, em outras palavras, fundir escrita e performance. ${ }^{, 35}$
}

O enredo não é mais o fundamento de um espetáculo, antes é uma matriz geradora de possíveis espetáculos que pode ser organizada e reorganizada por todos os elementos cênicos, agora des-hierarquizados. (LEHMANN, 2007: 145).

Esse tipo de organização já foi bastante discutido pela teoria literária pós-estruturalista. Tais dramaturgias são comumente associadas ao conceito de "rizoma" do filósofo Gilles

\footnotetext{
${ }^{33}$ Nelson afirma ainda que um hipertexto é caracterizado pela ausência de um suporte físico, enquanto a hipermídia, para ele, vincula-se ao poder do computador de estocar, rever e apresentar informações na forma de imagens, textos, animações e sons.

${ }^{34}$ MARCUSCHI, L. A. Linearização, cognição e referência: o desafio do hipertexto. In: Línguas e Instrumentos Linguísticos. 3, Campinas: Editora Pontes, 1999. p. 21-22

${ }^{35}$ MOUNSEF, FERAL, The Transparency of the Text, 2007. p. 3
} 
Deleuze, um sistema de raízes tuberculares no qual qualquer ponto pode estar conectado a qualquer outro. $^{36}$ Deleuze utilizou o sistema de raízes do rizoma como um modelo de conectividade nos sistemas de ideias; os críticos aplicaram esse conceito a sistemas de textos alusivos não lineares. A tradição pós-moderna do hipertexto, então, celebra o texto indeterminado como uma liberação da tirania do autor e uma afirmação da liberdade interpretativa do leitor.

O paralelo evidente é que tal estrutura rizomática (que nos faz evidentemente lembrar novamente do conto "O Jardim das Veredas que se Bifurcam", de Jorge Luís Borges ${ }^{37}$ ) corresponde ao tipo de narrativa que encontramos hoje em games e na internet. No caso dos games, embora o jogador conduza seu avatar linearmente por uma das diversas narrativas em potência, a estrutura do jogo comporta múltiplas e entrecruzadas possibilidades. Nos jogos de personagem, o jogador "age" como personagem e suas escolhas determinam, entre vários fios narrativos, aquele a ser seguido. Já em jogos de simulação, embora o jogador funcione como um controlador do sistema, a narrativa que se constrói é, também, determinada por suas ações e construída a partir de um rizoma de possibilidades.

No caso da internet, as narrativas se estruturam de forma a privilegiar o "inter-ser", a conexão e a horizontalidade, admitindo a interrupção e a reorientação do fluxo informacional em tempo real ou implicando na participação do usuário.

\section{Imersão e Agência}

A implicância desta participação amplia a noção do bosque (isto é, um texto narrativo) para um lugar de mergulho e integração do leitor à ficção, ancorando-se no prazer produzido pela experiência de ser transportado a um lugar de simulação - independentemente do conteúdo do fantasia (MURRAY, 2003: 102).

\footnotetext{
${ }^{36}$ DELEUZE, Gilles. Mil Platôs.

${ }^{37}$ BORGES, J orge L. Ficções. São Paulo, Globo, 1989.
} 
A autora de Hamlet no Holodeck afirma que os ambientes digitais são procedimentais, participativos, espaciais e enciclopédicos. ${ }^{38}$. Isso implica dizer, de uma forma vaga, que as narrativas produzidas neste ou para este ambiente são também interativas e imersivas. É verdade que os conceitos de imersão e interatividade estão quase intrinsecamente vinculados e não seria exagero dizer, de forma pedagógica, que, a partir destes dois conceitos, as ficções que se utilizam da hipermídia (seja como linguagem ou como suporte técnico) criam novas camadas metafóricas e ampliam suas possibilidades formais exponencialmente.

J. H. Murray assim refere-se à imersão - ou seja, a possibilidade oferecida pela hiperficção de que o leitor "entre" na narrativa e perca-se "quixotescamente" em seus bosques:

\begin{abstract}
"Imersão é um termo metafórico derivado da experiência física de estar submerso na água. Buscamos de uma experiência psicologicamente imersiva a mesma impressão que obtemos num mergulho no oceano ou numa piscina: a sensação de estarmos envolvidos por uma realidade completamente estranha, tão diferente quanto a água e o ar, que se apodera de toda a nossa atenção, de todo o nosso sistema sensorial. Gostamos de sair do nosso mundo familiar, do sentido de vigilância que advém de estarmos nesse lugar novo, e do deleite de aprendermos a nos movimentar dentro dele. A imersão pode requerer um simples inundar da mente com sensações (...) Muitas pessoas ouvem música dessa maneira, como um aprazível afogamento das partes verbais do cérebro. Mas num meio participativo, a imersão implica aprender a nadar, a fazer as coisas que o novo ambiente torna possiveis." 39
\end{abstract}

Esse novo bosque - com a proliferação de suas trilhas (links) e de fronteiras "mais reais que a realidade" - mostra-se como o ambiente propício para que o "leitor" faça parte da ficção e seja parte integrante da narrativa, já que são ao mesmo tempo espaciais (a capacidade de representar espaços navegáveis, geografias em tempo presente) e enciclopédicos (potencial artístico de representar o mundo de um modo mais abrangente e também mais particular). Assim, os leitores de uma narrativa imersiva compartilham espaços e regras ficcionais.

\footnotetext{
${ }^{38}$ MURRAY, 2003: 78

${ }^{39}$ MURRAY, 2003: 102
} 
"Compartilhar um ambiente de fantasia improvisado com outras pessoas envolve uma negociação constante do enredo e também dos limites entre a ilusão consensual e o mundo real.",40

Aqui, já podemos traçar um segundo paralelo importante a este trabalho. Torna-se relevante, no universo imersivo proposto pelo meio digital, a tensão entre realidade e ficção, também presente nas manifestações teatrais contemporâneas. É bastante comum encontrarmos narrativas criadas em computador que extrapolem a camada ficcional ao incluir a "realidade" do leitor em seu contexto, testando ao limite a durabilidade da ilusão. Murray nos dá dois exemplos:

\begin{abstract}
"Na instalação narrativa experimental Archeology of a Mother Tongue (Arqueologia de uma Língua Materna), produzida para o Banff Center fot the Arts em 1993, por Toni Dove e Michael Mackenzie, uma transição narrativa crucial toma a forma de uma pane no sistema, que simula uma queda de energia na cidade virtual representada pela interface surreal. Os interatores precisam apertar o botão 'reiniciar' em sua tela para prosseguir e, então, encontar a ciade alterada como se tivesse sofrido uma perda de memória. Mesmo em narrativas menos ambiciosas em termos artísticos oferecem efeitos semelhantes. Quando meu filho deixa de lado o controlador do jogo e faz uma pausa na ação do jogo Escape from Mars (Fuga de Marte, o Diabo da Tasmânia que ele estava controlando não tem sua imagem congelada. Ele olha fixamente para fora da tela e começa a bater o pé e acenar com impaciência. Esse simpático gesto cômico enfatiza a fronteira entre o boneco controlado pelo jogador e o personagem do roteiro. $\dot{E}$ quase como se o programador dentro do sistema estivesse acenando para nós, mas fazendo isso de um modo que reforça o mundo imersivo ao invés de rompê-lo". 41
\end{abstract}

Estes exemplos servirão de modelo, mais tarde, ao analisarmos de que forma a tensão entre os pólos de realidade e representação, ou ainda diálogo e narrativa, se apresentam na escritura de Escuro. É preciso dizer, porém, que narrativas imersivas carregam alguns problemas inerentes à sua estrutura, já que com os limites entre realidade e ficção são borrados, penetrar no mundo virtual sem rompê-lo é tarefa delicada. Mecanismos de organização para estruturar a participação do leitor podem ser alternativas para driblar estas

\footnotetext{
${ }^{40}$ MURRAY, 2003: 117

${ }^{41}$ MURRAY, 2003: 107
} 
questões. Assim, estruturar a participação (num site ou em um espetáculo interativo) como uma visita ou fornecer ao leitor um avatar (máscara) funcional, ao mesmo que tempo que limitam a participação ativa, garantem que a coerência e unidade do bosque ficcional sejam mantidas.

Além de imersivas, essas novas narrativas são também procedimentais e participativas. Procedimentais porque estruturam-se como uma série de regras a serem executadas pelo leitor. Só quando domina as regras de leitura, o leitor pode penetrar no bosque e decidir que trilhas seguir. Em games, costuma-se dizer que quanto mais rápida a curva de aprendizado, mais eficaz será o envolvimento com a narrativa do jogo. ${ }^{42}$

Logo, a própria linguagem da hiperfiç̧ão comporta procedimentos que organizam a participação do público. E quanto mais rápido o aprendizado, maior será a possibilidade de participação. Essas características definem as narrativas hipertextuais, então, como interativas.

Jesus de Paula Assis, em "Artes do Videogame", diz que interatividade é uma palavra que admite muitas acepções e assim ele a descreve:

"Existe uma interatividade trivial, apresentada por todo objeto que nos cerca (outras pessoas inclusive) e que reage a nossas ações. No pólo mais distante, existe a 'segunda interatividade', que diz respeito a programas que reagem de forma inusitada (tanto para o interator como para o próprio autor). A interatividade dos videogames é aquela que permite exploração e surpresa e, ao mesmo tempo, é coerente e razoavelmente previsivel. (...) Previsibilidade e interatividade não são conceitos opostos. Suponha que, em um ambiente virtual, exista um interruptor e uma parede. O avatar do jogador muda sua posição (...) Se a ação acontecer na própria sala e for aquela que se espera de um interruptor real, então o jogador sabe que interagiu, ainda que não tenha ficado muito surpreso. No entanto, se a ação do interruptor acontecer em outro aposento, como o jogador saberá que houve interatividade? Ele poderá, no futuro - e se o autor se preocupar em mostrar que uma tal sala, bem à frente na história, tem sua configuração alterada devido àquele interruptor -, descobrir que sua ação resultou em algo, mas a demora na resposta frustra o jogador. Assim, interatividade deve encontrar um equilibrio entre a surpresa e a

${ }^{42}$ ASSIS, Jesus de Paula. Artes do Videogame. 2007: p. 13. 
previsibilidade. (...) Ou seja, queremos intervir, saber como, saber por que e saber qual o resultado." ${ }^{43}$

A este desejo e efetiva intervenção, chamamos agência, isto é, a capacidade de agir de forma significativa e ver os resultados de nossas decisões e opções. Sabemos que em ambientes narrativos, nossa força de agência é bastante limitada em função da coerência textual, mas ainda assim é possível "agir" num bosque ficcional ao nos apropriarmos das regras da narrativa, abrindo espaço para que se considere o interator uma espécie limitada co-autor da narrativa, já que determinará caminhos a ser seguidos e poderá, inclusive, acrescentar novas trilhas e paisagens ao seu bosque particular. ${ }^{44}$

Murray afirma também que a agência vai além da participação e da atividade e amplia a discussão do real interesse em se criar narrativas interativas:

\begin{abstract}
"Como prazer estético, uma experiência a ser saboreada por si mesma, ela é oferecida de modo limitado nas formas de arte tradicionais, mas é mais comumente encontrada nas atividades estruturadas a que chamamos jogos. Portanto, quando se transfere a narrativa para o computador, ela é inserida num domínio já moldado pelas estruturas dos jogos. Somos capazes de imaginar uma narrativa literária envolvente que se baseie numa estrutura de jogos sem ser diminuída por ela? Ou estamos apenas falando de um modo dispendioso de reescrever Hamlet para a máquina de fliperama? ${ }^{\text {’35 }}$
\end{abstract}

Este questionamento evidencia os próprios limites deste estudo e aponta o terceiro e mais importante paralelo aqui proposto: a autoria procedimental.

\title{
Autoria Procedimental e Escrita Cúmplice
}

Enquanto apenas um artifício de desconstrução e reconstrução de formas teatrais, o modelo narrativo das mídias digitais pouco interessa. Na tentativa de criar textos que não

\footnotetext{
${ }^{43}$ ASSIS, 2007: 31-32

${ }^{44} \mathrm{~J}$. H. Murray estabelece o conceito de autoria procedimental, isto é, o autor é aquele que escreve as regras pelas para o envolvimento do interator.

${ }^{45}$ MURRAY, 2003: 129
} 
privilegiassem qualquer ordem de leitura ou modelo interpretativo, os pós-modernistas acabaram por privilegiar a própria confusão. A estrutura indeterminada desses hipertextos frustra nosso desejo de agência narrativa, ao usar o ato da navegação para desdobrar uma história que flui de nossas próprias escolhas significativas. ${ }^{46}$

Porém, o hipertexto pode, também, ser bastante promissor enquanto estrutura expressiva.

\begin{abstract}
"Uma história linear, não importa o quão complexa ela seja, caminha para uma versão única e acabada de um complexo evento humano. Até as histórias multiformes que oferecem várias releituras de um mesmo acontecimento frequentemente desembocam numa única $e$ 'verdadeira' versão - o ponto de vista da testemunha ocular não envolvida com o fato ou a autêntica realidade na qual os protagonistas terminas após as realidades alternativas terem desmoronado. Uma história linear deve terminar em algum lugar: a última imagem de um filme nunca é a de uma tela dividida. Mas uma história com múltiplas linhas narrativas pode oferecer muitas vozes ao mesmo tempo sem dar a nenhuma delas a palavra final. ${ }^{\text {A7 }}$
\end{abstract}

E é exatemente nesse sentido descrito acima que a agência/navegação por estruturas dramáticas interessou ao processo criativo de Escuro, como veremos no terceiro capítulo. 0 texto criado é, literalmente, um mapa de linhas narrativas simultâneas, ora congruentes ora paralelas. Esse mapa dramatúrgico é capaz de gerar tantos espetáculos quantos forem os diversos agenciamentos de narrativas realizados em seu processo de encenação.

Pode-se falar, então, em autoria procedimental ao procurarmos entender de que modo um mapa dramatúrgico é matriz de diversos textos potenciais. O conceito de autoria procedimental foi assim descrito por Janet Murray:

"Autoria procedimental significa escrever as regras pelas quais os textos aparecem tanto quanto escrever os próprios textos. Significa escrever as regras para o envolvimento do interator, isto é, as condições sob as quais as coisas acontecerão em resposta às ações dos participantes. Significa estabelecer as propriedades dos objetos e dos potenciais objetos no mundo virtual, bem como as fórmulas de como

\footnotetext{
${ }^{46}$ MURRAY, 2003: 133.

${ }^{47}$ MURRAY, 2003: 136.
} 
eles se relacionarão uns com os outros. O autor procedimental não cria simplesmente um conjunto de cenas, mas um mundo de possibilidades narrativas. $^{\prime 48}$

Assim, o mapa dramatúrgico de Escuro (apresentado no capítulo 3) fornece um quadro de possibilidades aos interatores (encenador, atores) em contato com a obra. O autor não cria mais um quadro narrativo com início e fim (em que apenas a interpretação subjetiva dos interatores modificará a obra), mas diversos quadros virtuais de enredo (cenas, narrativas) prontos a serem atualizados. Esses quadros poderiam, por exemplo, incluir um terminal "modal", contendo regras de substituição que permitiriam que os mesmos elementos genéricos fossem agrupados de formas bastante diferentes. Não se trata, porém, de uma autoria compartilhada. Isso porque

\begin{abstract}
"o interator não é o autor da narrativa, embora ele possa vivenciar um dos aspectos mais excitantes da criação artística - a emoção de exercer o poder sobre materiais sedutores e plásticos. Isso não é autoria, mas agência." ${ }^{\prime 49}$
\end{abstract}

Os papéis de autor procedimental e interatores são bastante distintos, já que o primeiro é o criador dos procedimentos ou linhas narrativas já formatados para serem organizados e reorganizados de diversas formas; o segundo, é aquele que realizará um dos possíveis agenciamentos pressupostos pelo autor. No caso de Escuro, como veremos, o mapa dramatúrgico acabou por resultar em um espetáculo que realizou temporada em São Pauloum agenciamento feito por diretor e atores em sala de ensaio.

Poeticamente, poderíamos falar de uma escrita cúmplice. Voltemos à metáfora do bosque de Umberto Eco para nos referirmos uma escrita nos transporta para uma nova geografia da ficção, em que mais do que palavras, somos levados à mergulhar em espaços imaginários, abertos e receptivos à nossa intervenção. Um bosque hipertextual é, então, um espaço imersivo e de agenciamentos - um jardim em que autores e interatores não se misturam, mas agem de forma conjunta, cúmplice; um espaço em que nossa memória individual e a memória coletiva se emaranham numa mesma virtualidade.

\footnotetext{
48 MURRAY, 2003: 150.

${ }^{49}$ MURRAY, 2003: 150.
} 
"Esse emaranhado de memória individual e memória coletiva prolonga nossa vida, fazendo-a recuar no tempo, e nos parece uma promessa de imortalidade. Quando partilhamos dessa memória coletiva (através das histórias de nossos antepassados ou através dos livros), somos como Borges contemplando o mágico Aleph - o ponto que contém o universo inteiro. (...) $E$, assim, é fácil entender por que a fição nos fascina tanto. Ela nos proporciona a oportunidade de utilizar infinitamente nossas faculdades para perceber o mundo e reconstituir o passado. A ficção tem a mesma função dos jogos. Brincando as crianças aprendem a viver, porque simulam situações que poderão se encontrar como adultos. E é por meio da fiç̧ão que nós, adultos, exercitamos nossa capacidade de estruturar nossa experiência passada e presente. ${ }^{\prime 50}$

\footnotetext{
${ }^{50}$ ECO, 1991: 137.
} 


\section{PARTE II - IMERSÃO E AGÊNCIA: HIPERTEXTUALIDADE EM DRAMATURGIAS}

\section{Alguns paralelos}

A partir da descrição de algumas das características fundamentais do ambiente digital, estabeleceram-se três paralelos entre as terminologias e conceitos dessa área à análise de dramaturgias. Concretiza-se, neste capítulo, o transporte entre as terminologias e descrições das mídias de comunicação em rede e a dramaturgia teatral. Tais conceitos servirão de alicerce à análise dos fragmentos neste capítulo e, ainda, foram a inspiração e direcionamento criativo no processo de escrita e ensaios de Escuro (descritos no terceiro capítulo)

É importante destacar que não se pretende determinar uma tendência ou unidade entre os fragmentos apontados. Ao contrário, a intenção é evidenciar a multiplicidade da dramaturgia contemporânea e promover um exercício de análise de fragmentos que nortearam uma criação artística.

Os fragmentos escolhidos aqui nem são tão recentes (posteriores à decada de 1980), mas se encaixam no que Jean-Pierre Ryngaert aponta como uma nova geração de escrita teatral:

\footnotetext{
"Agora, quase quinze anos depois, a diferença aumentou ainda mais entre os textos obedecendo a regras antigas (ainda que estes ainda sejam a maioria) e aqueles (..) que desafiam os princípios de drama absoluto como teorizado por Peter Szondi e definido por ele como "um evento interpessoal no presente." ${ }^{51}$
}

\footnotetext{
${ }^{51}$ RYNGAERT, Jean-Pierre. Speech in Tatters: The interplay of Voices in Recent Dramatic Writing. 2007: p. 14 Tradução livre a partir de "Now, almost fifteen years later, the gap has widened even more between texts obeying old rules (thoug these are still the majority) and those (...) that challenge de principles of absolute drama as theorized by Peter Szondi and defined by him as an interpersonal event in the present."
} 
É possível, sem apontar nenhuma tendência em particular, listar algumas características comuns a esta geração descrita por Jean-Pierre Ryngaert. Segundo ele, qualquer lista que descrevesse a dramaturgia desse período deveria incluir

“...o desmantelamento de linha da história e ação, a organização fragmentada, uma despedida (ou pelo menos um au revoir) aos personagens, o rompimento do diálogo, a morte da ilusão, fim da 'dupla enunciação' como uma forma lógica de transmissão de informações para o leitor / espectador. A esses recursos podem ser adicionadas tendências, como forma de compensação, tais como a 'novelização' do teatro (a subversão da forma dramática pela novela.), é 'poeticização' (um retorno importante para o lirismo) e confiança na abordagem direta a audiência." ${ }^{52}$

Assim, o transporte de terminologias de análise deste trabalho se justifica como uma tentativa de abordar uma dramaturgia que, ao se reorganizar, se multiplicar e se reinventar por vezes de forma confusa e excessiva, segundo Ryngaert - propõe uma transformação na escrita teatral e um outro ângulo de abordagem da ficção e do drama. Os três conceitos transportados são hipertextualidade, imersão, agência (o que naturalmente nos leva ao conceito de autoria procedimental, como já visto. $)^{53}$

A hipertextualidade pressuporia, então, uma dramaturgia espacial - rizomática, fragmentada, multilinearizada, multissequencial e indeterminada. Agência refere-se às lacunas e a intervenção direta do leitor/navegador na forma de leitura e construção de sentidos. Os exemplos utilizado nesse caso são fragmentos da dramaturgia do francês Michel Vinaver. Depois, fala-se de autoria procedimental para uma breve análise da estrutura proposta por Simon McBurney, do Theatre de Complicité, na publicação da peça "The Streets of Crocodile", de 1992. Já o conceito de imersão serve para uma análise do constante confronto entre realidade e ficção proposto pelo argentino Federico Léon (principalmente utilizando um sua

\footnotetext{
52 Tradução livre a partir de:" the dismantling of story-line and action, fragmented organization, a fareweel (or at least an au revoir) to characters, the breaking up of dialogue, the death of illusion, and the end of 'double enunciation' as a logical way of conveying information to the reader/spectator. To these features might be added such countervailing tendencies as the 'novelization' of the theater (the subversion of the dramatic form by the novel form); it's 'poetrification' (a major return to lyricism); and reliance on the direct addressing of the audience." (RYNGAERT, 2007: 16)

${ }^{53}$ Estas terminologias são utilizadas por diversos teóricos de narrativas eletrônicas, mas aqui, referem-se principalmente às descrições de Janet $\mathrm{H}$. Murray.
} 
aclamada peça “Museo Miguel Ángel Bozzeo"). É definido, por fim, do conceito de narrativas caleidoscópicas que norteou a criação de "Escuro".

\section{Dramaturgias de Paisagem}

O filósofo francês Gaston Bachelard escreve que todo espaço pode ser experimentado tanto em suas dimensões imaginárias como físicas: um sótão, por exemplo, poderia ser experimentado tanto como uma espaço de refúgio como um lugar de devaneio, de fuga para outra dimensão. ${ }^{54}$ Pensar em uma dramaturgia espacial corresponderia a incluir na esfera poética também a fisiologia (ou topologia) do texto. O primeiro paralelo aqui proposto procura aproximar um tipo de escrita dramatúrgica que substitui um percurso linear por um trajeto espacial, construído por

"linhas de articulação ou segmentaridade, estratos, territorialidades, mas também linhas de fuga, movimentos de desterritorialização $e$ desestratificação" ${ }^{55}$.

Com topologias e formas de navegação similares aos hipertextos ${ }^{56}$, os fragmentos que serão citados neste capítulo (e que se unem aqui por terem servido como inspiração à criação dramatúrgica) questionam os componentes fundamentais ao drama: a forma dialógica interpossal, sujeitos em confronto; a fala estruturada para criar tensões, oposições e decisões; a ação no presente. ${ }^{57}$

Michel Vinaver, o autor dos fragmentos apresentados, estabelece uma clara distinção entre "les pièces-machines" - aquelas peças modeladas a partir desses componentes fundamentais, desenhadas com a regras de uma dramaturgia clássica - e as suas "pièces-

\footnotetext{
${ }^{54}$ BACHELARD, Gaston. Os Pensadores. São Paulo: Abril Cultural, 1976.

${ }^{55}$ DELEUZE, GUATTARI. Mil Platôs. Vol 1. - p. 10

5656 Segundo Carlos Irineu da Costa : "Hipertexto - Uma forma não linear de apresentar e consultar informações. Um hipertexto vincula as informações contidas em seus documentos (ou 'hiperdocumentos', como preferem alguns) criando uma rede de associações complexas através de hiperlinks, ou mais simplesmente, links."

${ }^{57}$ LEHMANN, op. cit.
} 
paysages", 58 explicando que uma paisagem pode ser mapeada em uma série de diferentes caminhos, um algoritmo variável - talvez infinito - de percursos. Esta poderia, evidentemente, também ser uma das definições para um hipertexto, como já vimos anteriormente.

Essa ideia de uma "peça paisagem", porém, é anterior à Michel Vinaver, já tendo sido apresentada por Gertrude Stein. O autor francês, entretanto, define esse conceito de um modo inédito e, em um certo sentido, oposto ao conceito suscitado anteriormente pelos textos da escritora americana.

Os textos de Stein (1874-1946) são cheios de repetições intencionais de vocábulos, muitos monossílabos; as palavras não são geradoras de um sentido claro, aproximando-se muito mais de experimentos sonoros. Lehmann afirma que a dramaturgia de Stein - que concebe o palco e o texto como uma paisagem- faz parte da pré-história de seu teatro pós-dramático, aparecendo em um momento paralelo à crise do drama (e "as tentativas de solução" e "tentativas de salvação" descritas por Peter Szondi), em que começa a surgir um cetismo quanto à compatibilidade entre drama e teatro; o teatro passa a ser reconhecido como algo com premissas autônomas, distintas e até contrárias às premissas da literatura dramática.

Lehmann descreve a dramaturgia da americana como um texto que só contém narração e referências à realidade de um modo distorcido, uma tentativa de desvincular o teatro de outro tempo (o passado ou o futuro), substituindo um constante esforço de apreensão pela contemplação de uma paisagem. Assim Lehmann descreve a " peça-paisagem":

\footnotetext{
"Nos textos de Stein, os esclarecimentos - bastante sucintos - de sua concepção teatral estão sempre ligados a imagens de paisagens verdadeiras. (...) Se com frequência existe a tentação de descrever o palco do novo teatro como paisagem, a responsabilidade é mais dos traços antecipados por Stein, de uma desfocalização e de uma equivalência das partes, da renúncia a uma época orientada teleologicamente e da predominância de uma 'atmosfera' sobre os procedimentos dramáticos e narrativos. (...) O texto de Stein já é de certo modo a paisagem. Em um grau até então inaudito, emancipa a oração em relação à frase, a palavra em relação à oração, o potencial fonético em relação ao potencial semântico, o som em relação ao
}

\footnotetext{
${ }^{58}$ VINAVEr, Théatre Complet 4 (Paris: L'Arche, 2002): 92
} 
sentido. Assim como em seus textos a reprodução da realidade dá lugar ao jogo das palavras, no 'teatro Stein' não se encontra drama algum, nem mesmo uma história, não se podem distinguir quaisquer protagonistas e faltam até papéis e personagens identificáveis" ${ }^{\prime 59}$

Vale ainda destacar que Lehmann ainda cita Thorton Wilder em "The Death of the Character":

"Um mito não é uma história lida da esquerda para a direita, do começo ao fim, mas uma coisa que se tem inteiramente à vista o tempo todo. Talvez seja isso o que quis dizer Gertrude Stein quando afirmou que daqui em diante a peça é uma paisagem.

Esta citação nos remete diretamente ao que já foi dito sobre a forma de leitura de um hipertexto. Poderíamos dizer, através de um transporte metafórico entre campos de conhecimento distintos que tanto um hipertexto como uma peça-paisagem comportam, de modos e níveis diversos, as quatro características fundamentais do amibente digital (como descritas por Janet H. Murray): são espaciais, enciclopédicos, procedimentais e participativos.

As peças-paisagem de Gertrude Stein ligam-se, então, de forma direta ao processo de separação (ou autonomização) entre texto e cena e serviram a uma estética que privilegia a escrita cênica (a visualidade) ao texto teatral. Já com as "pièces-paysages" de Michel Vinaver, embora enfrentem um mesmo contexto de elevação do papel da encenação na hierarquia cênica ${ }^{61}$, veremos que a história é um pouco diferente.

\footnotetext{
${ }^{59}$ LEHMANN, 2007: 103-104

${ }^{60}$ (LEHMANN, 2007: 103) Tradução livre a partir de:" A myth is not a story read from the left to right, from beggining to end, but a thing held full-in-view the whole time. Perhaps this is what Gertrude Stein meant by saying that the play henceforth is a landscape."

${ }^{61}$ BRADBY, David. Michel Vinaver and La renverse: Between Writing and Stage.
} 


\section{Dramaturgia Hipertextual: O Pedido de Emprego, de Michel Vinaver}

Michel Vinaver (1927-) não reconhece seu processo de criação em nenhum movimento contemporâneo - como o brechtianismo, o teatro do quotidiano, o teatro histórico, ou texto como material-de-cena etc ${ }^{-62}$, mas sua obra teatral, a partir de 1956 , é de inegável importância e relevância no atual panorama de dramaturgias híbridas e múltiplas. Sua primeira peça é de 1939 (com apenas nove anos) e aos dezessete, escreve sua primeira novela. Romancista e tradutor de obras de T.S. Elliot, escreve sua primeira peça em 1955 ("Les Coréens"). Destacamse, de sua obra dramatúrgica, "Demand d'emploi", de 1972, "Dissident, il va san dire", de 1978, "L'Objecteur", de 2001, entre outras.

Escolher fragmentos deste autor francês para exemplificar a metáfora de uma dramaturgia hipertextual, como proposto aqui, é reconhecer o caráter fragmentário de seu texto - que mescla espaços imaginários e reais, paisagens diferentes justapostas através de diálogos sem dupla enunciação, permitindo uma navegação do leitor/espectador por uma rede emaranhada de conflitos dispersos,

\footnotetext{
"uma escrita poética calcada num inteligente processo de composição que reelabora o real pela linguagem e na linguagem, ou, 'à flor da linguagem" ('au ras du langage', termo seu). ${ }^{63}$
}

Sua carreira como dramaturgo concide com o período em que os diretores se estabeleceram como a voz mais forte do teatro francês. A ascensão do diretor na hierarquia teatral do século XX é um fenômeno complexo e aqui não é lugar para tentar um resumo. Mas, ao pretendermos contextualizar a obra de Vinaver, é preciso apontar alguns atributos do que David Bradby chama de "teatro de diretores". ${ }^{64}$

Bradby destaca dois pilares deste "teatro de diretores". O primeiro é que ele depende do desenvolvimento de um idioma próprio para que palco e plateia se comuniquem. Este idioma é composto de uma vasta gama de práticas significantes predominante visuais em vez

\footnotetext{
${ }^{62}$ SANTANNA, Catarina. Vinaver à flor da linguagem: entre heranças vanguardistas e brechtianas.

${ }^{63}$ SANTANNA, idem.

${ }^{64}$ Em um dos artigos da Yale French Studies. The Transparency of the Text. BRADBY, David. Op. cit. p. 71.
} 
de verbais. A partir dos experimentos de Meyerhold, passando por Artaud e Grotowski, e chegando a Bob Wilson, desenvolve-se uma abordagem para a encenação que não parte das palavras de um dramaturgo, mas das possibilidades expressivas desse "idioma cênico" - ele mesmo, em processo de formação. O segundo pilar deste "teatro de diretores" é que, quando não se opta por dispensar o texto de um dramaturgo, propõe-se uma nova interpretação aos textos. Assim, segundo Bradby, a maioria dos diretores que estão no comando dos teatros franceses atualmente estabeleceu-se através de novas produções de obras clássicas, cuja distinção reside na invenção e reinterpretação de textos conhecidos.

Vinaver opõe-se explicitamente a este movimento e gradualmente passa a formular suas próprias teorias sobre as dificuldades de se encenar sua redação teatral, sugerindo o melhor método de trabalho em suas peças. No entanto, só em 2006 é que ele transfere essa teoria para a prática, assumindo a direção profissional de um espetáculo de sua autoria. Desse modo, Vinaver escolhe o lado do escritor, nesta batalha entre texto e cena.

Restaurando a importância do texto teatral, Vinaver cria dramaturgias que privilegiam a multiplicidade de pontos de vista em vez de fornecer um único (do autor ou de um eventual encenador). Os pontos de vista são expressos, para Vinaver, por meio de uma voz que não é sua, mas de suas personagens ${ }^{65}$.

Numa lógica similar à encontrada em hipertextos, os textos de Vinaver são, então, construídos de forma horizontal, numa composição feita por justaposições de pontos-de-vista ou espaços, em que o mais importante não é o material (ou tema, ou diálogo) em si, mas a fricção entre as matérias justapostas. Vinaver compara seu processo criativo a métodos de composição musical e a estas fricções e conexões entre materiais diversos, ele nomeou "les mises en relation".

"Elas (les mises en relation) são o material puro - ou seja, elas ocorrem no nível material do objeto linguístico - efeitos rítmicos, colisões de sons, mudanças de sentido de uma frase para outra, colisão

\footnotetext{
${ }^{65}$ VINAVER, Michel, Écrits sur le théâthre 2. Paris: L’Arche, 1998: 93
} 
desencadeando o que poderíamos chamar de mini-fenônemos de ironia explosiva". 66

O seguinte fragmento de sua peça "Demand d'emploi", de 1972, ilustra claramente a proposição de Vinaver:

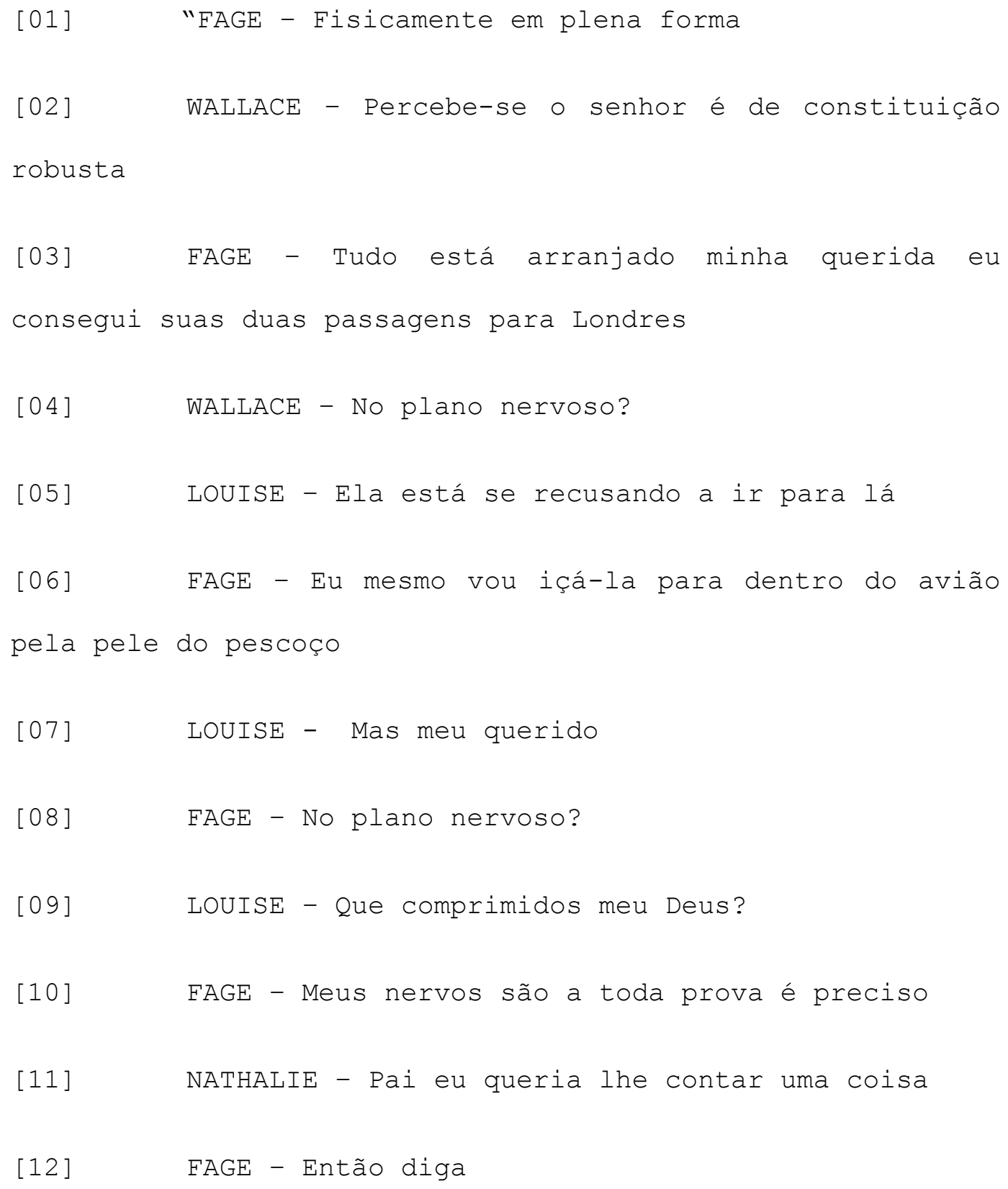

\footnotetext{
${ }^{66}$ Michel Vinaver, citado por David Bradby. Tradução livre a partir de: "They (les mises en relation) are the material in nature - that is to say that they take place at the level of the linguistic material - rhytimic effects, collisions of sounds, shifts of meaning from one sentence to another, collision setting off what one might call mini-phenomena of explosive irony."
} 


$$
\text { LOUISE - São frequentemente as pequenas coisas }
$$

que contam querido em um primeiro contato são elas que podem ser determinantes se tivermos tomado o cuidado de engraxar os sapatos se as unhas estiverem limpas FAGE - Eu sei se o nó da gravata estiver bem no meio do colarinho NATHALIE - Você viu ele pai eu trouxe ele aqui em casa duas ou três vezes

$$
\text { LOUISE - Se a camisa }
$$$$
\text { WALLACE - Conte }
$$

estamos procurando é o controle do acontecimento do qual ele é capaz ou melhor o controle do qual ele é capaz

$$
\text { FAGE - Não se deixar desviar }
$$


Percebemos, neste fragmento, um evidente desencaixe dos diálogos - um efeito similar a uma montagem de falas, caracterizado pela desordem do diálogo (respostas atrasadas) e sobreposição de conversas, tendo como eixo de rotação e fricção a personagem FAGE.

Distinguem-se, pelo menos, três situações dialógicas diferentes no fragmento: o primeiro entre WALLACE e FAGE (acerca de uma entrevista de emprego); outro entre FAGE e LOUISE (sobre uma possível viagem a Londres de sua filha - para um aborto, como se saberá no decorrer da peça - e sobre a melhor maneira de se comportar em uma entrevista de emprego); e finalmente, entre FAGE/NATHALIE (em que a filha conta ao pai que está grávida). Entre estas situações bastante distintas, encontramos ainda falas que servem a mais de uma situação, isto é, funcionam como intersecção, como eixos sobre os quais as situações giram. Por exemplo, as fala [8], [20] e [25] claramente provocam um curto-circuito ora linguístico ora de sentido entre as situações justapostas.

Podemos, novamente, citar David Bradby, em seu artigo "Michel Vinaver and A la renverse: between writing and staging":

\begin{abstract}
"Vinaver gosta de comparar seus métodos de composição com os pintores e músicos. Antecendo sua peça Iphigénie Hotel, ele cita Georges Braque, em um trecho em que Braque enfatiza que o que ele pinta não são somente os objetos representados na tela mas também o espaço entre eles, e Vinaver salienta a importância do 'entre' em sua escrita. A citação (...) continua com estas palavras: 'e estes pontos de vista não são tão interessantes em si mesmos, pelo que são, mas sim pelo atrito que ocorre entre eles.' Da forma musical, ele adotou o método de sobreposição de vozes diferentes e simultâneas. No palco, não é possivel ter várias pessoas falando ao mesmo tempo, ou tudo o público ouve é ruído, mas Vinaver sugere um efeito semelhante ao de, digamos, um quarteto de cordas - em que quatro instrumentos distintos tocam linhas melódicas separadas - justapondo e misturando duas ou mais conversas, de modo que diferentes discursos se
\end{abstract}

\footnotetext{
${ }^{67}$ Tradução de Paulo Roberto Massaro para o o Seminário de Pós-Graduação Novas Formas de Diálogo Teatral, ministrado pleo Prof. Dr. Jean-Pierre Ryngaert de 10 a 25 de novembro de 2008 no Departamento de Artes Cênicas da Escola de Comunicação e Artes de São Paulo.
} 
sobreponham e que o leitor de suas peças freqüentemente esteja

incerto quanto a quem é dirigida determinada fala." 68

O resultado deste método de composição é uma série de situações paralelas, fragmentadas estruturas dramáticas que sobrepõem diferentes vozes, situações, histórias, apresentando um mundo ficcional inesperado que, por ser simultâneo, abre fissuras e pontos de contato (les mise en relacion) que alteram nossa percepção. Como o resultado desta composição, torna-se impossível identificar um enredo linear que conduz ao clímax reconhecível na forma clássica, ou mesmo fazer a distinção entre uma trama principal e outras subtramas. Em vez disso, encontra-se um entrelaçamento de acontecimentos, personagens e situações - uma paisagem que só poderá ser construída por agenciamentos da imaginação do espectador. Esta paisagem

"[...pode ser um lugar em que se pode perder assim um lugar no qual se pode descobrir a si mesmo, mas não se pode dizer que há uma maneira de entrar nele melhor que outra. Michel Corvin recentemente resumiu a originalidade do método de Vinaver, dizendo que ele provoca curto-circuito entre conceitos de foco e de cronologia sequencial, ou ainda entre espacialidades diferentes, em que um todo que só pode ser apreendido pela imaginação do leitor. ${ }^{69}$

\footnotetext{
${ }^{68}$ BRADBY, David. Yale French Studies. Pp. 73-74.

Tradução livre a partir de: "Vinaver enjoys comparing his compositional methods to those of painters and musicians. At the head of his play Iphigénie Hotel, he set a quotation by Georges Braque, in which Braque emphasized that what he painted was not so much the objects depicted on the canvas as the space in between, and Vinaver stresses the importance of the 'in between' for his writing. The earlier citation regarding points of view continues with these words: 'and these point of views are not so much interesting in themselves, for what they are, but through the friction that occurs among them.' From musical form, he adopted the method of superimposing different voices simultaneously. On stage it is not possible to have several people talking over one another, or all the audience hears is a babble; but Vinaver aims for a similar effect to that of, say, the string quartet, in which four instruments play separate melodic lines, by juxtaposing and intermingling two or more conversations, so that different discourses overlap and the reader of his plays is frequently uncertain as to whom a given remark is addressed."

69 Tradução livre a partir de: “(...) can be a place in which to be lost as well a place in which one can discover oneself, but no one way of entering it can be said to be better than any other. Michel Corvin recently summed up the originality of Vinaver's method by saying that he short-circuits at one and the same time concepts of focus of sequential chronology, or differential spatiality, in favor of a whole that can only be grasped by the reader's imagination." (BRADY, 2007: 74)
} 


\section{Agenciamento em dramaturgia: $O$ dissidente, de Michel Vinaver}

É interessante, ainda, analisar brevemente um outro fragmento do autor - um trecho de "Dissident, il va san dire"70, de 1978, desta vez observando a estrutura dos diálogos propostas.

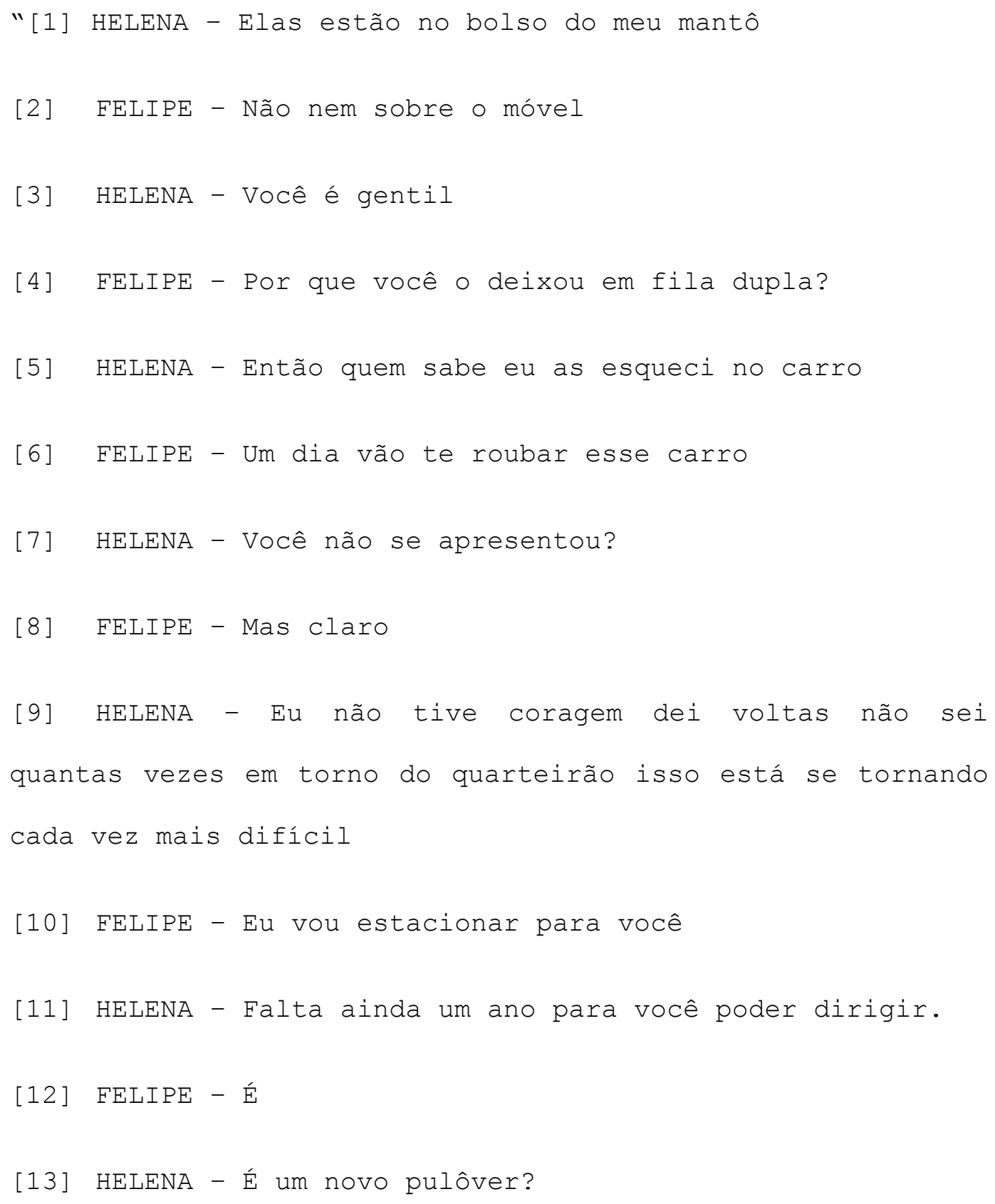

${ }^{70}$ Traduzida no Brasil como “O Dissidente”, por Catarina Sant'Anna. Editora da Universidade de São Paulo, 2007. 


\section{[14] FELIPE - É \\ [15] HELENA - Eu me pergunto de onde vem o dinheiro."71}

Este pequeno trecho de nos revela, imediatamente, características muito particulares a todo o texto, que subvertem as idéias comuns associadas à composição de um "drama": os diálogos sem pontuação salvo os pontos de interrogação ${ }^{72}$, a ausência de didascálias evidentes, as falas desencontradas ou sem respostas, a mistura súbita de referentes e de tonalidades emocionais as mais diversas no interior de uma mesma fala de personagem, um laconismo geral denso de informação e grande presença de situações implícitas.

Vinaver compõe uma dramaturgia que ultrapassa a categoria de "diálogo" (entendido como fala com propósito, recheada de duplas enunciações que anteveem a presença do público) e alcança o estatuto de "pedaço de real". É como se invadíssemos a vida de dois seres reunidos em um universo autônomo e fôssemos obrigados a "supor" do que se trata aquele momento - somos encorajados a criar nós mesmos os elos, a costurar os pedaços.

Seria, no entanto, injusto, reduzir a composição detalhada de Vinaver, a um extremo naturalismo cotidiano e não considerar a paisagem meticulosamente recortada por ele. Destacam-se, nesse excerto, alguns dos fundamentos da "dramaturgia de paisagem" de Michel Vinaver. Vejamos:

a. a importância das lacunas para sua escrita: no fragmento de diálogo entre Helena e Felipe, Vinaver abre mão da dupla enunciação ${ }^{73}$ e privilegia as relações implícitas entre as personagens. Somos obrigados a construir mentalmente imagens e ações que ocupam os espaços entre as falas. Podemos identificar uma ação "atrás das falas": a procura da chave. Além disso, é nas incontáveis relações implícitas entre eles ([6] e [7], por exemplo) que percebemos a situação em que estão envolvidos, o perfil de cada um dos protagonistas (podemos imaginar a idade de Felipe na linha [11]) e a relação de desconfiança e segredos

\footnotetext{
${ }^{71}$ Fragmento da cena UM, de O Dissidente, de Michel Vinaver. Tradução de Catarina Sant'Anna.

${ }^{72}$ A tradução de Catarina Sant'Anna acrescenta pontos de interrogação em falas textualmente interrogativas, que no francês se beneficiam da estrutura da língua.

${ }^{73}$ Para maior detalhamento deste termo, ver Ubersfeld, Anne. Para ler Teatro.
} 
entre mãe e filho (o conflito estabelece-se na linha [15]). Todo o conflito e toda ação acontecem nos espaços "entre" as falas.

Desse modo,

\begin{abstract}
"ler Vinaver consiste em tatear o texto, como que criá-lo no momento justo da leitura, o que proporciona um prazer estético suplementar, uma fruição já evidente de "receptor-criador" que interage, ousa, avança, pára, refaz e, desse modo, visualiza a cena, veste o personagem, age com ele, compreende-o, passa a ouvi-lo, tal como sucede nas falas entrecortas, sincopadas da vida cotidiana.O mistério não se desfaz, todavia. Restam as pausas e os silêncios a demondar o tom adequado, bem como o ritmo certo para as trocas de fala $e$ interrupções. É o fenômeno da oralização teatral que brota no leitor $e$ faz dele um ator, um encenador do que lê. Somos impulsionados a ler em voz alta, a experimentar as falas, a descobrir no final a simplicidade de tudo, enfim. ${ }^{, 74}$
\end{abstract}

Nesse processo de decodificação, a linguagem ganha volume, espessura, apresenta arestas, parece constituir-se por vezes, de blocos removíveis, não somente no plano linear mas também tridimensionalmente. Somos levados a supor objetos, direções e ações que ocupem as lacunas, o que não está expressamente indicado, mas que são realizadas pelas personagens enquanto falam. É, como afirma Sant'Anna, o "reino das didascálias internas", sub-reptícias.

b. a sobreposição de vozes e a extrema oralidade: a linguagem de Vinaver ganha relevos de conversa, de fala corpórea. No fragmento em questão, por exemplo, encontramos uma escrita que dança pelo acaso dos diálogos. Diferentemente de Theckov, o acaso e a banalidade não são apenas aparentes, mas a própria essência do diálogo: não há que se procurar nada de profundo na superfície. A frase de Paul Valèry - "o mais profundo é a pele." aplica-se perfeitamente a escrita de Vinaver. Os temas cotidianos e ordinários ocupam toda o diálogo, o que se torna evidente nas rupturas (respostas ausentes ou atrasadas), na sobreposição de falas e na transcrição da linguagem oral.

c. a multiplicidade e simultaneidade de situações e a ausência de uma trama: nesse jogo superfícies, o texto escorre, sem eixo dramático, à procura de uma história. Cada

\footnotetext{
${ }^{74}$ SANT'ANNA. Op. cit. P. 14
} 
detalhe cotidiano ganha relevo na sucessão de cenas, impedindo a instalação hegemônica de um ponto de vista, negando o nítido desenho de uma estrutura dramática. No fragmento, por exemplo, o conflito entre mãe e filho, e possível envolvimento dele com drogas, aparece na linha [15] ocupa o mesmo plano que a perda das chaves (linhas [1] a [5]) ou os problemas de Helena ao estacionar o carro ([9] e [10]).

Assim, o autor constrói uma situação, uma paisagem, a partir da linguagem falada, evitando escolher tema ou assunto, questão ou eixo para sua dramaturgia; preferindo vagar entre as lacunas de conversas a criar situações dramáticas mascaradas de relações interpessoais.

Esse tipo de dramaturgia, então, coloca a conversa como eixo da ação. (Não interessam mais os diálogos bem construídos e "essenciais" à trama.) A ação é mínima ou totalmente implícita, quase não somos capazes de reconhecer uma fábula. Mesmo as personagens, quando aparecem, são enigmáticas ou incompletas. Nestas condições, só resta ao drama a "palavra". Perdida, fragmentada e sem interlocutores, incapaz de ser claramente endereçada ou catalogada, não mais ligada à narrativa, mas a uma paisagem, a palavra torna-se ação.

A palavra passa a ser o alicerce para a criação de uma dramaturgia múltipla, instigante, cheia de lacunas e que exige a participação intensa e ativa do leitor/espectador. E neste ponto justifica-se o transporte do termo "agência" para tratar deste tipo de dramaturgia.

\section{Autoria Procedimental: The Street of Crocodiles, Theatre de Complicitè}

É claro que outras formas mais explícitas de agência -e não exclusivamente pertencentes à imaginação do ator/espectador ao preencher as lacunas deste bosque incompleto - podem ser encontradas em outros textos teatrais da cena atual. Poderíamos, por exemplo, citar a forma (ainda para não fugirmos da tipologia do texto) escolhida para a publicação (em 1997) do texto do espetáculo The Street of Crocodiles, uma criação do Theatre 
de Complicitè, escrita por Simon McBurney e Mark Wheatley, que estreou no Royal National Theatre Studio, em Londres, em 1992.

Depois de se graduar na Cambridge University, Simon McBurney treinou na Escola de Jacques Lecoq em Paris antes de retornar a Londres em 1983 e co-fundar da companhia inglesa Theatre de Complicitè. Tendo criado quase trinta espetáculos ao longo desses anos, o Complicitè se estabeleceu como uma das companhias mais populares, influentes e aclamadas pela crítica mundial, trafegando com sucesso entre a ilusória divisão entre experimentos de vanguarda e gosto popular. ${ }^{75}$

Um dos atributos mais marcantes de McBurney é sua facilidade em crar imagens que desterritorializam e reinscrevem a cartografia do convencial. Neste novo mapa, a imagem não é simplesmente representação pictórica ou efeito teatral, mas um agenciamento de lógicas poéticas e de formas e narrativas em jogo com o espetáculo. Elas surgem da distribuição, interação e transposição de corpos e objetos em cena, cristalizados em metáforas efêmeras antes que se dispersem e retornem ao palco como potência. Mnemonic ${ }^{76}$ (1999), por exemplo, é povoada pelas ambigüidades das novas tecnologias de comunicação (o celular) e gravação (video). Uma linha telefônica surge em momentos de intensa "proximidade" entre as personagens, dolorosamente reinstalando a distância e a ausência, e a memória é voltada e adiantada repetidamente, como se fosse uma gravação, numa busca obssessiva por origens. Ao mesmo tempo, o ritmo descontínuo de um controle remoto ou da ilha de edição determinam a

\footnotetext{
${ }^{75}$ Apresentam-se a seguir, sinteticamente, alguns nós de intersecção que fazem do conceito de hipertexto dramático e da poética do Theatre de Complicitè partes constituintes de uma mesma tessitura em rede e, logo, justifica-se sua inserção como um dos exemplos desta dissertação. Estes nós evidenciam-se no legado deixado por Jacques Lecoq no trabalho de McBurney: o teatro visto como um organismo múltiplo e descentralizado (o "universal sem totalidade" proposto por Pierre Lèvy ao descrever ao labirinto da internet, desenhado e redesenhado várias vezes - móvel, em expansão, sem plano possível, constituindo uma universalidade desprovida de significado central); o ator encarado como um contador de histórias multifacetado e móvel (o ator como corpo virtual - um corpo de potências múltiplas, pronto a atualizar-se por outramentos); a criação de sugestões, de formas incompletas para criar uma cumplicidade imaginativa com os espectadores, ativando sua capacidade, cada atualização nos revelando um novo aspecto - ainda mais, alguns dispositivos não se contentam em declinar uma combinatória, mas suscitam, ao longo das interações, a emergência de formas absolutamente imprevisíveis. Assim, o evento de criação não se encontra mais limitado ao momento da concepção ou da realização da obra. Nesse sentido, a imaginação do leitor surge também como um dispositivo de memória coletiva.(segundo Levy, característica fundamental do ambiente digital).

${ }^{76}$ McBURNEY, Simon. Complicite - Plays One. Metheun, 1999.
} 
própria encenação: sequências inteiras são "rebobinadas" em velocidade vertiginosa e retocadas inúmeras vezes, jogando com a virtualidade e a atualidade.

Em suma, as temporalidades elásticas, o deslocamento e a mobilidade de sentidos, a conectividade e fluidez da memória e identidade são temas recorrentes ao trabalho de McBurney. Em todas as suas produções, os componentes estruturais do texto e da cena são encorajados a mudarem e se recomporem, a se deslocarem, se multiplicarem e se reinventarem temporariamente, adotando configurações efêmeras e identidades próprias de uma linguagem teatral que está, por si mesma, migrando, transformando e sempre em movimento.

O universo da peça The Street of Crocodiles é exatamente o mesmo da imaginação, da inconsciência e da memória. Contos do escritor polonês Bruno Schulz, morto em 1997, foram a inspiração da peça e seus fragmentos descrevem, através dos olhos de uma criança, uma pequena cidade na Galícia no final do Império Austro-húngaro - a perda da infância como metáfora para o fim de um império e o choque de um novo século, segundo o próprio autor ${ }^{77}$. A peça é toda construída em fragmentos, imagens aparantemente aleatórias que desconstroem e reconstroem em fábula a vida da Schulz. Para a publicação desta peça, pela Editora Metheun, os autores alertam sobre a impossibilidade de transformar em literatura dramática a potência visual do espetáculo e preferem publicar o texto não como a transcrição das falas e imagens construídas em cena, mas como uma mapa que guiasse o leitor e o levasse, de forma cúmplice, reescrever o espetáculo. Em suas palavras, em nota que introduz o texto publicado:

\begin{abstract}
"Assim, este livro não é mais o registro de um processo do que um texto para se representar, um mapa, em vez de uma peça. Uma peça é um lugar que exige ser habitado, ambos origem e destino, ligados por um caminho claramente definido. O mapa indica a paisagem, sugere uma multiplicidade de sentidos, mas não dita qual caminhoo você deve tomar. Um mapa, ainda que belo, é um guia, não um lugar. Se desejar visitar o lugar, leia os livros Schulz. E viaje". ${ }^{78}$
\end{abstract}

\footnotetext{
${ }^{77}$ McBURNEY, Simon. Idem.

${ }^{78}$ Intodução de McBurney para The Street of Crocodiles. Tradução livre a partir de: "So, this book is more the record of a process than a text for performance; a map rather than a play. A play is place which demands to be
} 
McBurney ainda afirma que, como os fragmentos encenados derivam de estruturas narrativas, cada início de cena é marcado por uma citação que direciona o leitor a observar a cena a partir do fragmento textual que inspirou uma certa escritura cênica. Por exemplo, a sétima cena do segundo ato, denominada "August", começa com a seguinte citação :

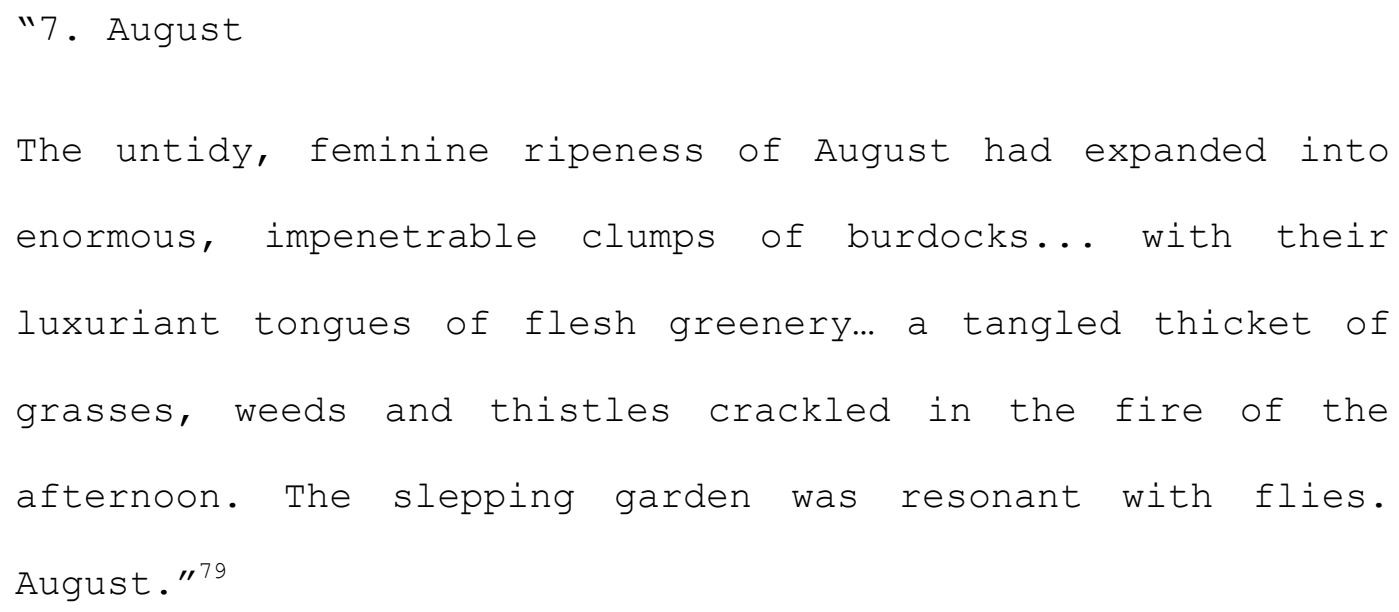

Na sequência, apresenta-se a transcrição de uma possível escrita cênica derivada dela:

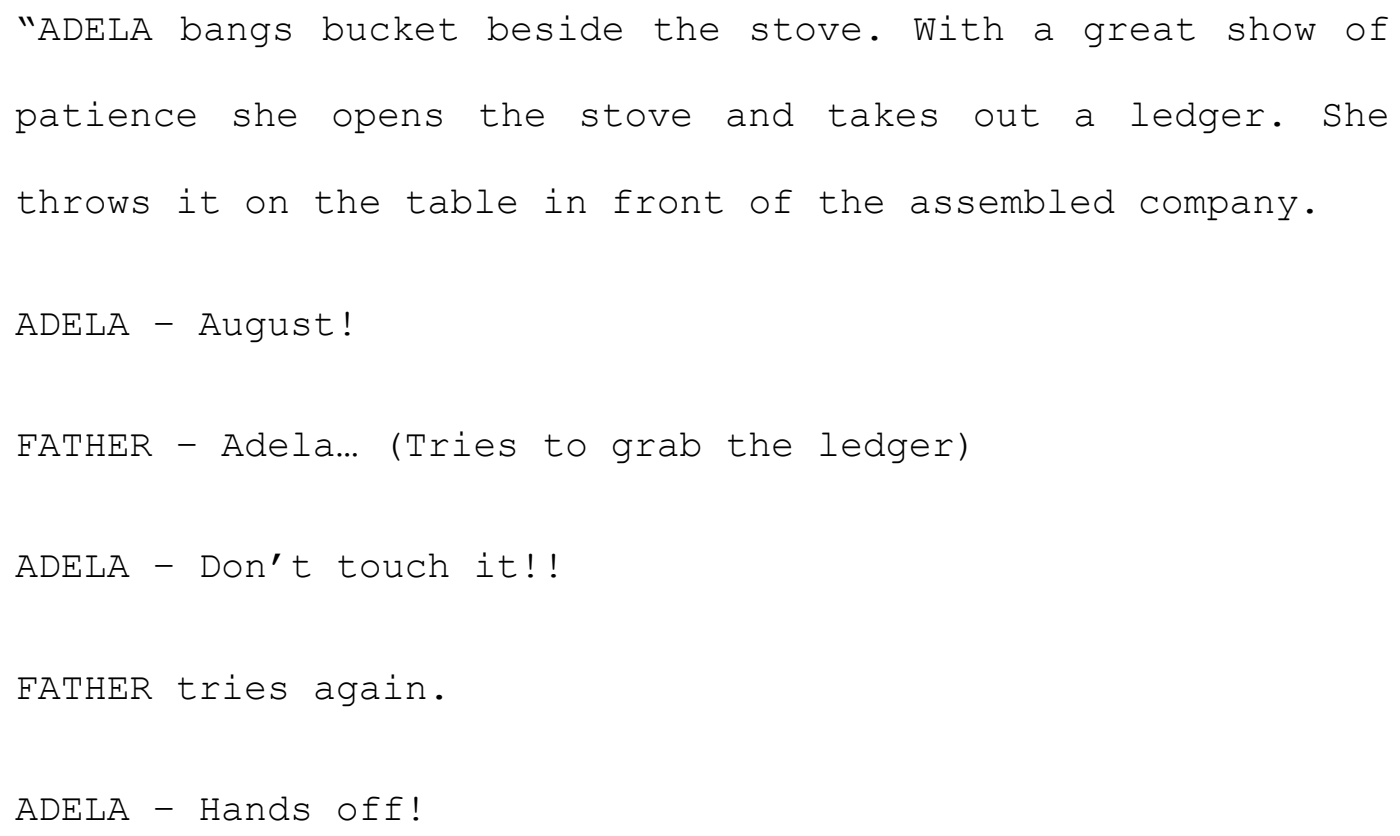

\footnotetext{
inhabited; both origin and destination, linked by a clearly determined path. A map indicates the landscape, suggests a multitude of directions, but does not dictate which one you should take. A map, however beautiful, is a guide not a site. If you wish to visit the site yourself, pick up Schulz's books. And travel." ${ }_{79}$ Optei, neste caso, por não traduzir a citação e a forma dramática propostas no corpo do texto, para preservar o formato proposto por McBurney.
} 


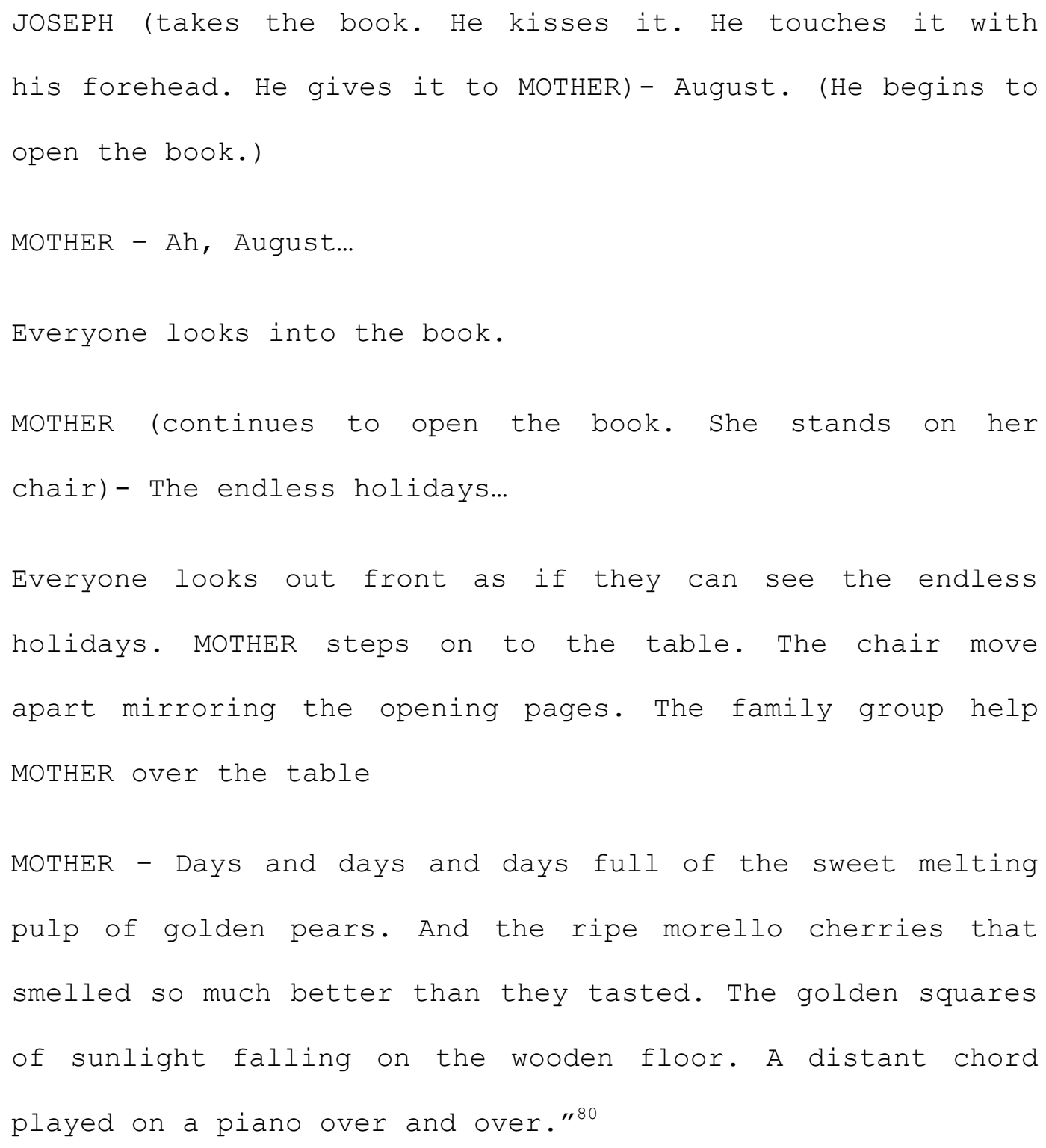

80 "ADELA acerta o balde ao lado do fogão. Com grande demonstração de paciência, ela abre o forno e tira um livro. Ela o joga na mesa em frente ao elenco

Adela - Agosto!

PAl - Adela ... (tenta agarrar o livro)

Adela - Não toque nele!

Pai tenta novamente.

Adela - Tira a mão!

JOSEPH (pega o livro. Ele o beija. Ele o toca com a testa. Ele o dá para a mãe) - Agosto. (Ela começa a abrir o livro.)

MÃE - Ah, agosto ...

Todos olham para o livro.

MÃE (continua a abrir o livro. Ela permanece em sua cadeira) - As férias intermináveis ...

Todo mundo olha para frente, como se pudessem ver as férias intermináveis. MÃE pisa sobre a mesa. $O$ movimento da cadeira espelha o movimento de abertura das páginas. O grupo familiar ajuda a mãe a subir na mesa 
Desse modo, são propostos dois modos de leitura da peça. De um modo, poderíamos ler a transcrição da dramaturgia cênica do espetáculo apresentado pelo grupo inglês - um idioma cênico que se compõe da ação dos atores, dos movimentos e gestos corais, da iluminação, dos jogos visuais descritos nas rubricas (como o espelhamento do movimento da cadeira e do livro) etc. De outro, podemos reescrever a dramaturgia a partir de um fragmento lírico que, vez por outra, interrompe (e redimensiona) a descrição das cenas. Neste caso, o agenciamento deixa de ocorrer apenas entre a imaginação dos espectadores e as lacunas propositalmente deixadas pelo autor (como vimos em Vinaver) e passa também a acontecer entre autor e criadores cênicos (encenadores, atores, iluminadores, etc). Não há mais um texto que gera uma cena, mas uma matriz procedimental (ou seja, com regras particulares e próprias) capaz de gerar inúmeras escrituras cênicas.

É importante diferenciar este formato daquele já discutido anteriormente (e bastante comum) em que encenadores propõem uma interpretação "inédita" ou "inovadora" a um texto clássico. Não se trata, aqui, de uma interpretação ou abordagem nova a um texto dramático, mas da ausência um formato único à dramaturgia. Os elementos da ficção são apresentados como um sitema de "quadros" interconectados ${ }^{81}$ que carregam a potência de arranjos cênicos diversos, a partir de procedimentos particulares à criação.

Este formato dramatúrgico, de modo similar às narrativas hipertextuais, exemplifica o que já foi aqui descrito como autoria procedimental. Essa ideia é melhor descrita nas palavras de Janet Murray:

“(...) o autor procedimental é como um coreógrafo que fornece os ritmos, o contexto e conjutno de passos que serão executados. $O$

\footnotetext{
MÃE - Dias e dias e dias cheios da doce polpa derretida de pêra dourada. E as ginjas maduras que cheiravam muito melhor do quando provadas. As praças douradas pela luz solar no chão de madeira. Um acorde distante jogado em um piano e outro e outro."

81 "O quadro é um eficiente formato conceitual da representação digital de informação qualitativas. O conceito foi primeiramente proposto por Marin Minsky, o influente e controverso pioneiro da inteligência artificial cuja carreira tem sido dedicada a representar a consci6encia humana em termos de estruturas computacionais. Minsky imagina a memória humana como um conjunto de quadros, cada um equipado com 'encaixes' ou 'terminais'. Podemos pensar nesses quadros como blocos de múltiplas faces com conectores de várias cores e tamanhos, semelhantes aos de um brinquedo Lego. Algumas das informações armazenadas nos terminais seriam exemplos específicos deo item para o qual o quadro é uma pura abstração, uma espécie de ideal platônico." (MURRAY, 2003: 198)
} 
interator, seja ele navegador, protagonista, explorador ou construtor, faz uso desse repertório de passos e de ritmos possiveis para improvisar uma dança particular dentre as muitas danças previstas pelo autor. Talvez se possa dizer que o interator é o autor de uma performance em particular dentro de um sistema de história eletrônico, ou o arquiteto de uma parte específica do mundo virtual, mas precisamos distinguir essa autoria derivativa da autoria original do próprio sistema." ${ }^{\prime 22}$

\section{Imersão: dramaturgias híbridas}

Já exemplificados de que forma conceitos como hipertextualidade, agência e autoria procedimental podem servir como instrumento de reflexão poética de textos teatrais contemporâneos, outro paralelo entre as mídias eletrônicas e dramaturgias que merece ser descrito é o conceito de imersão.

J. H. Murray se refere à imersão como a possibilidade oferecida pela ficção de que o leitor/espectador "entre" na narrativa, de que, como num jogo de RPG ou num ARG (alternative reality games), o público possa fundir realidade e ficção. Esse novo espaço, para o público "mais real que a realidade" (nas palavras de Murray ao se referir ao ambiente digital), mostra-se como o lugar propício para que ele interfira na ficção e seja parte integrante da narrativa, já que pode ser ao mesmo tempo imaginário e material (geografias e tempos divergentes inseridas no contexto do real).

Este embate entre realidade e ficção é um dos temas mais presentes nas discussões e experiências da cena teatral contemporânea. Será útil, portanto, observarmos rapidamente a abordagem proposta pela teórica Erika Fischer-Lichte associando-a a alguns exemplos da cena brasileira atual para, então, abordarmos, como exemplo, alguma dramaturgia que se aproprie desta tensão entre os pólos "realidade" e "ficção" em sua composição, objetivando ou abandonar o plano simbólico ou, através da fricção com a realidade, exacerbá-lo (como veremos na dramaturgia do argentino Federico León).

\footnotetext{
${ }^{82}$ MURRAY, 2003; 150
} 


\section{Realidade e Ficção em cena (a partir da análise de Erika Fischer-Lichte)}

Uma atriz que representa a famosa atriz Arkádina ${ }^{83}$, em meio aos discursos sobre a arte dramática da personagem fictícia, cita os espetáculos reais que a tornaram conhecida, misturando sua trajetória artística à da personagem. Um espectador tenta desviar do sangue artificial que desenha as pegadas de um ator nas escadarias de um hospital desativado, para então encontrá-lo realmente pendurado, nu, em uma espécie de pau-de-arara. Uma outra atriz caminha rapidamente, dirigindo-se aos espectadores, falando rápida e ininterruptamente de suas tarefas, descrevendo, entre os inúmeros ensaios e obrigações em que se vê envolvida, sua mais recente tarefa: a decapitação da personagem Maria Stuart ${ }^{84}$. Cinco atrizes perguntam às espectadoras suas datas de nascimento e, enquanto as escrevem com tinta nas janelas do espaço cênico, misturam o tempo atual com o século XIX, tempo ficcional do espetáculo. Essas quatro situações cênicas vistas recentemente na cena teatral brasileira - respectivamente trechos de "A Gaivota: Tema para um conto curto", da Companhia dos Atores, com direção de Enrique Diaz; "O Livro de Jó", do Teatro da Vertigem, encenado por Antônio Araújo; "Rainha[(s)]: duas atrizes em busca de um coração", dirigido por Cibele Forjaz e "Hysteria", do Grupo XIX de Teatro, sob direção de Luiz Fernando Marques - borram as fronteiras entre realidade e ficção, desestabilizando e até mesmo desmoronando essa oposição binária.

Como já vimos na introdução desta dissertação, qualquer evento teatral apresenta uma evidente tensão entre realidade e ficção - de um lado, as tentativas de eliminar a realidade do palco e, por outro, as tentativas de se acabar com a ficção. Vimos também que uma das características determinantes da "performatividade" é o colapso de antagonismos binários como real e ficcional ${ }^{85}$.

Erika Fischer-Lichte, em seu texto "Fictional Realities/Real Fictions" nos aponta dois tópicos de observação da tensão entre o real e o ficcional: a corporeidade dos atores e os espaços cênicos. Nos dois casos, sua análise parte de exemplos da cena európeia recente, o que

\footnotetext{
${ }^{83}$ A Gaivota, Anton Tchekov

${ }^{84}$ Maria Stuart, Schiller

${ }^{85}$ Erika Fischer-Lichte. Explaining Concepts: Performativity and performance.
} 
nos conduzirá a uma observação - embora superficial - de espetáculos brasileiros que também trabalham neste espaço entre extremos.

No que diz respeito ao corpo dos atores, a pesquisadora evidencia a óbvia separação entre o corpo do ator/performer e a personagem ficcional. Ela cita, para desenvolver sua argumentação, o espetáculo "Giulio Cesare" (1998) da companhia italiana Societas Raffaello Sanzio. Segundo sua descrição, Romeo Castellucci colocou em cena corpos frágeis, doentes e excessivos, provocando suspensão e constragimento na platéia. Caesar era interpretado um idoso extremamente fragilizado, quase incapaz de se manter de pé. Antonius era representado por um homem que havia sofrido uma operação na laringe e um microfone tornava audível suas tentativas torturantes de articular uma quase-voz. As duas personagens femininas eram interpretadas por duas performers bulímicas, extremamente magras. Ainda segundo FischerLichte, a fisicalidade (physis) de cada ator tinha um impacto tão imediato e perturbador nos espectadores que eles se sentiam quase incapazes de estabelecer uma relação entre aqueles corpos e a figura dramática que supostamente representavam. O corpo do ator não podia, assim, escapar da percepção do público, escondendo-se atrás de um personagem. Afirmar que era difícil, e até inadequado, perceber e interpretar os corpos dos atores como signos de uma figura dramática particular não quer dizer que os espectadores estavam percebendo-os sem produzir algum significado. Uma vez acostumados com as particularidades desses corpos, o público (que permanecesse no teatro) era, por vezes, capaz de percebê-los como Caesar ou Cícero.

Se pensarmos na cena brasileira, podemos exemplificar este tipo de percepção, isto é, uma divergência entre o corpo do ator e a figura da dramática que ele representa, com o espetáculo "O Livro de Jó" (1995), do Teatro da Vertigem. Seja na total entrega e transfiguração de Matheus Nachtergaele como Jó, nu e exposto à tortura e flagelação, seja na experiência sensorial provocada pela proximidade entre atores e platéia nos corredores de um hospital, os espectadores estavam sempre percebendo "o real" entre as frestas da trágica história bíblica.

Em uma reportagem na Folha da Tarde (junho/1995), entitulada "Peça em Hospital provoca Desmaios", Fernando Oliva afirma: 
"Você pode desmaiar, ficar respingado de "sangue" ou passar mal com o cheiro de éter. Há também a possibilidade de uma crise de choro. Mas nenhum motivo é forte o bastante para deixar de percorrer os três andares do Hospital Umberto I atrás dos atores de O Livro de Jó. ${ }^{\prime 86}$

Neste pequeno trecho, já podemos notar que os espectadores são obrigados a lidar com o fenômeno real - a fisicalidade dos atores colocados em situações de risco, a proximidade com a cena e seu transbordamento para a platéia, a memória e materialidade do espaço - e o ficcional, evidenciado por constantes crises de choro - fruto tanto do envolvimento com a narrativa como pela impressão dos riscos presenciados.

Outras manifestações da crítica teatral também nos revelam como a presença do real, neste espetáculo, é parte fundamental de sua estrutura ficcional, de sua encenação e, portanto, a percepção do público não pode deixar de unir, de forma indissociável, a materialidade à representação :

\begin{abstract}
"Com seus corpos molhados, sujos de sangue, sua encenação temerosa e crivel, seu muco e sua percepção de espaço e som, penetraram no meu coração (...) Talvez não fosse teatro, mas arte-móbile, pois nunca vou me esquecer daquela cena com o Jó atormentado, continuando firme na sua fé, numa prateleira embaixo do teto descascado no segundo andar da maternidade..." 87
\end{abstract}

O Livro de Jó explicita, no teatro brasileiro, a transformação do espetáculo teatral em um "evento" ${ }^{88}$. E exemplifica o lugar de percepções híbridas frente à corporeidade dos atores entre a ficção e a realidade - em que o público vem sendo colocado. Focar nas pegadas que o corpo nu de Nacthergaele deixava nas escadarias significava se esquecer completamente de Jó; focar no sofrimento de Jó e sua mulher impunha que nos "esquecêssemos" do corpo de Matheus, pendurado e em silêncio.

Ainda para falar do corpo dos atores, Erika Fischer-Lichte aponta outras estratégias de valorização do real bastante diferentes, como as utilizadas pelo encenador Frank Castorf.

\footnotetext{
${ }^{86}$ Crítica publicada em Trilogia Bíblica/ apresentaçõa de Arthur Nestrovski - São Paulo - Publifolha, 2002.

${ }^{87}$ Marie Ladie. En Helgen: Frejlif (Dinamarca), outubro de 1997.

${ }^{88}$ Como afirma a crítica Mariângela Alves de Lima: "Em vez de objeto a ser contemplado, há uma experiência de tal ordem que só nos resta aceitá-la ou rejeitá-la como um todo." Mariângela Alves de Lima. O Livro de Jó Põe a Metafísica à prova. O Estado de São Paulo, fevereiro de 1995.
} 
Frequentemente nos espetáculos do alemão, seus atores parecem se esquecer da figura dramática que representam para se dirigir diretamente à platéia, ou ainda parecem não se encaixar no papel (cross-casting). Por vezes, a platéia não consegue ter certeza se é o próprio ator que está se dirigindo a ela, ou se ele assumiu um outro personagem ou se continua a interpretar seu papel (embora de um modo estranho), como em "The Devil's General"(1996), em que o diretor constantemente valoriza as evidências - pela sobreposição de contrastes e divergências - de que uma mulher interpreta o General Harras. No caso dos espetáculos de Castorf, o público geralmente não está apto a dar respostas inequívocas a uma questão como: "é o ator ou o personagem que se dirige a mim?"

Voltando aos palcos brasileiros, poderíamos ainda citar três exemplos bastante recentes, em que os espectadores também não detêm respostas absolutas para questões desse tipo. Nos exemplos a seguir, mais que o corpo dos atores, são suas histórias, trajetórias, impressões e personalidades que saltam aos olhos do público.

Ao entrar na sala de espetáculos onde vai "acontecer" o espetáculo "Aqueles Dois" (2008), da companhia mineira Luna Lunera, o espectador já encontra os atores em cena, realizando pequenas coreografias em duplas ou dizendo trechos de cartas, enquanto também cumprimentam os conhecidos que chegam, indicando assentos. Não podemos precisar em que momento os atores começam a representar seus personagens, já que o jogo de transferência entre conversas dos atores com o público e o desenvolvimento de relações intersubjetivas (diálogos) entre as personagens é constante. O borramento das fronteiras entre o real e o ficcional fica ainda mais evidente quando percebemos que os quatro atores interpretam, por revezamentos e simultaneidades, os dois protagonistas ficcionais: Raul e Saul. É importante dizer que, embora a encenação não eleve ao primeiro plano os procedimentos da teatralidade, o espectador está em constante trânsito entre o depoimento dos atores e a narrativa ficcional ${ }^{89}$. Essa transferência de ordens perceptivas é ainda mais explícita quando, no clímax da relação entre Raul e Saul, os atores abruptamente interrompem a ação para dedicar o espetáculo daquele dia a alguém em particular.

${ }^{89}$ O espetáculo é uma adaptação do conto homônimo de Caio Fernando Abreu. 
Um segundo exemplo é o espetáculo "Rainha[(s)]: duas atrizes em busca de um coração" (2008), escrito a partir das improvisações das atrizes Isabel Teixeira e Georgette Fadel e da diretora Cibele Forjaz sobre "Maria Stuart", de Schiller. Logo no início, as atrizes chegam vestidas em jeans e camiseta - atrasadas e, chamando-se por seus nomes reais, desculpam-se com a platéia enquanto se arrumam para "dar início ao espetáculo”. Desde o início, o público pode suspeitar de que se trata de uma farsa, mas não pode afirmar com precisão que a discussão das atrizes por causa dos grampos de cabelos é uma construção dramatúrgica. Esse pequeno conflito irá aparecer mais tarde quando, já representando a Rainha Elizabeth, Georgette atira os grampos no chão, enquanto lança as palavras de Schiller sobre Maria Stuart. Nesta situação, a platéia confronta a lembrança da disputa supostamente real entre as atrizes e o embate entre as duas rainhas fictícias. A platéia é ainda mais exposta ao caráter "eventual" e real daquela peça quando tem que escolher qual das duas atrizes/personagens irá ser decapitada/fará a cena final.

É interessante notar também como as duas atrizes lidam de maneiras distintas com a realidade em suas performances - enquanto Isabel Teixeira transita entre a conversa casual com o público (explicando, por exemplo, que o figurino que usa - um robe com um dragão nas costas - é uma homenagem a sua avó) e a entrega passional à personagem histórica, expressa na grandiosidade de voz e gestos; Georgette Fadel aproveita-se de sua trajetória de sucesso no teatro paulistano como matriz tanto para compartilhar seu processo criativo com os espectadores como para construir uma Rainha Elizabeth atribulada e confusa. Esse procedimento fica claro na cena em que, carregando muitas bolsas e os figurinos de sua personagem, ela anda pela palco nos contando incansavelmente seus múltiplos compromissos, os ensaios daquele dia, os editais em que se inscreve, as planilhas e os papéis que têm que assinar. A assinatura de papéis abre espaço para, sem transferência no registro da interpretação, que ela discorra sobre a assinatura do documento que autoriza a decapitação de sua inimiga. Aqui, claramente, os universos real e ficcional se unem num mesmo monólogo, sem qualquer indicativo cênico da transferência do discurso da atriz para a fala da personagem. O público, então, é jogado num ambiente de incertezas, um espaço intermediário entre a ficcionalidade da disputa de duas rainhas e a materialidade do jogo de duas atrizes. 
Com procedimentos semelhantes, podemos voltar a citar o exemplo que abriu esta digressão, "A Gaivota: Tema para um conto curto" (2007), da Companhia dos Atores. Já no programa do espetáculo, Enrique Diaz esclarece a simultaneidade e fusão da relação binária discutida aqui:

\begin{abstract}
"Estamos ali com o público e estamos ali com a fábula, com a maravilha simples de Anton. Trocar de personagem sempre que necessário (...) Lembrar que entre o momento em que a peça foi escrita e hoje há todo o século XX. Lembrar que aquele momento era permeado de uma tensão que iria explodir na grande transformação na percepção e expressão humana..."
\end{abstract}

Durante todo o espetáculo, os mecanismos da encenação enfaticamente dirigem nossa atenção ora para a individualidade do ator (corpo fenomenal), ora para as figuras dramáticas da obra de Tchekov. Mariana Lima, conhecida do público teatral por seu trabalho principalmente com o Teatro da Vertigem, mistura sua experiência, descrevendo as peças de que participou, com as falas da personagem Arkádina, também uma atriz. Em outro momento, ela mostra à platéia vídeos reais com gravações dos espetáculos em que atuou, como se fossem trechos dos espetáculos da mãe de Treplev, sua personagem. Embora essas rupturas resultem num desaparecimento temporário da figura dramática - Arkádina -, não podemos considerá-las como dispositivos que fazem desaparecer completamente a ficção, mas antes como estratégias que profundamente "irritam" nossa percepção.

Em todos esses exemplos, nossa percepção oscila entre ator e personagem. Enquanto os dispositivos da encenação (como os descritos) podem dirigir ou até fixar a atenção do espectador no corpo dos atores, a dramaturgia abre a possibilidade de que, por vezes, o foco mude para a figura dramática. Cada vez que essa "oscilação" surge, há uma ruptura, uma descontinuidade. A ordem de percepção que os espectadores construíram é destruída e outra ordem tem que ser estabelecida.

Fischer-Lichte descreve duas ordens de percepção coexistentes neste processo: $a$ ordem de representação e a ordem de presença. No primeiro caso, tudo o que é representado é

\footnotetext{
${ }^{90}$ Enrique Diaz, programa de A Gaivota, em apresentações no SESC Pinheiros.
} 
percebido em referência a um personagem ficcional. O processo perceptivo é, então, guiado pela intenção de se deixar uma figura dramática vir a existir. Elementos percebidos que não puderem ser associados à ficção não serão considerados no processo de geração de significados.

Sabemos, porém, que inevitavelmente algum elemento irá desestabilizar esse esquema perceptivo. A ordem da representação será perturbada e outra ordem irá emergir, mesmo que temporiamente. E então, somos transferidos até outra percepção: $a$ ordem de presença. A presença pressupõe que o corpo do ator seja percebido em sua materialidade - quando esta ordem se estabiliza temporiariamente, o processo de percepção e geração de sentido se torna absolutamente imprevisível e caótico. A dinâmica do processo perceptivo define que nenhuma dessas ordens é capaz de se estabilizar permanentemente. Neste constante intercâmbio em busca de estabilização, ganha relevância o momento de instabilidade e mudança, o limiar - em que uma ordem de percepção é alterada, mas outra ordem ainda não está estabelecida.

Já no que diz respeito ao borramento das fronteiras entre espaços reais e ficcionais, Erika Fischer-Lichte usa como primeiro exemplo, a "instalação" de Grüber, Rudi (1979), que acontecia em um hotel bombardeado durante a guerra.

Livres pelo espaço real do hotel, os espectadores podiam se mover aleatoriamente por todos os quartos, preparados com objetos cênicos, ocupados por atores-objetos e sonoramente preenchidos pela leitura do texto que inspirou a obra. Sem dúvida, os espaços do hotel Splanade eram reais; os objetos cenograficamente dispostos nos ambientes também eram reais. Havia, por outro lado, uma história ficcional que era lida por um ator. Justapostos, esses elementos reais e ficcionais poderiam apenas vagamente (se podiam) ser associados. Embora agindo como visitante de um museu, o espectador não era capaz de "recontar" uma narrativa $^{91}$ a partir da ordenação imaginária dos objetos, espaços e palavras; os espaços performativos apresentados ao espectador o colocavam num lugar "intermediário", em que os pares teatro/museu, espectador/visitante, narrativa literária/história alemã, atores/objetos operavam simultaneamente.

\footnotetext{
${ }^{91}$ The Birth of The Museum (1995), de Tony Bennet
} 
O segundo exemplo de Fischer-Lichte é o "audio-tur" de Stefan Kaegi (um dos fundadores do coletivo Rimini Protokoll ${ }^{92}$ ), Hygiene Heute (2000) ${ }^{93}$, que aconteceu em diferentes cidades européias. Ao público, era fornecido um walkman em que a fita ouvida seria, ficcionalmente, o último sinal de vida do personagem Kichner. Orientado pela narração da "voz ficcional", o público era colocado como protagonista de uma história detetivesca. Andando pelo espaço real da cidade, era difícil para o atuante/espectador identificar se em determinada estação de metrô, por exemplo, havia atores, ou se estava imaginando que as pessoas às quais a voz se referia eram personagens. Nesse processo, ele era obrigado a olhar sua cidade real com outra percepção.

Nestes dois exemplos, a fusão entre o espaço ficcional e real é bastante clara: um hotel real que é "rearranjado" cenograficamente e a cidade real "rearranjada" imaginariamente pelo espectador/atuante.

De volta à cena brasileira, parece inevitável citarmos mais uma vez os espetáculos do Teatro da Vertigem. Silvia Fernandes comenta, no texto "O Lugar da Vertigem" sobre a materialidade do espaço em O Livro de Jó:

\begin{abstract}
"Pautado em quadros autônomos, interligados pelo protagonista, apontava para o trabalho de regulação espacial planejado por Araújo no Hospital Humberto Primo (zona central de São Paulo), organizando o enredo numa trajetória ascensional que reforçava a passagem para o final transcendente, ambientado na sala de cirurgia. (...) Poucas vezes vivi um desconforto semelhante ao dessa cena, que mergulhava o espectador numa experiência radical. Dividindo o espaço em duas fileiras de arquibancadas, a mesa de cirurgia formava uma espécie de palco-sanduiche, destacado por uma luz cegante dirigida a Jó, deitado, e ao público sentado a seu lado. As portas trancadas, o cheiro de formol, a impossibilidade de olhar para o ator sem ver, ao mesmo tempo, como que formando um ciclorama humano, os espectadores sentados na frente, criavam uma relação teatral inédita $e$
\end{abstract}

\footnotetext{
${ }^{92}$ A trajetória deste grupo, que associa os trabalhos de Stefan Kaegi, Helgard Haug e Daniel Wetzel mereceria um destaque, já que trabalha exatamente na fronteira entre a realidade e a ficção. Dois espetáculos de Kaegi, que ampliam essa tensão de formas inéditas, foram apresentados no Brasil: Torero Portero e Chácara Paraíso.

Mais detalhes em: http://www.rimini-protokoll.de/website/en/about_sk.html

${ }^{93} \mathrm{http} / / /$ www.hygieneheute.de/
} 
transformava o público numa comunidade cúmplice, solidária naquele espaço da cura e da morte." ${ }^{\prime 94}$

Em Apocalipse 1, 11 (2000), o diretor utilizava o presídio do Hipódromo como o espaço real em que se desenrolava a trajetória do personagem bíblico João. Mais uma vez, vale a pena citar Sílvia Fernandes:

\begin{abstract}
"No espetáculo, Antônio Araújo criava ambientes distintos, aproveitando as celas, os pátios, os corredores, as grades, os muros e a entrada do presídio para organizar uma frenética e aterrorizante movimentação processional, exacerbada pela interpretação tensa dos atores e pela sonoplastia agressiva. (...)permitia experimentar fisicamente o tema tratado e o colocava numa zona fronteiriça, entre o teatro e o espaço real do presídio." 95
\end{abstract}

Tanto em 0 Livro de Jó como em Apocalipse 1,11, o Teatro da Vertigem se insere em ambientes reais e os modifica, os adapta em função da ação ficcional. Nesse sentido, há um tratamento estético do espaço real, num trabalho de composição cênica a partir de espacialidades muito particulares (por exemplo, o painel de radiografias e a reutilização de materiais cirúrgicos ou as luzes que construíam a Boate New Jerusalem e transformavam uma cela no quarto da Noiva). Essa "cenografização" do espaço real acaba por guiar ainda mais a percepção do público em direção ao "caráter de realidade" do espaço em que a dramaturgia se insere, à ordem de presença daquela narrativa ficcional. Estratégias bem diferentes podem ser notadas no trabalho com espaços reais em um espetáculo mais recente da Vertigem, "BR3" (2005), e em "Hygiene (2005)", segundo espetáculo do Grupo XIX de Teatro, em que o espaço cênico é a própria cidade.

Em $B R-3$, instalado num barco que navega pelo Rio Tietê, o público excursiona às margens da cidade de São Paulo, acompanhando personagens de identidades móveis, cuja ação dramática acontece em diversos pontos do território brasileiro. É o próprio Antônio Araújo quem explica a relação de instabilidade e confronto dos espectadores com a presença indelével do Rio Tietê e a dramaturgia épica de Bernardo Carvalho:

\footnotetext{
${ }^{94}$ Sílvia Fernandes. O Lugar da Vertigem. Trilogia Bíblica. p. 37

${ }^{95}$ Silvia Fernandes. O Lugar da Vertigem. Trilogia Bíblica p. 39
} 
"Existe um jogo de precipitações e fluidificações que é, talvez, para onde essa discussão caminha. E, nesse sentido, o espaço do rio ajuda muito, porque você não tem terra firme, está sempre móvel, num barco que balança e é instável. (...) A idéia é que as cenas de Brasília, dentro do percurso, sejam ligadas ao monumental e aos viadutos -o Cebolão, a ponte CPTM e o viaduto Anhangüera. Brasilândia acontece debaixo das pontes - Atílio Fontana e dos Remédios. Ao ar livre, nas margens, a gente vai ter Brasiléia. A outra idéia de ocupação espacial é de que tudo que for meio de transporte ou cena de passagem e de movimento seja feito em barcos em movimento - um barco-ônibus, um barco-avião, por exemplo. Além disso, os dois irmão, Patrícia e Douglas, vão estar em margens opostas do rio, e a trajetória deles vai se dar sempre em margens opostas. ${ }^{\prime 96}$

Ao localizar o espetáculo no rio Tietê, Araújo obriga o espectador a se confrontar com os riscos e manifestações reais envolvidos na apresentação, dilatados ainda mais pelo estado de deterioração do rio. Cada um dos espectadores encontrava-se, indiscutivelmente, num trânsito de percepções, entre a ficção proposta pelo dramaturgo e as garrafas pet, adereços de escola de samba, cães e ratos mortos ${ }^{97}$ que boiavam no rio; entre o concreto dos viadutos e uma Brasília imaginária; entre as pontes paulistanas e a representação de Brasiléia. Ainda percebemos uma intervenção cenográfica, mas a arquitetura da cidade é colocada em primeiro plano, a cena se utiliza dos espaços reais para se referir ficcionalmente a outras cidades, para criar "lugares de desvio." 98

Em Hygiene, o Grupo XIX ocupa a Vila Maria Zélia, na cidade de São Paulo - vila fundada em 1917, com creches, escolas, capela e salões de baile, tombada como patrimônio público em 1992. Já na abertura do registro dramatúrgico publicado deste espetáculo ${ }^{99}$, encontramos a seguinte observação:

"O Grupo XIX de Teatro criou a dramaturgia de Hygiene em harmonia com a espacialidade da Vila Operária Maria Zélia, Belenzinho, São Paulo-SP, onde foi originalmente encenada. Por entender o espaço

\footnotetext{
${ }^{96}$ Entrevista de Antônio Araújo, realizada em outubro de 2005 e publicada em BR-3, de Sílvia Fernandes e Roberto Audio.

${ }^{97}$ Segundo depoimento da equipe técnica e criativa do espetáculo, registrados no livro $B R-3$.

98 Termo utilizado por Sílvia Fernandes, dramaturgista de BR-3, em "Cartografia de BR-3". "Filtrados pelo olhar coletivo e defromados por essa modalidade contemporânea de representação, fragmentária e explodida, tornamse lugares de "desvio", irreconhecíveis em sua identidade original." p. 43.

${ }^{99}$ Hysteria/Hygiene. Grupo XIX de Teatro
} 
cênico como um personagem, as rubricas aqui citadas referem-se à arquitetura e desenho urbano encontrados na Vila. Porém, o texto está aberto para sofrer as interferências que cada novo espaço de encenação pode trazer para esta dramaturgia." ${ }^{\text {100 }}$

Não convém questionar se o espaço é realmente um dos personagens da encenação, mas ao afirmar isso, o grupo propõe uma fusão do espaço real com o espaço ficcional. É importante dizer que, entre as ruínas abandonadas e casas reformadas da Vila Maria Zélia, encontramos um espaço real que nos carrega até o passado e nos expõe materialmente a história da cidade de São Paulo (como o Hotel Splanade, em Grüber, remetia à história alemã).

O público, como em Hysteria, primeiro espetáculo do grupo, é lançado em um universo imersivo em que simultaneamente atua como convidado de um casamento no Rio de Janeiro de 1899 e espectador de um espetáculo teatral em uma vila operária de São Paulo em 2005.

Embora tenhamos a impressão de que, no caso de espetáculos imersivos como Hygiene, o foco da percepção concentre-se no ambiente ficcional, o jogo com o ambiente e os atores reais precisa ser evidenciado para que o espectador aceite o "pacto ficcional". Ao atuarem nas varandas de casas habitadas, tocarem o sino da igreja ou utilizarem como dramaturgia as respostas da platéia à interação, os atores sublinham a presença da cidade, da arquitetura e da história daquele ambiente e questionam a relação espectadores/atores - uma das polaridades necessárias à estabilização da ordem de representação.

Podemos ressaltar outros casos de valorização do par realidade/ficção, como a divergência entre o tempo real e o tempo ficcional presente no espetáculo Hysteria (particularmente na cena em que as atrizes contrapõem o ano de nascimento das espectadores ao contexto ficcional em que estão imersas); ou os espetáculos/performances do grupo Rimini Protokoll , que aproximam a cena do documentário ao colocarem não-atores em situações cênicas (como em Torero Portero ${ }^{101}$ - em que a platéia olhava para a cidade real, emoldurada por um vidro, enquanto ouvia os relatos de porteiros reais - ou em Chacára Paraíso ${ }^{102}$ - em

\footnotetext{
${ }^{100}$ Hygiene. P. 07

${ }^{101}$ http://www.rimini-protokoll.de/website/en/project_406.html

102 http://www.rimini-protokoll.de/website/en/project_2445.html
} 
que policiais reais interagem com a platéia); ou a suspensão criada por Renato Cohen e Peter Pal-Pálbert nas performances do Coletivo Ueinzz, em que pacientes de um hospital-dia se integram à cena.

Em todos os exemplos deste texto, o borramento entre o real e o ficcional (com as particularidades de cada um dos casos), resultaram numa transferência do espectador/visitante para um estado intermediário, entre extremos, em que não é possível catalogar espaços, corpos ou tempos como reais ou ficcionais. O mesmo acontece quando estamos imersos no ambiente digital.

Essa fusão entre o universo ficcional e a realidade é um dos fundamentos de um ambiente imersivo. Tal conceito nos serve então para pensar muitas das encenações atuais. Mas e o texto teatral? De que forma essa friç̧ão de polaridades interfere especificamente na dramaturgia textual?

\section{Realidade e ficção no texto teatral}

Antes de responder é essa pergunta, é necessário lembrar que qualquer análise de dramaturgia contemporânea deve envolver um entendimento da cena derivada dela (ou da escritura cênica que resultou em um texto), já que, segundo Lehmann, uma das características definidoras do "teatro pós-dramático" seria a parataxe, ou seja, a des-hierarquização dos recursos teatrais - em particular entre texto e cena. ${ }^{103}$

A ideia de uma realidade que emerge no próprio texto teatral parece uma ideia abstrata, já que a dramaturgia convencional (que não descreve, como roteiro, uma performance) normalmente instaura um universo diegético (ficcional). Mesmo que não se constitua propriamente uma fábula, ainda assim, o texto se refere a uma ordem de representação. Poderíamos dizer que uma irupção do real talvez aparecesse no texto na forma de convenções que incluem a audiência, como os apartes e apóstrofes dirigidos a ela. Ainda

${ }^{103}$ LEHMANN, 2007: 143-145 
assim, por vezes essas irritações aparecem emolduradas por um cosmos fictício que reduz o seu impacto e as inclui no artifício. ${ }^{104}$

De um modo bem diferente, mostram-se irupções de real em algumas outras dramaturgias contemporâneas. De um lado, a realidade pode emergir no texto teatral na elevação ao primeiro plano de formas infiltradas em sua estrutura, como as didascálias tornando-se voz de personagens ou fragmantos textuais que garantem a "novelização" do texto dramático, ${ }^{105}$ isto é, a contaminação do diálogo por qualidades narrativas. Parte do discurso dramático tradicionalmente atribuído aos personagens é substituído por um tipo de linguagem alheio à troca dialógica comum, incluindo narrações nas próprias falas das personagens primeira e terceira pessoas habitam uma mesma fala e operam simultaneamente. Poder-se ia afirmar que tal recurso deriva do teatro épico brechtiano. Ryngaert, porém, diferencia as duas propostas:

"Esse teatro [o teatro épico], no entanto, sempre transitou, para trás e para frente, entre os momentos de diálogo e os momentos verdadeiramente épicos - palavras dirigidas ao público, canções, $e$ assim por diante - claras indicações a cada mudança na natureza do próximo momento. Hoje, pelo contrário, embora não se possa detectar qualquer sinal de uma intenção política ou mesmo de uma consciência épica, os personagens pertencem a uma forma mais ou menos evidente de ficção, por vezes, adotando uma forma narrativa de falar ou de se dirigir ao público diretamente. $O$ dramatis personae, assim, passou a incluir todas as formas de narradores, recitadores, monologistas, narradores e repórteres - todos os tipos de mediadores entre a ficção eo público." 106

É evidente então que aquela irritação em ordens de percepção descrita por FischerLichte passa a acontecer também na fisiologia do texto teatral. Como resultado desse processo,

\footnotetext{
${ }^{104}$ Lehmann, 2007:.163.165

105 RYNGAERT, 2008: 19. [termo empregado por Bakhtin e teorizado por Sarrazac, segundo citação de Ryngaert]

${ }^{106}$ Tradução livre a partir de: "That theater [o teatro épico], however, always shifted back and forth between moments of dialogue and genuinely epic moments - words addressed to the audience, songs, and so on - and clearly indicated each change in the nature of the next. Today, by contrast, although one cannot detect any sign of a political intent or even of an epic consciousness, characters belonging in a more or less evident way to fiction sometimes adopt a narrative way of speaking or address the audiency directly. The dramatis personae thus come to include all manners of narrators, reciters, monologists, storytellers, and reporters - all manner of mediators between the fiction and the public." (RYNGAERT, 2007: 19)
} 
temos dramaturgias híbridas que se comunicam em mais de um nível com o público - nem só diegético e nem só no campo da materialidade.

De outro lado, temos dramaturgias que utilizam a vida de seus criadores como matéria para a ficção. Poderíamos citar os relatos autobiográficos do performer Spalding Gray ou ainda os "arquivos" de uma das diretoras de teatro experimental mais reconhecidas da Argentina, Vivi Tellas. Ela trabalha há anos colocando o teatro em contato com outros mundos, rastreando elementos teatrais (a repetição, a presença, a situação, o olhar dos outros, o texto) em vidas, situações ou disciplinas exteriores ao teatro. Parente do gênero documentário, o seu teatro não repousa na representação mas na apresentação de "casos". Seu trabalho gira em torno de uma ideia: buscar teatralidade fora do teatro. Fez quatro obras que ela denomina "arquivos". O primeiro deles, Mi mamá y mi tía (2003-2004), era uma espécie de retrato baseado nas histórias que Tellas escutava - contadas sempre da mesma maneira - desde pequena. As intérpretes da obra eram sua mãe e sua tia verdadeiras (nenhuma delas atriz) que exibiam em público a história familiar. Seguiram-se mais três obras: "Três filósofos com bigodes", "Cozarinsky e seu médico" e "Auto-Escola" Em todas suas dramaturgias está presente o que ela denomina Umbral Mínimo de Ficção (UMF). ${ }^{107}$ Neste caso, o material diegético do texto é real, sendo reorganizado e emoldurado dramaticamente.

O conceito de imersão, entendido metaforicamente, como um espaço em que a audiência pode transitar entre a ficção e a realidade, pode também ser exemplificado através do espetáculo Museo Miguel Ángel Boezzio, do dramaturgo argentino Federico León.

León (1975-) escreveu e dirigiu os espetáculos Cachetazo de Campo, Museo Miguel Ángel Boezzio, Mil quinientos metros sobre el nivel de Jack e El adolescente, além de alguns roteiros de cinema. Por seus trabalhos, obteve diversos prêmios e tem obtido grande sucesso e

\footnotetext{
107. “Al despojar a todos los elementos que allí intervienen de ficcionalidad, y al profundizar la cualidad presentacional en el trabajo con los protagonistas, el espectáculo juega en el límite de la representación. El marco (la sala de teatro) le provee la teatralidad que termina de configurar el hecho al que asistimos como teatro. Pero extrapolado e esa situación, de ese espacio ya de por si significante, ¿sería teatro? La directora se pregunta, al respecto: “¿En qué momento la realidad empieza a producir ficción? Hay un umbral donde se registra ese pasaje: es el UMF (umbral mínimo de ficción). Detectarlo es el primer paso del trabajo."” Daniela Martin. Ficciones indisernibles.

Para maiores informações sobre os "arquivos" de Vivi Tellas: www.archivotellas.com.ar
} 
repercussão internacional desde 1999. Em seu texto/espetáculo de 1998, Museo Miguel Ángel Boezzio,

"Federico uniu a ideia de museu à ideia de pessoa, enxergando a condição deste espaço que dá suporte ao passado, do que já se foi, lugar de todo ex. Neste ex-lugar, ele colocou um veterano das Malvinas e ex-ator, a mesma pessoa que dá título à proposta, e oferece uma espécie de conferência em que seu próprio passado tornase uma peça do museu." 108

O dramaturgo trabalhou com o contexto real de Miguel Ángel Boezzio, um ex-piloto que, depois da Guerra das Malvinas, permaneceu onze anos internado em um hospital psiquiátrico. Através de uma forma dramática que simula uma conferência (ou uma palestra), Boezzio utilizava como material de exposição seu próprio passado - um procedimento similar ao empregado em um museu -, dando valor exagerado a pequenos acontecimentos de sua vida. Todos os objetos exibidos apontavam para um triunfo mas, contextualizadas como passado real, adquiriam um valor de derrotas: "derrotas exhibidas como si fuesen trofeos."109 Boezzio recebia o público, entregava os programas do espetáculo, fechava a porta do teatro e começa sua conferência sobre si mesmo. Sobre esse espetáculo, León afirma:

\begin{abstract}
"La idea era que la obra fuese una construcción de Miguel, que yo desapareciera, que fuera un trabajo aparentemente autónomo, que no necessariamente coincidiera con mis gustos. Que los tiempos y el criterio de puesta fuesen los tiempos y el criterio de puesta de Miguel. Al final se iluminaban las paredes del teatro y podían verse pegados todos los diplomas, documentos, fotografias que Miguel había exhibido. Al mismo tiempo se oía una conversación entre Miguel e yo, una grabación-registro de los ensayos, que daba cuenta de cómo habíamos construído el espectáculo. (...) ${ }^{110}$
\end{abstract}

\footnotetext{
${ }^{108}$ TELLAS, Viviana. Clarín Espetáculos. 01 dezembro de 1998.

Tradução livre a partir de: "Federico unió la idea persona con la idea museo analizando la condición de este espacio que lo hace soporte del pasado, de lo que ya fue, de todo lo ex. En ese lugar de lo ex colocó a un ex combatiente de malvinas y ex actor, la mismo persona que da título a la propuesta, y que ofrece una surte de conferencia en la que su propio pasado pasa a ser la pieza del museo."

${ }^{109}$ LEON, Federico, Registros: Teatro Reunido e Otros Textos - Buenos Aires, Adriana Hidalgo Editora, 2005.

${ }^{110}$ Federico Leon, idem.
} 


\title{
O deslizamento entre ordens de percepção que se espera de um espaço imersivo
}

evidencia-se, nesta dramaturgia, na seguinte declaração de Federico Léon, acerca daquele espetáculo:

\begin{abstract}
"'O público estava iluminado do mesmo modo que Miguel $e$, portanto, fazia parte da experiência. A plateia acaba por se igualar ao cenário, também deixando exposto o espectador. O que interessava er ao lugar do público. Se o público ria de Miguel pela valorização excessiva que ele dava a acontecimentos aparentemente insignificantes (diplomas, fotografias, notas, poemas, etc) ou se o respeitava em silêncio e nesse sentido era solene. Por outro lado, questionavam-se os limites e as tensões entre a realidade e a ficção, $o$ que pode e o que não pode ser ficcionalizado"111
\end{abstract}

Mais tarde, veremos como essa ficcionalização da realidade aparece e determina a criação do espetáculo "Escuro".

\footnotetext{
${ }^{111}$ Federico Leon. Idem ibidem.

Tradução livre a partir de: "El público estaba iluminado al igual que Miguel y de esta manera formaba parte de la experiencia. La platea quedaba igualda con el escenario dejando expuesto también al espectador. Lo que planteaba Museo Miguel Ángel Boezzio era qué lugar ocupaba el espectador. Si se reía de Miguel por la excesiva valoración que él le daba a acontecimentos aparentemente insignificantes, sumamente importante bajo su mirada (diplomas, fotografias, notas, poemas, etc.) O si respetaba en silencia y ese respecto era solene. Por otro lado cuestionaba los límites y tensiones entre realidad y ficción; lo que que puede e lo que no puede ser ficcionalizado."
} 


\section{PARTE III - MAPA DRAMATÚRGICO:}

“ESCURO”

\section{Outros Paralelos}

Definidos e exemplificados os conceitos, podemos agora descrever o processo criativo do mapa dramatúrgico "Escuro", escrito e criado por mim, de novembro de 2008 a fevereiro de 2010, em processo prático e colaborativo com dez atores. Durante o período de ensaios, foi criado um mapa dramatúrgico a partir de trajetórias de personagens. A manipulação e o agenciamento deste mapa resultou em um espetáculo.

O espetáculo Escuro apresentava uma fábula simples em que a deficiência servia de metáfora para a insuficiência do diálogo. Não se tratava de apontar o "diferente", nem mesmo procurava a sensibilização social do público diante da diferença. Ao contrário, a peça buscava, ao perguntar como se organizaram no homem as possibilidades de conhecimento do mundo, ou de que modos o cérebro processa conhecimento e percepção do real, contar uma história sobre pessoas comuns, sua inadequação, sua linguagem, os hiatos entre suas relações.

Partia-se de uma fábula simples, estruturada como uma narrativa caleidoscópica, para se criar um texto teatral que pudesse ser uma matriz de cenas e não apenas um registro de uma encenação. O espetáculo estreou em novembro de 2009 no SESC Pompéia, realizando, em 2010, com alguns agenciamentos e escolhas diferentes, sua segunda temporada no TUSP. Finalmente, o espetáculo é convidado a participar da Mostra Oficial do Festival de Curitiba 2010.

Ao analisar o processo criativo que resultou neste mapa dramatúrgico, os conceitos estudados passam a servir como matéria-prima criativa e determinam as escolhas estruturais 
do texto teatral. Outra vez, devemos ressaltar que o transporte entre termos técnicos da ciência de comunicação são usados apenas como metáforas para uma proposição artística.

Neste sentido, podemos reconhecer na forma desta dramaturgia uma semelhança com os formatos hipertextuais. O texto teatral é apresentado como um mapa enciclopédico, em que há inúmeras formas de leitura. Poder-se-ia optar por uma leitura de trajetórias individuais, ou totalmente fragmentária (como um roteiro cinematográfico multitrama) ou ainda com deslocamentos temporais e reorganização de perspectivas de uma mesma cena. Ainda podemos falar de "autoria procedimental" ao entendermos como a sobreposição de cenas no espaço determina diferentes leituras da peça. Outro paralelo possível é reconhecer o conceito de "imersão" na unidade temporal e espacial da fábula proposta, na estrutura dos diálogos sem dupla-enunciação ou no hibridismo de linguagem proposto, em que rubricas e narrativas em terceira pessoa tornam-se diálogos.

Discute-se aqui, então, uma dramaturgia criada coletivamente e que, por seu caráter enciclopédico, procedimental, participativo e espacial ${ }^{112}$, é matriz de inúmeras reorganizações dramáticas e possíveis encenações.

\section{A fábula}

O processo de criação exigiu que cada ator criasse uma trajetória individual para seu personagem, fazendo-o cruzar com todos ou alguns dos outros personagens criados, dentro de um contexto ficcional pré-definido por mim: um clube atlético no fim da década de 1950. Foram criadas, então, dez trajetórias de personagens que poderiam ser reorganizadas como um mosaico.

Em uma estrutura dramatúrgica que se alterna entre várias vidas, sem que nenhum personagem surja como protagonista, "Escuro" percorre dez trajetórias de personagens que

\footnotetext{
${ }^{112}$ Segundo J.H. Murray, essas são as quatro características fundamentais do ambiente digital.
} 
têm, em comum, formas diferentes de se enxergar o mundo, a partir de um crise ou deficiência na linguagem. Essa estrutura narrativa coloca em perspectiva um complexo mundo de relações, como se olhasse de cima o emaranhado de conexões quase-invíseis entre as pessoas. Os personagens, quando observados neste ponto de vista, são complexificados e, na convergência de suas histórias, somos levados a pensar em casualidade, adequação e paralelismo; somos forçados a traçar linhas entre as histórias, ou seja, transformamos imagens em narrativas.

O ponto de convergência dessa dramaturgia caleidoscópica é a trajetória de um menino míope que passa as tardes mergulhando na piscina do clube. De pouca fala, escondido atrás de seus grandes e pesados óculos, ele possui uma estranha capacidade de ouvir - em sua presença, quase como resultado de um efeito químico, como a imagem que só se torna visível no papel ao ser exposta à ação do ácido indicado, os adultos se põem a falar. Ele não faz nada em particular: não pergunta, ou interroga com o olhar por detrás dos pesados óculos, ou se interessa. Eventualmente, se vê alarmado com o gesto de desgosto, a expressão sombria ou o brotar das lágrimas com que o outro delata o calvário que está atravessando. Assim que o menino repousa os óculos na beira da piscina e se prepara para o mergulho, repentinamente alguém se aproxima dele, um adulto, desconhecido ou não, cuja sombra imensa vê, primeiro, pairar sobre o azul serpenteante da piscina, e que termina anuviando o céu com uma promessa de tormenta. $\mathrm{O}$ adulto sente necessidade de ficar na mesma altura que ele, ajoelha-se, acomoda-se a seu lado e se põe a contar segredos. Todas as tardes de verão, ele veste o calção por debaixo da roupa e vai até a piscina do clube. Retira os óculos, e ameaça entrar na água, mesmo que não o consiga fazer sem a presença do pai.

Enquanto isso, uma costureira desquitada e sua cliente, uma senhora cujo marido está participando da construção de Brasília, resolvem aprender a nadar para fugir de suas vidas insípidas. As duas treinam em tigelas de água na cozinha de uma delas enquanto se preparam para uma visita a uma piscina de verdade. De mãos dadas, elas seguem caminhando pela rua até o clube.

Outras narrativas que se desenvolvem paralelamente são: uma secretária sonha em participar de um concurso de canto, enquanto é rejeitada pelo dono do clube, por quem é 
apaixonada; o dono do clube, por sua vez, está perdendo as palavras e mal consegue organizar seus pensamentos e sua fala; também afásica é uma das visitantes do clube, que participa de todas as atividades esportivas e esforça-se para se aproximar do fotógrafo da cidade; ele, mudo, só tem as fotografias para expressar um amor abandonado no passado. Há ainda a locutora dos avisos do clube que, cega e iludida, passa a acreditar que tem um admirador secreto.

A última das narrativas convergentes é inspirada na relação da escritora inglesa Helen e sua preceptora, Annie Sullivan com perda gradativa da visão. Helen Keller, cega, surda e muda desde bebê, apenas de posse do sentido do tato e de uma perseverança impressionante, sob a orientação de Anne Sullivan Macy, pôde aprender a ler e escrever pelo método Braile, chegando mesmo a falar, por imitação das vibrações da garganta de sua preceptora, as quais captava com as pontas dos dedos. O esforço de sua mente em procurar se comunicar com o mundo resultou no afloramento de uma inteligência excepcional, considerada ainda a maior vitória individual da história da educação. A noiva do dono do clube prepara sua aluna - uma, também jovem cega-surda desde a infância - para um torneio de natação destinado a deficientes visuais. A irmã está diante da realização de um sonho para o qual tem se dedicado exaustivamente. Em uma relação de espelhamento mudo e de diálogos de mãos, as duas irmãs dedicam-se à preparação para o torneio.

O lugar que une as histórias - desses personagens que carregam os nomes de seus atores - é um clube esportivo - um desses clubes, com piscinas públicas lotadas com os primeiros sopros quentes do ano. Na piscina deste clube, que tem polvos pintados nos azulejos do fundo, acontecerá uma pequena competição entre deficientes visuais. Neste contexto, encontramos os personagens da peça convergindo para essa piscina, cruzando-se, tentando estabelecer ligações apesar dos problemas de linguagem e comunicação.

Como foi dito, o elo entre todos os personagens é o menino míope que ouve segredos. Entre um mergulho e outro, ele cruza com as personagens, ouve suas histórias e funciona estruturalmente como ponte aglutinadora de todos os conflitos. Pressionados por uma mesma ameaça (a chuva) e participando de um mesmo evento (o torneio de natação), as histórias se 
unem, se entrecruzam. Todas as personagens possuem um mesmo e comum sentimento - o medo da chuva que se aproxima e pode destruir os planos traçados por eles: a participação no torneio, a fuga daquele lugar ou o primeiro mergulho numa piscina de verdade.

O menino deixa os óculos caírem no fundo da piscina, bem perto do polvo no azulejo. Uma das amigas experimenta a felicidade de colocar os pés na água no exato momento em que a secretária pede que os visitantes abandonem a piscina em função do torneio. Um trovão anuncia a chuva próxima. O menino mergulha até o fundo para pegar seus óculos, mas não os encontra, não consegue enxergar direito - pelo cloro da água e por sua miopia. Acaba por afogar-se. A tempestade finalmente chega. Debaixo da chuva, imóveis, todos eles compartilham essa pequena tragédia.

Minimamente estruturadas as personagens, a partir das escolhas e depoimentos pessoais dos atores (em processo que será posteriormente descrito), e definida cada trajetória como um diagrama particular, iniciou-se um processo de composição e cruzamento de histórias, tendo como referência alguns roteiros multitrama.

\section{Narrativas em rede}

David Bordwell, no sétimo capítulo de Poetics of Cinema, ${ }^{113}$ afirma que a "dramaturgia multiplot" tem como precursor o drama renascentista inglês (frequentemente com três ou quatro linhas de ação que se interseccionam) e outras narrativas literárias. Entretanto, ele afirma, não há precedente mais popular deste modelo dramático do que a ficção seriada e as "soap operas" televisivas.

Séries como "Hill Street Blues" (1981-1987) - em que acompanhamos dezessete personagens regulares cujas histórias se convergem através de um distrito policial - fizeram com que o público se acostumasse a acompanhar narrativas com vários protagonistas,

\footnotetext{
${ }^{113}$ BORDWELL, David. Poetics of Cinema. "Mutual Friends and Chrnologies of Chance"
} 
detentores de objetivos diferentes, com histórias pessoais que se desenvolvem paralelamente - às vezes sem qualquer cruzamento, ou com cruzamentos casuais, ou ainda conexões bastante sutis. A esse tipo de dramaturgia, Bordwell chama de "network narratives" literalmente "narrativas em rede".

"Assim A encontra $B$, e então $C$, depois $D$. B e e $C$ já se conheciam. Através de $C$, conhecemos $E$, e através de $D$ conhecemos $F$ - mesmo que $A$ não os conheça. O filme revela uma estrutura de conhecimento, parentesco e amizado além do conhecimento de cada personagem. A narração gradualmente nos revela a matriz, nos aproximando de um personagem, depois de outro. $E$ as ações que saltam desta estrutura social não são baseadas em estreita causalidade. Os personagens, embora unidos, tem propósitos e projetos diferentes, e estes se interseccionam apenas ocasialmente - frequentemente acidentalmente (...) Este tipo de trama já foi chamado de 'threadstructures', e os filmes ficaram conhecidos como contos de vidas que se cruzam, fatos convergentes ou 'a rede da vida'. De qualquer forma, eu os chamo de 'narrativas em rede'.114

Mas que modelos dramáticos governam esse tipo de narrativa em rede? Os roteiros multitrama tem algumas características recorrentes, além da multiplicidade de personagens e objetivos: convergência de dramaturgias; a causalidade é substituída pelo acaso ou por espelhamentos; paralelismos (comparações e contrastes de núcleos de personagens distintos) e uma tensão evidente entre artifício e realismo.

Para exemplificarmos coerentemente, podemos recorrer ao drama renascentista de Shakespeare. Em "A Tempestade", última peça do inglês, por exemplo, encontramos pelo menos sete protagonistas: o mago Próspero, sua filha Miranda, o duque traidor Antônio, os seres sobrenaturais Calibã e Ariel e os bêbados Trínculo e Estéfano. Todos esses personagens apresentam objetivos bastante distintos e, embora Próspero seja o centralizador de todos os

\footnotetext{
${ }^{114}$ Tradução livre a partir de: "So A meets $B$, then $C$, then $D$. B and C already know each other. Through $C$ we get to meet $E$, and through $D$ we get to meet $F-$ even though $A$ doesn't know them. The film opens up a social structure of acquaintance, kinship, and friendship beyond any one character's ken. The narration gradually reveals the array to us, attaching us to one character, then another. And the actions springing from this social structure aren't based on tight causality. The characters, however they're knit together, have diverging purposes and projects, and these intersect only occasionally - often accidentally. (...) This sort of plot pattern has been called 'thread structure', and the films have become known as tales of 'interlocking lives', 'converging fates', and 'the web of life'. Elsewhere l've called them network narratives." (BORDWELL, pp. 190-91)
} 
conflitos, diversas tramas acontecem paralelamente. $\mathrm{O}$ que une esses personagens é um eixo temporal (quatro horas do naufrágio do barco até o perdão final); uma unidade espacial (a ilha) e os jogos de espelhamento entre os núcleos de personagens.

São inúmeros os filmes com essa estrutura dramatúrgica que se proliferaram a partir da década de 1990. Esse modelo tornou-se tão popular que Bordwell chega a considerá-lo o princípio dominante nas estratégias usadas para se contar uma história neste período (o que o flashback teria sido para os anos 60) e lista quase duzentos títulos com dramaturgia multiplot. Também não são poucas as séries de TV que se utilizam desse modelo, sejam dramas familiares (como Six Feet Under, em que acompanhamos as diferentes trajetórias dos seis protagonistas), ou suspenses (como Lost, em que cada episódio privilegia um dos doze personagens principais).

Podemos reconhecer em Escuro alguns dos princípios apontados por David Bordwell como fundadores da narrativa em rede (mosaico social, diversos personagens com objetivos diferentes; pouca causalidade; espelhamento nos núcleos do "tema"; tensão entre realismo e artifício). De saída, podemos encontrar uma unidade espacial (Clube Atlético Arujá) e temporal (um domingo de fevereiro de 1959, das 10:32 até o final da tarde, em que começa a chover) que agrupa todos os personagens. Mais do que um pano de fundo para a ação, este contexto ganha o primeiro plano e evidencia, como nos filmes multitrama, o mosaico social em que os personagens estão inseridos.

O foco da trama não deixa de ser os conflitos e motivações dos vários protagonistas, mas compete igualmente com todo o "diagrama" em que eles se inserem, as convergências e divergências entre as relações sociais ou, como na citação de Italo Calvino feita por Bordwell, com "the design that emerges from the squiggles on the carpet." 115

No caso de Escuro, o mosaico desenhado é a sociedade e a cultura do interior paulista no início da década de 60. Nesse desenho, destacam-se o uso abusivo de cigarros, bebidas

\footnotetext{
115 "As the characters'activities diverge and converge, these crisscrossings eventually settle into a more or less cogent pattern, Calvino's 'squiggles in the carpet'. No wonder critics sometimes call these movies mosaics: when we back off from the tiny bits, we discern a larger composition". (BORDWEEL, p. 193)
} 
alcóolicas, declarado sexismo e preconceito com a deficiência como "temas"116 subjacentes da dramaturgia. Sabina Anzuategui afirma, em sua tese de mestrado "Dramaturgia Interativa e Novas Tecnologias", que:

\begin{abstract}
"Além dos temas maiores, há também nos filmes multiplot motivs visuais e sonoros que reforçam a relação entre as várias tramas. Short Cuts usa esses recursos com primor, fazendo belos cortes como o copo de leite no criado-mudo do garoto que acabou de ser atropelado, e um copo de leite na tv de Earl, num comercial que diz "acidentes acontecem". Numa conversa de telefone entre as duas irmãs Sherri e Marian, as duas estão comendo a mesma pasta de amendoim. Num corte entre Betty e Claire, duas personagens que não se relacionam no enredo, a relação é criada na seqüência de imagens em que as duas atravessam portas em suas casas. Ou ainda o corte do corpo da moça afogado no rio, para o rosto de Arlene atrás do aquário." [ANZUATEGUI]
\end{abstract}

Em Escuro, os "motivs visuais" são evidências do comportamento de um meio social e evidenciam questões sociais propostas pela dramaturgia. Pequenos gestos (como uma coceira na perna, ou o acender de um cigarro) poderiam ser detalhes de ações físicas dos atores, mas ganham o status de elemento essencial à dramaturgia, já que esta está interessada em colocar em primeiro plano não só os dramas pessoais das personagens, mas também os hábitos e as normas culturais que constituem o diagrama daquela sociedade. Fazem parte também do mosaico social desenhado: o livre adultério de homens casados, a repressão a certos modos-devida alternativos, a repercussão de casos isolados de divórcio, o lugar da mulher em uma sociedade pré-feminista, o tratamento oferecido à deficiência física.

Se em uma dramaturgia com um único (ou um par) protagonista, esforça-se para gerar desequilíbrios e reestabelecer estabilidades, o roteiro de um filme multitrama já tem a seu favor a variação de personagens e motivações. As mudanças em cada personagem, logo, são em menor número: isto é, há muita variação de personagens, mas cada personagem tem poucos conflitos.

\footnotetext{
${ }^{116}$ Vale dizer, aqui, que entendemos "tema" como uma idéia que mantém o interesse do "leitor" na trama, como afirma B. Tomachevski.
} 
Os dez protagonistas de Escuro apresentam objetivos divergentes (que por vezes colidem), o que permite ao ritmo das cenas ser bastante lento, pautado nos detalhes, sem comprometer o envolvimento do espectador com a fábula. De fato, não há grandes acontecimentos catalisadores, como acidentes de carro ou catástrofes naturais (o que parece ser praxe em roteiros de múltiplos protagonistas). As linhas de ação desenrolam-se de forma bastante lenta, costurada em diálogos naturalistas que pouco revelam sobre os estados interiores das personagens - criando uma evidente tensão entre os "motivos dinâmicos" e o discurso das personagens. Mesmo quando acontecimentos extraordinários ocupam a cena (como o acidente final), a estrutura dramatúrgica os dissolve em diálogos breves, imagens rápidas e pouco - ou nenhum - apelo dramático. Ao substituir as situações-limites por lacônicos diálogos e ação restrita ao contexto social, esta dramaturgia encoraja - e até mesmo exige - um novo modo de engajamento da audiência.

Isso não quer dizer o espetáculo retira o suspense e a expectativa, importantes para o envolvimento com a fábula. A cena inicial proposta no agenciamento que foi apresentado como espetáculo evidenciava um acidente que aconteceu na piscina do Clube Atlético, mas não revelava quem sofreu tal acidente ou qualquer causa dele. Dissolvidas no diálogo naturalista, as grandes tragédias precisam ser refeitas em nossa imaginação. A narrativa nos convida a agir, buscando pistas nos diálogos que nos conduzam às motivações interiores das personagens, confrontando nossas expectativas por eventos catalisadores, explorando as lacunas deixadas na trama. E, principalmente, nos convida a tornar evidentes os artifícios e estratégias criativas da peça.

\section{O Caleidoscópio}

Um modo de compreender a estrutura narrativa proposta em Escuro é através da metáfora do caleidoscópio. 
Como Janet H. Murray já ressaltou, os meios de comunicação do século XX são, no que se refere à estrutura, mais mosaicos que lineares, se comparados (por exemplo) com um livro impresso.

\begin{abstract}
"Os jornais são feitos de muitas histórias, exigindo nossa atenção numa única página; os filmes são mosaicos de tomadas individuais; e a televisão é ainda mais mosaica na era do controle remoto (...). Esses formatos de mosaico informativo criaram padrões de pensamento também em mosaico que hoje nos parecem óbvios. Já nos acostumamos a ver a primeira página de um jornal sem que nos sintamos subjugados, pois aprendemos a absorver múltiplas variedades de informação com um rápido olhar. De forma similar, os anos que passamos assistindo a filmes permitem-nos montar automaticamente suas imagens descontínuas em padrões de continuidade mais amplos. Temos a capacidade de fazer isso porque sabemos ler as convenções desses meios. Somos orientados pelo tamanho das manchetes e pela disposição dos artigos na página para nos localizar entre os diferentes tipos de histórias nos jornais. Sabemos construir um espaço contínuo num filme associando tomadas externas e internas, e sabemos que uma mudança na iluminação ou no foco assinalam uma cena em retrospectiva ou uma memória subjetiva. A organização em mosaico é valiosa porque nos proporciona uma visão geral da primeira página e a cadência narrativa mais rápida do filme. Também saboreamos as justaposições que essas formas mosaicas tornam possiveis: as tomadas do chefão da máfia num batismo intercaladas por tomadas dos assassinatos por ele ordenados; a coluna liberal lado a lado com a coluna conservadora na página dois do jornal; as animadas séries cômicas dos anos 50 a apenas um clique de controle remoto dos sensacionalistas programas de auditório. $O$ computador presenteia-nos com o mosaico espacial das páginas dos jornais, o mosaico temporal dos filmes e o mosaico participativo do controle remoto da televisão."117
\end{abstract}

Murray ainda afirma que, além de nos fornecer uma multiplicidade de meios mosaicos, o ambiente digital ainda nos oferece novas formas de dominar essas fragmentação, através de "mecanismos de busca" e modos de "etiquetar" a fragmentação e assim, reconstruir a trajetória particular que percorremos numa rede de caminhos virtuais.

\footnotetext{
"Ele (o meio digital) nos proporciona um caleidoscópio

multidimensional, com o qual podemos reagrupar os fragmentos
}

${ }^{117}$ MURRAY, 2003: 154 
tantas vezes quantas quisermos, e permite que transitemos entre padrões alternados de organização em mosaicos." ${ }^{118}$

Essa estrutura caleidoscópica traz diversas possibilidades narrativas. Uma delas é a capacidade de apresentar ações simultâneas de múltiplas formas. Em um romance, ações simultâneas são apresentadas sequencialmente. Mesmo quando há eventos simultâneos, normalmente eles são descritos através de sobreposições - e não de segmentos de tempos completamente paralelos; a ação da história continua movendo-se para frente enquanto nosso ponto de vista se altera. Já num filme multitrama (como descrito anteriormente), podemos saltar entre várias linhas narrativas, e até mesmo trafegar temporalmente para trás e para frente entre os acontecimentos. Em um hipertexto, porém, podemos dispor todas as ações simultâneas em uma grade e, então, permitir que o interator navegue entre elas. Podemos unir a expansibilidade do romance com os cortes rápidos e intercalados dos filmes. Para, em dramaturgia, conseguirmos essa união, sem que o interator seja subjugado pela quantidade informações, é preciso um conjunto coerente de convenções que sinalize aos interatores quando eles podem ir de uma ação simultânea para outra e para ajudá-los a saber onde e quando as várias ações estão ocorrendo. Ainda citando Murray:

"Podemos começar desenvolvendo as convenções teatrais de entrada
e saída de palco, mas, numa história digital, o palco da narrativa pode
ter múltiplos cenários, isto é, vários ambientes separados que
participam do âmbito da ação dramática. Sempre que os personagem
se deslocarem por esses cenários, o leitor/interator deve ser capaz de
acompanhá-los, exatamente como uma câmera pode seguir um ator
de um aposento para outro. O enredo de uma narrativa de múltiplos
cenários deve ser construído de forma a desperatar a curiosidade dos
leitores, seduzindo-os de um cenário para o seguinte."119

Em Escuro, a simultaneidade da ação acontece em um mesmo espaço abstrato e há marcadores textuais que esclarecem as convenções e os deslocamentos temporais ao público, em uma estrutura que privilegia os pontos de conexão entre as narrativas e a horizontalidade o diagrama formado pelos encontros e desencontros das personagens.

\footnotetext{
118 MURRAY, 2006: 155

${ }^{119}$ MURRAY, 2006:156
} 
Murray usa o próprio teatro para exemplificar tal estrutura dramática, ao descrever a trilogia "The Norman Conquests", de Alan Ayckbourn, encenada em Londres e Nova York, em três noites consecutivas.

\begin{abstract}
"A trilogia gira em torno de três casais: Annie, uma garota solteira que cuida de sua mãe, acamada e mal-humorada, e seu pretendente demasiado tímido, Tom, um veterinário; Ruth, a metódica irmã de Annie, e seu marido mulherengo, Norman; e Reg, irmão de Annie e Ruth, e sua ultracontroladora esposa, Sarah. A ação cômica desenvolve-se na casa de Annie e envolve os flertes de Norman tanto com Annie quanto com Sarah, enquanto ele tenta apaziguar Ruth; a lerdeza com que Tom tenta conquistar Annie; e as discussões de todos entre si. Essa criativa comédia romântica torna-se mais instigante por sua singular organização espacial: todas as três peças cobrem o mesmo período de tempo e envolvem os mesmos personagens, mas cada uma retrata os acontecimentos em diferentes partes da casa-a sala de jantar, a sala de estar, o jardim. Uma saída de palco numa peça é uma entrada numa das outras. Os atos das peças são cuidadosamente rotulados com data e hora, e a ação é primorosamente coordenada para que as três possam ser reunidas (na mente do espectador) como uma única apresentação dramática em múltiplos palcos. ${ }^{\prime 120}$
\end{abstract}

Esta é uma estrutura dramática que exige um espectador que navegue, mas também sugere a dificuldade de contar uma história com ações simultâneas. Essas histórias entrelaçadas reforçam o caráter caleidoscópico de organização de nossas mentes e passam a exigir um outro formato de representação. Um texto linear parece não mais comportar narrativas tão complexas e destratificadas. O tecido dramático proposto é, então, melhor representado, como um mapa.

\title{
O Mapa
}

Do que foi dito, concluímos que a dramaturgia de Escuro não é um texto, mas um hipertexto que só pode ser representado como um mapa. Apresento, a seguir, o mapa dramatúrgico que funciona como pólo originador de possíveis espetáculos teatrais.

\footnotetext{
${ }^{120}$ MURRAY, 2006: 156
} 

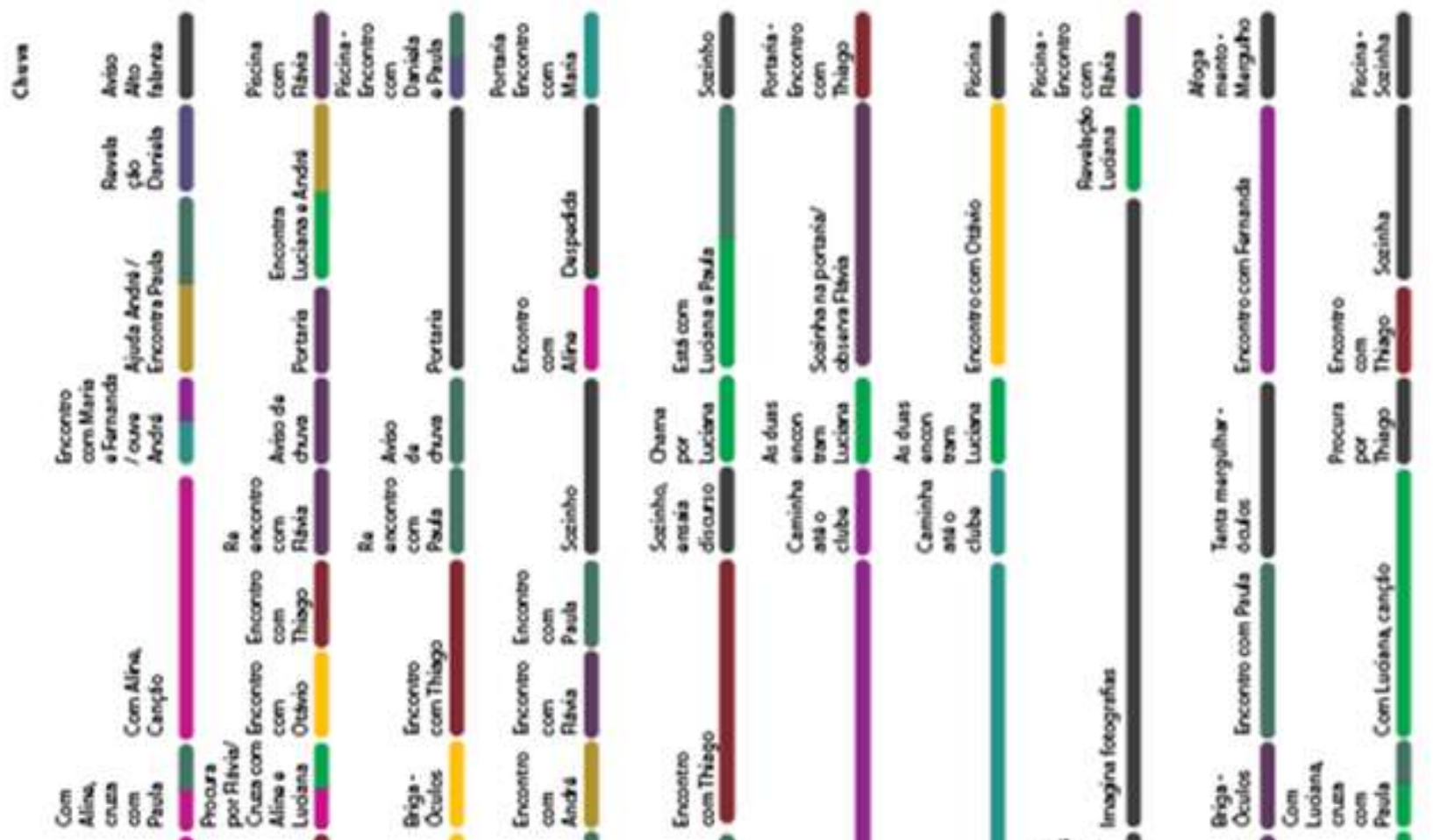

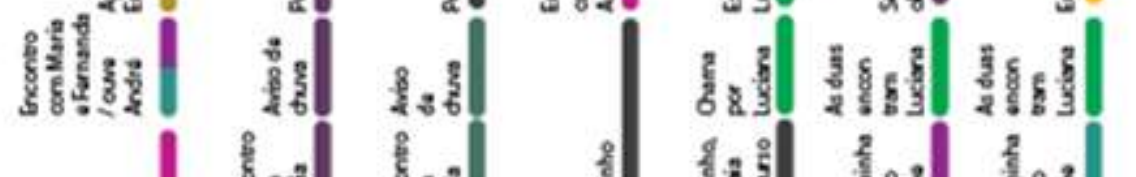

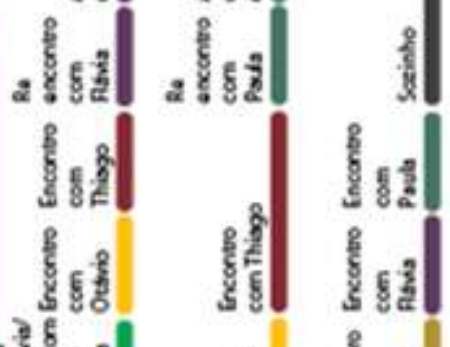

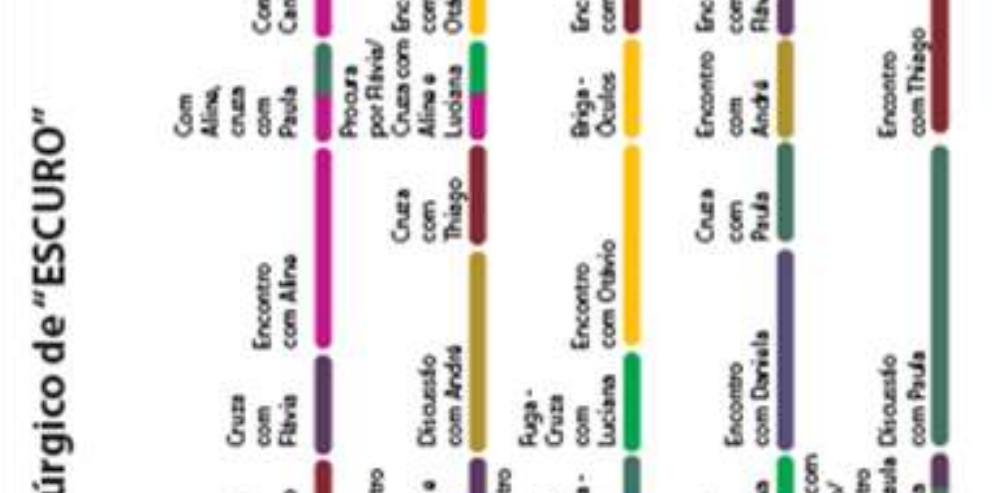

maํ.

i

It

init

ป⿱⺈
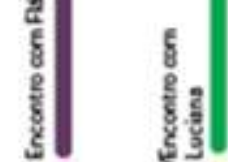

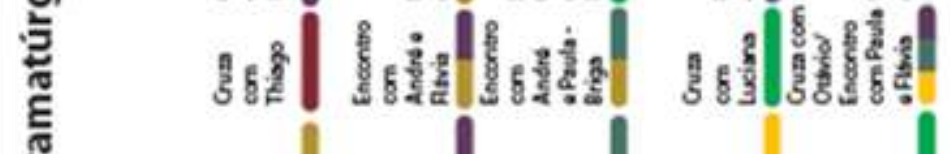

,

竞
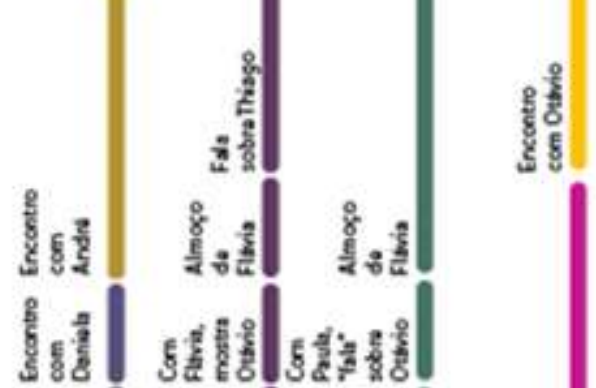

[!!

in!

in

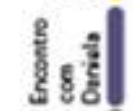

il

II

| $t h$

IIII ร!I

埩

III

!n

II

II

I?

期

all !ll

II $\begin{array}{cc}\ln & \text { III } \\ 41 & 4\end{array}$

inil

lil

If

1 hl

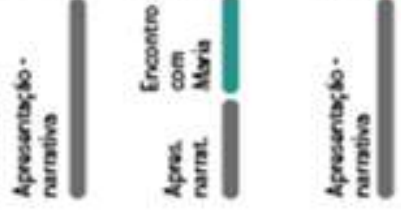

$\mid$ | 
Há, como vimos, uma unidade espacial e temporal que reúne os personagens. O desenho do mapa segue essa cronologia (da esquerda para a direita), que vai desde a manhã de um domingo até o fim da tarde, com o início da chuva e um acidente na piscina. A chuva (e as mudanças climáticas que a anunciam) é o acontecimento externo que garante uma coesão temporal entre as personagens, uma convenção que sempre aparece como uma espécie de marcador temporal ao público.

Cada uma das linhas do mapa representa a trajetória de uma personagem. Numa leitura horizontal, seguimos o caminho individual - seus encontros, descobertas etc - naquele intervalo de tempo. Numa leitura vertical, entendemos o que está acontecendo simultaneamente aquele determinado encontro. Cada personagem é também identificado com uma cor específica. Esta cor aparece também nos encontros. Assim, sabemos que um determinado encontro de cor $\mathrm{X}$ corresponderá ao mesmo momento na trajetória do personagem de cor $\mathrm{X}$. Isso nos permite navegar o mapa dramatúrgico de acordo com os pontos de vista de cada personagem e identificar rapidamente os cruzamentos.

Cada encontro, ou cena, é descrito por um título simples que nos guiará até uma "enciclópedia" dessas cenas, sem ordem pré-definida. A reorganização e o agenciamento de destas cenas é que determinará o texto de um possível espetáculo.

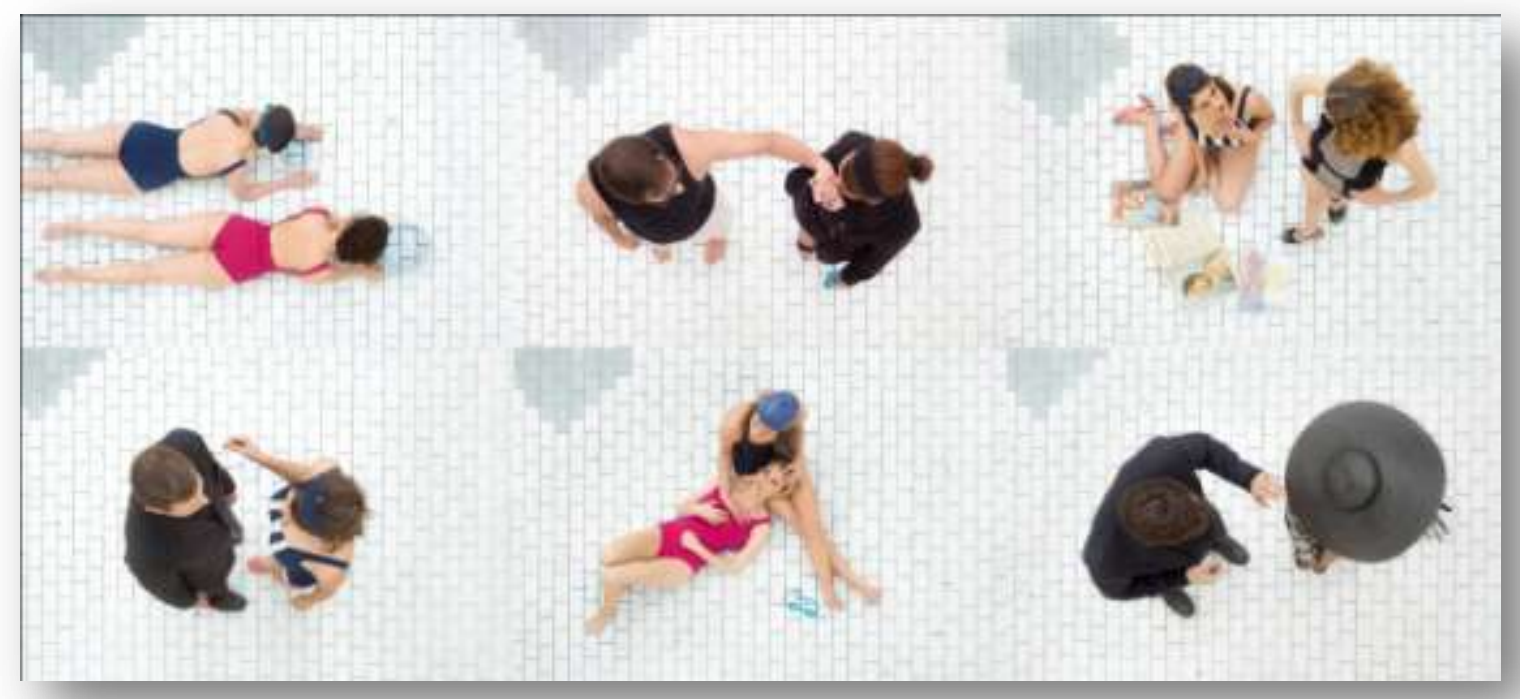


Apresentado o mapa dramatúrgico que foi criado, veremos de que modo os conceitos de hipertextualidade, imersão e agência aparecem em Escuro.

\section{Hipertextualidade}

Neste ponto do trabalho, fica claro o que temos chamados de caráter hipertextual desta dramaturgia. Temos um mapa de cenas que pode ser lido de diversas formas. Isto quer dizer que temos uma rede de trajetórias formando um emaranhado fragmentado, múltiplo e simultâneo. Este diagrama apresenta um universo fictício específico em que privilegiam-se as conexões entre as linhas/trajetórias mais do que a próprio "arco dramático" de cada personagem.

Podemos navegar por este hipertexto de diversas formas. Poderíamos, por exemplo, acompanhar linearmente a personagem Luciana (verde-claro) em seu encontro com Otávio (Menino) na portaria do clube, segui-la até o encontro com Paula para em seguida vê-la interagir com Daniela e com André e assim por diante até, finalmente, sabermos onde ela estava no momento em que começa a chover (momento que coincide com o clímax dramático que é o acidente na piscina).

Outra possibilidade seria acompanharmos Luciana até seu encontro com Otávio (amarelo) e, a partir daí, seguirmos Otávio até seu encontro com Thiago (vermelho). Trocaríamos então, mais uma vez, de protagonista e passaríamos a acompanhar Thiago até seu encontro com Daniela (roxo). Acompanharíamos Daniela a partir daí e assim sucessivamente, sempre trocando o ponto de vista e o protagonista da dramaturgia.

Poderíamos ainda inverter a cronologia e começarmos do acidente de Otávio na piscina. A partir daí, voltaríamos até o momento anterior, em que ele se encontra com Fernanda (magenta), e então saberíamos como Fernanda entra no clube com a ajuda de Maria Amélia (azul) e Luciana. E voltaríamos do encontro de Luciana com Aline (rosa) e assim o faríamos até o momento inicial, em que Otávio entra no clube. 
Um mapa com tanta possibilidade dramática é mais imersivo do que um texto tradicional, em que acompanhamos o desenvolvimento de um ou dois protagonistas. No entanto, é preciso desenvolver convenções bem definidas para navegarmos através dele. Devemos permitir movimentações tanto para trás quanto para frente no tempo, além de movimentações diferentes através de um mesmo instante de tempo. Para isso, é preciso que cada célula (cena) tenha um valor autônomo e seja capaz de comportar alguns marcadores que permitirão ao leitor localizar temporal e espacialmente aquela situação dentro do emaranhado de situações simultâneas.

Nos momentos de conexão deste mapa, o leitor deve poder ir de uma narrativa para outra sem perda(assim como um filme pode passar a seguir um personagem e cortar a história de outro). De acordo com os caminhos escolhidos para se percorrer este mapa, qualquer evento compartilhado pode ter diferentes significados, dependendo do fato de esse mesmo acontecimento ser abordado no contexto da trajetória de um persongem ou de outro. Por exemplo, se vista dentro da trajetória de Paula (verde-escuro), a cena em que ela encontra Luciana e André (ocre) juntos temos o ponto de vista de uma esposa traída. Se contextualizada na trajetória de André, vemos tratar-se de uma crise de afasia. Já na trajetória de Luciana, o que temos é o ponto de vista da amante. $\mathrm{O}$ ato de navegar de um ponto de vista a outro reforça a separação entre o mundo interno e o externo destas três personagens e reencena o gesto de conexão entre elas. Ao alternarmos nosso ponto de vista diante de um único momento de síntese dramática, apreendemos tanto a realidade compartilhada quanto às experiências individuais que a compõem.

Nas palavras de Murray:

"O poder caleidoscópico (...) permite-nos contar histórias que refletem com maior autenticidade nossa sensibilidade da virada do século. Não acreditamos mais numa realidade singular, numa visão única $e$ integradora do mundo, nem mesmo na confiabilidade de um só ângulo de percepção. No entanto, retemos o desejo humano fundamental de fixar a realidade sobre uma tela apenas, de expressar tudo o que vemos de modo integrado e simétrico. A solução é a tela caleidoscópica, capaz de apreender o mundo como ele se apresente 
desde diferentes perspectivas - complexo e talvez incompreensivel no

final das contas, mas ainda assim coerente."121

\section{Trajetórias e personagens}

Cada uma das dez trajetórias comporta diferentes cenas e encontros. Essas cenas é que formam o arquivo de cenas virtuais prontas a serem atualizadas por um navegante. Cada trajetória foi criada em colaboração com o ator que interpreta cada um dos papéis. Vale dizer que esta forma tão cúmplice de criação é evidenciada no fato de cada ator emprestar seu próprio nome ao personagem.

O processo de criação dos personagens aconteceu em sala de ensaio, através de exercícios e estímulos muito simples. A partir de fotografias de um clube atlético na década de 50 , foi pedido a cada ator que elaborasse uma pequena biografia ficcional de um personagem. Não era um exercício de escrita, mas de criar um universo ficcional claro sobre o qual se pudesse improvisar. Individualmente, cada ator entrava no espaço cênico, com um ritmo de respiração específico (a partir de um trabalho com níveis de tensão ${ }^{122}$ ) e apoiado por um ponto físico. Iniciava-se, então, uma espécie de "entrevista" com o ator. Não havia, neste ponto, a composição de um personagem, mas o ritmo da respiração e os pontos físicos modificavam a forma e a dramaturgia das respostas. As respostas a esta entrevista, sempre pautadas na ficção previamente elaborada pelos atores, acabaram por ser determinantes na criação das personagens.

Essas entrevistas foram refeitas diversas vezes, aprofundando e aprimorando a construção dramatúrgica individuais. Depois, as entrevistas passavam a ser em duplas ou coletivas. Isso permitiu que fosse sendo criado um contexto único aos personagens, situações compartilhadas entre eles e o estabelecimento de relações potencialmente dramáticas em duplas. A partir destes exercícios, surgiu uma série de situações cênicas individuais ou coletivas

\footnotetext{
${ }^{121}$ MURRAY, 2006: 159

${ }^{122}$ Não descreverei esse processo aqui, tendo em vista que o foco da dissertação é a criação de dramaturgia e nào o trabalho dos atores, embora uma coisa esteja intimimamente ligada a outra, no caso de Escuro.
} 
e, a medida que estas eram refeitas, definiam-se melhor os encontros e desenhava-se o mosaico de relações que iria compor o espetáculo.

A partir deste material, foi escrita uma primeira versão do texto, ainda sem trajetórias individuais. Este material foi analisado e estudado por cada ator, que separou suas cenas e desenhou uma trajetória individual. A partir daí, deu-se inicíoo a uma série de improvisações a partir das trajetórias de cada personagem/ator. O ator improvisava, em sequência, todos os encontros que aconteciam no "dia de sua personagem". Todos os atores participavam da realização da trajetória de um ator.

A partir deste exercício, em que a mesma cena era revista em contextos diferentes, extraiu-se um possível modo de transitar entre trajetórias, "girando" o espetáculo como um caleidoscópio, vendo e revendo cenas sob pontos de vistas diferentes (e por vezes contrários). Essas longas improvisações de trajetória ampliaram nossa percepção sobre a multiplicidade de leituras de um mesmo encontro e foi a chave para que, mais tarde, os diálogos pudessem ser escritos.

\section{Trajetórias de Convergência}

Entre as dez trajetórias paralelas criadas em "Escuro", duas destacam-se por servirem como elo entre todas elas. Apesar de autônomas, estas trajetórias promovem uma certa "costura" entre todas as personagens, garantindo a coesão de uma história tão múltipla. As personagens Luciana e Menino/Otávio percorrem todas as outras trajetórias e funcionam como personagens-marcadoras da narrativa. Vale a pena observarmos mais atentamente cada uma destas trajetórias. 


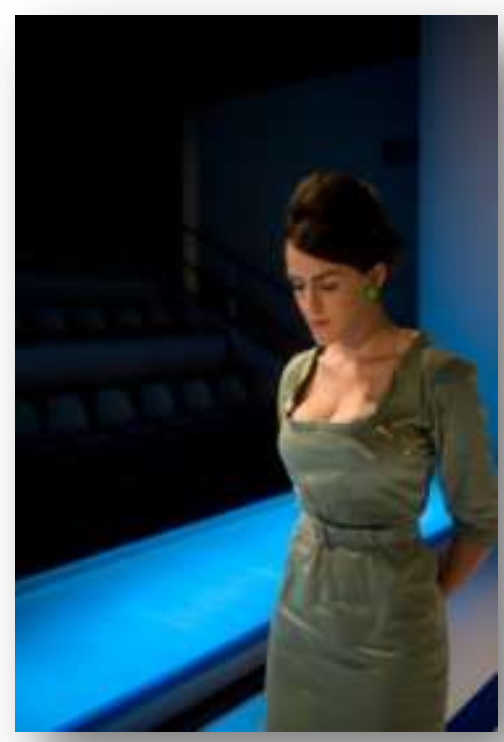

\section{"A voz de Arujá"}

Luciana trabalha no Clube Atlético Arujá. Desde o início, sabíamos que ela seria uma das personagens responsáveis pela "costura" entre as trajetórias. Sua condição de funcionária permitia um grande trânsito entre todas as outras personagens e espaços, sempre agindo como intermediária entre as relações. Também por essa condição, Luciana possui dois conflitos particulares: ela tem um caso afetivo com o dono do Clube, André, que é noivo de Paula (a quem ela gentilmente serve) e ela sonha em cantar num concurso que está sendo promovido pelo Clube, "A Voz de Arujá" (situação que dá título a sua trajetória). Luciana transita facilmente entre os diversos núcleos de personagens e une dramaturgias diferentes (é a personagem que mais percorre espaços e que de mais encontros participa).

Assim Luciana apresenta-se, em terceira pessoa, contando seu "segredo" a Otávio:

\section{LUCIANA}

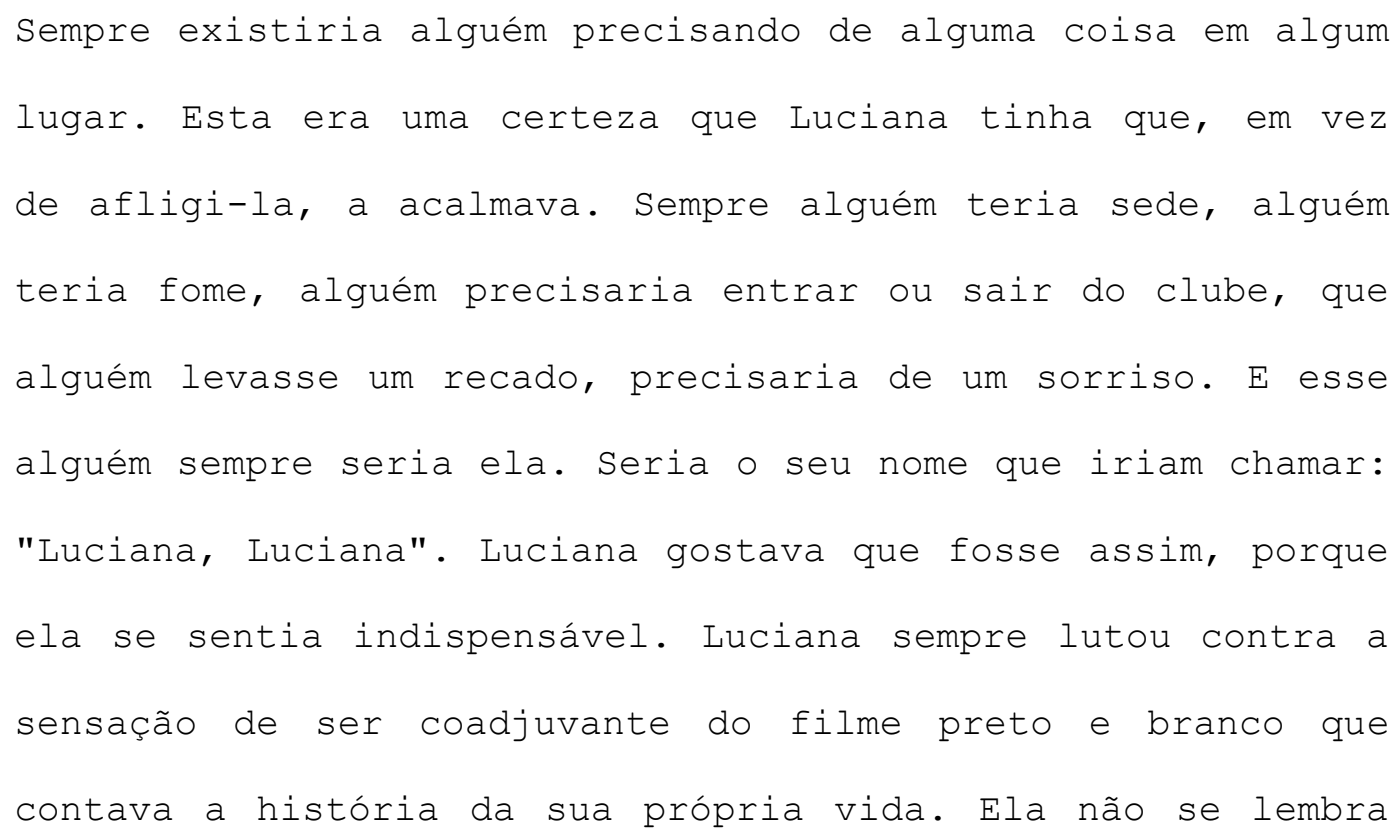




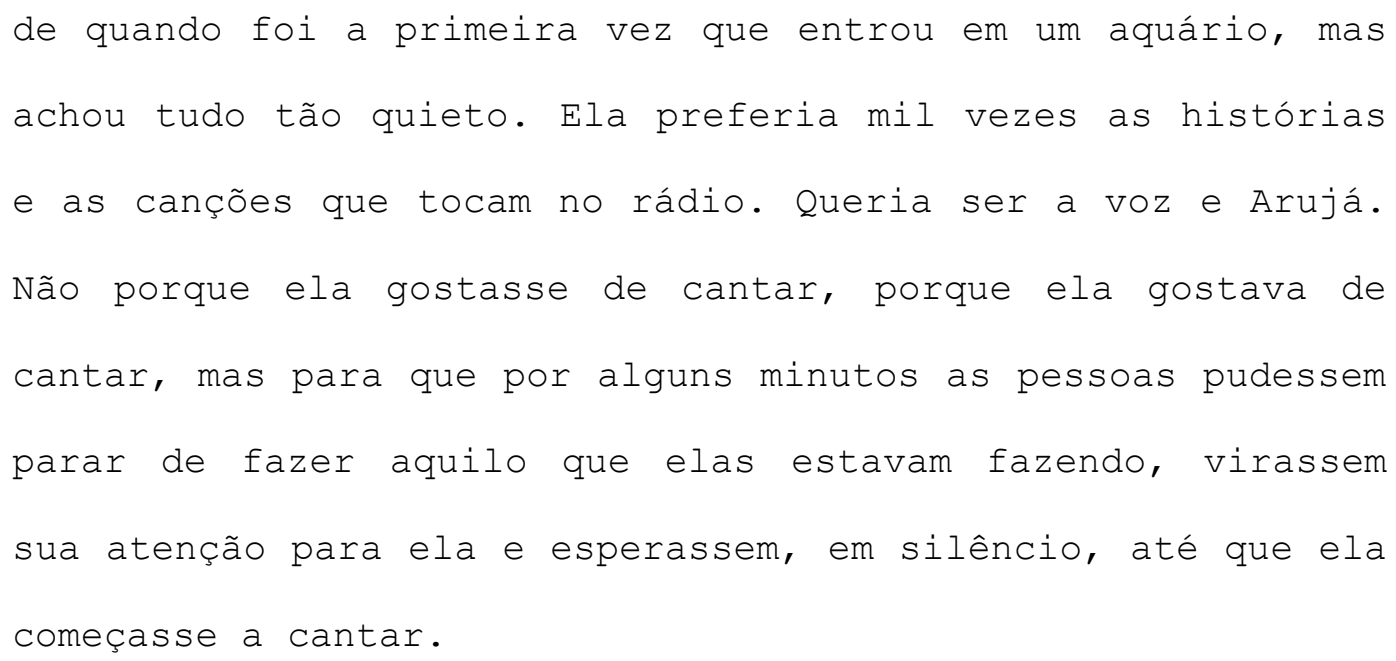

Sua trajetória envolve:

a. encontrar-se com o menino na portaria, contar a ele seu "segredo, cometer a infração de deixá-lo entrar no clube, mesmo sem carteira de sócio ou a presença do pai;

b. servir Paula e sua irmã à beira da piscina;

c. levar bilhetes de um admirador secreto que ela mesma inventou para Daniela;

d. pedir a André, com quem tem um caso, que ele a deixe participar do concurso "A Voz de Arujá" - pedido este que é recusado;

e. rejeitar Thiago que insiste que ela leia os recados que escreve em fotografias no altofalante do clube;

f. ser agredida acidentalmente por Flávia;

g. encontrar-se à beira da piscina com Aline e, junto com ela, cantar finalmente uma canção;

h. impedir que Maria Amélia entre no Clube, permitindo apenas a entrada de Fernanda; 
i. socorrer André de uma crise de afasia, sendo flagrada por Paula - que ordena que ela peça a Daniela para que avise que o torneio está cancelado;

j. revelar a Daniela que o admirador secreto é uma invenção;

k. anunciar o cancelamento do torneio no altofalante/ comunicar o acidente.

Podemos notar que Luciana cruza com todas as personagens e sempre está presente em momentos cruciais para a trajetória de cada uma delas: ela participa da desilusão de Daniela ao descobrir que não tem um admirador secreto, participa também da crise de André e decisão final de Paula; ainda está envolvida diretamente na entrada de Otávio no clube. Seu próprio arco dramático tem um clímax coincidente com a personagem Aline (momento em que as duas cantam). Transitando pelo Clube, a trajetória de Luciana desenha a paisagem espacial do espetáculo.

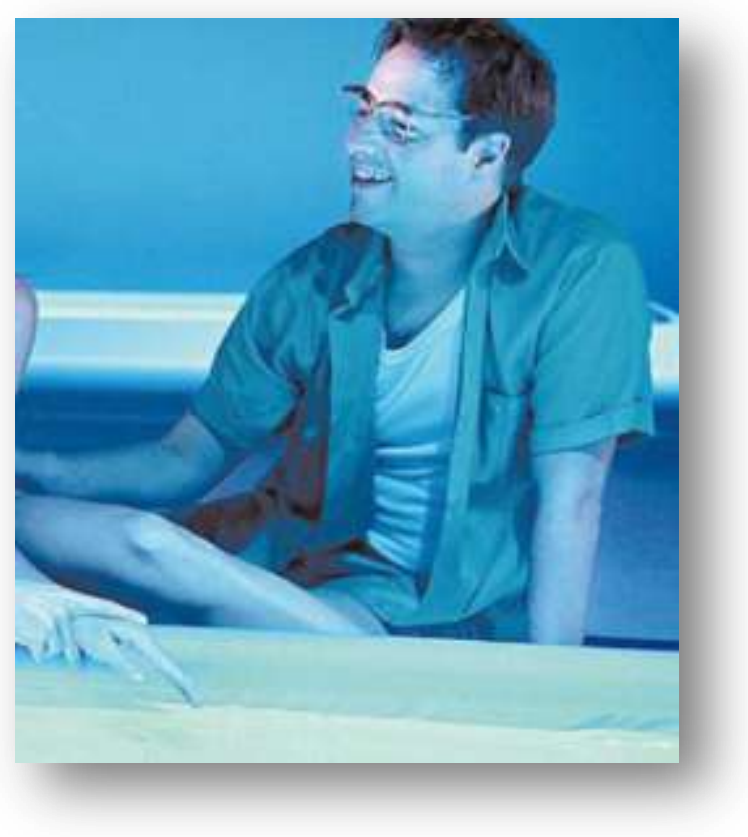

\section{"O Menino"}

Enquanto Luciana liga espacialmente as personagens, o "Menino" é quem efetivamente funciona como elemento de convergência da dramaturgia. Ele é responsável por ouvir todos "os segredos" das personagens. É a partir dele que a dramaturgia se reorganiza, já que ele faz parte do início de cada uma das trajetórias. $\mathrm{O}$ argumento de que o Menino tem a capacidade de ouvir os segredos das pessoas dá a ele livre acesso à consciência dos personagens, o que aproxima seu olhar do olhar do espectador. Somente através do menino, dos pensamentos que ele consegue ouvir, temos acesso ao universo interior das personagens. Sempre mergulhadas em conversas banais, que mascaram grandes emoções, as personagens deixam escapar um tom mais lírico na presença do Menino. 
Assim ele se descreve, em meio a um diálogo bastante cotidiano:

MARIA AMÉLIA se aproxima do ouvido do MENINO e sussurra algo que não ouvimos.

\section{MENINO}

Numa idade em que as crianças ficam

desesperadas pra falar, o menino pode passar

horas só ouvindo. Tem nove anos debaixo dos

grandes óculos, ou foi o que lhe disseram.

Funcionando como um inusitado narrador dos pensamentos das pessoas, a trajetória do Menino aparece fragmentada entre todas as outras trajetórias. Outro fator de convergência evidente é que o Menino é quem sofre o acidente na piscina, fato externo que aglutina todos os conflitos da dramaturgia. Essa força aglutinadora de trajetórias faz com que o próprio Menino apareça ao mesmo tempo tanto como protagonista do diagrama dramatúrgico (sendo a síntese e ponto de encontro de toda a peça) como coadjuvante das trajetórias. Dito de outro modo, é como se, ao olharmos a dramaturgia de cima (macrocosmo) o Menino ganhasse importância fundamental ao arco dramático da peça, mas, se olharmos a partir das trajetórias individuais (microcosmo), o Menino perde força e é apenas um interlocutor, um pretexto para que todas as outras personagens se revelem.

Por exemplo, na seguinte cena, em que o Menino encontra-se com Aline:

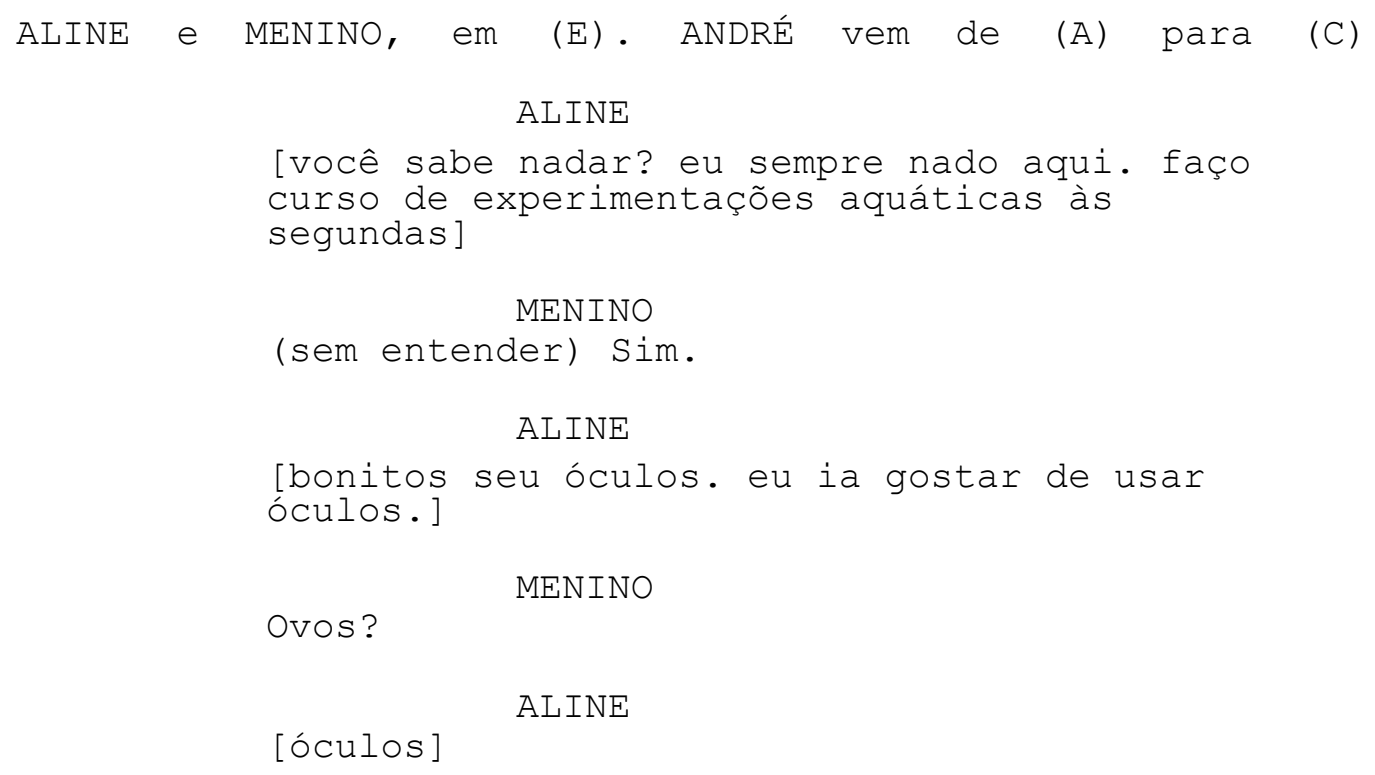




\section{MENINO}

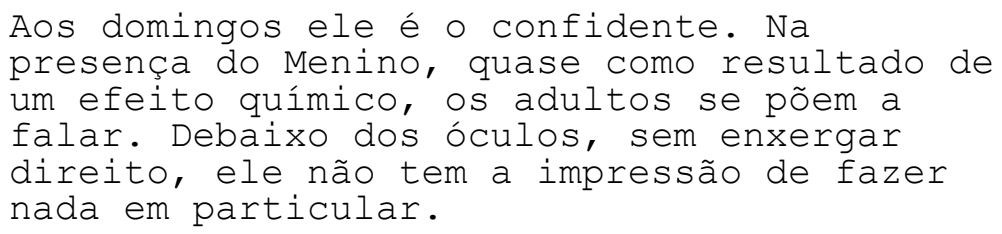

\section{ALINE}

[Está vendo aquela menina? Ela está no torneio. Ela não enxerga, não escuta. Deve ter nascido de fórceps, fórceps é um perigo. Ou então os pais dela eram primos....

\section{MENINO}

Acontece assim: está sentado no chão, preparando um mergulho, encostando o nariz nas mãos para enxergar as rugas que a água desenhou e, de repente, alguém se aproxima dele, um adulto.

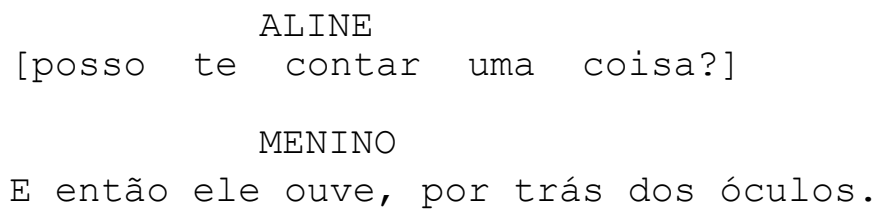

Como a personagem Aline possui afasia (suas falas estão sempre entre colchetes), mal conseguimos entendê-la. O menino funciona, então, como uma espécie de narrador que nos dá acesso aos pensamentos e desejos mais íntimos dela. Também é uma espécie de "intérprete" para o público do personagem Thiago, que não fala. O menino é quem, através de um jogo cênico, normalmente traduz o que é dito em libras (Língua Brasileira de Sinais) por ele. Sua função, nesta cena e em muitas outras, é apenas ser interlocutor e suporte para a trajetória das outras personagens. De uma forma bem diferente acontece a cena final do espetáculo, em que 
o Menino ocupa o lugar de protagonista e se atira na piscina - evento que une todas as trajetórias num mesmo ponto de intersecção.

\section{Trajetórias Conluiadas}

Outras trajetórias aparecem tão conectadas umas às outras que quase não se pode separá-las. Ou, se o tentarmos, talvez elas perdessem seu interesse enquanto unidades dramáticas. Isso acontece porque, quando separadas, não há uma mudança de pontos de vista. As duplas de personagens Maria Amélia/Fernanda e Paula/Flávia aparecem quase sempre unidas e apresentam uma única perspectiva. Devemos considerar que essas trajetórias, em determinado momento, separam-se (Fernanda entra sozinha no clube, Flávia perde-se de Paula após uma briga com André). Entretanto, essa separação não apresenta novas perspectivas. Ao contrário, reforça a cumplicidade e conexão das duas trajetórias, como vemos a seguir.

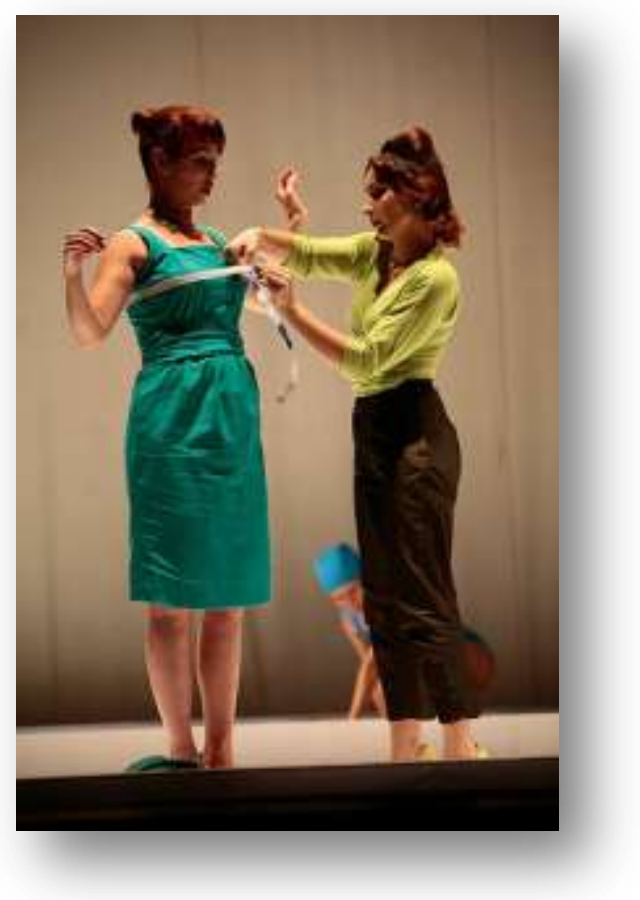

“A equipe de Natação"

Pela simples observação do mapa dramatúrgico, podemos notar como as trajetórias de Maria Amélia (azul) e Fernanda (magenta) estão conectadas - quase não há outros cruzamentos entre elas e outras personagens. Isso acontece, em primeiro lugar, porque essas são as duas únicas personagens que não estão, em tempo integral, no Clube Atlético Arujá (unidade espacial). Embora o assunto de suas conversas e toda a ação faça referência ao Clube, elas representam o ponto de vista externo a ele. Em segundo lugar, as duas personagens são as figuras que contextualizam historicamente a ação dramática, isto é, são elas quem diretamente desenham o mosaico social que inclui todas as outras personagens. Como vemos em: 


\section{FERNANDA}

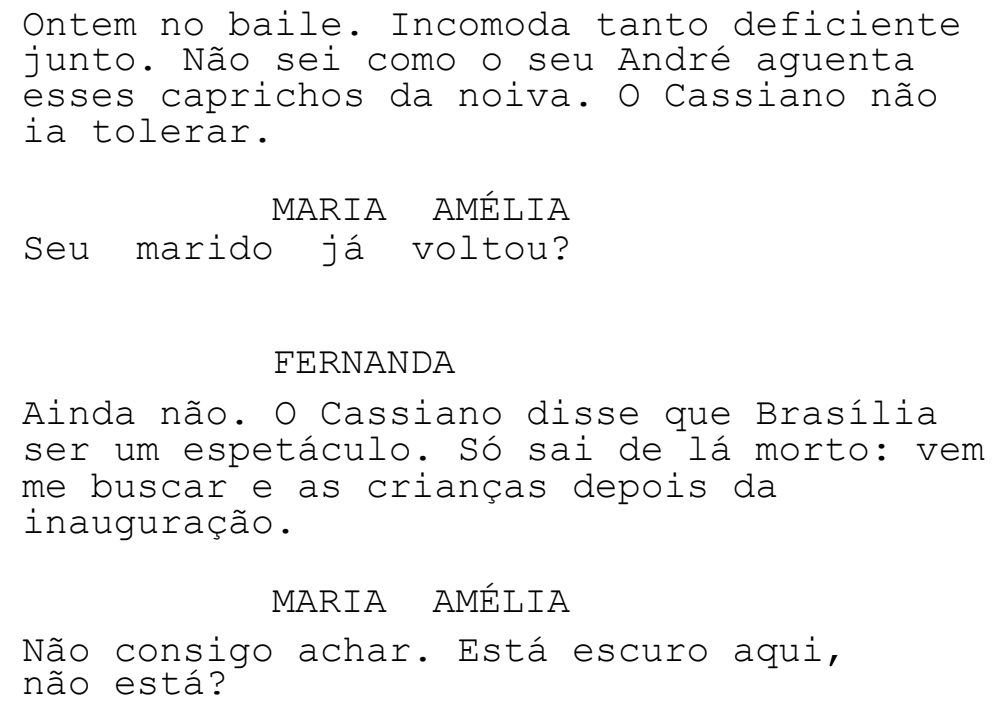

A ligação delas com as outras trajetórias acontece por paralelismos e simultaneidades do discurso com a ação de outras trajetórias (e não por encontros de personagens). Por exemplo, enquanto as duas falam de Paula e Flávia, podemos acompanhar pelo mapa que, neste mesmo momento, a fala das duas está sendo concretizada nas trajetórias de Paula (verde-escuro) e Flávia (roxo). Ou ainda no momento em que falam do retratista Thiago (vermelho), simultaneamente Thiago está mostrando suas fotos ao menino.

Uma outra particularidade desta trajetória "em dupla" é que as duas são as únicas que, juntas, não tem grande contato com a deficiência (um dos temas centralizadores do espetáculo). Se por um lado isso justifica sua ausência da rede de conexões e as determina como olhares externos, por outro, o excesso de falas esvaziadas e prolixas em suas trajetórias aponta uma espécie de estranhamento de suas ações cotidianas. Quando comparados (por simultaneidades ou sobreposições) à eloquência e falas curtas das outras trajetórias, os longos e fúteis diálogos evidenciam a insuficiência da linguagem no contexto social e redimensionam o silêncio das outras cenas paralelas. Só quando separadas, as personagens Fernanda e Maria Amélia trocam uma estrutura dialógica cheia de clichês e convenções sociais por falas mais simples e mais próximas ao tom adotado em todas as outras trajetórias. 
Ao chegarem ao clube, as duas personagens tomam direções diferentes, já transformadas pelo encontro, e só então passam a interferir efetivamente nas demais trajetórias: Maria Amélia permanece na portaria do clube e acaba por encontrar-se com Thiago (o que, ao invés de finalizar uma trajetória linear, abre uma novo caminho dramatúrgico que não irá se concretizar - é como se esse encontro reafirmasse que nenhuma trajetória se encerra com a peça); já Fernanda pede ajuda ao menino e é quem de mais perto presencia o acidente à beira da piscina.

O "isolamento" das duas personagens também contribui para que o caminho dramático desenhado por elas seja o mais próximo de uma estrutura dramatúrgica convencial: com conflitos de vontades, diálogos como trocas intersubjetivas, síntese e transformação das personagens através da fala. A presença desses elementos como uma trajetória isolada, poderíamos dizer, reforça a teatralidade do contexto social e fornece às outras trajetórias uma maior liberdade ao tratar o tempo e o conflito dramático.

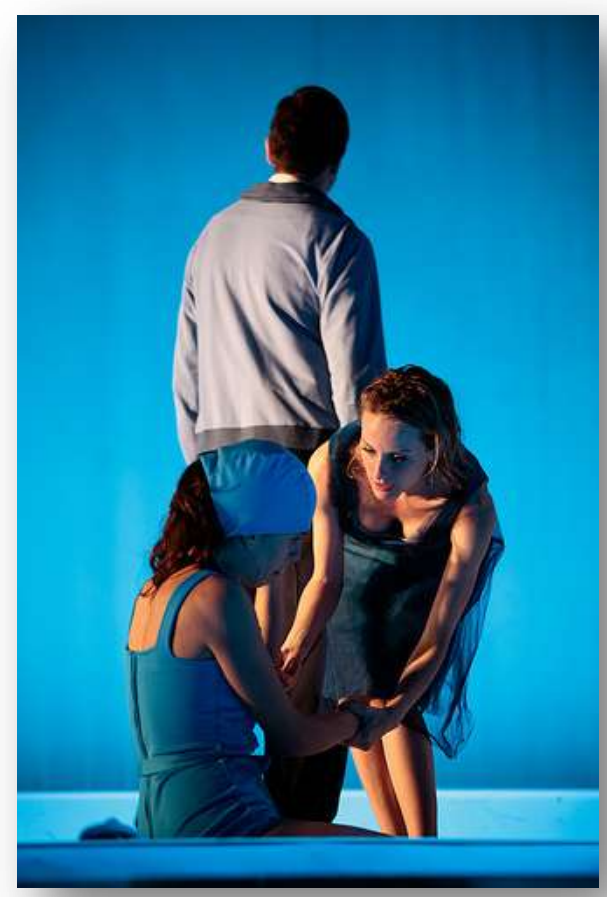

\section{“Dentro do Aquário/Fora do Aquário"}

Outras duas trajetórias que aparecem da mesma forma unidas são as das personagens Paula (verde-escuro) e Flávia (roxo). As duas irmãs permanecem juntas grande parte do tempo, à beira da piscina, treinando para o torneio. Os cruzamentos com outras personagens (ao contrário do que acontece na trajetória de Luciana) não acontecem por um impulso ativo. À beira da piscina, elas são cercadas e "visitadas" pela presença de outras trajetórias. É como se elas fossem um lugar de passagem das outras linhas. 
É justamente neste lugar de passagem que o eixo temático (a deficiência) aparece de forma mais explícita. Como duas forças opostas que não podem ser separadas, as duas irmãs ocupam os extremos de um rol de personagens marcados por diferentes graus de inadequação. De um lado, temos Paula - exemplo de comportamento adequado, de beleza física, status social (o que é revelado pelos comentários de personagens como Luciana, Maria Amélia e Fernanda), porém se sentindo completamente deslocada e infeliz com este papel; de outro, temos Flávia - cega e surda, cuja única possibilidade de comunicação é com a irmã, sendo rejeitada e reprimida por sua extrema inadequação. Trabalha-se com a metáfora de que uma está dentro e a outra, fora, do aquário.

É importante dizer também que, na trajetória de Flávia, é Paula quem assume o papel de mediadora entre ela e o público. Através de uma comunicação muito particular entre elas, podemos conhecer e entender o tipo de relação e desejos que as envolvem.

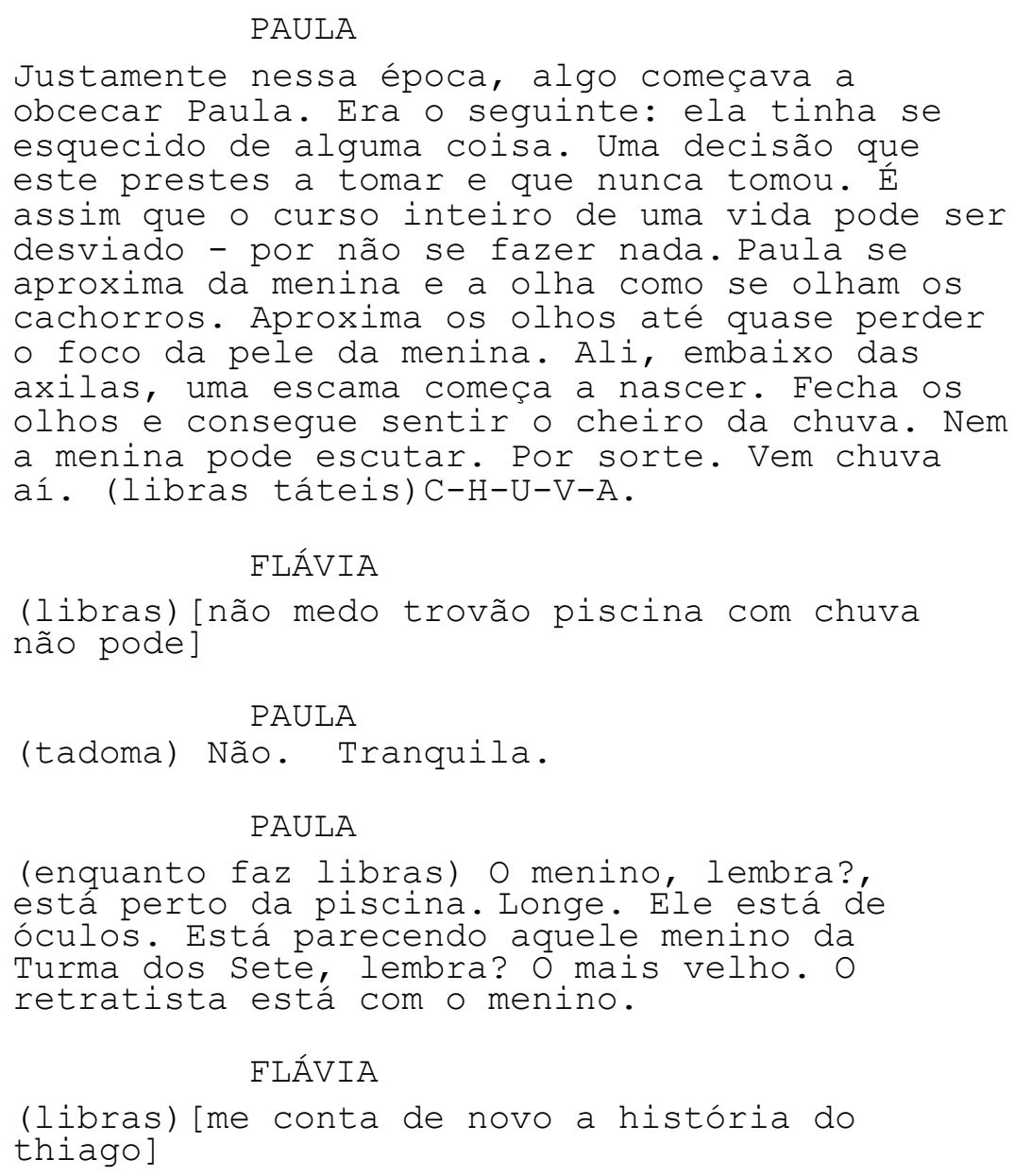




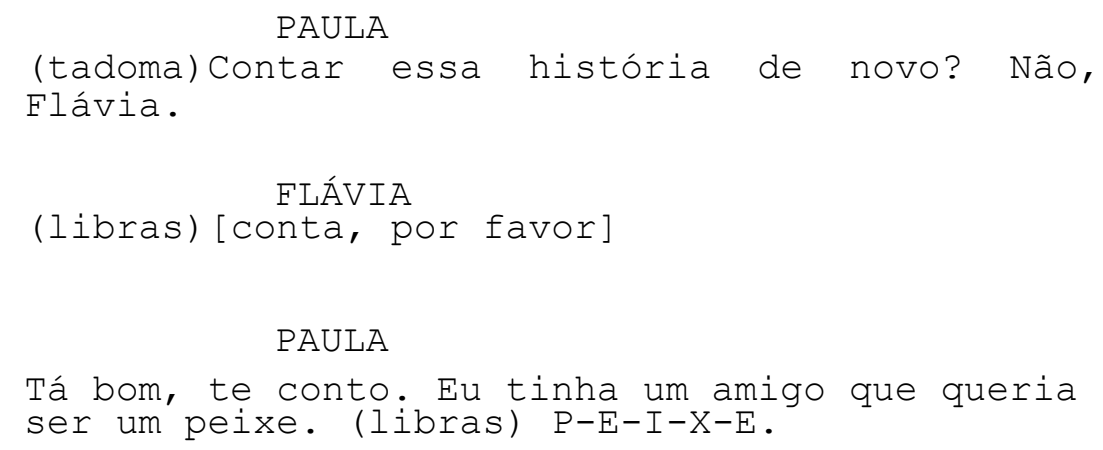

É interessante notar que a comunicação entre elas (que acontece em libras e no sistema tadoma) não é inteiramente traduzida para a plateia. Cria-se, assim, um hiato de comunicação também entre a ação dramática e o público. A cena é cheia de silêncios e momentos cifrados (o que é um contraponto direto com o excesso de diálogos da trajetória da dupla Maria Amélia/Fernanda).

As duas trajetórias, em determinado momento, também se separam. Isso, porém, só reforça como as duas são indissociáveis, já que o conflito dramático criado é justamente a tentativa de reencontro entre as duas. Flávia fica perdida no clube e passa a encontrar-se acidentalmente com outras trajetórias. Desses encontros, o mais decisivo é com o Menino, já que como resultado os óculos dele são atirados no fundo da piscina. Se acompanharmos a trajetória do Menino (amarelo), veremos que este é o ponto decisivo, a falha que irá levá-lo até o acidente final.

Já Paula inicia uma jornada pelo clube em busca da irmã. Se antes ela era uma personagem passiva, agora passa a percorrer os espaços à procura da irmã. Podemos finalmente conhecer suas motivações, sua relação conflituosa com Thiago e seu desejo de abandonar a irmã. Todos os encontros que se seguem desde a separação de Flávia poderiam conduzir Paula a uma transformação (o reencontro com Thiago, o flagrante do adultério, o desabafo com o menino). Isso, entretanto, não acontece, já que - uma vez reencontrada a irmã - ela volta à sua condição passiva. 


\section{Trajetórias de Suporte}

Há ainda personagens cujas trajetórias servem como suporte à dramaturgia, seja na forma de marcadores temporais ou espaciais ou como figuras imóveis que criam contrapontos aos desejos e caminhos de outras trajetórias.

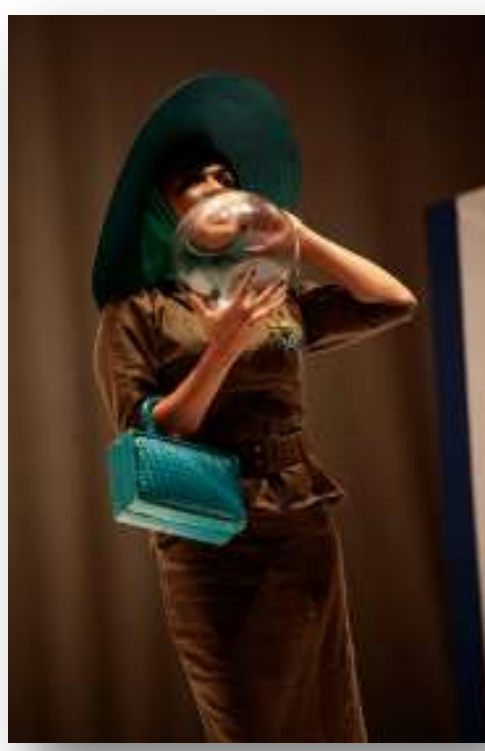

\section{"Nuvens de Açúcar"}

Daniela é quem dá os avisos no altofalante do Clube. Junto a Luciana, ela faz parte da classe de funcionários do Clube. Porém, enquanto Luciana percorre espacialmente o clube, Daniela permanece estática, em um único espaço. Isso associado ao alcance de suas falas pelo altofalante a todos os outros espaços do clube faz com que sua trajetória seja claramente um marcador temporal da dramaturgia.

A interferência do altofalante em outras trajetórias ou repetição de frases como esta -

\section{DANIELA}

Bom dia, sócios e frequentadores do Clube Atlético Arujá. Hoje, 18 de fevereiro de 1959

- data histórica para nossa querida comarca, temos o prazer de, como parte das comemorações por nossa emancipação política, realizar o Torneio Amador de Natação para Cegos e Surdos. Agora, fiquem com mais uma deslumbrante canção na voz de Dalva de Oliveira. São 10:32 da manhã .

- ou o poema que ela recita incansavelmente - servem como uma referência temporal explícita que guia o entendimento do público pela simultaneidade e que permitirá que a dramaturgia avance ou retroceda livremente. Sempre que se ouve a voz de Daniela no altofalante, somos informados em que período daquele dia estamos e podemos, assim, 
reconstruir (em nossa mente) todas as outras cenas que estão acontecendo simultaneamente àquele momento.

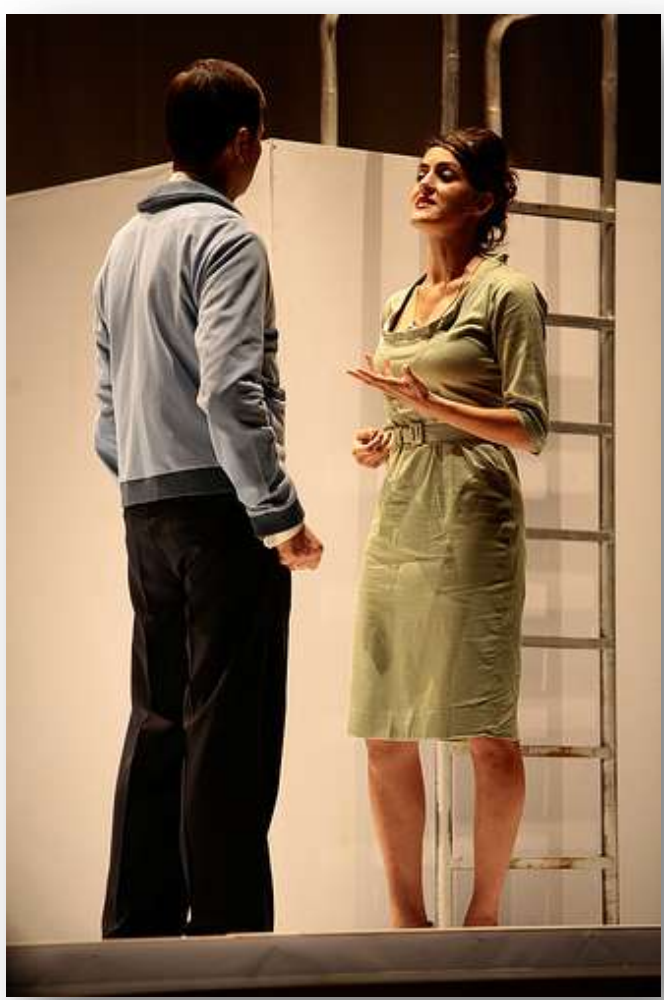

\section{“O Dono dos Pássaros”}

André é o dono do clube. Sua principal ação, durante toda a sua trajetória é ensaiar um discurso para o torneio que acontecerá no final da tarde. Sua imobilidade espacial e sua pouca ação garantem o seu lugar como vértice que suporta outras trajetórias. É ele o responsável pela separação das trajetórias de Paula e Flávia, é também ele o ponto que une as trajetórias de Luciana e Paula (noiva e amante) e a causa que impede o encontro das trajetórias de Paula e Thiago.

A principal função da trajetória de André, então, é ser um vértice (ora de encontro, ora de desencontro) entre as personagens. Por exemplo,

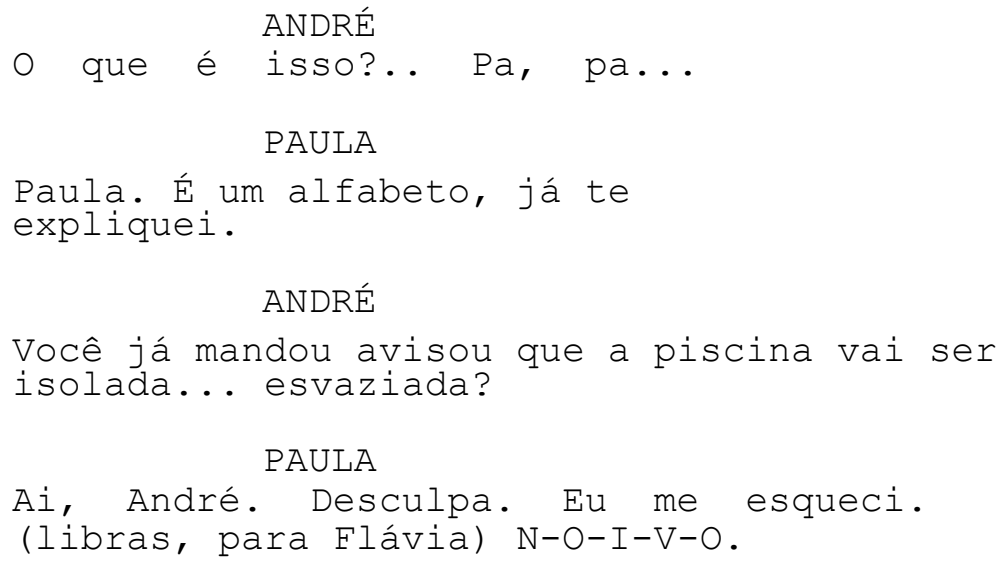




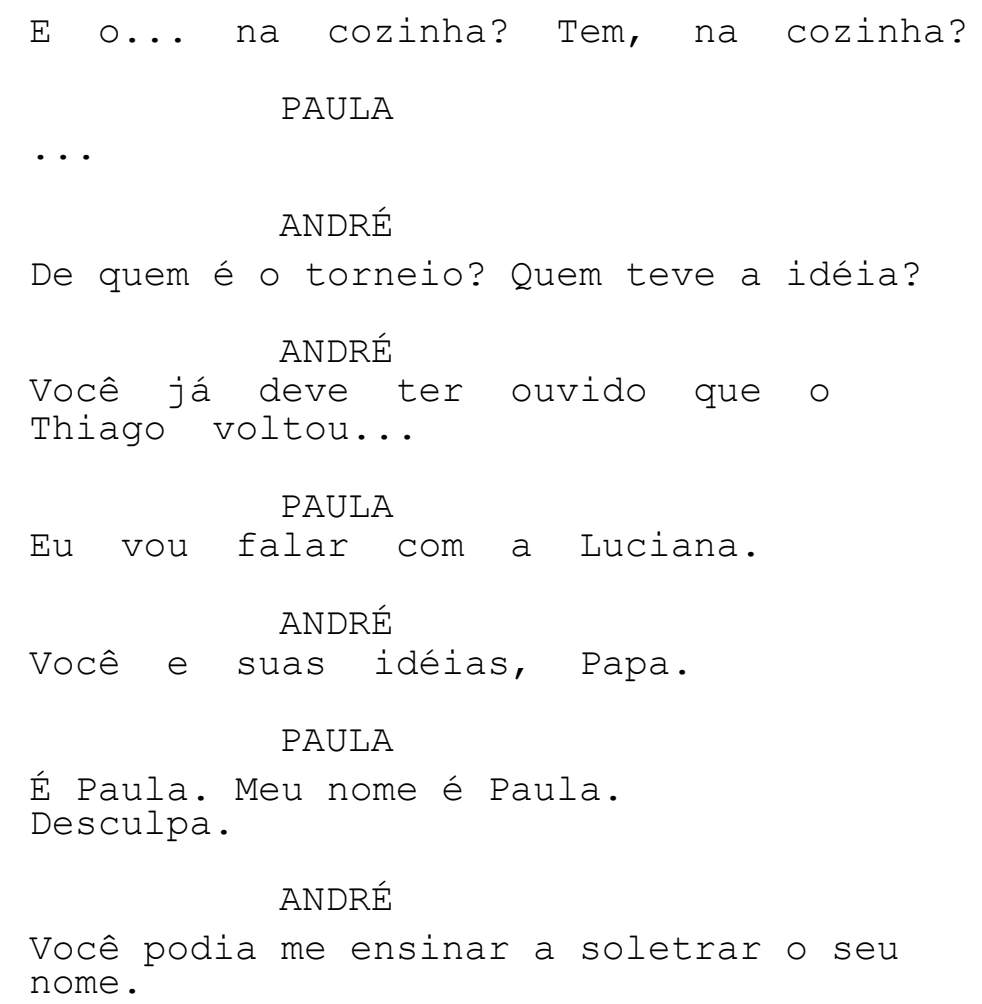

Neste fragmento, podemos perceber que, apesar do discurso pobre e truncado, André é o catalisador de alguns eventos já anunciados em outras trajetórias: ele provoca a separação das irmãs agindo, ora como um noivo que se opõe ao comportamento de Paula com a irmã (a criação do torneio, o retorno de Thiago), ora como uma força disposta a ajudá-la (aprender libras, preparar o clube para o torneio).

André, sendo um vértice de encontro ou de bloqueio entre as personagens, funciona como apoio às trajetórias, seja na forma de um ponto de intersecção ou catalisador de conflitos. Isso, sem dúvidas, contribui para a coesão e compreensão do diagrama complexo que forma a peça. 


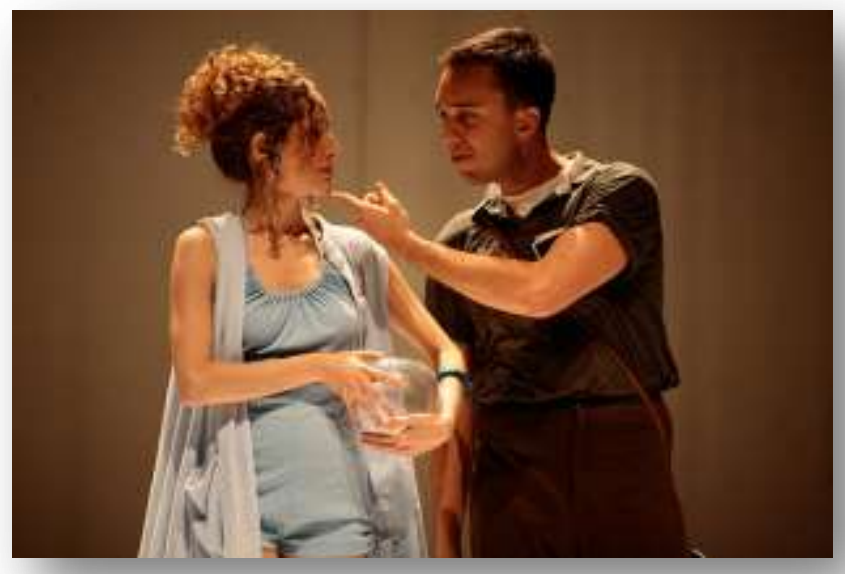

\section{"Experimentações Aquáticas"}

"Palavras Fotografadas"

O mesmo acontece com as trajetórias de Aline e Thiago. As duas funcionam como elementos de intersecção entre as outras trajetórias. Enquanto Thiago é sempre a terceira ponta de diversos triângulos (o triângulo amoroso entre ele, Paula e André; o admirador secreto inventado para aproximar Daniela e Luciana; o assunto desestabilizador entre Maria Amélia e Fernanda), Aline funciona como ponto de fuga e extravasamento de várias personagens (é ela quem promove um primeiro desconforto à imobilidade Daniela, é também com sua ajuda que Luciana consegue cantar pela primeira vez, é ela quem abertamente aponta a inadequação de Flávia).

Paralelamente a esta função de suporte, Thiago e Aline ainda apresentam um relacionamento entre eles bastante particular. Tendo em vista que ela é afásica e que ele não fala, a linguagem utilizada por eles é, em grande parte, cifrada - o que provoca mais um ruído entre a comunicação do espetáculo com o público. Mesmo quando Aline tenta ser intérprete das libras de Thiago para o público, há um ruído em sua fala. Tais ruídos são propositais e equivalem formato da dramaturgia e tema abordado. (Os diálogos estão sempre entre colchetes porque são ditos ou em libras - falas de Thiago - ou com uma certa deficiência na fala - falas de Aline)

\section{ALINE}

[você se incomoda? ficar aqui? Hoje não tem aula de experimentos. Mas eu resolvi vir do mesmo jeito. eu gosto de ficar olhando a piscina.]

\section{THIAGO \\ [eu também. Gosto muito]}




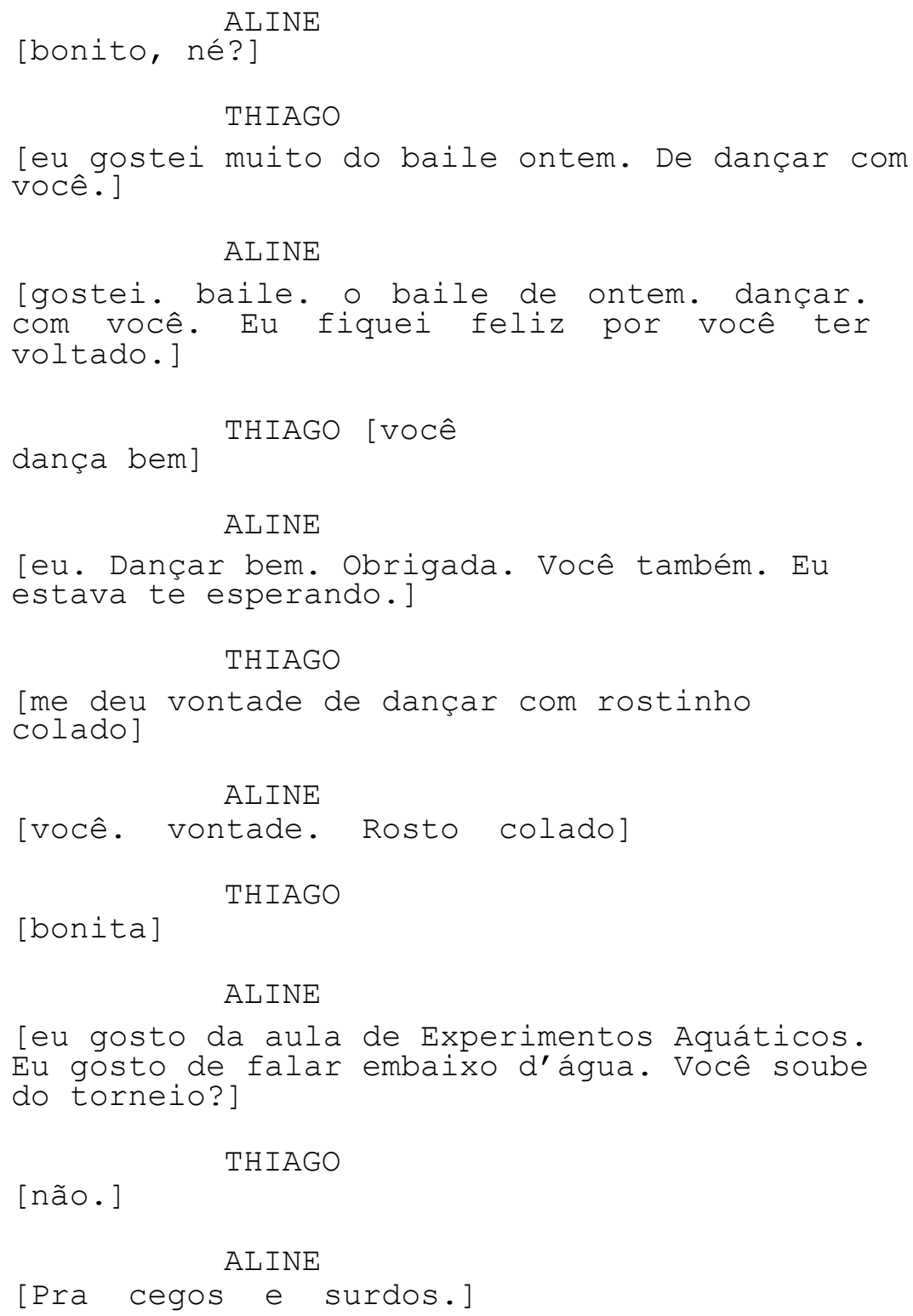

\section{Imersão}

Anteriormente, já foi apontado que poderíamos metaforicamente dizer que a imersão poderia ser entendida em um texto teatral como o estreitamento entre os limites entre realidade e ficção. Em Escuro, esses limites aparecem no hibridismo na linguagem (pela elevação ao primeiro plano de narrativas, didascálicas ou romancização do diálogo) ou na 
utilização de matéria-prima pessoal na criação, ou ainda na construção de uma paisagem dialógica que tensiona o cotidiano.

\section{Ator e Personagem}

Durante toda a criação de Escuro, os atores partiam de sua experiência pessoal para a composição das personagens. As personagens não eram compostas como um outro, mas como uma parte do próprio ator. Assim, não trabalhamos com a construção de uma figura dramática, mas com mudanças de tensão e ritmos de respiração que definissem certas "personalidades." A evidência mais explícita desse processo é que os atores emprestam seus nomes aos personagens.

Associada à camada ficcional criada a partir de textos, fotos e o exercício de entrevistas já descrito, o espetáculo propunha uma reflexão sobre a sua criação: o processo é exposto em cena, numa representação sem intermediários. Os atores, chamados por seus próprios nomes, transitam entre um outro e sua própria experiência.

Durante o processo de trabalho com os atores, os exercícios propostos constituíam em três frentes: o trabalho com a respiração, os níveis de tensão corporal e a junção dos dois através de comparações com a taxonomia das emoções propostas por Darwin.

Quanto a respiração, foram definidos alguns ritmos para experimentação: morte (longa expiração, pausa, longa inspiração, pausa); deserto (respiração com excesso de tensão na glote, longas expirações e inspirações); praia (relaxamento da respiração, com expirações e inspirações longas); o ator (respiração regular); expectativa (inspirações e expirações curtas, com tensão na inspiração); melodrama (respirações curtas com tensão na expiração); tragédia (respirações curtas). O objetivo dos exercícios que envolviam respirações era perceber como outros padrões respiratórios modificavam a percepção do corpo e sugeriam a leitura de uma "personagem"específica. 
Quanto aos níveis de tensão, trabalhamos com a escala proposta em treinamento do Theatre de Complicitè: deserto, bêbado, relaxado, neutro, suspense, melodrama, ópera e tragédia.

Quanto às emoções, trabalhamos corporalmente com as descrições fisiológicas de estados emocionais feitas por Darwin- como medo, raiva, desgosto, tristeza, ciúme, desdém, vergonha, embaraço, surpresa e felicidade. Deve-se esclarecer que não era a tentativa de alcançar determinados estados emotivos mas de, ao reproduzir os indicadores físicos descritos, entender como o corpo respondia a eles e de que forma isso poderia ser associado a momentos particulares de uma improvisação.

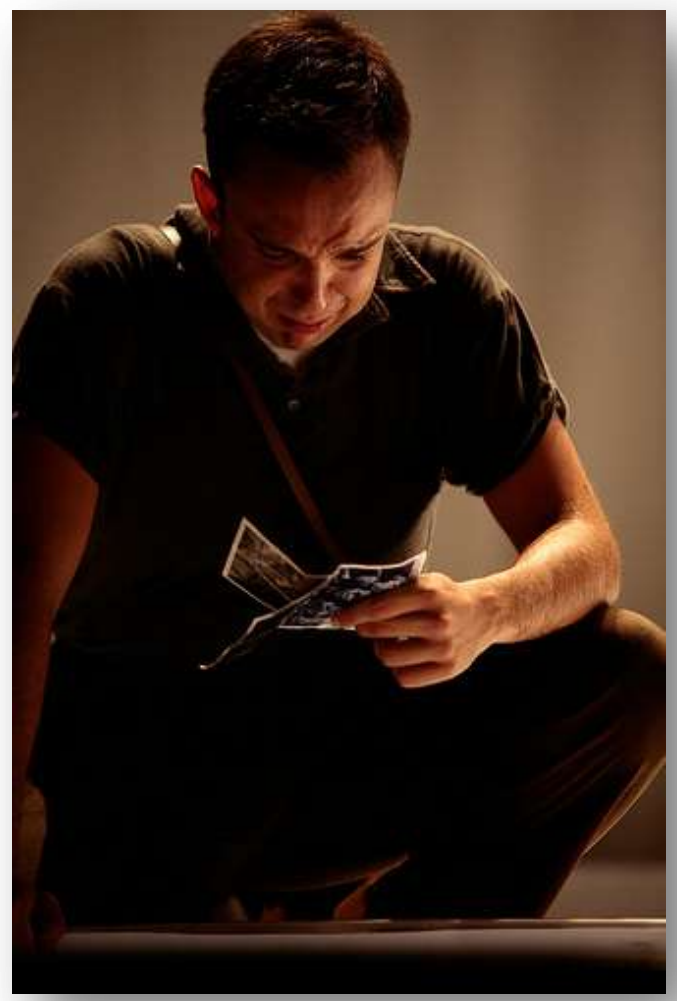

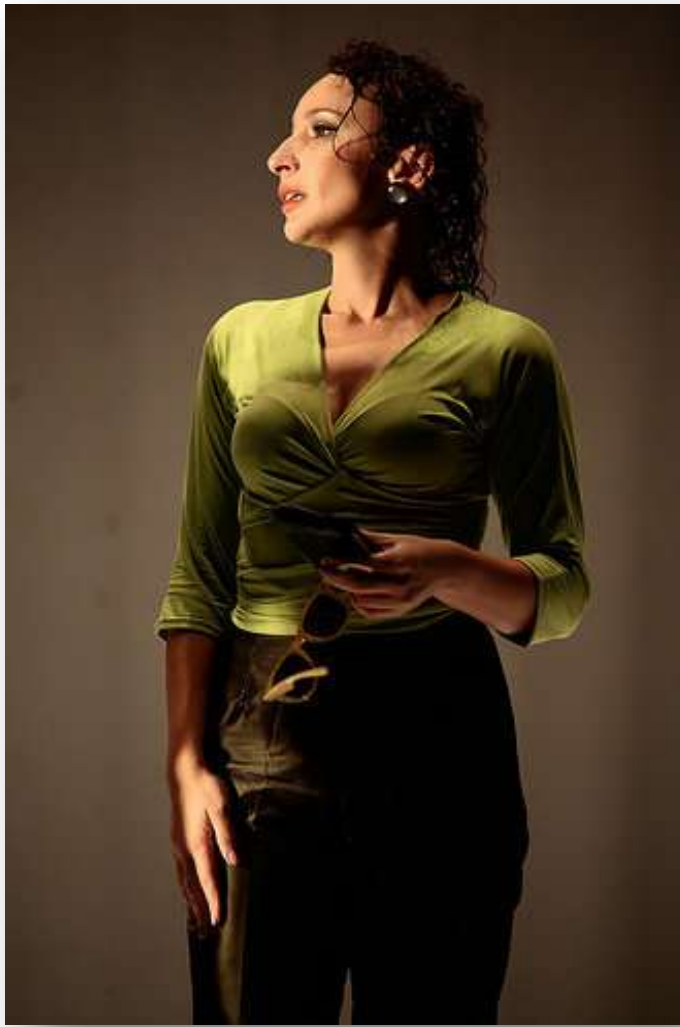

Vale ressaltar que essa relação entre ator/personagem não implica num comodismo que valoriza a pessoalidade do artista e o coloca como eixo da dramaturgia. Nem vem ao caso aqui citar que dados particulares da biografia de cada ator foram utilizados na construção e criação de seu personagem homônimo. Cada ator utilizou suas memórias e vivências para a criação da dramaturgia e, no lugar de compor um personagem, modificou sua respiração para simular um outro que é ele próprio. 
Nas palavras do crítico Luiz Fernando Ramos:

"O fato de os atores emprestarem seus nomes aos personagens - e de vez ou outra narrarem os pensamentos deles entre os diálogos que travam - favorece o desnudamento de qualquer impostação." ${ }^{123}$

A peça propõe, então, uma sobreposição de dois pólos opostos: a ficção proposta pela dramaturgia e a presença dos atores - chamados pelo próprio nome, confundindo o espectador com histórias reais e histórias inventadas.

Embora essa confusão resulte num desaparecimento temporário da figura dramática, não podemos considerá-la como dispositivo que faz desaparecer completamente a ficção, mas antes como estratégia que transforma nossa percepção. O público, assim, é jogado num ambiente de incertezas, um espaço intermediário entre a ficcionalidade de personagens do Clube Atlético Arujá e a materialidade do jogo dos atores. A percepção do público oscila entre ator e personagem. Enquanto os dispositivos da encenação podem dirigir ou até fixar a atenção do espectador na presença dos atores, a dramaturgia abre a possibilidade de que, por vezes, o foco mude para a figura dramática. E vice versa.

Cada vez que essa "oscilação" surge, há uma ruptura, uma descontinuidade. A ordem de percepção que os espectadores construíram é destruída e outra ordem tem que ser estabelecida. Ganha relevância o momento de instabilidade, o intervalo entre as mudanças de percepção,o limiar - a lacuna em que a ordem de percepção é alterada, mas outra ordem ainda não está estabelecida.

Podemos citar uma crítica apresentada por Vicente Concílio, sobre o espetáculo:

\footnotetext{
"Um fato aparentemente simples, explorado pelo texto e talvez pouco explicitado pela encenação, é o de que os personagens possuem o mesmo nome dos atores que os interpretam. Obviamente, não se trata de coincidência; talvez o autor do texto pretenda assumir que aquelas situações e impressões apresentadas estão carregadas de matériaprima oferecida pelos atores. E sendo tão plena dessa pesquisa atoral, sobretudo se levarmos em conta que o projeto artístico deste grupo
}

${ }^{123}$ RAMOS, Luiz Fernando. Crítica publicada na Folha de São Paulo, em 08/12/2009 
visa explorar a idéia de imperfeição e de defeitos pessoais (que os atores provavelmente pesquisam e estabelecem conexões com suas próprias anomalias), porque não explorar a dissonância entre o excessivo cuidado com as aparências, demonstrado pelo zelo com a concepção visual do espetáculo, e o aparente descaso na suposta "construção" dos personagens? Em uma leitura mais atenta, o que poderia parecer preguiça, ganha outros sentidos. Não podemos supor que o autor e diretor estava com preguiça de inventar nomes para seus personagens. É mais apropriado interrogarmos se, nos momentos em que o atores saem do eixo intra-ficcional e falam diretamente ao público, bem como assumem sua pessoalidade ao referirem-se ao seu próprio nome, não estaríamos presenciando uma libertação deles próprios daquele mundo? Daquele ambiente pleno de teatralidade, construído a partir de uma concepção de espaço estilizada e povoada por figuras vestidas e aparamentadas de acordo com a moda dos anos 50 e 60 e que se comportam segundo o padrão convencional daquela época? Não estaria a encenação e o autor apostando na possibilidade de aproximação direta com o público como um momento de revelação, um momento caloroso diante de toda a frieza aparente promovida pela rigidez dos corpos e pela luz azul que emerge da piscina invade o espaço da cena? Dessa forma, "Escuro" põe em xeque a relação atorpersonagem, abrindo margem para questionamentos no âmbito da fiç̧ão que se apresenta em cena. É como se lampejos de teatro performativo (na acepção de Féral) invadissem a cena teatral. Essa invasão promove uma reorganização sobretudo no âmbito do trabalho do ator, que passa a não ser mais aquele que interpreta, mas talvez aquele que mostra talvez um personagem, ou talvez uma figura que, em última análise, pode ser ele mesmo, pode ser o ator exibindo em ato a reflexão que os temas abordados na cena provocam nele mesmo, pode ser que nem exista personagem, apenas auto-reflexão." 124

\section{Primeira e Terceira Pessoas}

De outro modo, a realidade também aparece na própria estrutura do texto, através da transformação de algumas didascálias em diálogos ou na interferência de depoimentos narrativos em terceira pessoa. O personagem/ator fala de si mesmo na terceira pessoa -

${ }^{124}$ CONCÍLIO, Vicente. In on It, Escuro e Festa Separação: da personagem dramática à figura não-mais dramática. Texto apresentado em trabalho acadêmico apresentado à Universidade de São Paulo, ainda não publicado. 
primeira e terceira pessoas coexistem e operam simultaneamente, sem qualquer transferência entre os formatos épico e dramático. Tomemos como exemplo o seguinte fragmento:

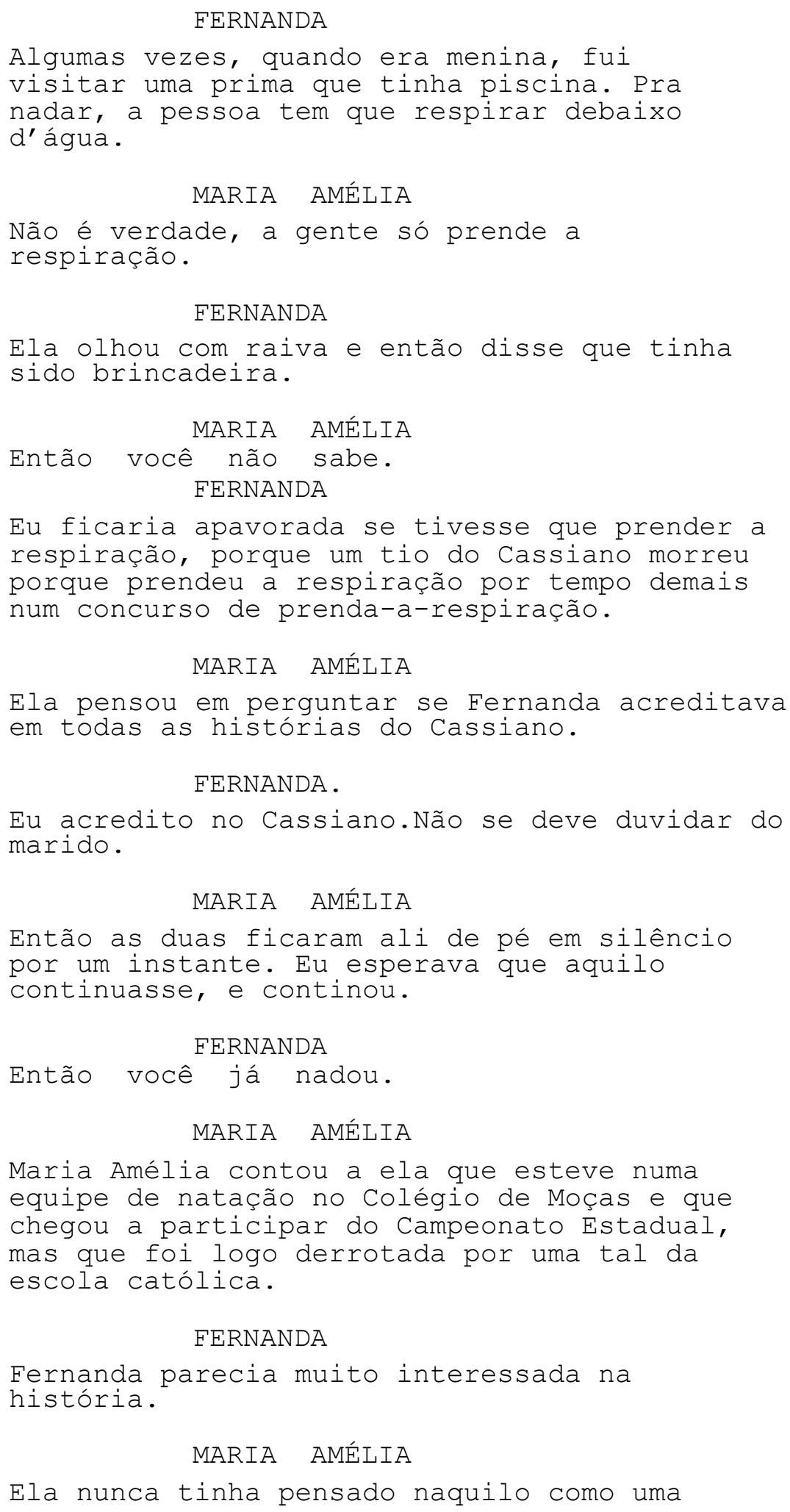




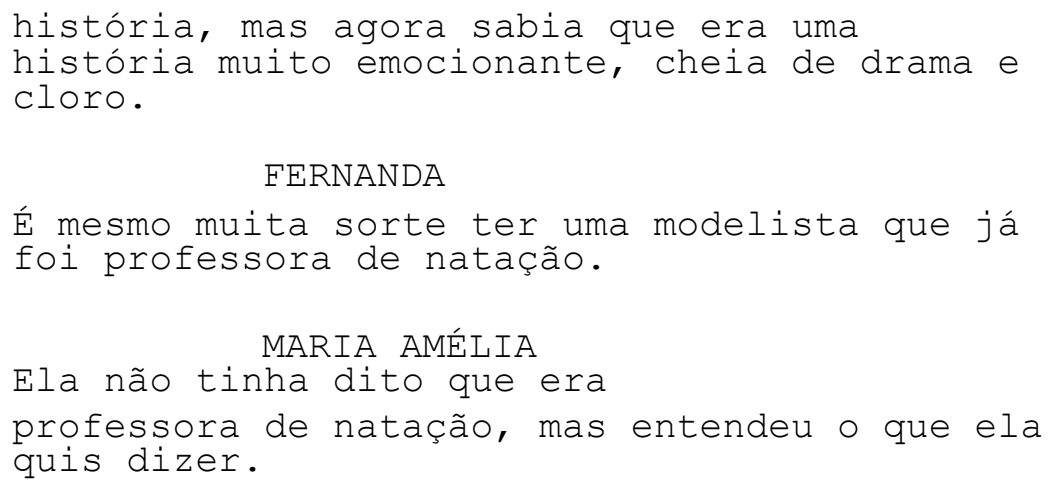

Neste trecho, podemos perceber que não há qualquer transição entre o diálogo e a narrativa em terceira pessoa. As duas fazem parte de um mesmo contexto e, por vezes, são

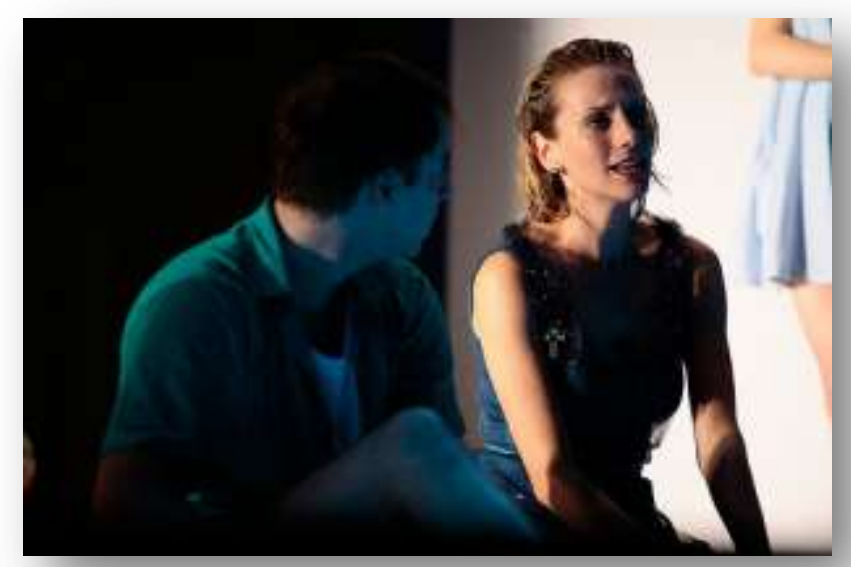
tratadas não como pensamentos externalizados, mas como narrativas que sintetizam a conversa. Numa mesma frase, a atriz alterna entre a primeira e a terceira pessoa. É importante evidenciar que estas frases não são direcionadas à plateia, mas fazem parte do diálogo. É como se a dramaturgia misturasse sem

distinção diálogo dramático, narrativa épica e monólogo interior das personagens. Essa linguagem híbrida é recorrente em todo o texto. Vejamos outro exemplo:

\section{PAULA}

O menino à beira da piscina parecia esperar que ela fosse em frente. E não esperávamos todos?

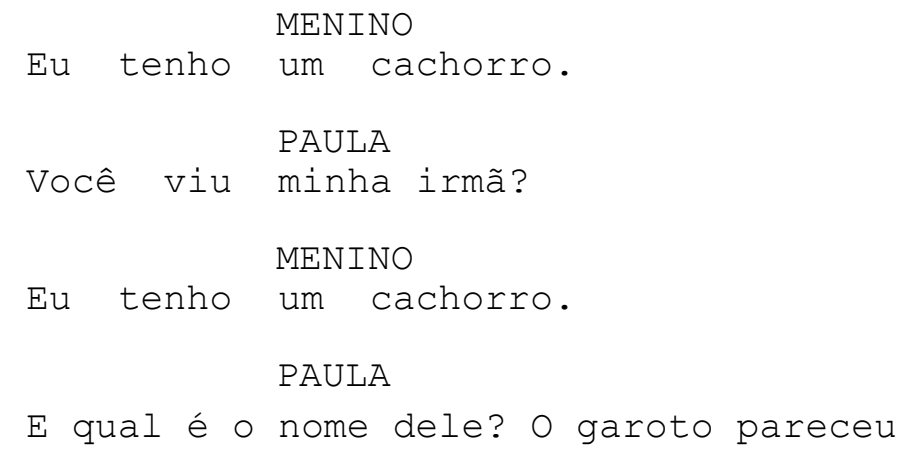




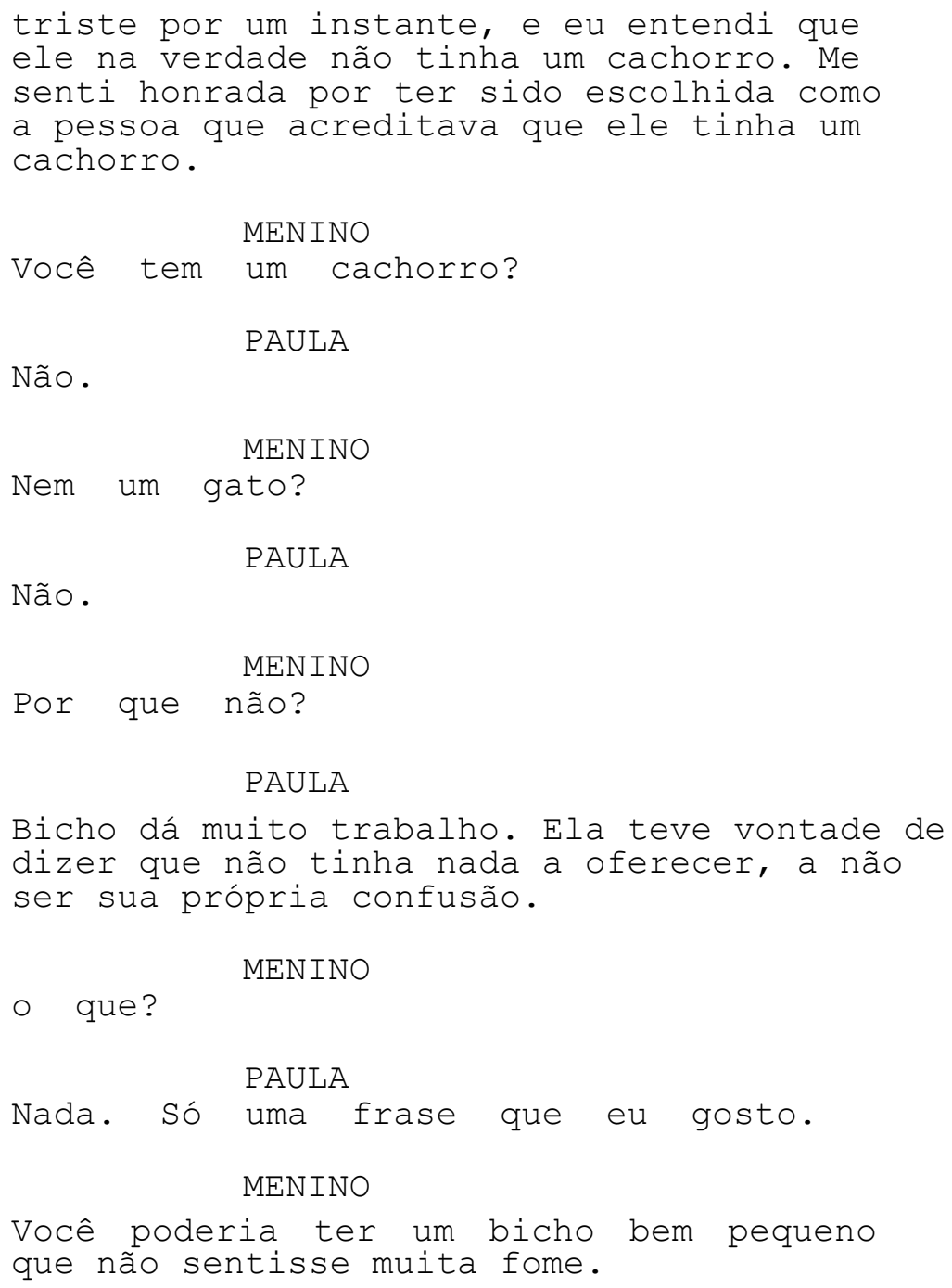

Outra forma que evidencia este hibridismo é a presença de depoimentos em terceira pessoa. Na dinâmica proposta pelo texto, promovem-se momentos em que as personagens abrem mão do diálogo e exploram uma relação discursiva direta com o público.

Esses discursos são feitos utilizando-se a terceira pessoa, porém a carga de subjetividade que apresentam os aproximam de depoimentos da própria personagem, que "deveriam"ser ditos em primeira pessoa. Nestes casos, propõe-se uma irupção de lirismo em meio a diálogos banais. 
Durante todo o processo, chamávamos esses momentos de "aquários", porque era uma espécie de monólogo interior lírico que contrapunha-se à aridez das relações e diálogos (ou a tentativa deles) entre as personagens.

Um exemplo de um deste aquários:

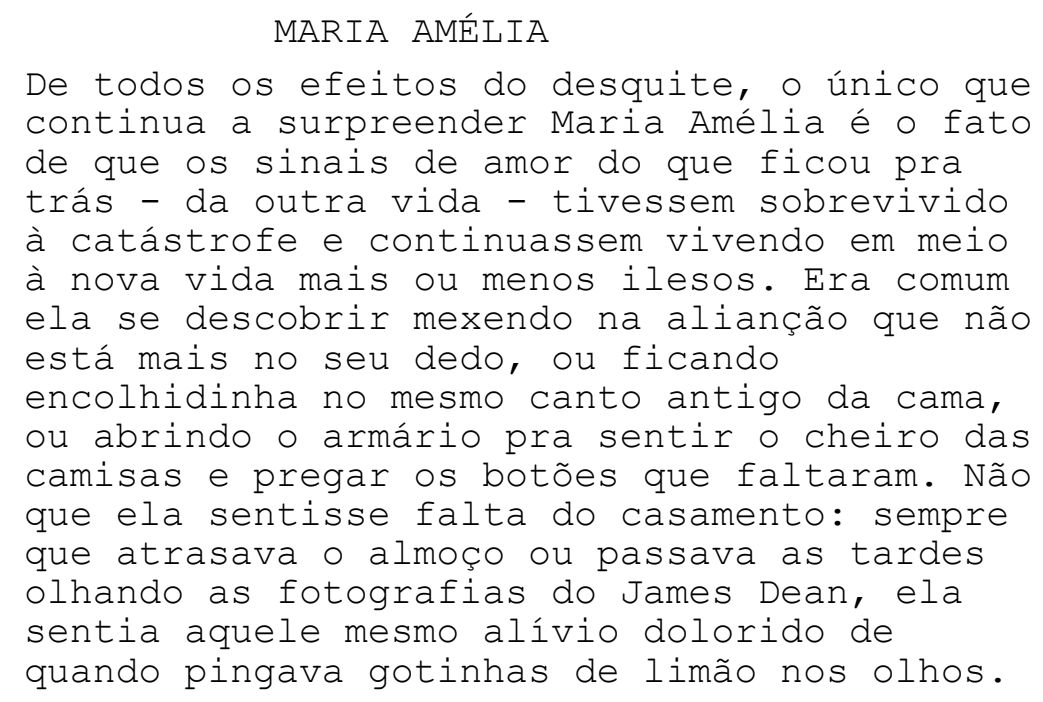

\section{A Composição de uma Paisagem}

Já no programa distribuído durante a primeira temporada do espetáculo em São Paulo, ao lado do depoimento de todos os atores, fica evidente o desejo de que a dramaturgia seja contemplada, isto é, que constitua uma paisagem:

"Leonardo ainda se lembra de ter lido em algum lugar que talvez a imobilidade das coisas que nos cercam seja imposta por nossa certeza de que essas coisas ão elas mesmas e não outras, pela imobilidade do nosso pensamento diante delas. Ele queria contar uma história sem essa certeza: uma dramaturgia repleta de vazios, lacunas, escuros, segredos não ditos, 'hiatos pra quando as palavras se forem'. Como uma fotografia que vai se revelando aos poucos, de acordo com os ângulos escolhidos para contemplá-la, mas que continua cheia de lugares desconhecidos. Uma narrativa que prefere vagar entre 


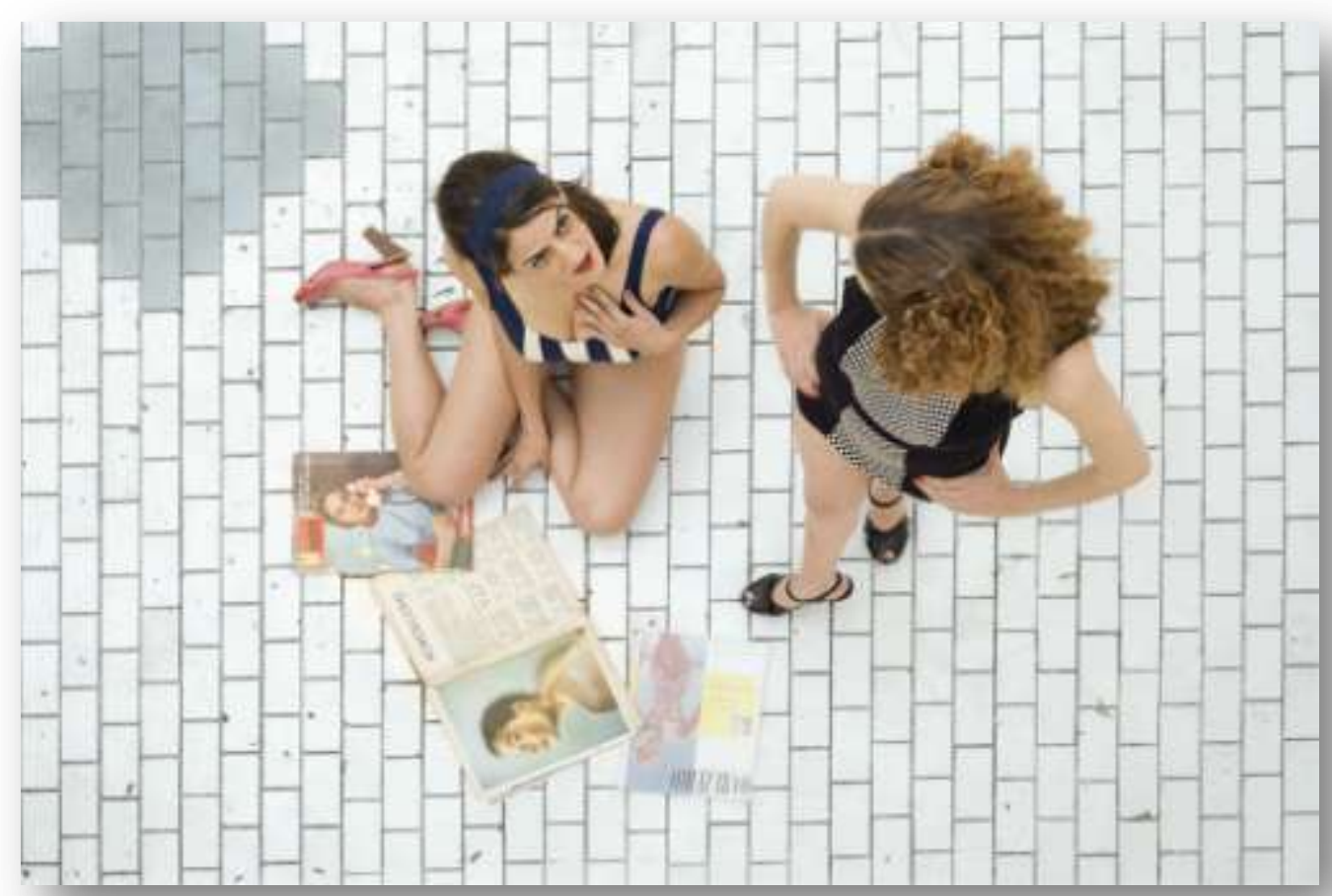

Em todas as cenas de Escuro, havia um esforço em se procurar a "falta de teatralidade": tanto na interpretação, na encenação e, principalmente na dramaturgia. No trabalho dos atores, optou-se por um naturalismo carregado de gestos pouco significativos que iam ganhando uma dimensão abstrata a medida que eram repetidos e refeitos em outros contextos. Em processo, sempre tentamos evidenciar os momentos em que não há uma psicologia atuando e determinando o encontro, mas uma multiplicidade de reações que simulassem o banal. Não há espaço para grandes impostações na voz ou uma teatralização da emoção. Procura-se, sempre, o momento mais ordinário e mais corriqueiro daquelas personagens/atores. Na encenação, procurou-se criar uma paisagem abstrata que pudesse ser tão caleidoscópica como a dramaturgia. Uma piscina fragmentada, vista a um só tempo de cima, de fora e de dentro servia de espaço para que as cenas pudessem ser manipuladas

\footnotetext{
${ }^{125}$ Texto do programa do espetáculo "Escuro", distribuído na primeira temporada, no SESC Pompeia.
} 
livremente de acordo com os agenciamentos propostos. Foram definidas seis áreas de atuação ( que, no agenciamento textual anexo aparecem descritas pelas letras de A a F).

Já na dramaturgia, essa paisagem não-teatral era construída por diálogos que simulavam conversas cotidianas, isto é, não apresentavam coerência discursiva, não tinham a intenção de estabelecer uma relação interpessoal transformadora, promoviam uma confusão de endereçamentos e excluíam a dupla enunciação do discurso (ou seja, o fato dos personagens falarem "coisas que já sabem" apenas para informar o público).

Quanto à esta dupla enunciação, assim a define Anne Ubersfeld,

\begin{abstract}
"Mais do que qualquer outro, o texto de teatro é rigorosamente dependente de suas condições de enunciação; se não é possivel determinar o sentido de um enunciado considerando-s apenas seu componente linguístico, não se levandodo em conta seu componente retórico, ligado à comunicação em que é proferido (...), par ao teatro, a importância do componente retórico é decisiva (...) No interior do texto teatral defrontamo-nos com duas camadas textuais distintas (dois subconjuntos do conjunto textual): uma que tem como sujeito imediato da enunciação o autor e que compreende a totalidade das didascálias (indicações cênicas, nomes de lugares, nomes de personagens), outra que investe o conjunto dos diálogos (inclusive os 'monólogos') e que tem como sujeito mediato da enunciação um personagem. (...) O que é mostrado em toda representação é uma dupla situação de comunicação: a. a situação teatral, ou mais precisamente cênica, em que os emissores são o scriptor e o pessoal do teatro (encenador, atores etc); b. a situação representada, que se constrói com as personagens. ${ }^{126}$
\end{abstract}

Por exemplo:

${ }^{126}$ UBERSFELD, Para ler Teatro. São Paulo, Perspectiva. 2005: p. 158-160) 
LUCIANA

Eu queria saber se vocês vão permitir que fucionários do clube...

ANDRÉ

Você gostaria de participar, é isso, Luciene?

LUCIANA

Queria.

ANDRÉ

Quer dizer que temos uma (pausa) qual o

nome daquele pássaro?

LUCIANA

Pássaro?

ANDRÉ

É. Perdi a palavra. Aquele, que canta. LUCIANA

Sabiá

\section{ANDRÉ}

Não. (cantarola uma música)

LUCIANA

Rouxinol.

ANDRÉ
Isso. Desculpa, perdi a palavra.
Tem que ir no médico. Meu pai....
ANDRÉ

Fui: nada. Me sugeriram um psiquiatra.

LUCIANA

Eu sempre achei que as pessoas vissem um psiquiatra porque estavam tristes. Mas olha pra você: você tem tudo.

ANDRÉ

Ela foi ao psiquiatra.

LUCIANA

Ela?

É, ela. ANDRÉ

Ah.

LUCIANA 


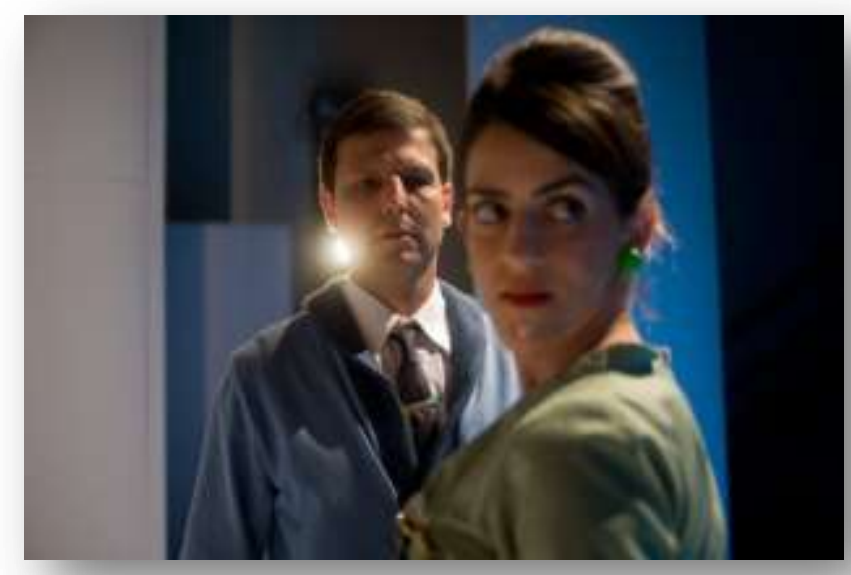

No fragmento acima, percebese claramente uma série de recursos típicos que não possuem um propósito dramático, não revelam desejos ou contra-vontades das personagens. Ao contrário, elas preenchem (e assim ressaltam) 0 vazio daquela comunicação. É uma conversa cheia de implícitos, em que pouco acesso ao assunto da conversa é dado ao leitor (renunciando, portanto, a uma exposição), as falas simulam um cotidiano com estruturas fragmentadas e incompletas, o tempo é dilatado não para criar uma tensão dramática mas para provocar um estranhamento no diálogo.

Deste modo, a paisagem é construída pela palavra e não são excluídos desta paisagem as lacunas, os vazios, as ausências. Segundo a crítica do espetáculo:

"É o que se diz que confirma aquelas vidas como a de seres flutuantes, observáveis em estado líquido, ou que equaliza o que seriam os deficientes aos suficientes. Estão todos imersos na mesma água parada e é dessa consciência dos limites inexoráveis que se impõem sobre eles que advém a força poética do espetáculo."127

\section{Agência}

Já que é um mapa, cada diferente forma de percorrer o hipertexto de Escuro escreve um novo texto. Devemos considerar que o próprio mapa comporta uma série de procedimentos que determinará a navegação. Por seu caráter procedimental, matriz finita de peças teatrais distintas, a atualização em texto dramático acontece pelas escolhas subjetivas dos artistas que interagem com aquela cartografia. As escolhas artísticas feitas são, portanto, os agenciamentos possíveis. Já foi discutida aqui a questão da autoria procedimental e não parece necessário voltarmos a esta discussão.

\footnotetext{
${ }^{R}$ RAMOS, Luiz Fernando. Crítica publicada na Folha de São Paulo, em 08/12/2009
} 
Segue, em anexo, uma primeira hipótese de agenciamento das cenas apresentadas no mapa dramatúrgico "Escuro".

No caso deste agenciamento (que resultou no espetáculo em temporada), optou-se por um tipo de agência que privilegiasse trajetórias dos personagens, destacando diferentes pontos de vista sobre cada situação. Outra opção foram os deslocamentos temporais que explicitavam a simultaneidade e os paralelismos entre as histórias

Os vértices das mudanças de ponto de vista (ou pontos de rotação) são os "segredos contados" ao menino, como veremos. Vejamos um fragmento de como foi percorrido, neste agenciamento, o mapa dramatúrgico:

a. Partimos do encontro final, em que todos os personagens estão à beira da piscina para, através da narração de Luciana no altofalante, estabelecermos um suspense que irá manter a atenção do público à reconstrução da fábula fragmentada;

b. Saltamos, então, temporariamente para a trajetória de Otávio/Menino (que será uma das trajetórias condutoras deste agenciamento). Seguimos Otávio em seu encontro com Maria Amélia (como estamos acompanhando o ponto de vista do Menino/Otávio, não ouvimos o que Maria Amélia diz em seu ouvido) e, depois, sabemos como ele consegue entrar no Clube ludibriando Luciana. A cena é interrompida pela chamado de Luciana (que segue para participar da trajetória de Paula);

c. Ocorre, então, o primeiro deslocamento temporal do espetáculo. Voltamos a assistir o encontro do Menino com Maria Amélia, mas desta vez sob a perspectiva dela. 0 segredo/narrativa dito por ela nos conduz por sua trajetória

d. Trajetória de Maria Amélia, em encontro com Fernanda. Simultaneamente, algumas outras trajetórias acontecem em outros planos do espaço cênico.

e. O discurso de Maria Amélia, ao falar do retratista, nos conduz de volta à trajetória do Menino. O Menino encontra-se com o retratista Thiago. 
f. O Menino cruza com Flávia.

g. Segundo deslocamento temporal. Voltamos temporalmente, ao início da trajetória de Flávia.

h. Flávia está com Paula; Paula chama Luciana (mesmo momento já visto, sob outro ponto de vista em b).

E assim por diante, num constante jogo caleidoscópico entre as trajetórias. Os deslocamentos temporais permitiam que uma mesma cena fosse vista e revista, ampliando nossa percepção sobre cada um dos encontros. Através de simultaneidades e sobreposição de falas, foram criados jogos inusitados, em que uma mesma fala servia a dois contextos diferentes, como por exemplo:

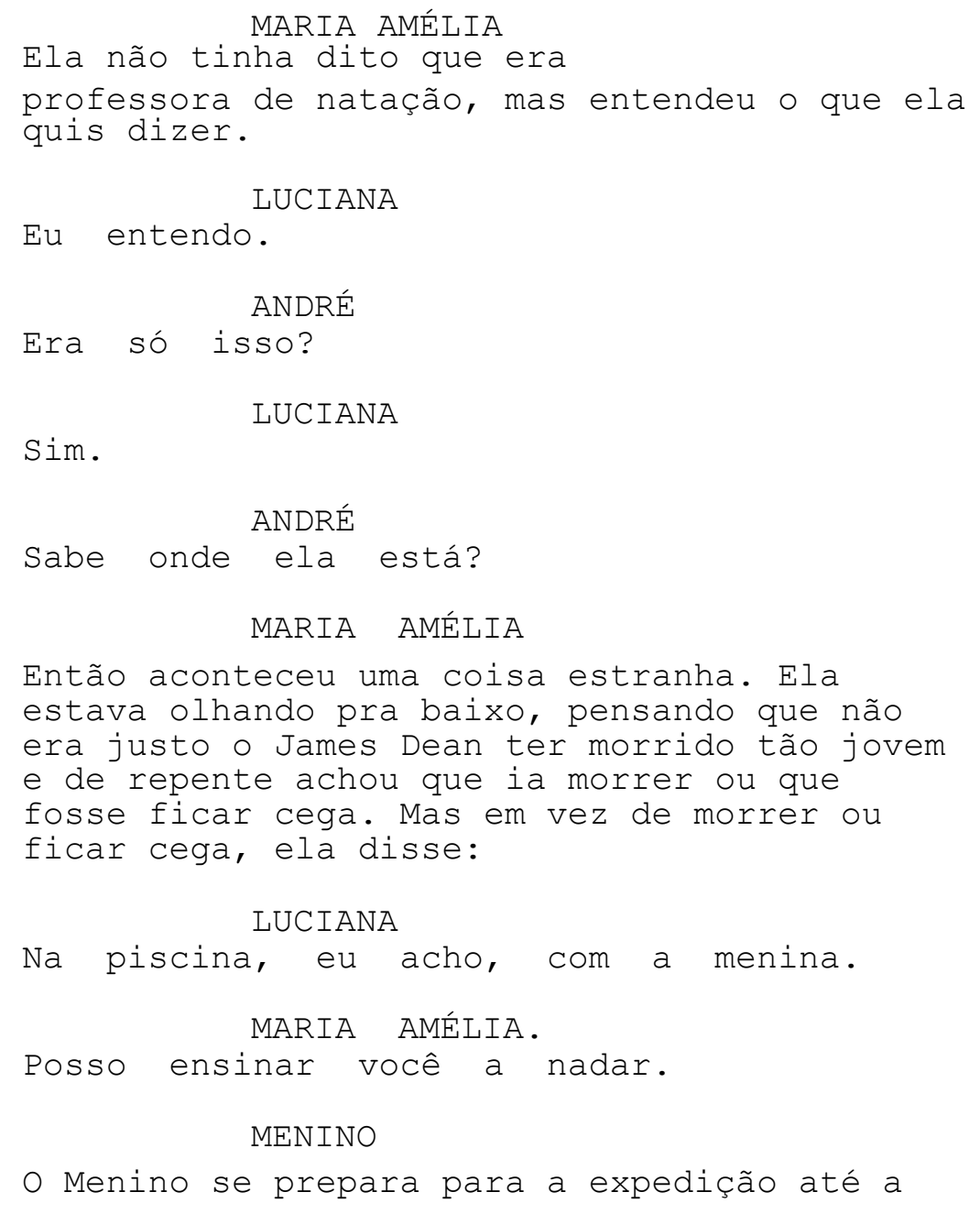




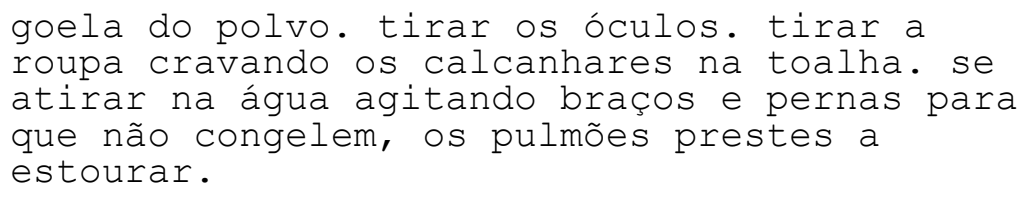

A sobreposição de três contextos diferentes promove um jogo de refração e reflexão entre o situações paralelas, em que o endereçamento das falas e o sentido dos diálogos são

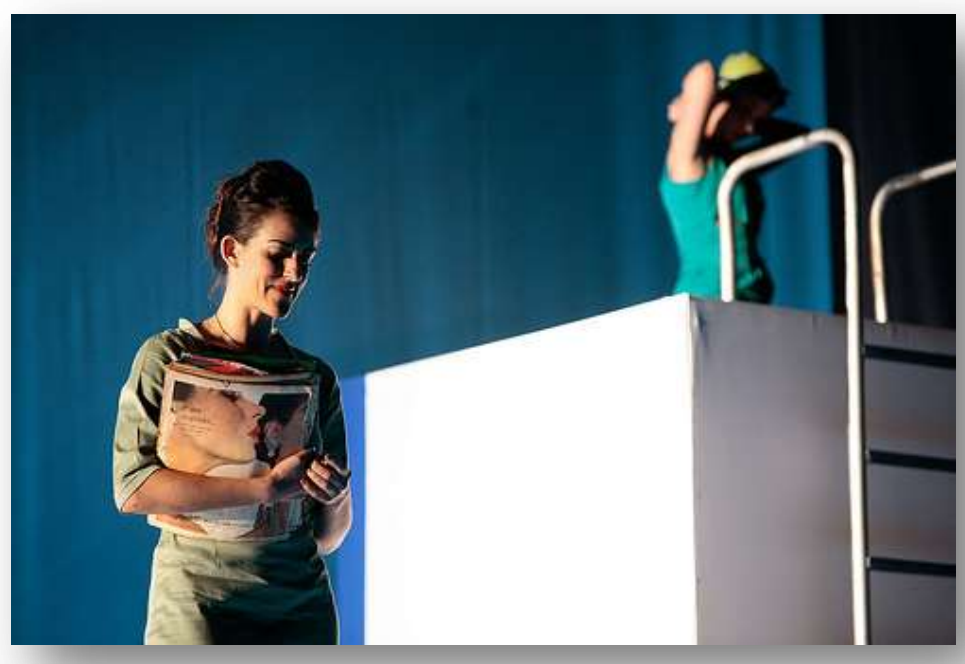
transportados entre cenas. Em um plano, Maria Amélia "entende" o que Fernanda quer dizer. Isso nos dá um link para Luciana "entender" a negativa de André a seu pedido. A narrativa de Maria Amélia serve tanto a sua relação com Fernanda como a descrição das ações de Luciana no intervalo entre a pergunta de André e a sua resposta. Ainda, Maria Amélia oferece-se pra ensinar Fernanda a nadar, enquanto o menino - que não sabe nadar - imagina-se entrando na piscina.

Um agenciamento, portanto, não é somente uma forma de reordenar cenas, mas a possibilidade de recontextualizá-las, de recriá-las. Na década de 1920, o pioneiro do cinema russo Lev Kuleshov ${ }^{128}$ demonstrou que a plateia interpretará uma mesma sequencia da face de um ator, como a representação de fome, dor ou afeição, dependendo de sua justaposição com imagens de uma tigela de sopa, de uma mulher morta ou de uma menina brincando com seu ursinho de pelúcia. Através da agência (e manipulação de um mapa dramatúrgico), podemos utilizar os efeitos observados por Kuleshov para criar justaposições intencionalmente abertas a múltiplas interpretações significativas.

${ }^{128}$ Murray, 2006: 158 


\title{
CONSIDERAÇÕES FINAIS
}

\section{Por uma escrita cúmplice}

\author{
"Cumplicidade é o que nos faz acreditar que \\ enxergamos um mundo em um desenho no \\ chão; ou uma cadeira como uma montanha, $e$ \\ segredos por toda a parte." \\ Simon McBurney
}

Uma escrita cúmplice: esta é a ideia que sustenta toda essa dissertação. Embora muito subjetivo, o conceito de cumplicidade parece se adequar às escolhas aqui apresentadas, porque nos remete tanto à criação colaborativa - o texto sendo escrito em ação nas salas de ensaio, construído por diversas vozes coniventes, em constante - como a agenciamentos, isto é, a linhas de articulação e de fuga, movimentos de convergência e paralelismo.

É também cúmplice esta dissertação, já que ela só se justifica por não entender a pesquisa acadêmica, no sentido de produzir conhecimento, como algo que não passe pela sinceridade e organicidade às atividades desenvolvidas por seu pesquisador. Desse modo, embora incompleto e em constante transformação, o objeto desta pesquisa e as criações artísticas de seu pesquisador não são indissociáveis. Teoria e criação são partes de uma mesma unidade, cúmplices - sujeitos e objetos de uma mesma investigação teatral. A abordagem teórica e a apresentação do texto criado tem, nesse caso, mesmo valor.

Disso, conclui-se que essa dissertação não encerra um estudo mas, ao contrário, abre lacunas para que a experimentação artística e a reflexão teórica continuem de forma vinculada e tomem novos e imprevisíveis caminhos. Poderíamos dizer, inclusive, que a investigação descrita aqui é apenas um primeiro passo para o desenvolvimento de um pensamento sobre a escrita dramática que esteja inscrita em seu tempo. 
Porém, é preciso dizer que ao se propor esta terminologia -escrita cúmplice - não se pretende construir um novo modo de fazer teatral, mas apresentar uma nova perspectiva que possa, por si, abrir possibilidades para uma dramaturgia coerente com nosso tempo: uma dramaturgia que possa ser uma arca, nesses tempos de dilúvio. Se a arca do dilúvio bíblico era única, estanque, fechada, totalizante, as múltiplas arcas do dilúvio de vozes, formas dramatúrgicas e hipernarrativas em que estamos mergulhados dançam entre si. Cada arca abriga pequenas totalidades, mas sem nenhuma pretensão ao universal.

Admite-se que, à deriva no dilúvio de informações e diversidade de linguagens dramáticas (ou pós-dramáticas, ou não dramáticas) coexistentes, uma dramaturgia linear talvez não seja mais suficiente para representar nosso mundo - se é que a isso se pretende uma dramaturgia. Por outro lado, é possível descrever linhas que conectam e tecem a dramaturgia contemporânea num sentido - poderíamos arriscar - de um possível retorno de tradições prédramáticas $^{129}$ na dramaturgia contemporânea, já que, na recorrente batalha entre texto e cena, o primeiro volta a a ganhar força. Seja pela revalorização da fábula, pela exacerbação do lirismo ou pela evidência em cena de sua fisiologia e mecanismos de construção, o texto parece voltar a ter autonomia. Colaborando a este "retorno", também a dramaturgia tem emprestado de outros mares (novelas, filmes, televisão, etc), convidando seus navegantes a unir, sem distinção, texto teatral e performatividade. Ou, na abordagem de Ryngaert:

\begin{abstract}
"Desafiando a antiga dependência na ilusão, os novos dramaturgos pedem a seus leitores e espectadores que assumam uma posição mais perigosa, mais ativa - mais de um jogo do acaso - como um autêntico participante de uma estética que nem é tão nova ( a discussão sobre a palavra "contemporâneo" tem se tornado cansativa) ou tão diferente. Aliás, é uma posição que envolve regressar às tradições prédramáticas." 130
\end{abstract}

\footnotetext{
${ }^{129}$ Em contraposição ao termo "Pós-Dramático" escolhido por Hans-Thies Lehmann.

${ }^{130}$ Tradução livre a partir de: "Changelling the old dependence on illusion, the new playwrights appeal to their readers and spectators to assume a position that is more dangerous, more active - more of a gamble of perhaps as a genuine participant in an aesthetic that is not so much new (discussion of the word 'contemporary' has become tiresome) as different. On occasion, indeed, it is a position that involves returning to pre-dramatic traditions."(RYNGAERT, 2007: 17)
} 
Supõe-se, ainda, que essa escrita dramática - parte de uma extensa diversidade de proposições e estéticas que é a cena teatral contemporânea - é cúmplice porque é direcionada ao navegante e o agenciamento a que nos referimos se dá em suas diversas camadas: na construção prática (através da experimentação coletiva); na sua atualização por encenadores ou atores em constante jogo; e no seu caráter performativo, ou seja, na criação diante (ou com a interação) do público.

O que aqui chamamos de "cumplicidade" evidencia-se também na evidente mistura das funções de leitura e escrita. Definindo o hipertexto como um espaço de percursos para leituras e agenciamentos possíveis, um texto aparece como uma leitura particular de um hipertexto, como um dos caminhos percorridos pelo navegante num mapa de possibilidades.

Por fim, vale ratificar que escrita cúmplice descrita aqui - e que dá início a um pensamento a ser desenvolvido na prática coletiva, junto à experimentações criativas - não é uma linha. Antes, é um mapa. Parafraseando Simon McBurney, um texto dramático é um lugar a ser habitado; tanto origem como destino estão ligados por uma determinada linha narrativa ou de ação. Já um mapa, como é o caso da escrita cúmplice, indica paisagens, sugere múltiplas direções, mas não determina que caminho deve ser tomado. O valor do mapa é ser um guia, não um lugar. Os caminhos dependem dos navegantes. 


\section{BIBLIOGRAFIA}

ABRAMOVIC, Marina. Marina Abramovic. Milão, Ed. Charta, 2002. ABRAMOVIC, Marina. The house with the ocean view. Milão, Ed. Charta, 2003.

ACKERMAN, Alan e PUCHNER, Martin. Against Theatre. Nova York, Palgrave Macmillan, 2006.

ARISTÓTELES. "Poética”. Os Pensadores. São Paulo, Editora Abril, 1973.

ASSIS, Jesus de Paula. Como e por que narrar em ambientes interativos. In: Denise Mattar (org.). O lúdico na arte, pp. 130-136. São Paulo, Instituto Itaú Cultural, 2005.

. Artes do Videogame: conceitos e técnicas. São Paulo, Alameda, 2007.

. Roteiros em ambientes virtuais interativos. Cadernos da Pós-Graduação,

Campinas, v.3, n.1, pp 93-110, 1999.

AUTIER, Michel e LÈVY, Pierre. As árvores de conhecimentos. São Paulo, Edições Loyola, 1998.

BACHELARD, Gastón. Poética do Espaço. São Paulo: Martins Fontes, 1990.

BENTLEY, E. A experiência viva do teatro. Rio de Janeiro: Zahar, 1967.

BERTHOLD, M. História mundial do teatro. São Paulo: Perspectiva, 2000.

BOGART, Anne e LANDAU, Tina. The Viepoints Book: A pratical Guide to Viewpoints and Composition. New York, Paperback, 2005.

BORDWELL, David. "Poetics of Cinema." Berkeley: University of California Press. 2008 - "Mutual Friends and Chronologies of Chance" - p. 189-250

. Narration in the Fiction Film. London: Routledge, 1985.

; Janet Staiger e Kristin Thompson. The Classical Hollywood Cinema. New

York: Columbia University Press, 1985.

BORGES, Jorge L. Fiç̧ões. São Paulo, Globo, 1989.

BRADBY, David: "Michel Vinaver and A la Revenverse: Between Writing and Staging", The Transparency of the Text : Contemporary Writing for the Stage, Yale French Studies, 112, 2007.

BROOK, Peter. O Ponto de Mudança. Rio de Janeiro, Civilização Brasileira, 1994.

CARLSON, M. Teorias do teatro: estudo histórico dos gregos até a atualidade. São Paulo: Unesp, 1997..

CASTELLUCCI, Claudia e Romeo. Les Pèlerins de la matière. Besançon: Les Solitaires intempestifs, 2001. 
CHAMBERLAIN, F. Jacques Lecoq and the British Theatre. Contemporary Theatre Studies, 42. New York, Routledge, 2002.

CHARTIER, Roger. A aventura do livro, do leitor ao navegar. São Paulo, Editora UNESP, 1998.

CHECKOV, M. Para O Ator. São Paulo: Martins Fontes, 1996.

COHEN, Renato. Performance como linguagem. São Paulo, Perspectiva, 1989. . Work in progress na cena contemporânea. São Paulo, Perspectiva, 1998.

CONCÍlIO, Vicente. In on It, Escuro e Festa de Separação: da personagem dramática à figura não-mais dramática. (não publicado), 2010.

CORTÁZAR, Julio. O Jogo da Amarelinha. Rio de Janeiro, Civilização Brasileira, 2002.

COTTON, Bob \& OLIVER, Richard (1993). Understanding Hypermedia - from multimedia to virtual realiality. Phaidon Press Ltda, London.

CRAWFORD, Chris. On Interactive Storytelling. Indianapois, New Riders, 2005.

DELEUZE, Gilles e GUATTARI, Félix. "Como criar para si um corpo sem órgãos". In Mil platôs. Capitalismo e esquizofrenia. Vol. 3. São Paulo,Editora 34, 1999, p.9-29.

esquizofrenia. Lisboa, Assírio \& Alvim, 1966.

. "O corpo sem órgãos". In O Anti-Édipo. Capitalismo e . Mil Platôs (Vol. 1). São Paulo, Ed. 34, 1999.

DORT, Bernard. La représentation émancipée. Paris, Actes Sud, 1988, p. 171-184.

ECO, Umberto. Obra Aberta. São Paulo, Perspectiva, 1991.

. Seis Passeios pelo Bosque da Ficção. São Paulo, Perspectiva, 1991.

FÉRAL, Josette (org). Théâtralité, écriture et mise en scène. Québec,Ed.Hurtubise, 1985.

. "Moving Across Languages", In The Transparency of the Text : Contemporary Writing for the Stage, Yale French Studies, 50, 2007.

. "Performance and theatricality: the subject demystified". In MURRAY, Thimothy. Mimesis, masochism \& mime. The politics of theatricality in contemporary French thought. Ann Arbor, The University of Michigan Press, 1997, p. 289-300.

. "Por uma poética da performatividade: o teatro performativo", in Sala Preta, no 8, 2008, PPGAC-ECA-USP, PP. 197- 210.

FERNANDES, S. T. Teatralidades Contemporâneas In. Texto e imagem: estudos de teatro, Org. 
Perspectiva/Edusp, 2006.

e AUDIO, Roberto (org.) Teatro da Vertigem. BR-3. São Paulo, FIELD, Syd. Screenplay: The Foundations of Screenwriting, 1979, Rio de Janeiro: Objetiva, 1995. FISCHER-LICHTE, Erika. "Reality and Fiction in Contemporary Theatre", in "Fictional Realities / Real Fictions" Editado por Mateusz Borowski e Malgorzata Sugiera - Cambridge Scholars Publishing - 2006 . "The Transformative Power of Performance - a new aesthetics". Tradução de Saskya Iris Jain, Routledge, Londres, 2005.

GIANNACHI, Gabriella. On Directing. New York, St. Martin's Griffin, 1999.

GROTOWSKI, J. Em Busca do Teatro Pobre. Rio de Janeiro: Civilização Brasileira, 1992.

GUINSBURG, J. e FERNANDES, S. O Pós-dramático. São Paulo: Perspectiva, 2009.

LANDOW, G. Hypertext - The Convergence of Contemporary Critical Theory and Technology. 1992

LAURENTIZ, Sílvia. Imagens Animadas, tese de Doutorado, COS-PUC/SP. 1999

LEÃO, Lúcia. "A complexidade da Hipermídia" in O Labirinto da Hipermídia, lluminuras, SP, p. 55- 77. 1999

LEHMANN, Hans-Thies. O teatro pós-dramático. São Paulo, Cosac\&Naify, 2007.

LÉON, Federico. Registros: Teatro Reunido e Otros Textos. Buenos Aires: Adriano Hidalgo Editora, 2005.

LÈVY, Pierre. As tecnologias da inteligência. São Paulo, Ed. 34, 1999.

. Cibercultura. São Paulo, Ed. 34, 1999.

. O Que é Virtual? São Paulo, Ed. 34, 1999.

Loyola, 1998.

A ideografia dinâmica: rumo a uma imaginação artificial? São Paulo, Edições

Loyola, 1998.

. A inteligência coletiva: por uma antropologia do ciberespaço. São Paulo, Edições

LOPES, Elisabeth Silva. A performance da memória. Sala Preta - Revista de Artes Cênicas da USP, N. 10, 2010.

MCBURNEY, Simon e COMPLICITE, Theatre de. Complicite Plays 1: Street of Crocodiles, Mnemonic, Three Lives of Lucie Cabrol. London, Methuen, 2004. 
MOUNSEF, Donia, Josette Féral (org) The Transparency of the Text : Contemporary Writing for the Stage, Yale French Studies, 112, 2007.

MURRAY, Janet H. Hamlet no Holodeck: o futuro da narrativa no ciberespaço. São Paulo, Itaú Cultural: Unesp, 2003.

NESTROVSKI, Arthur (ed.) Teatro da Vertigem. Trilogia Bíblica. São Paulo, Publifolha,2002.

PAVIS, Patrice. Dicionário de teatro. Trad. J. Guinsburg e Maria Lúcia Pereira. São Paulo: Perspectiva, 1999.

PELBART, Peter Pál. "Esquizocenia". In Vida capital. Ensaios de biopolítica. São Paulo, Iluminuras, 2003, p. 145-150.

PLAZA, Júlio. "Arte e interatividade: Autor-obra-recepção", in Revista do Mestrado em Arte e Tecnologia da Universidade de Brasília, VIS, v. 3, n.3, UnB, p. 29-42. 2001

PROPP, Vladimir I. Morfologia do Conto Maravilhoso. Tradução de Jasna Paravich Sarhan. Rio de Janeiro: Forense-Universitária, 1984.

REWALD, Rubens. Caos Dramaturgia. São Paulo, Perspectiva; Fapesp, 2005

ROSENFELD, Anatol. O Teatro Épico. São Paulo, Perspectiva, 1998. . Texto/Contexto. São Paulo: Perspectiva, 1969

ROUBINE, J-Jaques. A linguagem da encenação teatral. Rio de Janeiro: Jorge Zahar, 1998;

RYNGAERT, Jean-Pierre. "Speech in Tatters : The Interplay of Voices in recent Dramatic Writing", In The Transparency of the Text : Contemporary Writing for the Stage, Yale French Studies, 112, 2007.

. Ecritures théâtrales contemporaines : état des lieux., Pratiques « Les Ecritures théâtrales ॥, N¹19-120, Décembre 2003.

111-123.

"Encarnar fantasmas que falam". In Revista Cena, no 6, UFRGS, PP. . Introdução à Análise do Teatro. São Paulo, Martins Fontes, 1996.

SARRAZAC, Jean-Pierre (org.) Lexique du drame moderne et contemporain. Paris, Circé, 2005, p.214-218.

. L'invention de la théâtralité e La leçon des maîtres. In. Critique du théâtre. De l'utopie au désenchantement. Paris : Circé, 2000, P. 53-71 e 113-139.

SZONDI, Peter. Teoria do drama moderno (1880-1950). Trad. Luís Sérgio Repa. São Paulo: Cosac \& Naify Edições, 2001. 
TAN, Ed S.. Emotion and the Structure of Narrative Film: Film as an Emotion Machine. Tradução de Barbara Fasting. Mahway, New Jersey: Lawrence Erlbaum Associates, Publishers, 1996.

THOMPSON, Kristin. Storytelling in the New Hollywood. Londres: Harvard University Press, 1999.

TREILHOU-BALAUDÉ, C. La scène et les images. In. Revue des estudes théâtrales, Registrs/8. Paris: Sorbonne Nouvelle, 2003.

UBERSFELD, Anne. Para ler Teatro. São Paulo : Perspectiva, 2005.

VINAVER, Michel. Dissidente; O Programa de Televisão: tradução, apresentação e notas de Catarina Sant'Anna. São Paulo: EDUSP, 2007.

WALTON, Stuart. Uma história das emoções. Rio de Janeiro: Record, 2007. 
ANEXOS

1. Um possível agenciamento 


\section{Mapa Dramatúrgico de “ESCURO”}

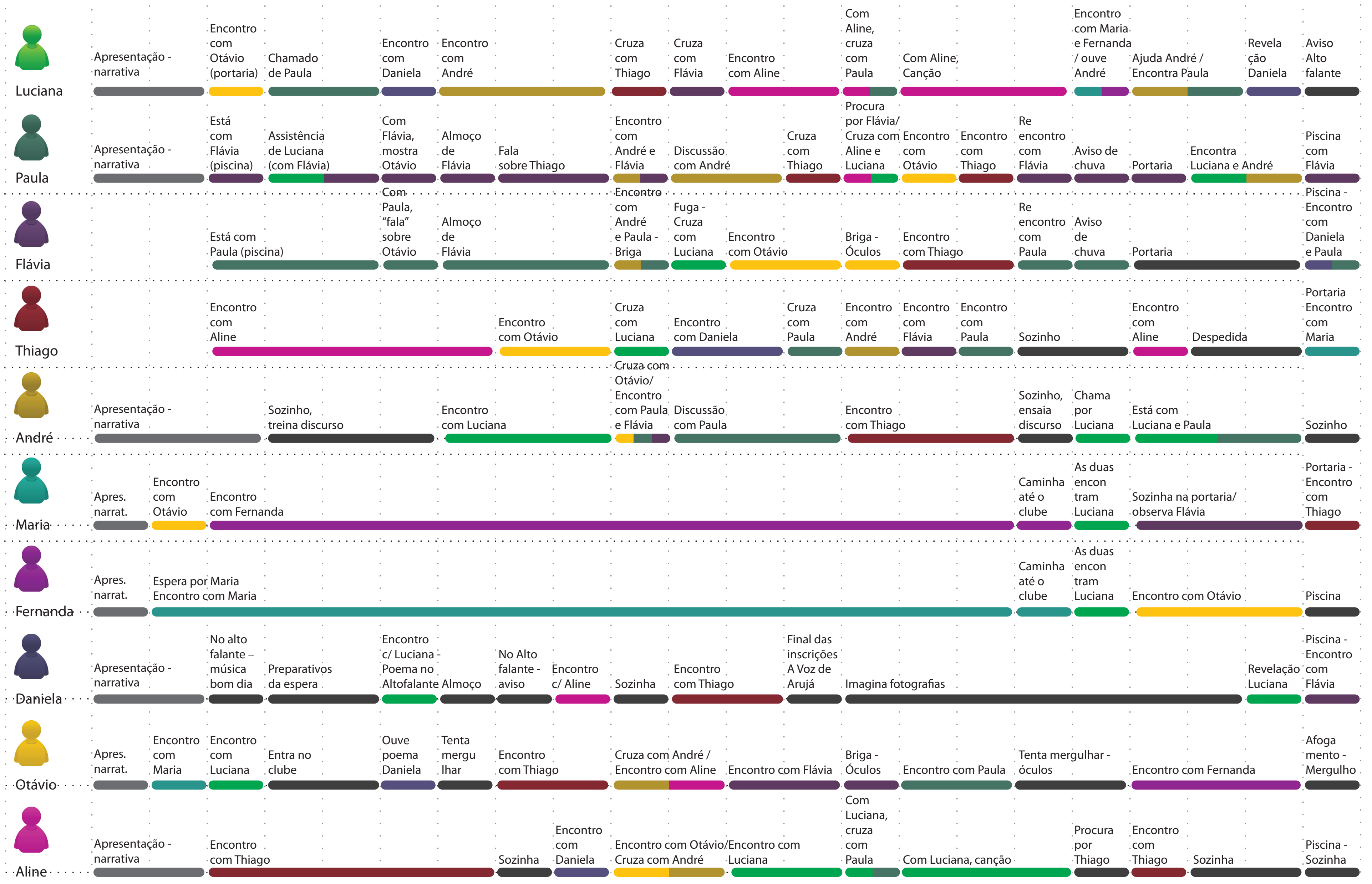




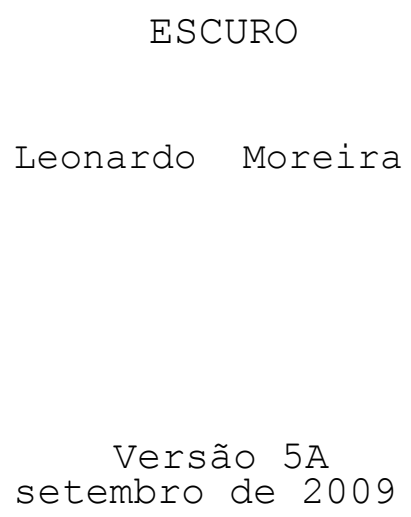

Colaboraram com a criação: Aline Filócomo, André Blumenschein, Daneila Duarte, Fernanda Stefanski, Flávia Melman, Luciana Paes, Maria Amélia Farah, Otávio Dantas, Paula Picarelli e Thiago Amaral.

O texto faz ainda referência a fragmentos de Alan Pauls, Miranda July, Jonathan S. Foer, F. S. Fitzgerald, M. Haddon, Helen Keller, K. Mansfield e Michael Weiner. 
I - PRÓLOGO

B. O.

(v.o)
Gostaríamos também de agradecer a
todos pela presença no nosso já
tradicional Sábado Dançante
(pausa) tradicional Sábado
Dançante realizado ontem. E por
fim, a Diretoria do Clube Atlético
Arujá vem pedir desculpas a todos
mas, em função da chuva, o Torneio
de Natação para Cegos e Surdos e o
Concurso A Voz de Arujá terão que
ser adiados. As atividades que
aconteceriam hoje em comemoração à
emancipação política de nossa
querida comarca serão transferidas
para amanhã: 19 de fevereiro.
(pausa) Pessoalmente, gostaria de
lembrar a todos que a apresentação
da carteira de sócio do clube é
imprenscindivel para o uso da
piscina. Boa tarde a todos, a
Diretoria.

Longa Pausa

\section{LUCIANA}

Por favor, saiam da piscina. Afastem-se da piscina imediatamente. Alguém, por favor, ajudem a socorrer. Aconteceu um acidente na piscina. Por favor, por favor...

CENA 2

Baile. Coreografia. Dança e segredos para o Menino.

II - TRAJETÓRIAS

A EQUIPE DE NATAÇÃO

Apenas o MENINO permanece em (D), com seu aquário, terminando de passar uma última linha na agulha. MARIA AMÉLIA se aproxima em (B). 


\section{Dona Maria!}

\section{MENINO}

O MENINO corre até ela, que faz um sinal para que ele não grite. Verifica se alguém a viu. Os dois estão em (B) . Vemos MARIA AMÉLIA de costas, bem perto do MENINO. Ele lhe entrega um pequeno pacote e ela confere, bem de perto, algumas agulhas.

\section{MENINO}

Pode ver: passei tudo direitinho. Todas as cores de linha que a senhora pediu. Acabei agora.

\section{MARIA AMÉLIA}

Estou vendo. Você não mostrou pra ninguém, mostrou? Olha o que eu prometi (entrega uma pequena bola pra ele).

\section{MENINO}

É difícil pra senhora enxergar o buraquinho, né?

\section{MARIA AMÉLIA}

Você está indo pro Clube? Vai nadar hoje?

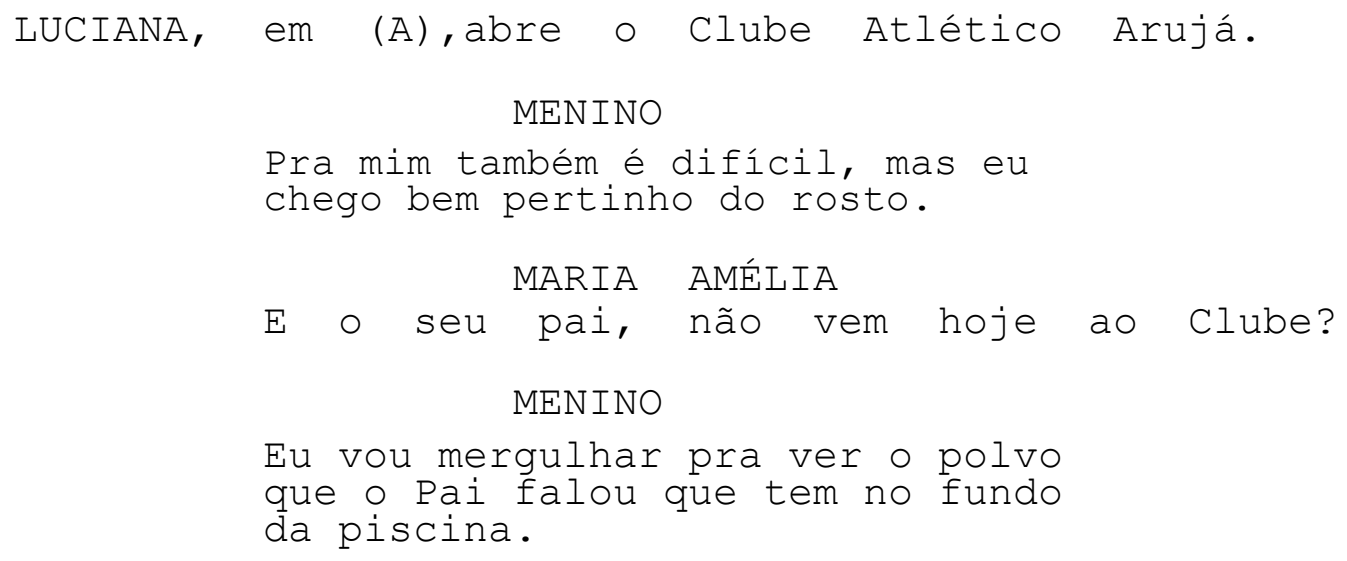

DANIELA aparece em (E), carregando seu aquário e uma bolsa. Ela coloca a bolsa no chão e prepara-se para falar no aquário. ALINE, em (A), entra no Clube, mostrando a carteirinha a LUCIANA.

MARIA AMÉLIA se aproxima do ouvido do MENINO e sussurra algo que não ouvimos.

\section{MENINO}

Numa idade em que as crianças ficam desesperadas pra falar, o menino 
MENINO

pode passar horas só ouvindo. Tem

nove anos debaixo dos grandes

óculos, ou foi o que lhe disseram.

MARIA AMÉLIA se afasta, surpreendida pelo que acabou de dizer.

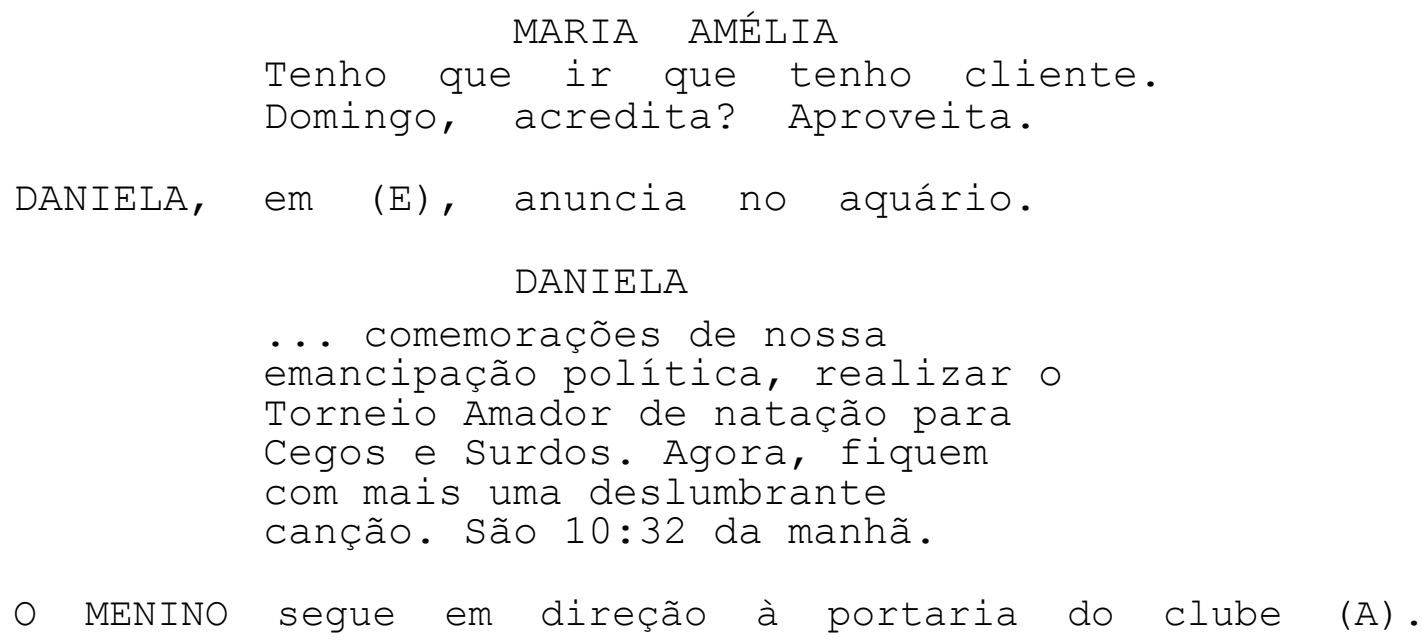

A VOZ DE ARUJÁ

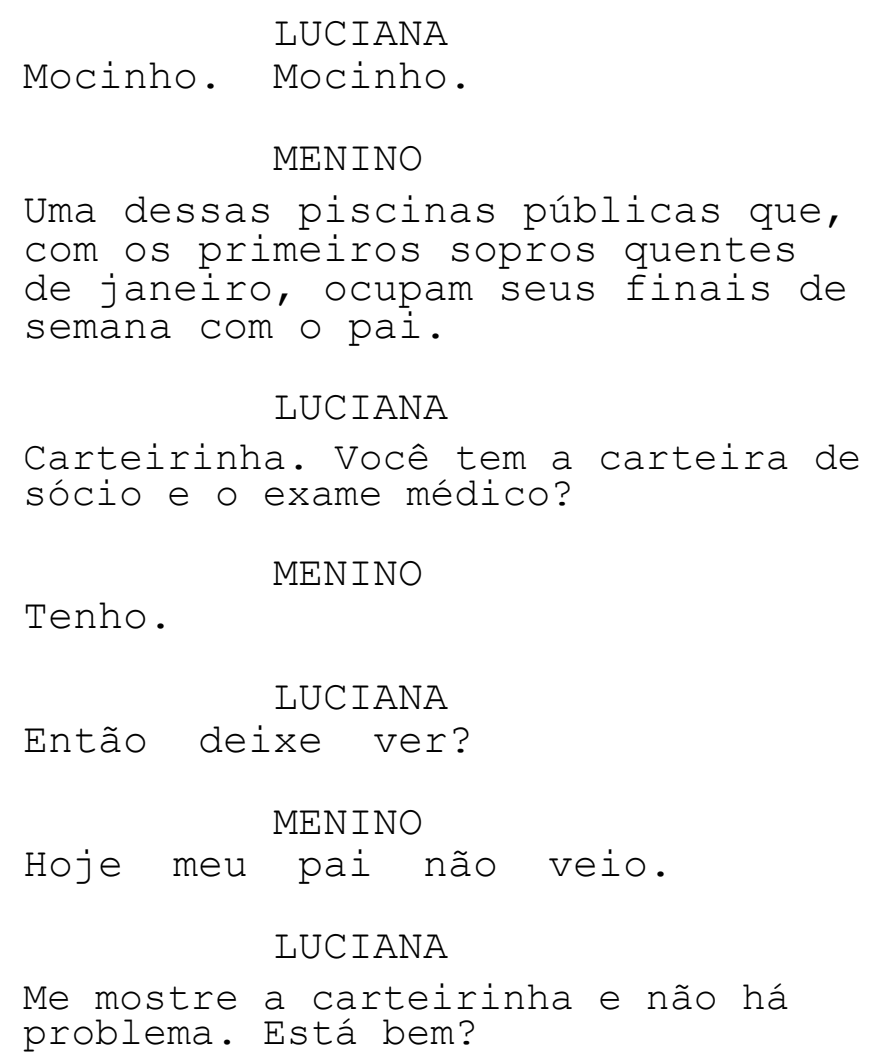




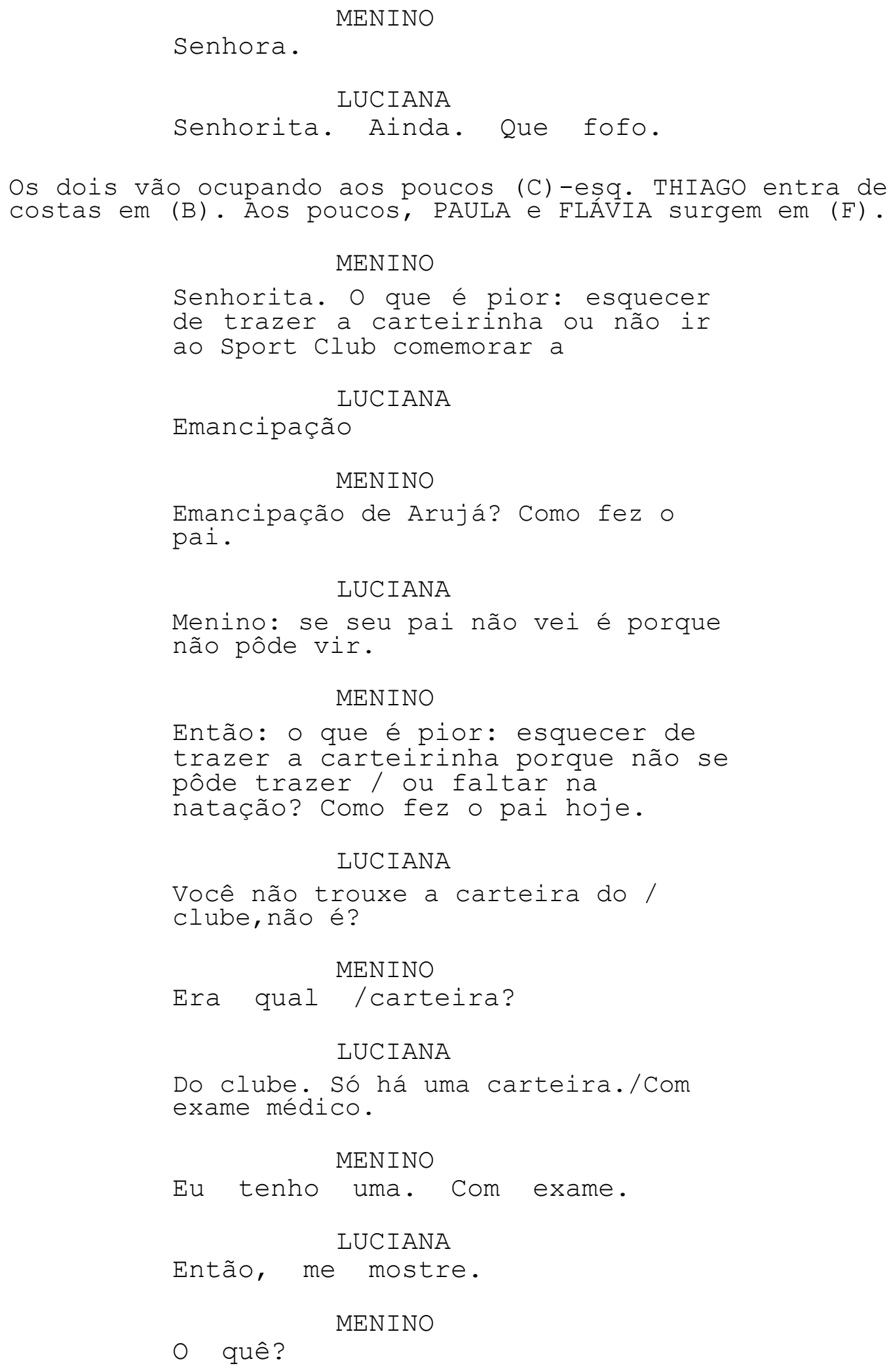


LUCIANA
A carteira / de sócio.
MENINO
A carteira eu não trouxe. Só o exame.

ALINE se aproxima de THIAGO em (B). Ambos de costas, olham a piscina.

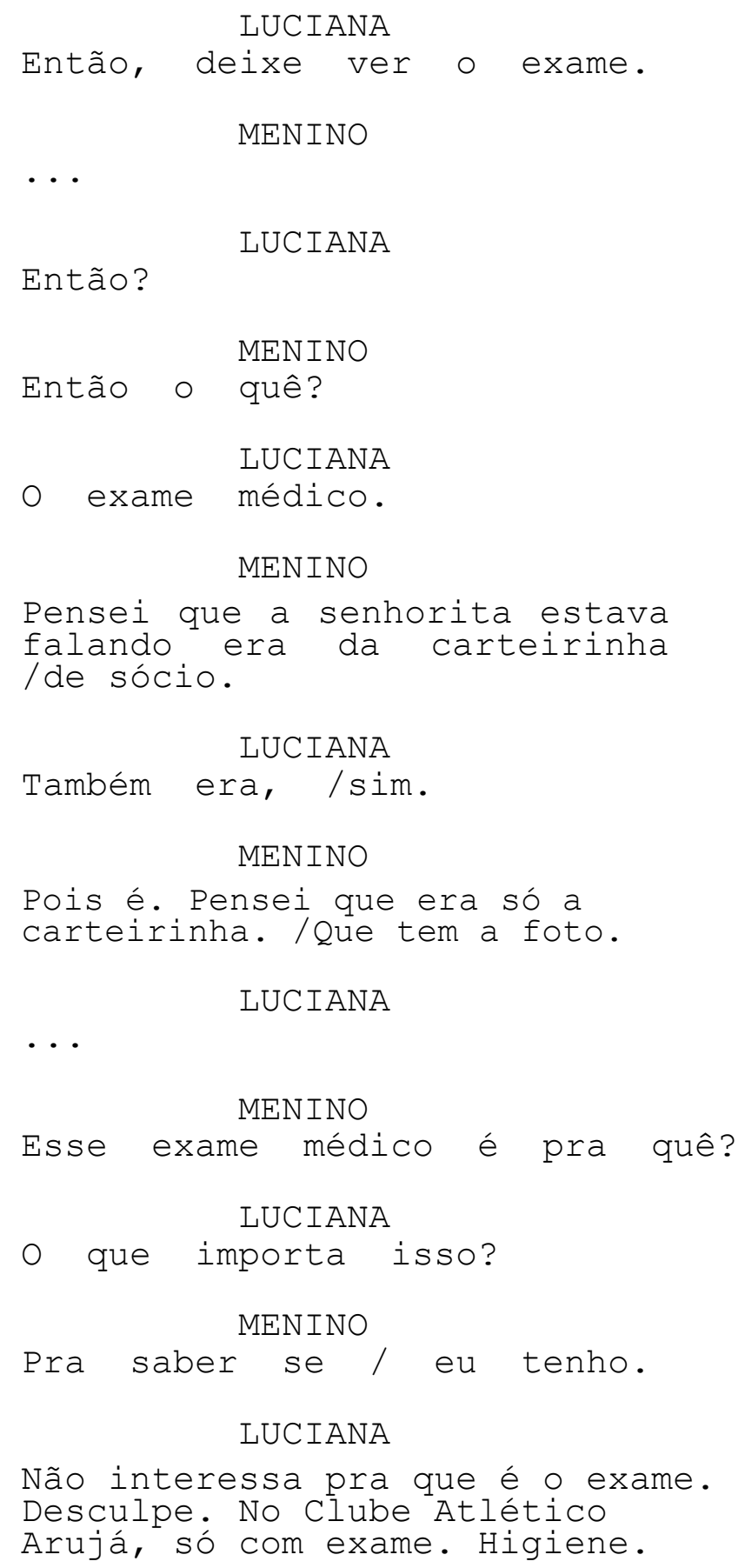




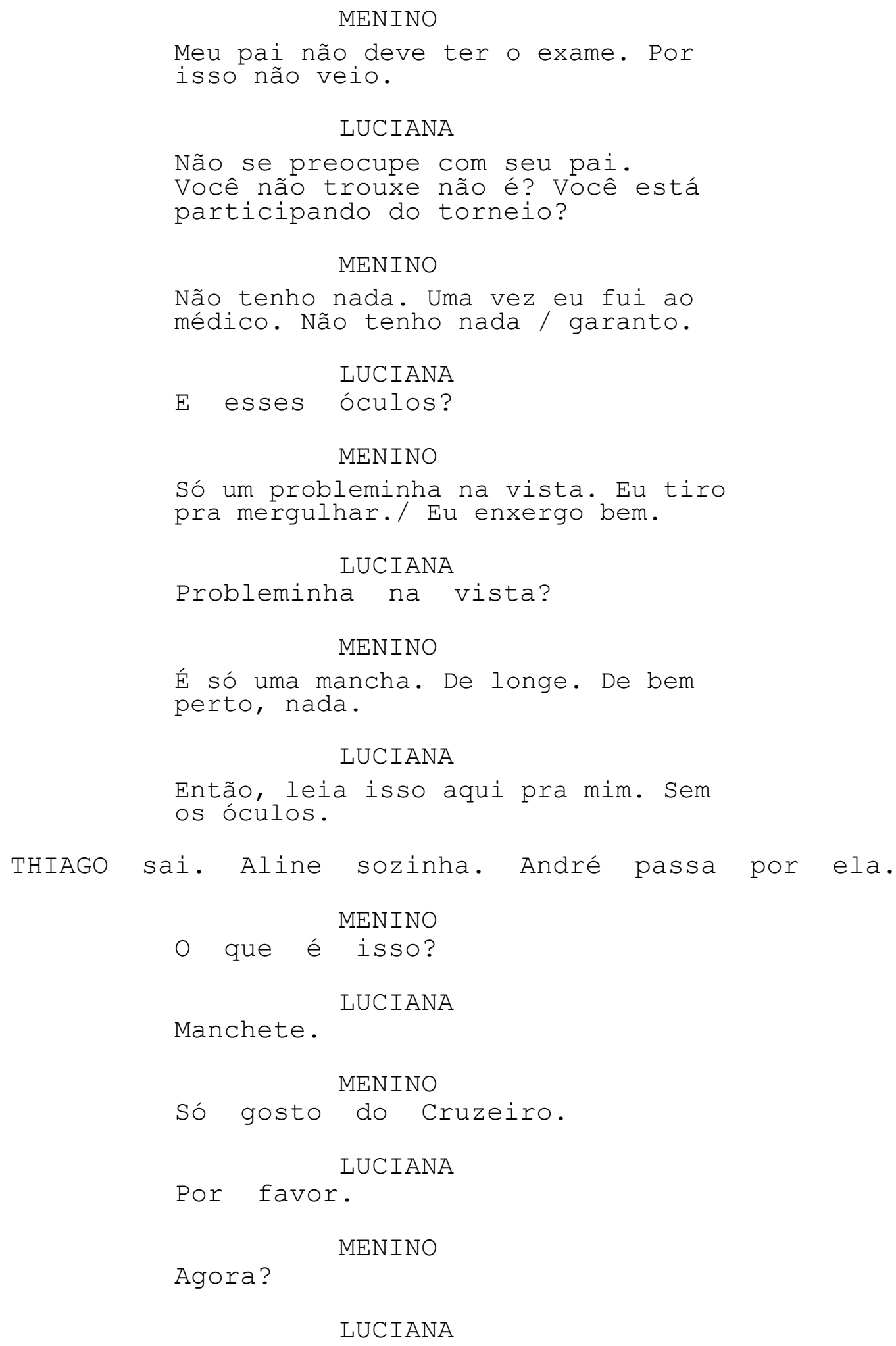




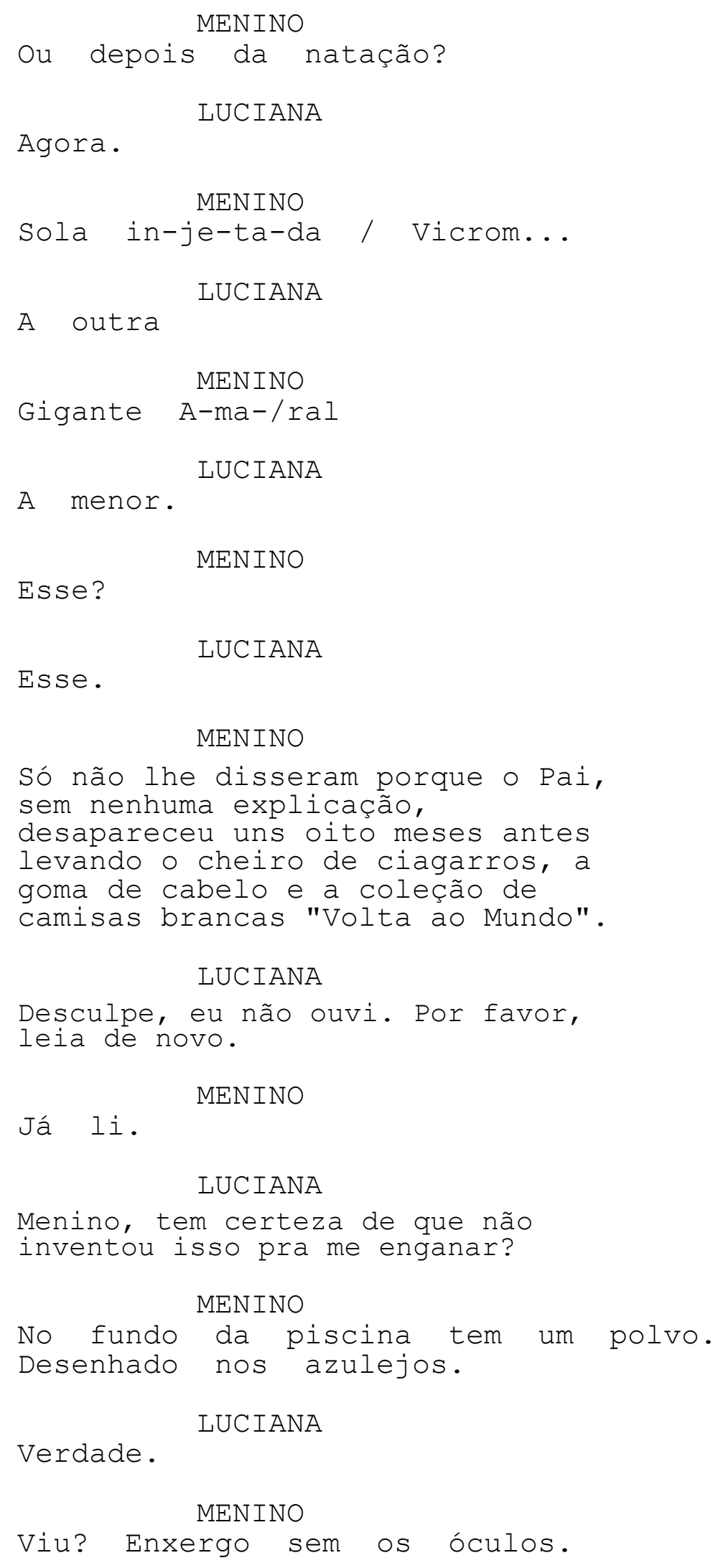




\title{
LUCIANA
}

Então, vá lá. Dessa vez passa. Mas antes (pausa) posso lhe contar uma coisa? Você se incomoda?

Ela começa a cochicar no seu ouvido. É interrompida pelo grito de PAULA.

\author{
PAULA \\ (com FLÁVIA em (F))
}

Luciana!

LUCIANA atravessa (A) e corre até (F), para se encontrar com PAULA e FLÁVIA. A pedido de PAULA, LUCIANA sai para o fundo. PAULA e FLÁVIA ocupam (A) .

o MENINO entra no Clube. Ele volta para (D). Senta-se no chão .

\section{A EQUiPE DE NATAÇ̃̃O}

Deslocamento temporal 01

MARIA AMÉLIA volta, repetindo as mesmas ações, em (B). O menino a observa.

\section{MENINO}

O Menino chega por volta das dez, dez e meia da manhã, quando há poucas pessoas presentes - em geral mulheres sozinhas da mesma idade de seu pai. Dona Maria!

Os dois estão em (B). Vemos MARIA AMÉLIA de frente, bem perto do MENINO, de costas. Ações idênticas a primeira vez em que vimos a cena. FERNANDA espera por MARIA AMÉLIA em (C-esq).

\section{MENINO}

Pode ver: passei tudo direitinho. Todas as cores de linha que a senhora pediu. Acabei agora.

\section{MARIA AMÉLIA}

Estou vendo. Você não mostrou pra ninguém, mostrou? Olha o que eu prometi.

\section{MENINO}

É difícil pra senhora enxergar o buraquinho, né? 
MARIA AMÉLIA

Você está indo pro Clube? Vai nadar hoje?

LUCIANA, em (A), abre o Clube Atlético Arujá.

MENINO

Pra mim também é difícil, mas eu

chego bem pertinho do rosto.

MARIA AMÉLIA

E O seu pai, não vem hoje ao clube?

MENINO

Eu vou mergulhar pra ver o polvo que o Pai falou que tem no fundo da piscina.

DANIELA aparece em (E), carregando seu aquário e uma bolsa. Ela coloca a bolsa no chão e prepara-se para falar no aquário. ALINE, em (A), entra no Clube, mostrando a carteirinha a LUCIANA.

MARIA AMÉLIA se aproxima do ouvido do MENINO e sussura algo que não ouvimos.

\section{MENINO}

De todos os efeitos do desquite, o único que continua a surpreender Maria Amélia é o fato de que os sinais de amor do que ficou pra trás - da outra vida - tivessem sobrevivido à catástrofe e continuassem vivendo em meio à nova vida mais ou menos ilesos. Era comum ela se descobrir mexendo na alianção que não está mais no seu dedo, ou ficando encolhidinha no mesmo canto antigo da cama, ou abrindo o armário pra sentir o cheiro das camisas e pregar os botões que faltaram. Não que ela sentisse falta do casamento: sempre que atrasava o almoço ou passava as tardes olhando as fotografias do James Dean, ela sentia aquele mesmo alívio dolorido de quando pingava gotinhas de limão nos olhos.

MARIA AMÉLIA se afasta, surpreendida pelo que acabou de dizer. 


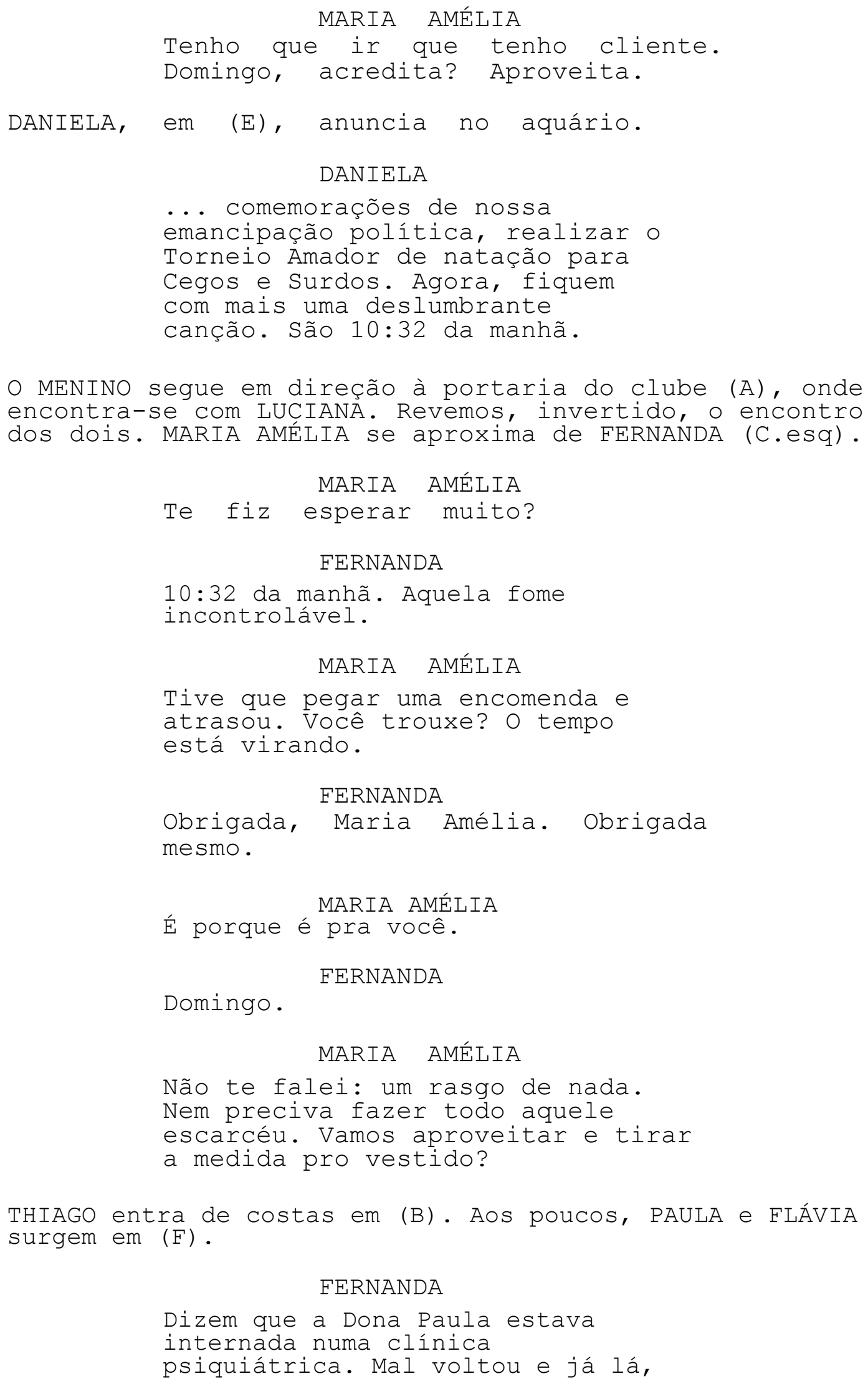

THIAGO entra de costas em (B). Aos poucos, PAULA e FLÁVIA surgem em $(F)$.

\section{FERNANDA}

Dizem que a Dona Paula estava

internada numa clínica psiquiátrica. Mal voltou e já lá, 
FERNANDA

toda solta. Dia de semana, com a irmã que tem problemas na frente de todo mundo. A piscina cheia de rapazes.

MARIA AMÉLIA

Vestida de banlon, aposto.

FERNANDA

Não é decente. É noiva. Mesmo com esses tempos modernos, marido não aguenta muito tempo e desquita.

MARIA AMÉLIA

$\cdots$

\section{FERNANDA}

Desculpe.

MARIA AMÉLIA

Imagina. Sentiu tanta raiva

que anotou: 101 de quadril.

FERNANDA

Um absurdo.

MARIA AMÉLIA
Pra ficar bem justo.
FERNANDA

A última mania dela é essa história de competição pra cegos. Por causa da irmã.

MARIA AMÉLIA

Por isso que no baile...

FERNANDA

Cheio de deficiente. Eu não sou contra, mas devia separar, ter dia específico. É melhor pra eles mesmos, pra não se sentirem diminuídos.

MARIA AMÉLIA
Eu não estou encontrando o
modelo que te falei, era assim
de buclê com manguinha de laise.

ALINE se aproxima de THIAGO em (B). Ambos de costas, olham a piscina. 


\section{FERNANDA}

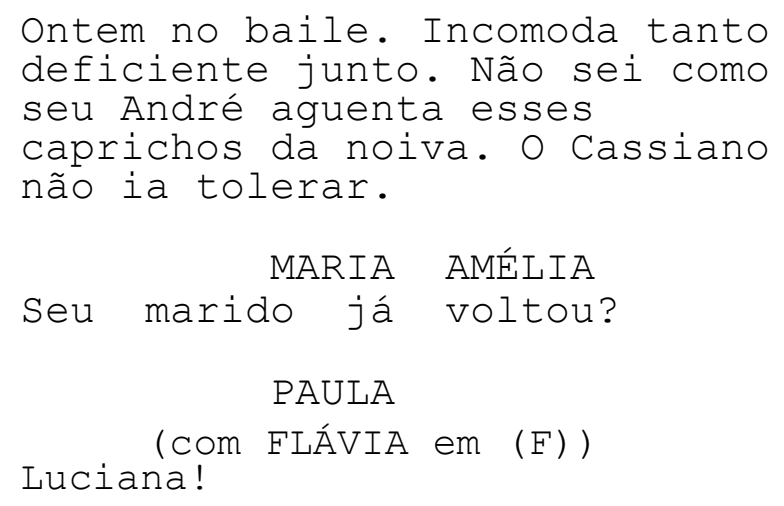

LUCIANA atravessa (A) e corre até (F), para se encontrar com PAULA e FLÁVIA. A pedido de PAULA, LUCIANA sai para o fundo. PAULA e FLÁVIA ocupam (A).

\section{FERNANDA}

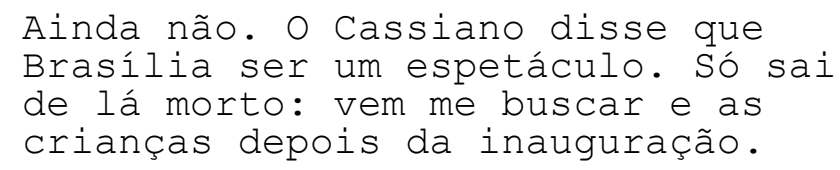

THIAGO sai.

\section{FERNANDA}

Todas as manhãs, Fernanda ficava chocada ao se lembrar de que vivia sozinha com os dois meninos. Saindo dali, ia direto a farmácia.

Me passa a Fon Fon, faz favor.

\section{FERNANDA}

Acho que essa história de clínica psiquiátrica deve ser verdade. Essa é a Fon Fon. Você se lembra daquela apresentação que ela fez, só de combinação? Não sei como o seu André não desmanchou o noivado. A mulher de respeito deve estar ciente que dificilmente um homem pode perdoar que ela não tenha resistido a experiências pré-nupciais. Mesmo que o homem consiga divertir-se com a namorada ou noiva, na verdade ele não vai gostar de ver que ela cedeu. 
ALINE fica sozinha em (B). DANIELA, sozinha em (E), apaga seu cigarro. Em (A), LUCIANA volta trazendo dois copos d'água e um doce e observa as duas irmãs. ANDRÉ passa por ALINE em (B). Os dois se cumprimentam. Ele atravessa a cena até (A) e desaparece. LUCIANA aparece em (E), de costas, cOM DANIELA.

\section{MARIA AMÉLIA}

Achei. Vamos fazer igual ao da Yoná Magalhães. É a Yoná Magalhães, não é? (pausa) É?

É.

FERNANDA

MARIA AMÉLIA

Lindo, não é? Olha, pouquinha coisa mais curto.

\section{FERNANDA}

Maria Amélia, está tudo bem? Com seu olho.

MARIA AMÉLIA

Está, claro. É só vista cansada, de ficar forçando. Preciso pedir pra colocarem uma lâmpada aqui.

\section{DANIELA}

(no aquário) ...como as rainhas do egito antigo (pausa), nuvens carregadas de açúcar (pausa) antes da grande tempestade (pausa) antes do seu doce beijo (pausa). Me beija, me beija, doce amor.

FERNANDA

Fernanda quis dizer que com 0 marido em Brasília era difícil até trocar uma lâmpada ou dar um corretivo nos meninos. Estava decidida: seringa, desinfetante, sabonete e água quente.

ALINE desaparece por (B). LUCIANA de costas, ao lado de DANIELA em (E).

MARIA AMÉLIA

Mas estou enxergando direitinho.

Seu vestido vai ficar uma jóia. 
FERNANDA

Acho que eu prefiro mais no estilo

das garotas do Alceu.

MARIA AMÉLIA

É que é preciso ter a cintura um pouquinho mais fina. Ou não fica bom.

\section{FERNANDA}

‥

\section{MARIA AMÉLIA}

Mas é só fazer uma compressinha com sumo de limão que melhora. O olho. Confia em mim. Eu já fui modelista até da Dona Darci Vargas.

FERNANDA

Você viu quem estava no baile ontem? Voltou. O retratista.

THIAGO vem de (B) e vai até o MENINO (C-esq). THIAGO se aproxima do MENINO, ele tem fotografias nas mãos. Antes de começar um diálogo, tira uma foto do MENINO.

\section{PALAVRAS FOTOGRAFADAS}

THIAGO parece conhecer o MENINO. Ele não fala: todo o texto em Libras.

MENINo
O menino retira os óculos com
cuidado e os deixa protegidos à
beira da piscina. Então já começa
a imaginar a boca aberta do polvo
pintado nos azulejos com os pés na
água gelada. Treina prender a
respiração, como o pai ensinou.

As duas irmãs, em (A), treinam prender a respiração. Antes de começar o diálogo, THIAGO tira uma foto do MENINO.

THIAGO
[lembra de mim?]
Eu ia mergulhar agora.
THiAgo
[você já está bem grande.]


MENINO

Não conseguiu deixar de pensar no rosto do pai, com os cabelos lambidos e os olhos fechados, cheios de cloro.

\section{THIAGO}

[olha, você me faz um favor?

leva essa fotografia pra moça do altofalante?]

\section{MENINO}

uma foto. levar pra moça dos avisos. (ele lê, com a foto bem perto do rosto). é segredo?

[é, é segredo]

THIAGO

\section{MENINO}

Mais um pra sua coleção de segredos.

THIAGO
[o que tem aí?]

\section{MENINO}

Ah, aqui... tem uma bola que eu ganhei pra passar linhas em agulhas. É difícil. Meu pai joga assim na piscina e ela faz assim. Você também sabe? Quer jogar?

Os dois começam a jogar. Em (A), Flávia e Paula recebem ANDRE. LUCIANA se despede de DANIELA em (E). DANIELA no aquário.

\section{DANIELA}

Atenção, às quatro horas da tarde, a piscina será isolada para que se dê início ao torneio de Cegos e Surdos.

Por que você não fala?

LUCIANA passa por eles (B). THIAGO fica conversando com ela em (B). O MENINO volta para (C.esq).

MENINO

Um dos poucos segredos que o menino nunca ouviu é porque o pai, desde que a mãe passou a dormir sozinha, 


\section{MENINO}

volta todos os domingos de manhã, para apertar o botão do interfone e pedir: "Desça de uma vez, vamos ao clube que hoje não chove", com aquele tom crispado que ele já reconhece como o emblema do estado que fica a relação dos homens com as mulheres depois de ter filhos com elas.

THIAGO sai. LUUCIANA vem andando em direção a (A). No mesmo momento, ANDRÉ empurra FLÁVIA (A), que esbarra em LUCIANA. O MENINO observa tudo. FLÁVIA vem em sua direção.

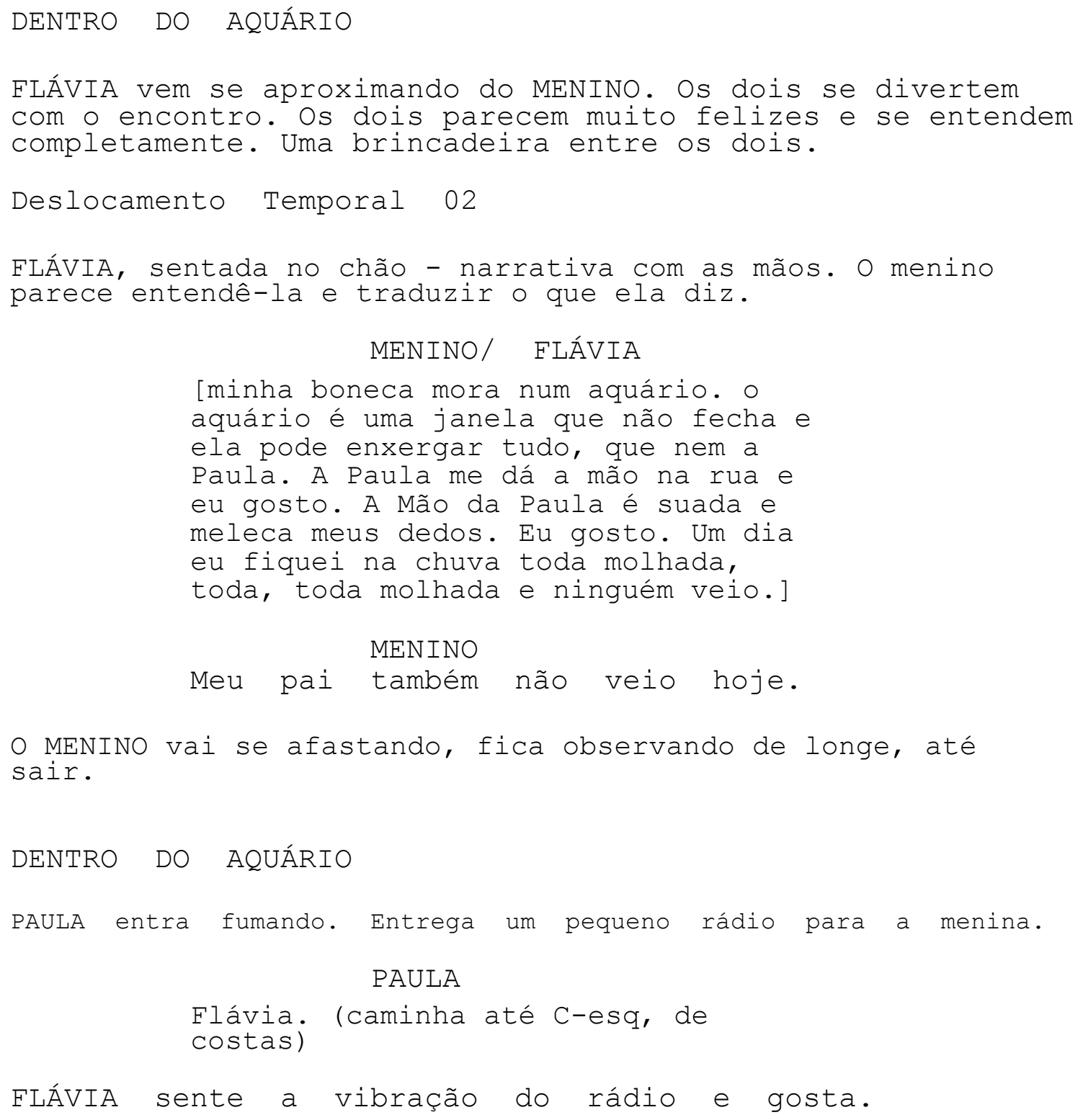




$$
\begin{aligned}
& \text { DANIELA (V.O) } \\
& \text { parrealizar o torneio de Natação } \\
& \text { para Cegos e Surdos. Agora, } \\
& \text { fiquem com mais uma deslumbrante } \\
& \text { canção. 10:32 da manhã. }
\end{aligned}
$$

PAULA retira o rádio da menina e tenta dar-lhe os óculos de natação. FLÁVIA se recusa, jogando os óculos no chão. (Algumas vezes)

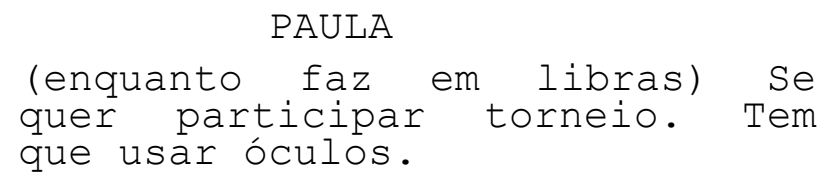

FLÁVIA joga os óculos longe.

PAULA

Luciana!

Vai até FLÁVIA. LUCIANA entra vindo de (A).

Água .

PAULA

LUCIANA sai. Otávio aparece em (E) : acaba de entrar no clube. Ele vai repetir toda a sua trajetória até o encontro com THIAGO ali (retirar os óculos, etc)

PAULA

(arrastando a irmã) Não óculos, não

torneio. Não óculos, não torneio.

As duas se sentam. Finalmente FLÁVIA coloca os óculos. LUCIANA volta de (A). Ela traz um copo d'água.

$$
\begin{aligned}
& \text { PAULA } \\
& \text { Dois copos d'água e alguma coisa } \\
& \text { pra ela comer. }
\end{aligned}
$$

LUCIANA sai. PAULA e a irmã se acalmam. As duas irmãs começam uma espécie de treinamento. A comunicação das duas acontece em libras, ou em gestos muito particulares.

\section{FLÁVIA}

[quanto tempo até torneio?]

\section{PAULA}

Faltam umas duas horas. Dois. Dá tempo de treinar muito mais. Quer?

LUCIANA entra com os dois copos d'água e um doce. Eu tenho certeza de que você vai vencer. $\mathrm{C}-\mathrm{A}-\mathrm{M}-\mathrm{P}-\mathrm{E}-\mathrm{A}$. 


$$
\begin{gathered}
\text { FLÁVIA } \\
\text { [eu viver P-E-I-X-E igual thiago] } \\
\text { PAULA }
\end{gathered}
$$

Pode deixar aí, Luciana. É só isso.

LUCIANA sai. FERNANDA surge em (A). Em seguida, MARIA AMÉLIA também chega e as duas repetem o encontro inicial.

PAULA
Tomara que não chova. S-O-N-H-O.
FLÁVIA está comendo. Ela escuta PAULA (tadoma).
PAULA

Eu meu noivo você a beira da piscina.

[noivo?]

FLÁVIA

PAULA

(mostra a aliança) N-O-I-V-O. Você correndo para mim. centenas de gotinhas no seu maiô florido. sol nos olhos abertos, gritando:

"água gelada". Longe, tirando fotos, ele me esperava.

[o noivo?]

$$
\text { FLÁVIA }
$$

\section{PAULA}

Não o noivo. O Thiago. as malas prontas. um carro. vento no rosto. você longe. aquela sensação de quando você vai se afastando das pessoas e elas vão diminuindo. Se dissolvendo. eu chegava bem perto dele, pra ter certeza de que ele tinha voltado. Tive.

\section{A EQUIPE DE NATAÇÃO}

MARIA AMÉLIA e FERNANDA saem de (A) e vão até C-esq. PAULA e FLÁVIA continuam em C-dir. OTÁVIO continua em (E).

FERNANDA

Você viu quem estava no baile ontem? Voltou. O retratista.

THIAGO entra em (E) e conversa com OTÁVIO. 


\section{MARIA AMÉLIA}

Voltou mesmo. Eu acho que o vi no clube ontem.

ANDRÉ entra em (A) e fica ensaiando seu discurso.

FERANANDA

Voltou. Seu André não devia deixar

- retratista voltar a frequentar o

Clube, é má influência pra noiva

dele. As pessoas não se esqueceram

daquela indecência que ele e a

Dona Paula fizeram ano passado.

MARIA AMÉLIA

As pessoas falam demais.

FERNANDA

Você não se chateia se eu comentar uma coisa?

MARIA AMÉLIA

Ela se perguntou se Fernanda era assim sem assunto porque ninguém lhe dava atenção ou se ninguém

lhe dava atenção porque ela era assim sem assunto.

FERNANDA

Arujá inteira está comentando. Do desquite.

MARIA AMÉLIA

A boca de Maria Amélia estava semiaberta.

FERNANDA

Eles estavam comentando da sua calça: disseram que você estava vestida como homem.

MARIA AMÉLIA

Desculpe. É só uma ardência

no olho. Não dormi direito.

FERNANDA

Eu não fico irritando o Cassiano com ciúmes e dúvidas. Se uma mulher desconfiar da infidelidade do marido, ela deve redobrar seu carinho e provas de afeto. 


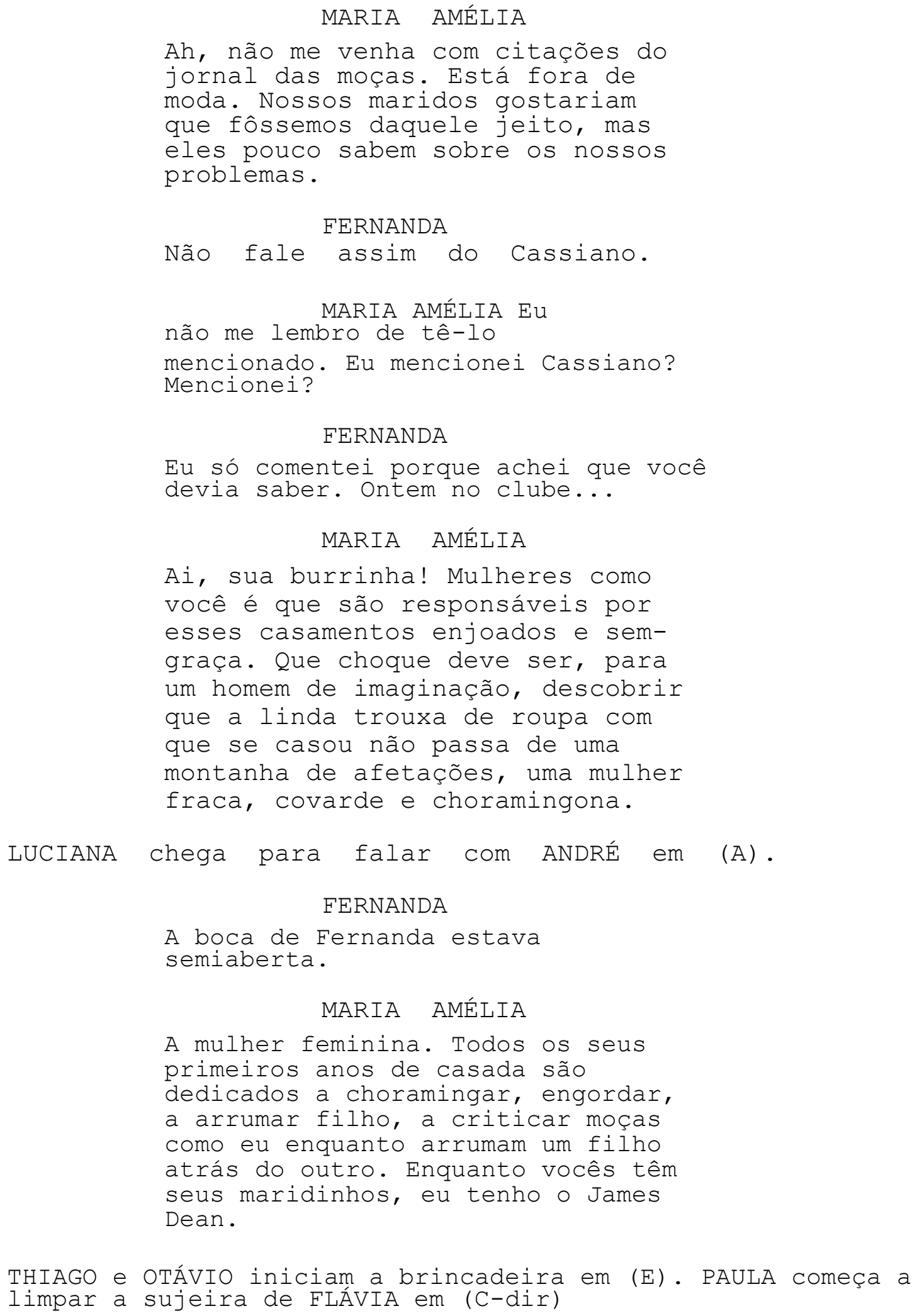

THIAGO e OTÁVIO iniciam a brincadeira em (E). PAULA começa a limpar a sujeira de FLÁVIA em (C-dir) 


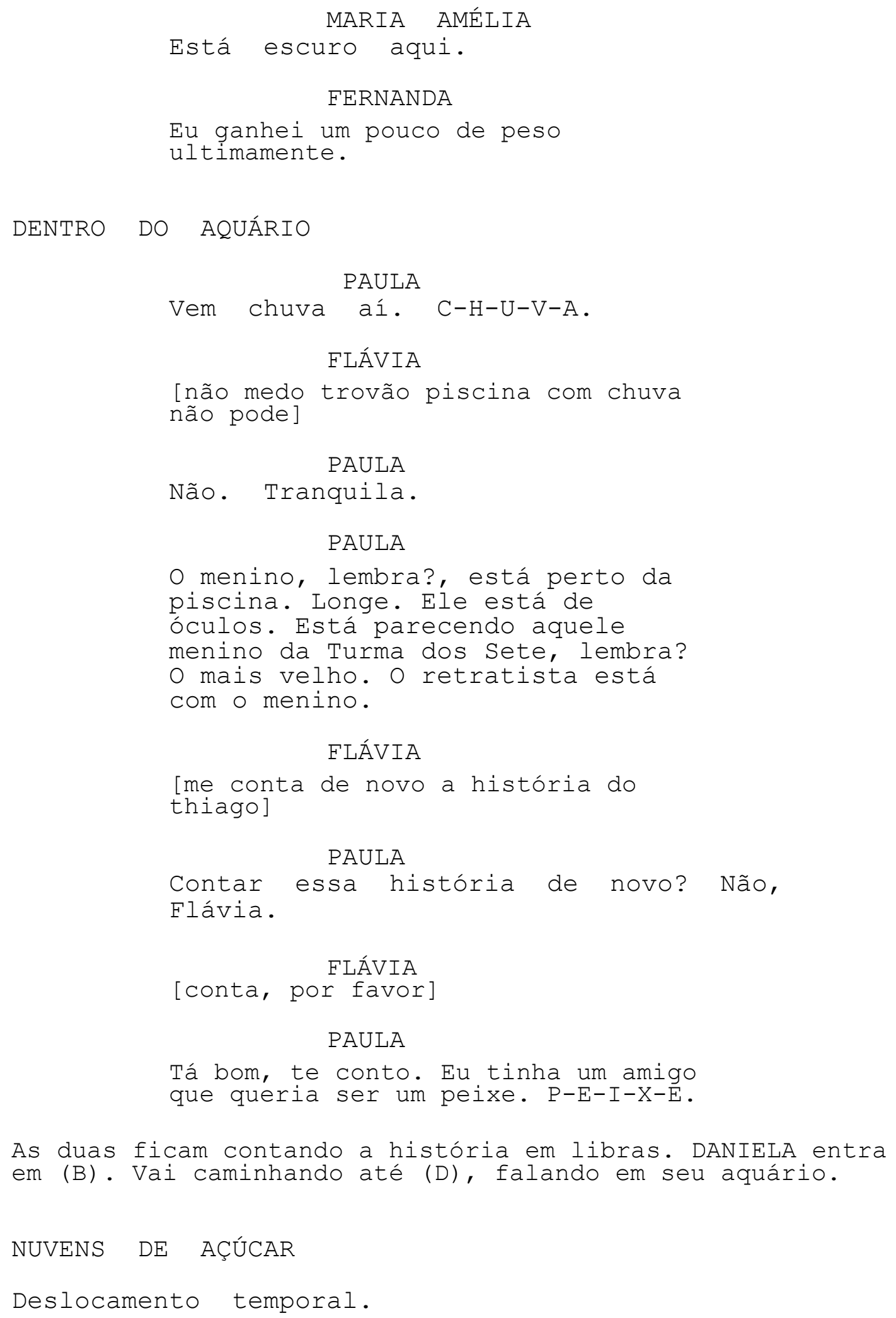


DANIELA

Bom dia, sócios e frequentadores do Clube Atlético Arujá. Hoje, 19 de fevereiro de 1959 - data histórica para nossa querida comarca, temos o prazer de, como parte das comemorações por nossa emancipação política, realizar o Torneio Amador de Natação para Cegos e Surdos.

Agora, fiquem com mais uma deslumbrante canção. 10:32.

O MENINO se aproxima dela. Ela não percebe.

DANIELA

Daniela repassa mentalmente as recomendações da tia: que era preciso se manter de pé, orgulhosa, de braços abertos, por causa da acolhida e pra não amassar a roupa. Desejar felicidades pra ele no primeiro esbarrão, no primeiro piscar de olhos, assim que se tocassem. Que era preciso manter os olhos abertos, olhando na direção da voz, para que ninguém desconfiasse de nada. Ela não vai ousar nem se sentar, em nenhum lugar. Ela imagina - desenho da roupa, as pregas no lugar certo, sopra os pingos de chuva que devem ter caído no caminho até ali para que eles sequem mais rápido e fica seca e novinha: novinha em folha. ̀̀ espera.

THIAGo escuta o altofalante em (A). MENINO

A senhora é a moça dos avisos?

DANIELA

Sim, sou. Quem é?

MENINO

Eu trouxe um bilhete pra senhora. Senhorita.

DANIELA

Um bilhete? De quem? 
MENINO

O menino sempre veste o calção

debaixo da calça, segundo um hábito

adquirido por conta própria e que

mantém a qualquer custo, mesmo com o desconforto que faz daquela conversa um verdadeiro calvário. Eu tenho que ir, que eu vou mergulhar.

\section{DANIELA}

Espera, posso te pedir uma coisa: pede pra ele vir aqui, pessoalmente. Diz que estou esperando.

O MENINO sai. ALINE chega perto de THIAGO em (A). Acabamos de ouvir mais uma

fascinante canção. E não se esqueçam, como parte das comemorações pela emancipação de Arujá, o Clube Atlético promoverá - concurso A Voz de Arujá. As inscrições poderão ser feitas na secretaria até as três da tarde.

LUCIANA entra na ponta dos pés. Faz um barulho com uma pequena garrafa de vermute.

Luciana?

DANIELA

LUCIANA

Nossa, Daniela, eu não sei como você aguenta essas modernidades...

DANIELA

É O meu preferido. Mirafiore, não é?

LUCIANA

Caixas acústicas.

DANIELA

Tente não se assustar com toda essa tecnologia. Parece complicado, mas o homem que a criou a fez simples o bastante para até o mulher poder usá-la.

LUCIANA

Trouxe as fotografias de hoje. 
DANIELA

Achei que ele vem pessoalmente. Ele te entregou?

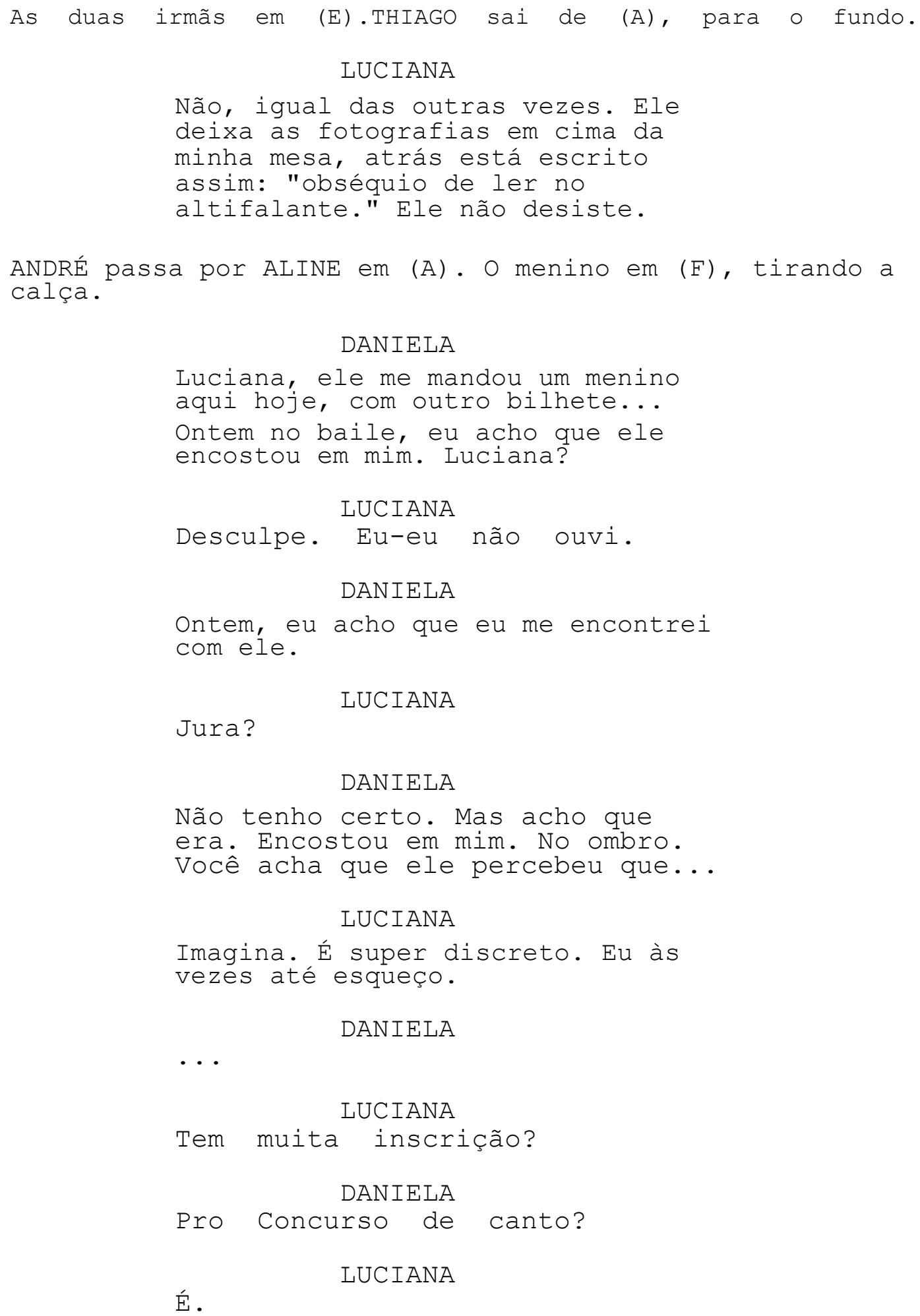




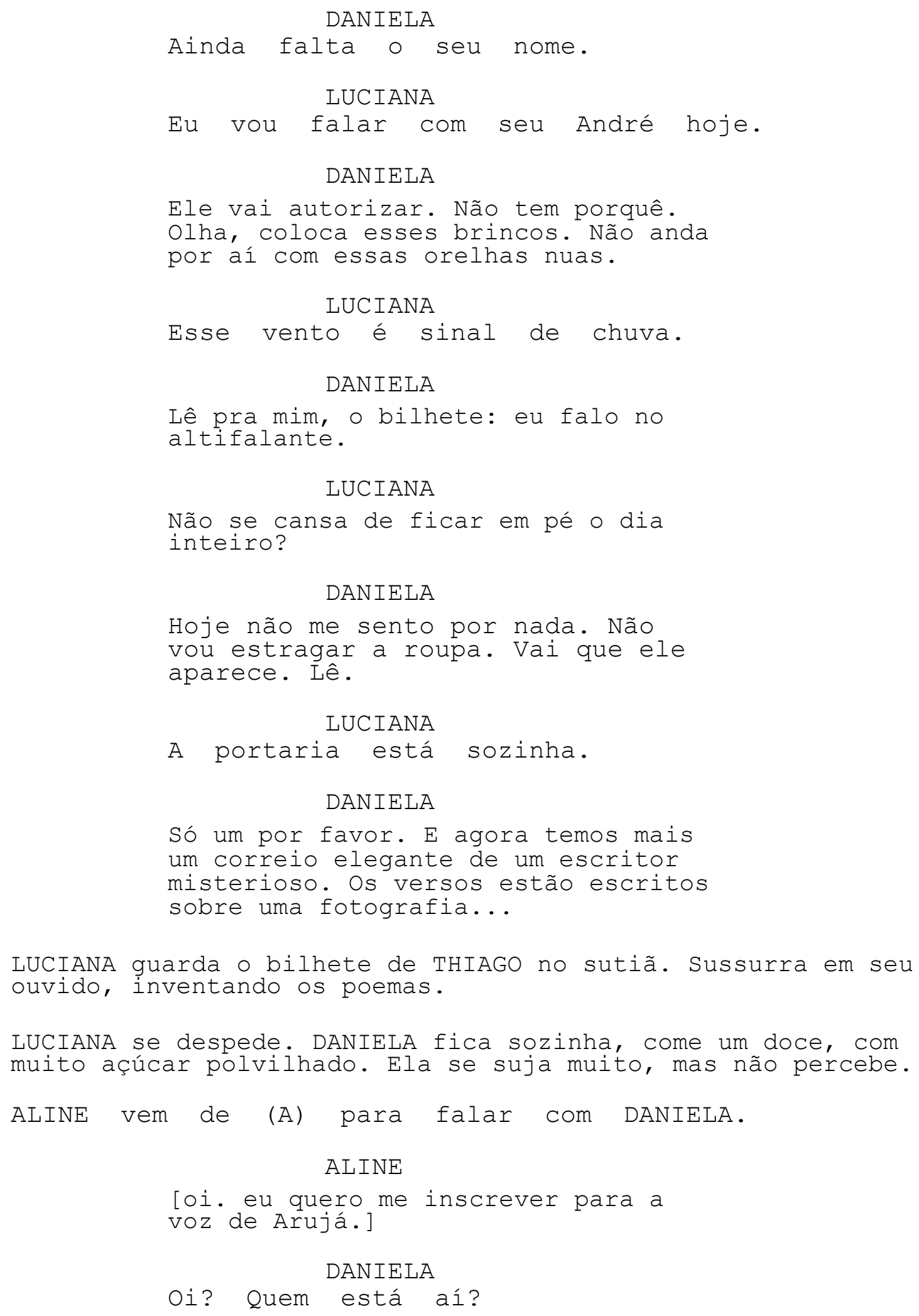


ALINE

[eu te liguei, você nem me escutou. eu quero me inscrever pra voz de arujá. me inscreveram nesse torneio, mas eu não sou cega nem surda. eu sou uma cantora.]

DANIELA

Fala direito mocinha, ou não te entendo.

ALINE

[eu vim me inscrever na Voz de Arujá ]

DANIELA

Voz de Arujá? Qual é o seu nome?

[aline]

ALINE

DANIELA

Janine.

ALINE

[aline ]

DANIELA

Então, Janine, vou tentar...

[aline. aline]

ALINE

EXPERIMENTAÇÕES AQUÁTICAS

Deslocamento temporal

\section{ALINE}

[é tanta inquietude. É tão esmagador o abatimento que a invade que ela passa as tardes olhando a piscina, os braços soltos. só o que a incomoda são as formigas. E ali aline brilha como ninguém ali ela encontra um lugar: como se estivesse debaixo d'água.]

ALINE se aproxima de THIAGO, que está ouvindo o altofalante em (C-esq-fundo). O MENINO está em (E), repetindo sua trajetória. 
ALINE

[você se incomoda? ficar aqui? Hoje não tem aula de experimentos. Mas eu resolvi vir do mesmo jeito. eu gosto de ficar olhando a piscina.]

THIAGO

[eu também. Gosto muito]

[bonito, né?]

ALINE

THIAGO

[eu gostei muito do baile ontem. De dançar com você.]

ALINE

[gostei. baile. o baile de ontem. dançar. com você. Eu fiquei feliz por você ter voltado.]

THIAGO

[você dança bem]

ALINE

[eu. Dançar bem. Obrigada. Você também. Eu estava te esperando.]

THIAGO

[me deu vontade de dançar com rostinho colado]

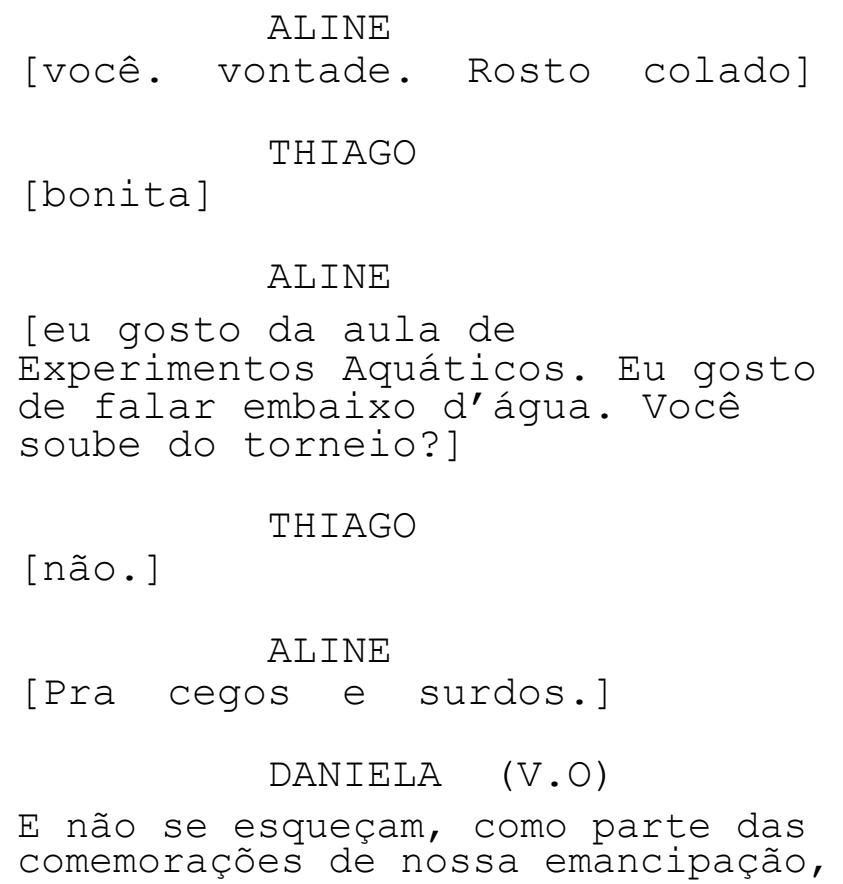


DANIELA

(V.O) comemoraremos A

Voz de Arujá...(cont)

ALINE

[deve ser bonita a moça que dá

avisos no altofalante.]

Thiago a interrompe. Quer ouvir o anúncio.

THIAGO

[eu pedi, mas não lêem minhas

fotografias]

ALINE

[você. pediu. mas. não. ler. suas

fotografias. Você escreve para

que leiam no altifalante?]

[não ]

THIAGO

ALINE

[o torneio. queriam que eu participasse, mas eu não vou. não sou cega nem surda. Acho bonito o jeito de escrever desse escritor misterioso. Bonito assim, declarações nas caixas acústicas.]

$\begin{array}{ll}\text { THIAGO } & \\ \text { [eu vou tirar uma foto }]\end{array}$

$[a h$, tá bom.]

ALINE

ALINE se prepara para a foto. THIAGO tira do menino na piscina. LUCIANA passa vem de (B) e passa por (A) e vai até (F) . Thiago sai. ALINE o acompanha até (A). Fica sozinha (A), com seu aquário. O MENINO a olha.

MARIA AMÉLIA e FERNANDA entram em (B).

A EQUiPE DE NATAÇ̃̃O

FERNANDA

Não precisa ter dó de mim. MARIA AMÉLIA

Eu não tenho. 
FERNANDA

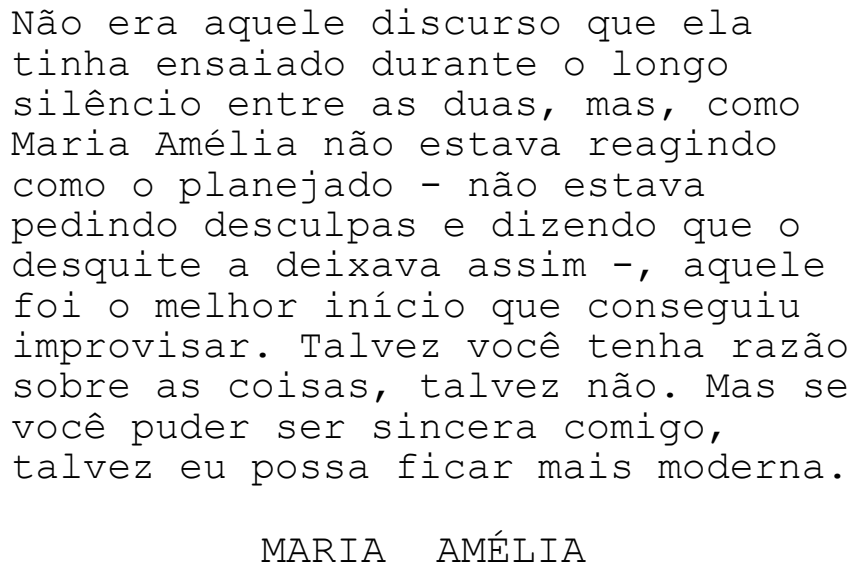

FERNANDA

Eu fiquei furiosa com você na semana passada, quando você tentou insinuar que aquele vestido não ficava bem em mim. Você acha que eu não sei me vestir? 


\section{MARIA AMÉLIA}

Acho.

FERNANDA

O que?

\section{MARIA AMÉLIA}

Não tentei insinuar nada. Se bem me lembro, eu disse que era melhor usar o vestido certo três vezes seguidas do que alterná-lo com vestidos horrorosos.

FERNANDA

E você acha isso uma coisa amável pra se dizer.

Eu não estavia tentando ser amável.
FERNANDA
Er..

\section{MARIA AMÉLIA}

Maria Amélia esperou até que a chuva de palavras gaguejadas se reduzisse a pequenas fungadelas.

FERNANDA

Se você me disser a verdade, eu vou escutar.

MARIA AMÉLIA Primeiro, você é toda esquisita. Por quê? Porque você nunca está segura sobre sua aparência. Quando uma mulher sabe que está bem vestida e penteada, já pode esquecer esses tópicos. É O chamado charme. Quanto mais partes de si mesma você esquecer, mais charmosa fica.

FERNANDA
Não estou bem como estou?
MARIA AMÉLIA.

Não. Não, por exemplo: você não cuida das suas sobrancelhas. Elas são pretas e brilhantes, mas desgrenhadas, um horror. Seriam bonitas se você cuidasse delas por um décimo de tempo que gasta fazendo nada. 
FERNANDA

Fernanda levantou as sobrancelhas em questão.

MARIA AMÉLIA

Você devia escová-las, para que elas cresçam alinhadas.

\section{FERNANDA}

Você está querendo dizer que homem repara em sobrancelha? Duvido que você possa enxergá-las.

\section{MARIA AMÉLIA}

Está vendo, já está ficando bravo. É só cansaço na vista.

ALINE, em (A), dentro de um aquário.

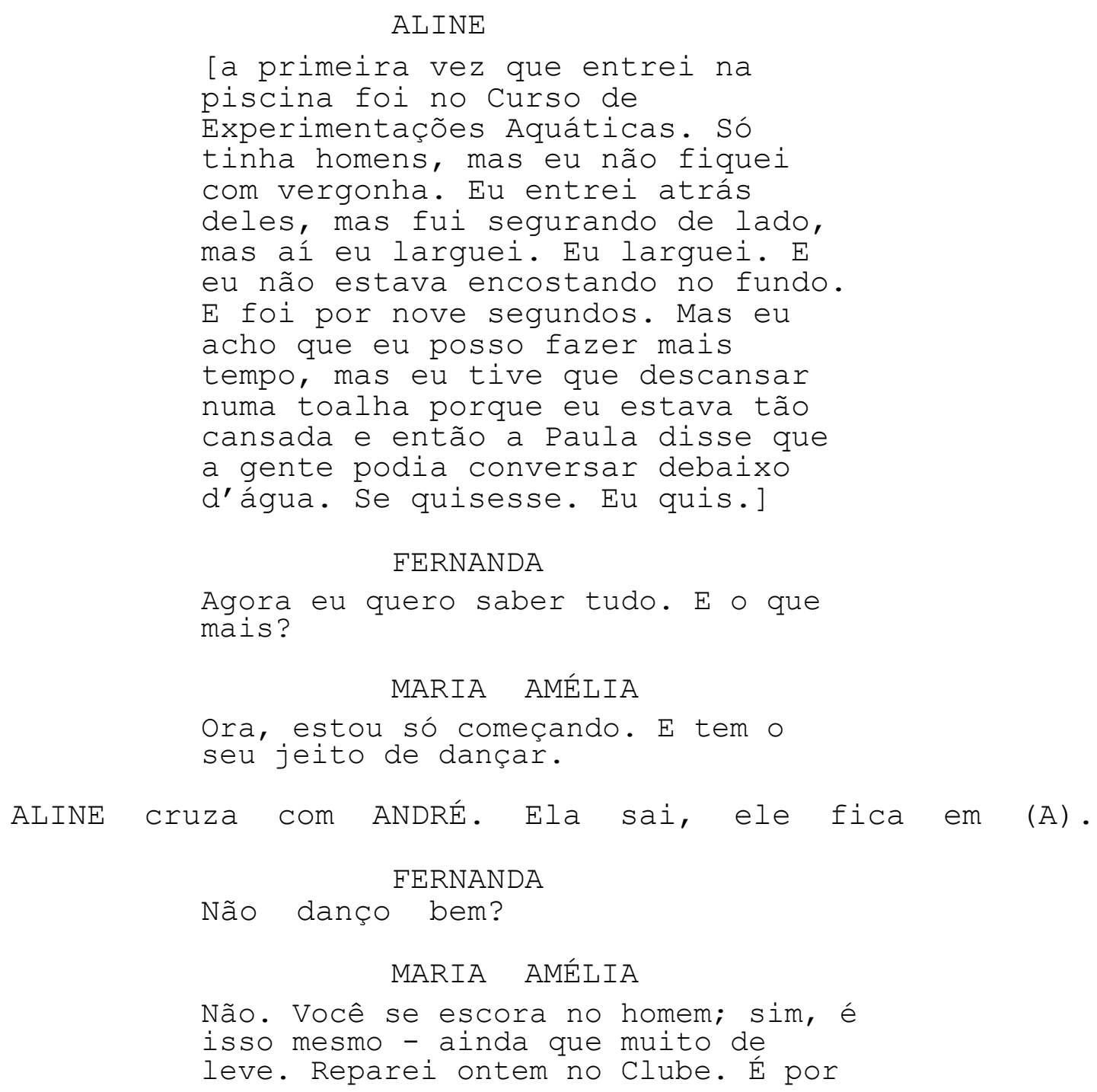

ALINE cruza com ANDRÉ. Ela sai, ele fica em (A).

$$
\text { FERNANDA }
$$

Não danço bem?

\section{MARIA AMÉLIA}

Não. Você se escora no homem; sim, é isso mesmo - ainda que muito de

leve. Reparei ontem no Clube. É por 


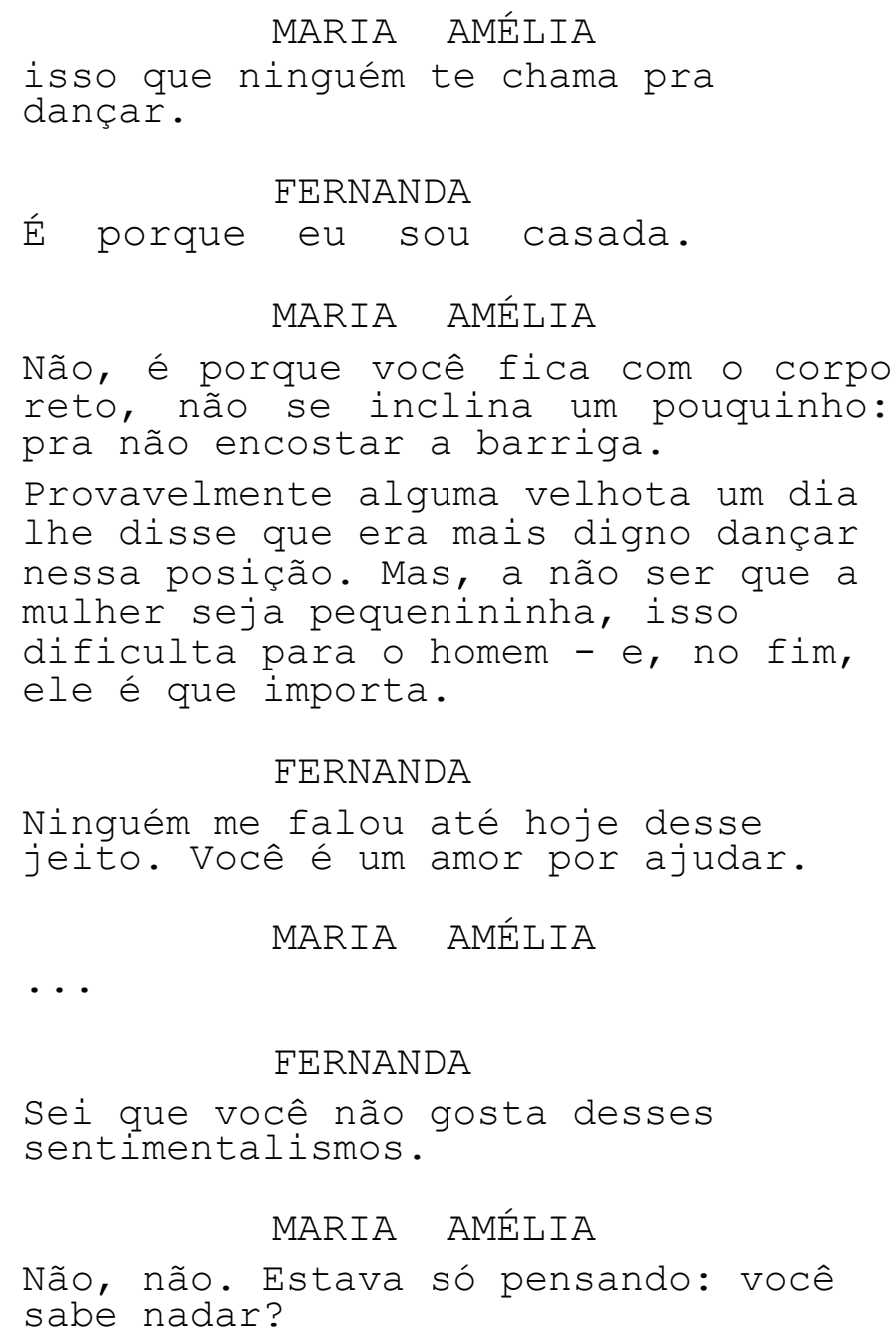




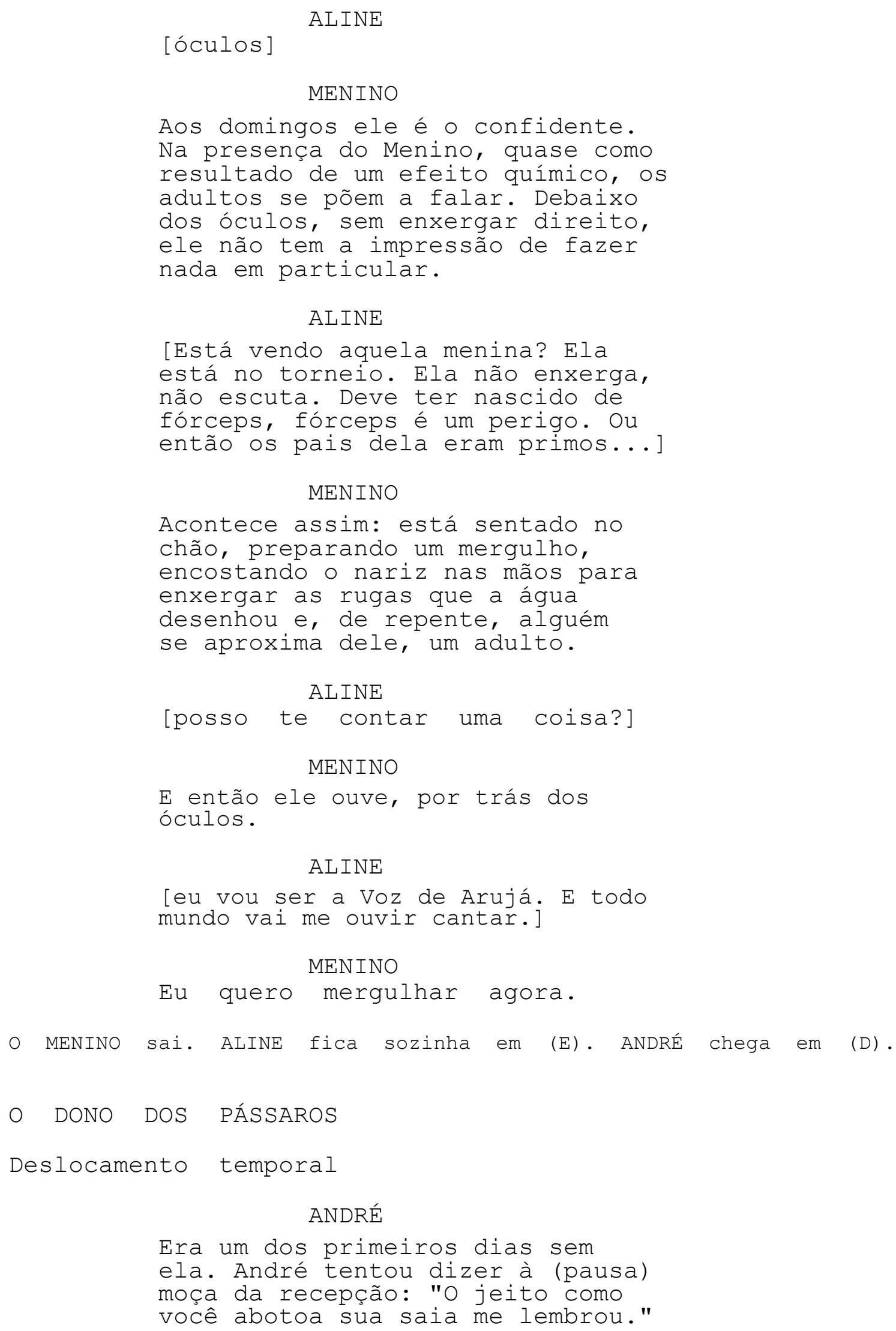




\section{ANDRÉ}

(pausa). Não conseguiu terminar a

frase, o nome dela não vinha. Tentou

mais uma vez. Não vinha, a palavra

presa dentro dele. Escreveu o nome

dela num guardanapo. Pra não

esquecer. (pausa) Queria as coisas,

gostava das coisas, mas não

conseguia dizer o zanto queria.

gostava dela.

\section{DANIELA (V.O)}

... de nuvens cheias de açúcar. Me beija, me beija, meu doce amor.

PAULA e FLÁVIA em (E), história do peixe. MENINO em (F), observa.

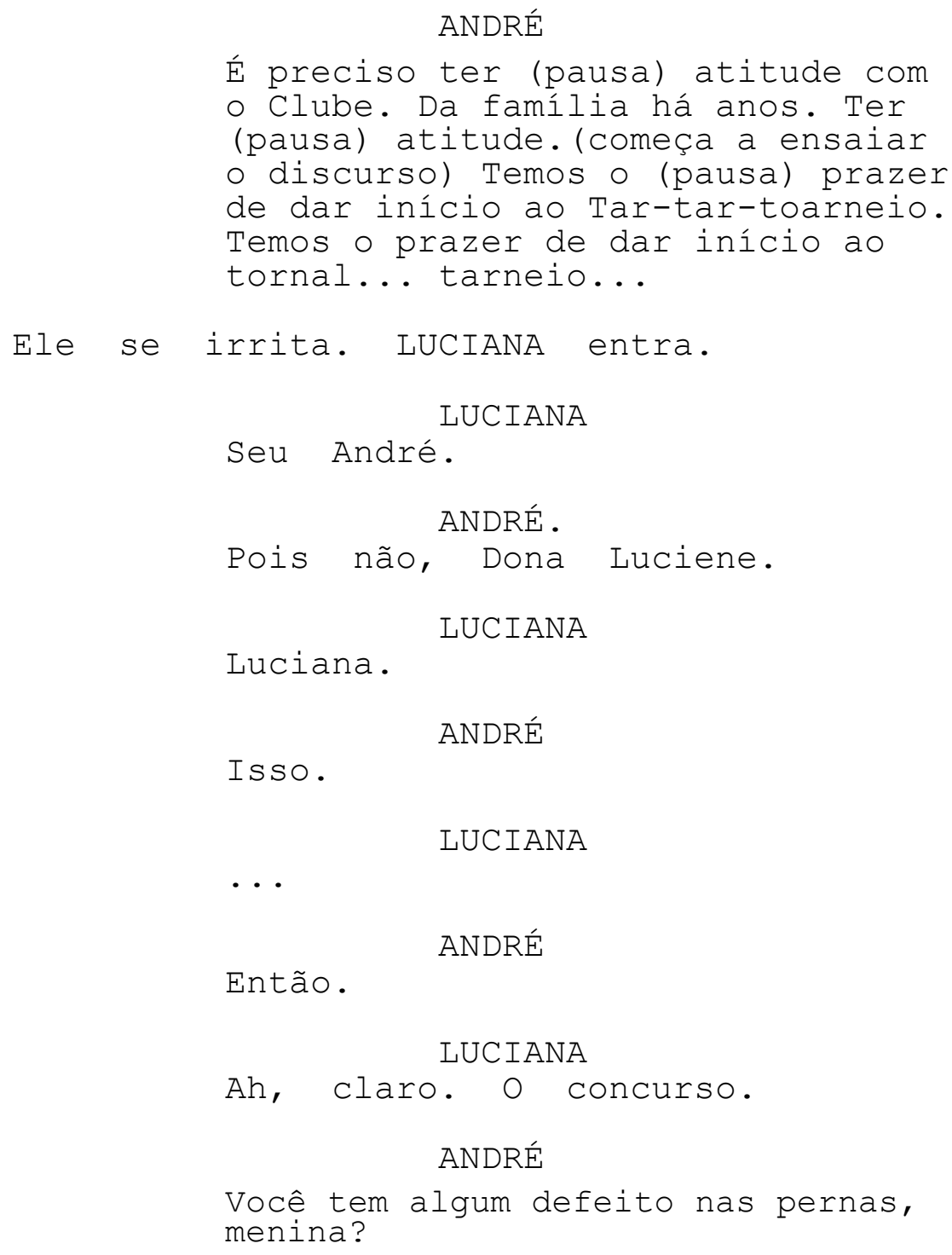

Ele se irrita. LUCIANA entra.

LUCIANA

Seu André.

ANDRÉ .

Pois não, Dona Luciene.

$$
\text { LUCIANA }
$$

Luciana.

$$
\text { ANDRÉ }
$$

Isso.

LUCIANA

$\cdots$

Então.

$$
\text { ANDRÉ }
$$

LUCIANA

Ah, claro. O concurso.

ANDRÉ

Você tem algum defeito nas pernas, menina? 


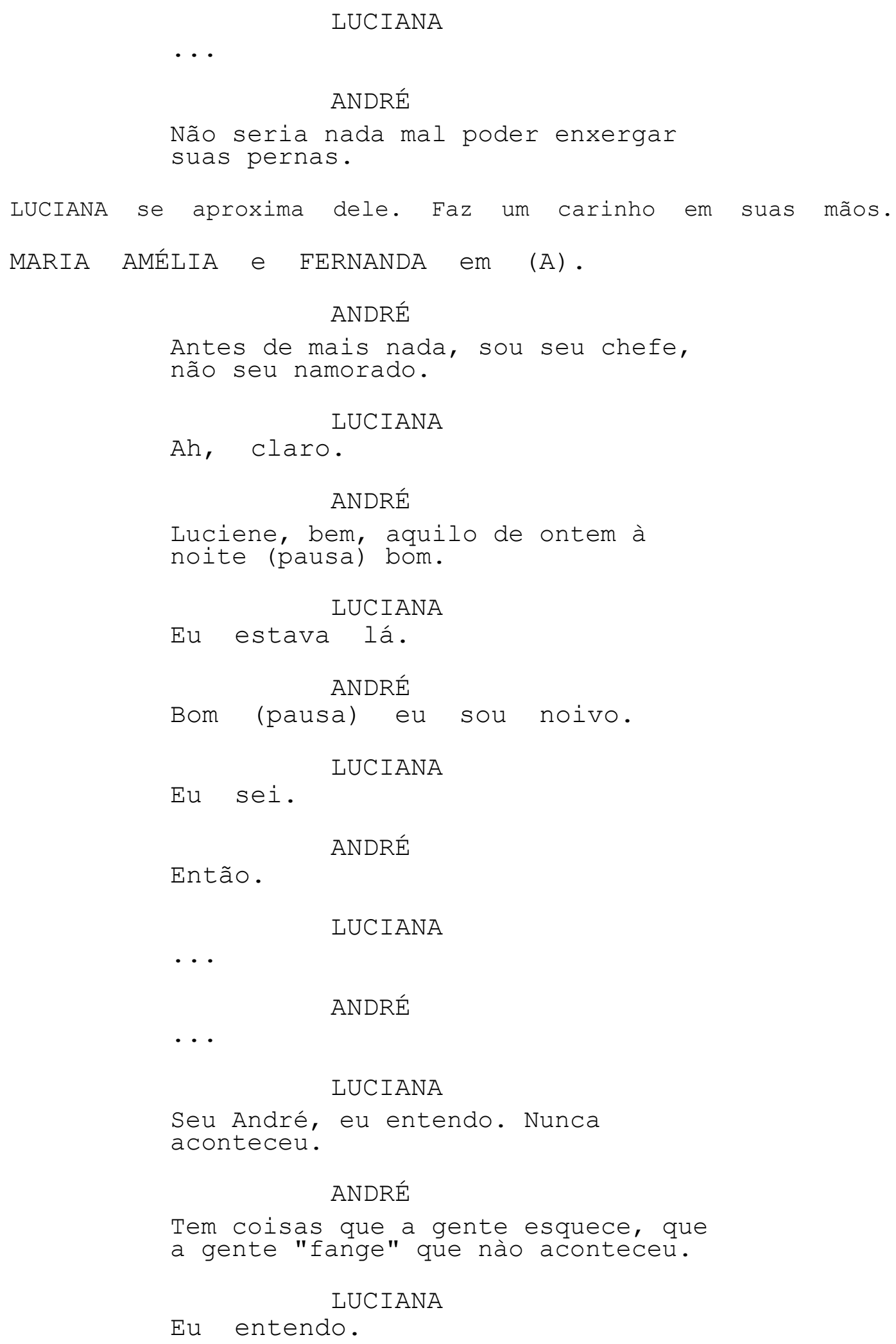

\section{LUCIANA}




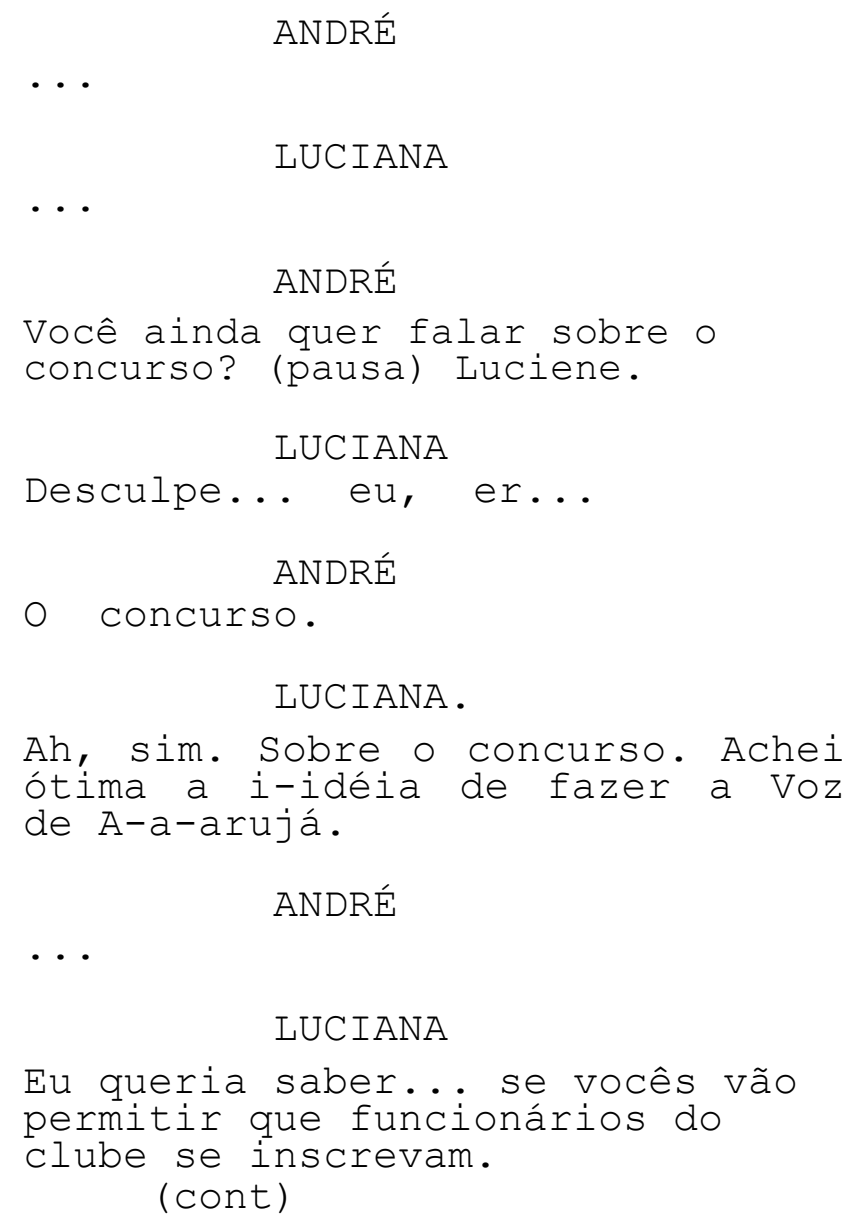


FERNANDA

Eu ficaria apavorada se tivesse que prender a respiração, porque um tio do Cassiano morreu porque prendeu a respiração por tempo demais num concurso de Prenda-a-respiração.

MARIA AMÉLIA

Ela pensou em perguntar se Fernanda acreditava em todas as histórias do Cassiano.

FERNANDA.

Eu acredito no Cassiano.Não se deve duvidar do marido.

\section{MARIA AMÉLIA}

Então as duas ficaram ali de pé em silêncio por um instante. Eu esperava que aquilo continuasse, e continou.

FERNANDA
Então você já nadou.
MARIA AMÉLIA

Maria Amélia contou a ela que esteve numa equipe de natação no Colégio de Moças e que chegou a participar do Campeonato Estadual, mas que foi logo derrotada por uma tal da escola católica.

\section{FERNANDA}

Fernanda parecia muito interessada na história.

\section{MARIA AMÉLIA}

Ela nunca tinha pensado naquilo como uma história, mas agora sabia que era uma história muito emocionante, cheia de drama e cloro.

\section{FERNANDA}

É mesmo muita sorte ter uma modelista que já foi professora de natação.

$$
\text { MARIA AMÉLIA Ela }
$$

não tinha dito que era

professora de natação, mas entendeu o que ela quis dizer.

$$
\text { (cont.) }
$$


O DONO DOS PASSAROS

(cont)

$\begin{array}{lc}\text { Eu entendo. } & \text { LUCIANA } \\ \text { Era só isso? } & \text { ANDRÉ } \\ \text { Sim. } & \text { LUCIANA } \\ & \text { ANDRÉ } \\ \text { Sabe onde ela está? }\end{array}$

(A)

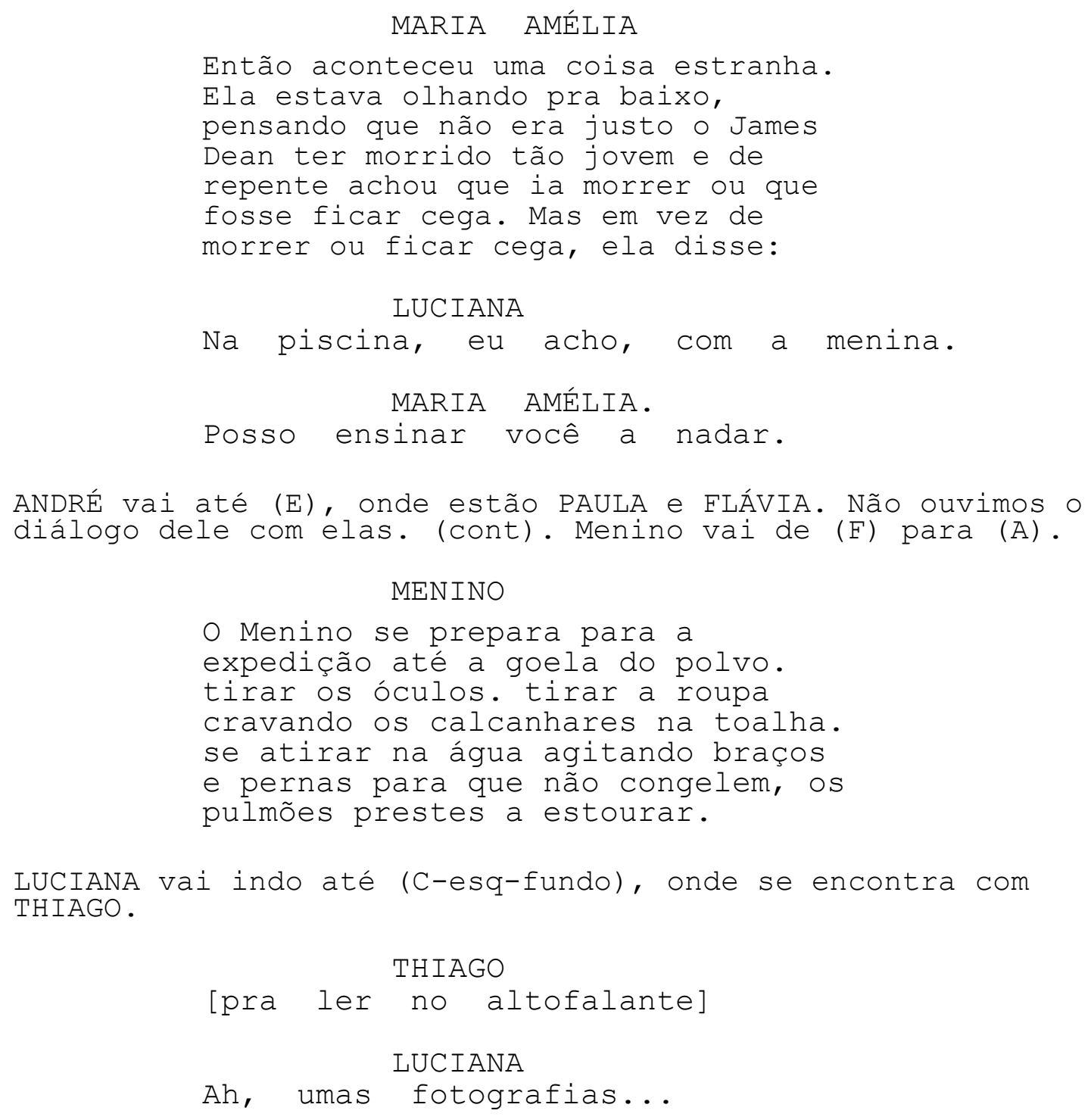




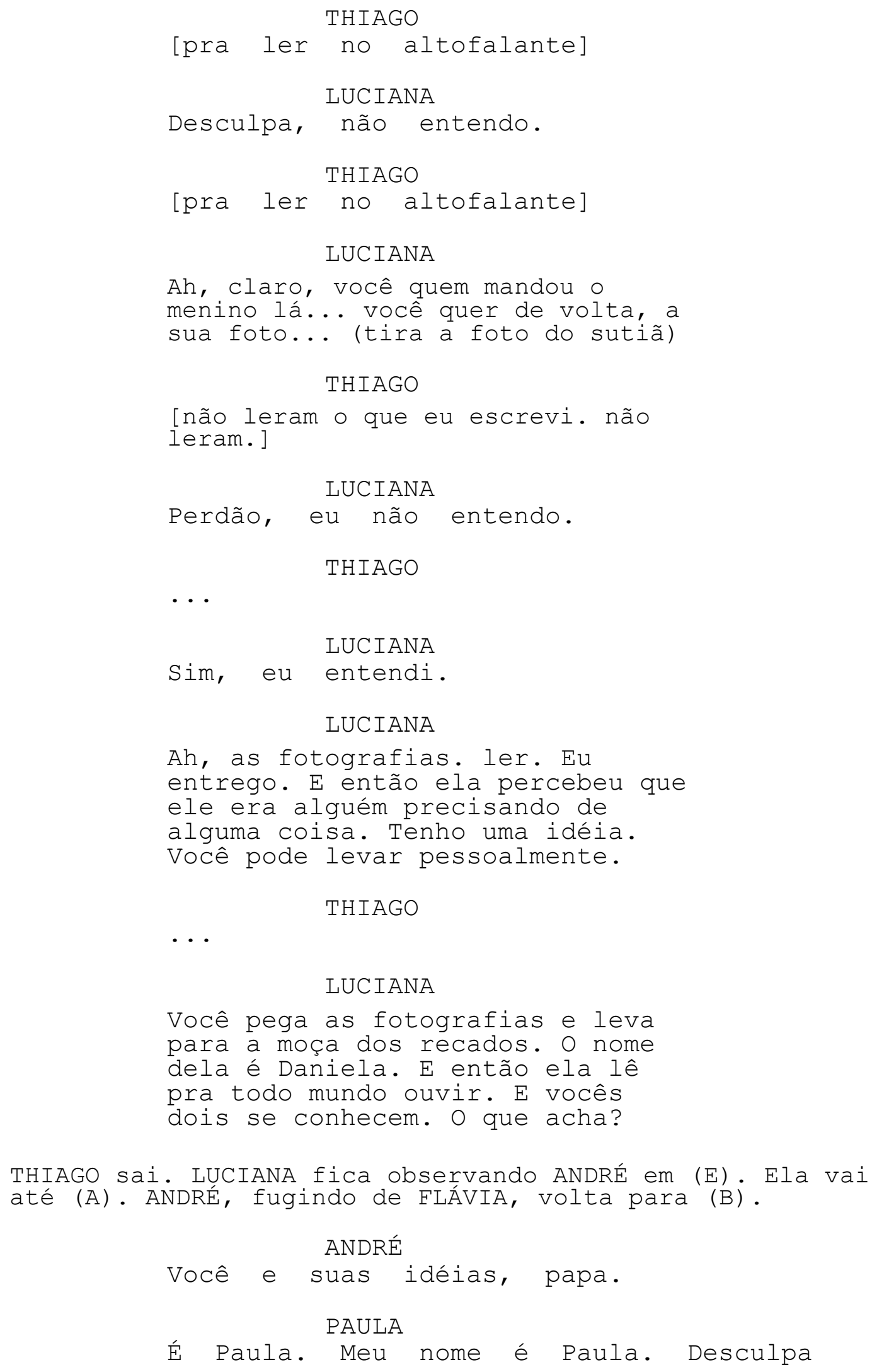

THIAGO sai. LUUCIANA fica observando ANDRÉ em (E). Ela vai até (A). ANDRÉ, fugindo de FLÁVIA, volta para (B). 
ANDRÉ

Você podia me ensinar a soletrar seu nome.

Pra você $\begin{gathered}\text { PAULA } \\ \text { não esquecer. P-A-U-L-A. } \\ \text { ANDRÉ }\end{gathered}$
PAULA.

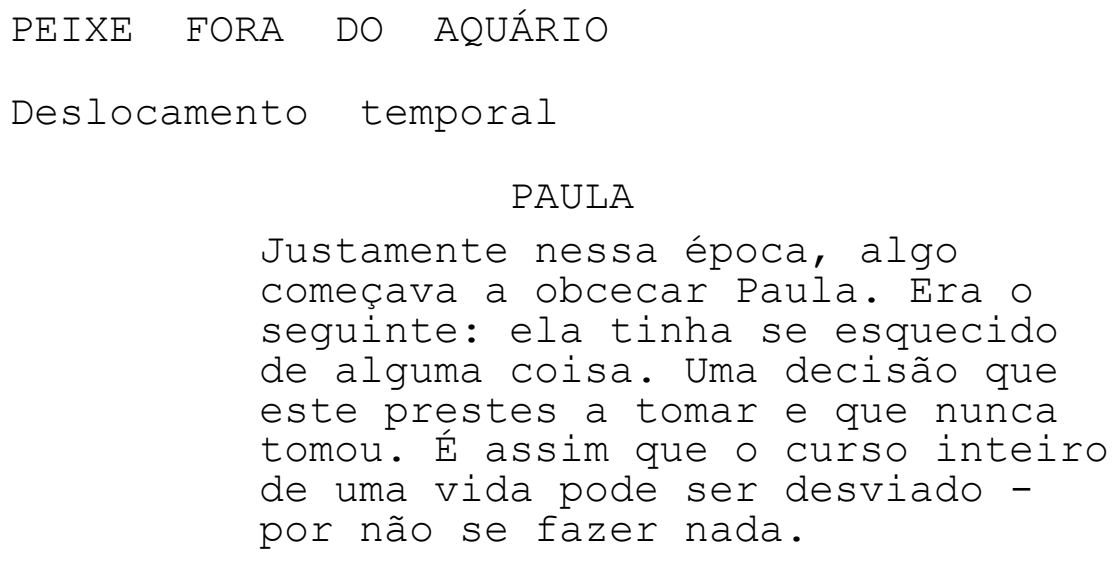

FLÁVIA está ao seu lado. Ela limpa a sujeira da menina.

PAULA

Paula se aproxima da menina e a olha como se olham os cachorros. Aproxima os olhos até quase perder - foco da pele da menina. Ali, embaixo das axilas, uma escama começa a nascer. Fecha os olhos e consegue sentir o cheiro da chuva. Nem a menina pode escutar. Por sorte. Vem chuva aí. C-H-U-V-A.

FLÁVIA

[não medo trovão piscina com chuva não pode]

PAULA

Não. Tranquila.

PAULA

O menino, lembra?, está perto da piscina.

Em (A), ANDRÉ e LUCIANA conversam. MENINO em (F) 


\section{PAULA}

Longe. Ele está de óculos. Está parecendo aquele menino da Turma dos sete, lembra? O mais velho. o retratista está com o menino.

\section{FLÁVIA}

[me conta de novo a história do thiago ]

PAULA

Contar essa história de novo? Não, Flávia.

$$
\begin{gathered}
\text { FLÁVIA } \\
\text { [conta, por favor] } \\
\text { PAULA }
\end{gathered}
$$

Tá bom, te conto. Eu tinha um amigo que queria ser um peixe. P-E-I-X-E.

$$
\text { DANIELA }
$$

$$
(\mathrm{V} \cdot \mathrm{O})
$$

Atenção, às (...) horas da tarde, a piscina (...) ada para que se dê início ao Tor(...) Cegos e Surdos. (pausa) Alô, Alô, acho que não está funcionando...

\section{PAULA}

Quando a gente era criança, em todas as brincadeiras ou eu era bailarina ou eu era uma mulher solteira. E ele era um peixe. Então ele começou a agir como um peixe. No começo todo mundo achou bonitinho. Ele fazia uma boquinha assim. Comia desse jeito. A gente brincava... vai, essa parte você sabe. A gente brincava que o mundo era um aquário, um aquário enorme, cheio de peixes ao nosso redor.

ANDRÉ chega até (C). Deixa Luciana sozinha em (A).

$$
\text { PAULA }
$$

E então ele deixou de falar, foi virando um peixe mesmo. A gente ficava olhando bem forte pro céu, pra ver se achava alguma rachadura no vidro daquele aquário. E achava. 


O que é $\begin{gathered}\text { ANDRÉ } \\ \text { isso?.. Pa, pa... } \\ \text { PAULA }\end{gathered}$

Paula. É um alfabeto, já te expliquei.

ANDRÉ

Você já mandou avisou que a piscina

vai ser isolada... esvaziada?

PAULA

Ai, André. Desculpa. Eu me esqueci. $\mathrm{N}-\mathrm{O}-\mathrm{I}-\mathrm{V}-\mathrm{O}$.

ANDRÉ

E o... na cozinha? Tem, na cozinha?

PAULA

$\cdots$

ANDRÉ

De quem é o torneio? Quem teve a idéia?

Em (A), THIAGO vai falar com LUCIANA. Logo sai, deixando-a sozinha.

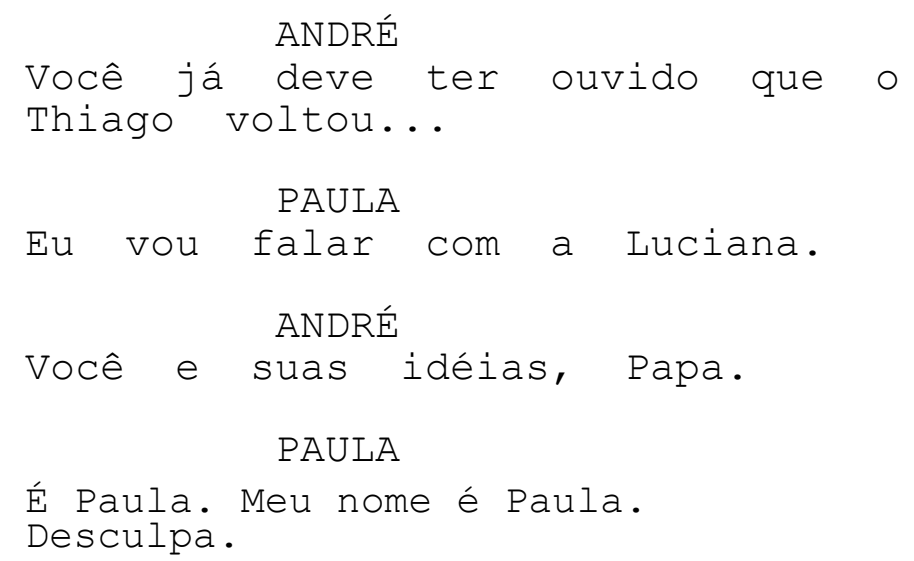

ANDRÉ

Você podia me ensinar a soletrar o seu nome.

Os dois de costas. FLÁVIA se encosta em ANDRÉ, que reage de forma violenta. FLÁVIA foge e vai até (A), onde cruza com LUCIANA, derrubando os papéis e fotografias que ela carrega. Continua e vai até (F), onde cruza com o otÁvio. LUCIANA fica em (A), arrumando a bagunça. Logo, ALINE se aproxima dela. 


\section{PAULA}

Ela só queria te escutar. Agora quem vai ter que correr o clube inteiro atrás dela sou eu.

ANDRÉ

Não é agradável olhar pra ela.

É minha irmã.

PAULA

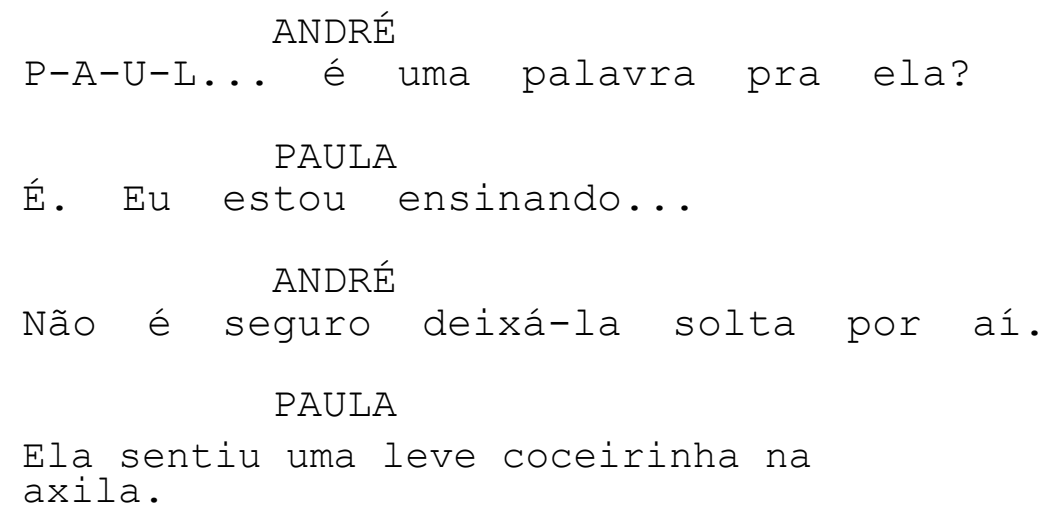

\section{ANDRÉ}

Eu não queria dizer solta. Não fui eu quem decidi te colocar lá. Você passou duas - duas.

Horas .

$$
\text { PAULA }
$$

\section{ANDRÉ}

Isso. Perdi mais uma.

PAULA

Eu vou procurar a menina.

Ela vai sair, cruza com THIAGo, que entra por (B). Ela foge dele e sai por (A). Interrompe a conversa de LUCIANA com ALINE. LUCIANA está sem um dos sapatos.

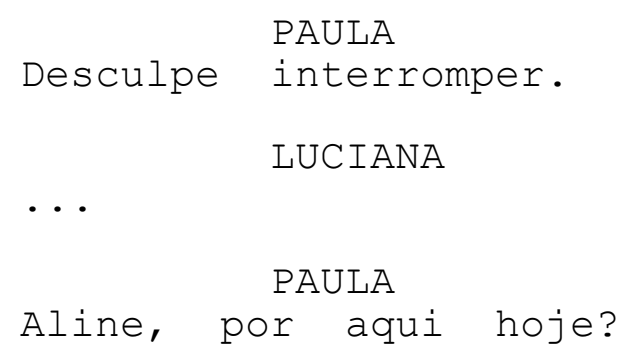




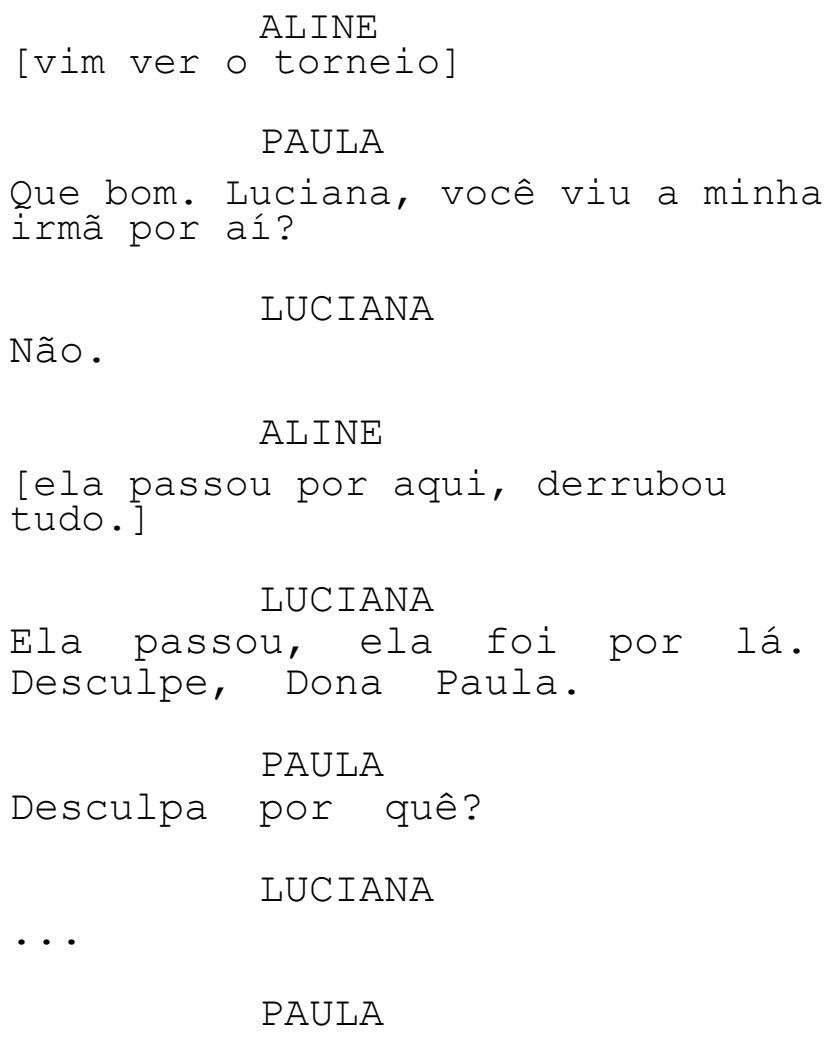

\section{LUCIANA}

Sempre existiria alguém precisando de alguma coisa em algum lugar. Esta era uma certeza que Luciana tinha que ao invés de afligi-la a acalmava. Sempre alguém teria sede, fome, precisaria entrar ou sair do clube, que alguém levasse um recado, precisaria de um sorriso. E esse Alguem sempre seria ela. Seria o seu nome que iriam chamar : "Luciana, Luciana". Luciana gostava que fosse assim, porque ela se sentia indispensável. Luciana sempre lutou contra a sensação de ser coadjuvante do filme preto e branco que contava a história da sua prórpria vida. Ela não se lembra de quando foi a primeira vez que entrou em um aquário, mas achou tudo tão quieto. 
LUCIANA

Ela preferia mil vezes as

histórias e as canções que tocam

no rádio. Ela queria ser a voz e

Arujá. Não porque ela gostasse de

cantar, porque ela gostava de

cantar, mas para que por alguns

minutos as pessoas pudessem parar

de fazer aquilo que elas estavam

fazendo, virassem sua atenção para

ela e esperassem, em silêncio, até

que ela começasse a cantar.

Luciana!

$$
\text { PAULA }
$$

$$
(\mathrm{V} \cdot \mathrm{O})
$$

O MENINO está ao seu lado. Luciana sai por (B). O MENINO Fica sozinho. (C. esq)

MENINO

O menino quis segurar na mão da moça e perguntar se ela gostaria

de ser a nova esposa do pai e os

três iam poder passar as tardes no

clube, com cloro no cabelo.

MARIA AMÉLIA e FERNANDA com seus aquários em (E). DANIELA em (A) .

A EQUIPE DE NATAÇ $\tilde{A} O$

\author{
MARIA AMÉLIA \\ E não precisamos de piscina. \\ FERNANDA \\ Eu coloquei um pouco de açúcar na \\ água. \\ MARIA AMÉLIA \\ $\cdots$ \\ Luciana passa por (C). \\ LUCIANA \\ Dois copos d'água e alguma coisa \\ pra ela comer. Dois copos d'água e \\ alguma coisa pra ela ela comer. \\ Mas eu já levei um copo, tenho que \\ levar outro ou mais dois?
}


FERNANDA

Porque parece ser saudável engolir água doce quente.

\author{
MARIA AMÉLIA \\ $\cdots$
}

FERNANDA

Eu imaginei que podia engolir acidentalmente. As duas iniciam uma pequena aula de natação com aquários.

A VOZ DE ARUJÁ

(A), ao lado de DANIELA.

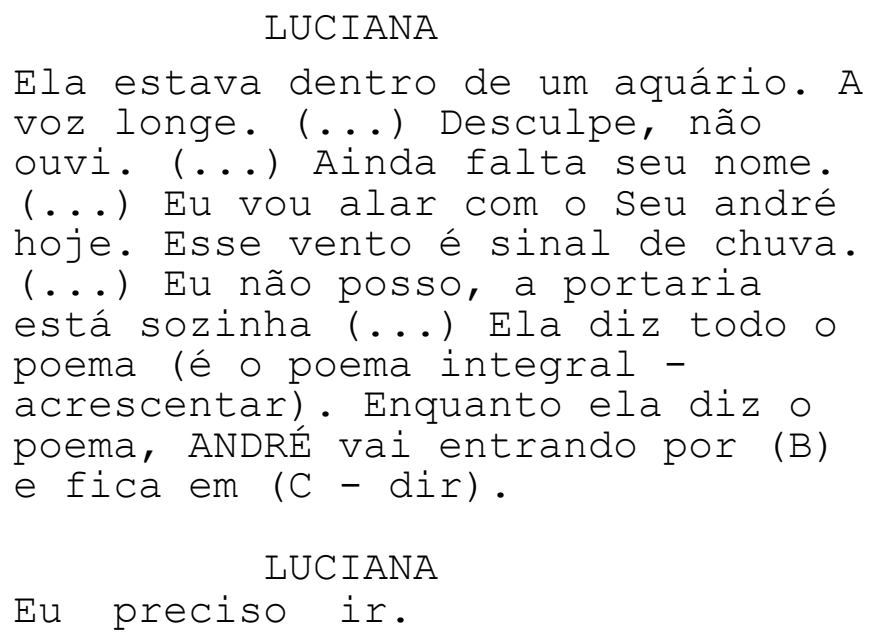

LUCIANA vai até ANDRÉ em (C). Falam em silêncio.

NUVENS DE AÇÚCAR

\title{
DANIELA
}

Quando você chegar, eu vou lhe mostrar que guardei todas as fotografias. E vou lhe contar o que inventei pra cada uma delas. E eu vou gravar o que você me disser porque depois da sua partida, eu posso acabar me esquecendo da sua voz. Eu vou me precaver para não mais te perder. 


\section{A Equipe DE NATAÇÃO}

(E)

MARIA AMÉLIA

Então, vamos acrescentar as pernas e depois os braços.

FERNANDA

Tem certeza de que essas são as condições ideais para se aprender a nadar?

\section{MARIA AMÉLIA}

Admito que não são. Mas é assim que os nadadores olímpicos treinam quando não há pisicna por perto. Mentiu. Mas elas precisavam daquilo porque eram duas mulheres deitadas no chão da cozinha, chutando-o como se estivessem zangadas, como se estivessem furiosas, como se estivessem desapontadas e sem medo de mostrar isso.

\section{A VOZ DE ARUJÁ}

(C)

\section{LUCIANA}

Eu queria saber se vocês vão permitir que fucionários do clube se inscrevam.

ANDRÉ

Você gostaria de participar, é isso, Luciene?

LUCIANA

Queria.

ANDRÉ

Quer dizer que temos uma (pausa)

qual o nome daquele pássaro?

LUCIANA

Pássaro?

ANDRÉ

É. Perdi a palavra. Aquele que canta. 


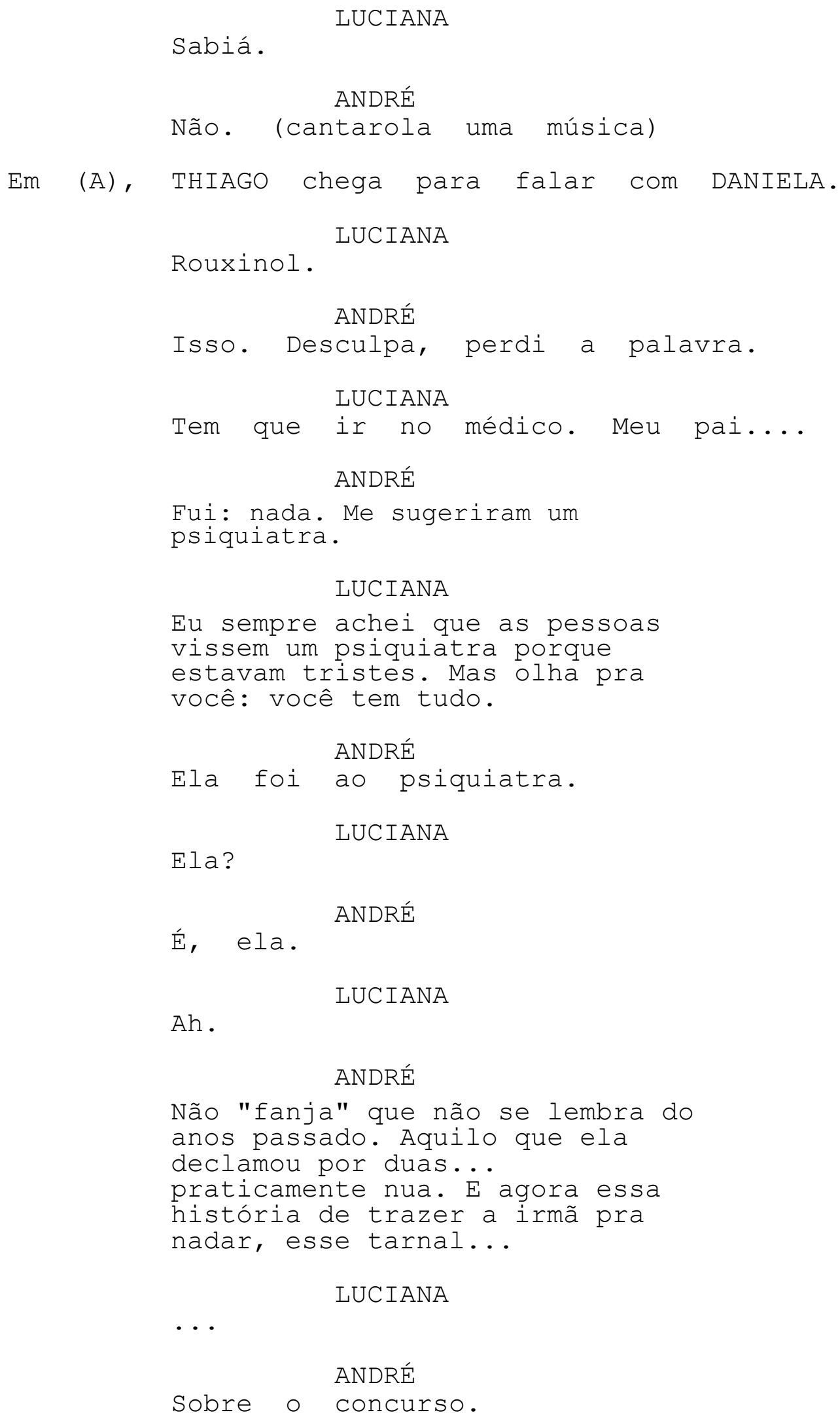

ANDRÉ

Não "fanja" que não se lembra do anos passado. Aquilo que ela declamou por duas... 


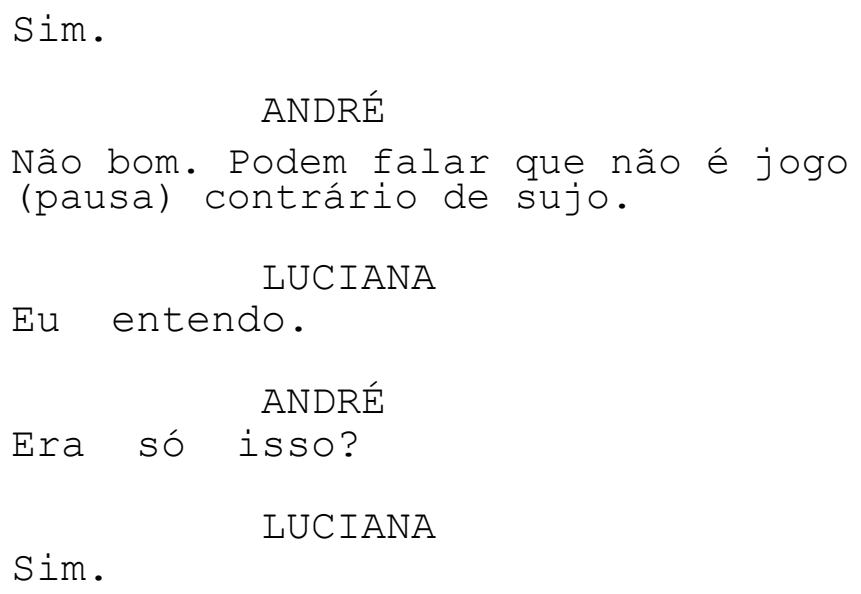

\section{LUCIANA}

E ela não ouviu mais nada. Dentro dela, havia agora um aquário contendo um minúsculo girino sem apetite, nadando pra frente e pra trás, pra frente e pra trás, pra frente e pra trás.

A Equipe DE NAtAÇ̃̃o

FERNANDA

Fernanda achou que o chão da cozinha fosse ceder e virar líquido.

\section{MARIA AMÉLIA}

Não se esqueça de usar os braços, seus pés estão pra cima, mas sua cabeça está afundando. E agora o mergulho. Isso. 


\section{A VOZ DE ARUJÁ}

FLÁVIA vem de B, fugindo. Cruza com LUCIANA e derruba tudo - que ela tem nas mãos. FLÁVIA sai fundo. LUCIANA fica limpando o chão, sozinha, cantarolando alguma coisa. ALINE entra.

(B)

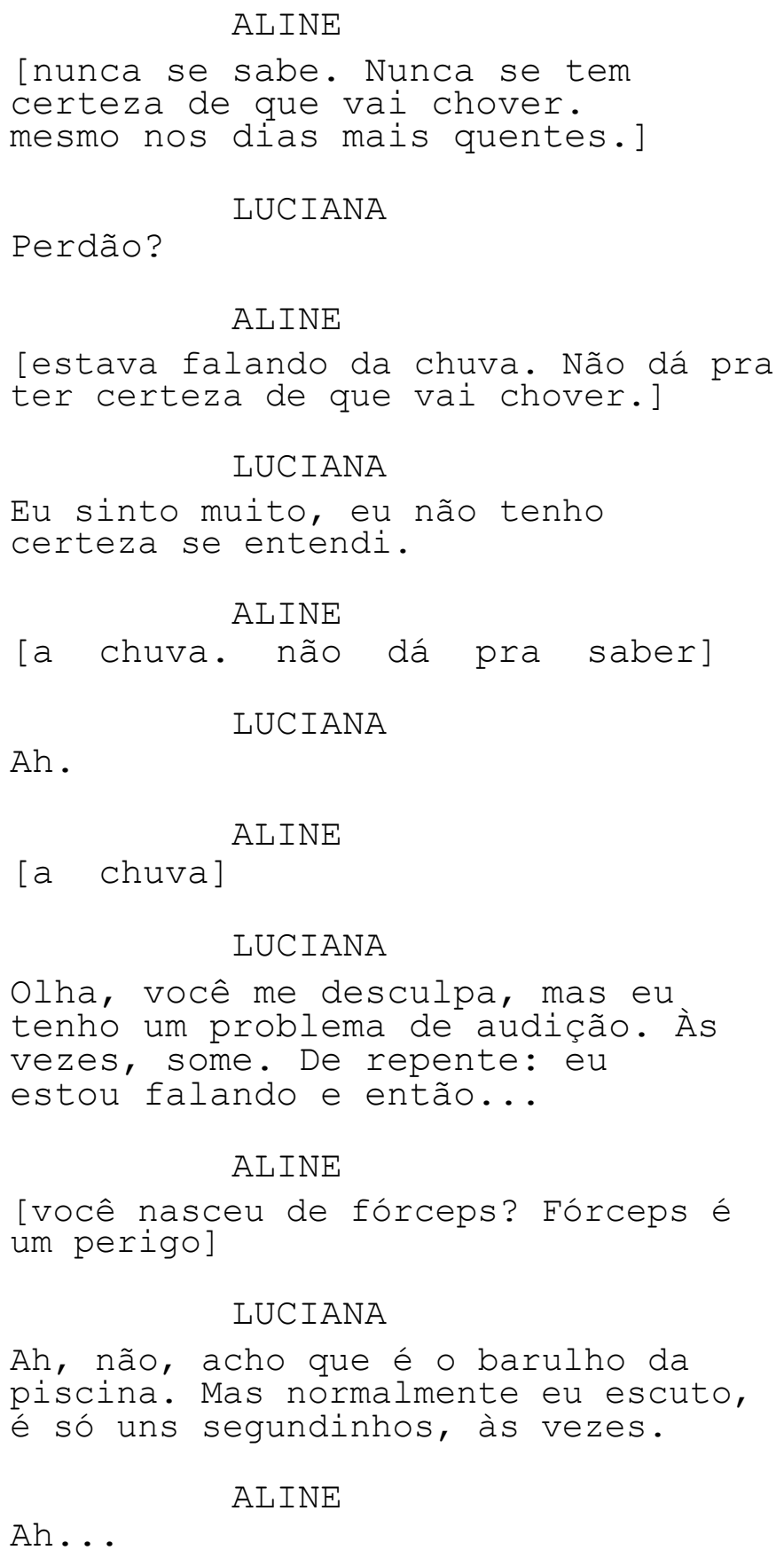

\section{LUCIANA}

Ah, não, acho que é o barulho da piscina. Mas normalmente eu escuto, é só uns segundinhos, às vezes.

Ah...

ALINE 
LUCIANA

Um girino escapa de sua boca entreaberta, nada freneticamente e mergulha na piscina. Eu falei com você ontem no baile: sempre olhando a piscina. Você vem todos os dias, não é?

\section{ALINE}

[todos os dias. Segundas, tenho experimentos aquáticos.]

LUCIANA

○ quê?

ALINE

[experimentos aquáticos]

LUCIANA

Experimentos aquáticos? Não sei o que é.

ALINE

[segunda feira. A gente faz conversação debaixo d'água.]

LUCIANA

Vocês conversam debaixo d'água?

a gente treina]

$$
\text { ALINE [é, }
$$

$$
\text { LUCIANA }
$$

Vocês treinam falar debaixo d'água?

[é, é mais ALINE

\section{LUCIANA}

Ah, deve ser o tratamento. Você percebeu? Aconteceu de novo. Eu não ouvi o que você falou.

\section{ALINE}

[não dá pra saber, mas parece que vai chover]

LUCIANA

Ah, então é isso. É o tratamento que tem às segundas. Eu achei que só rapazes... 


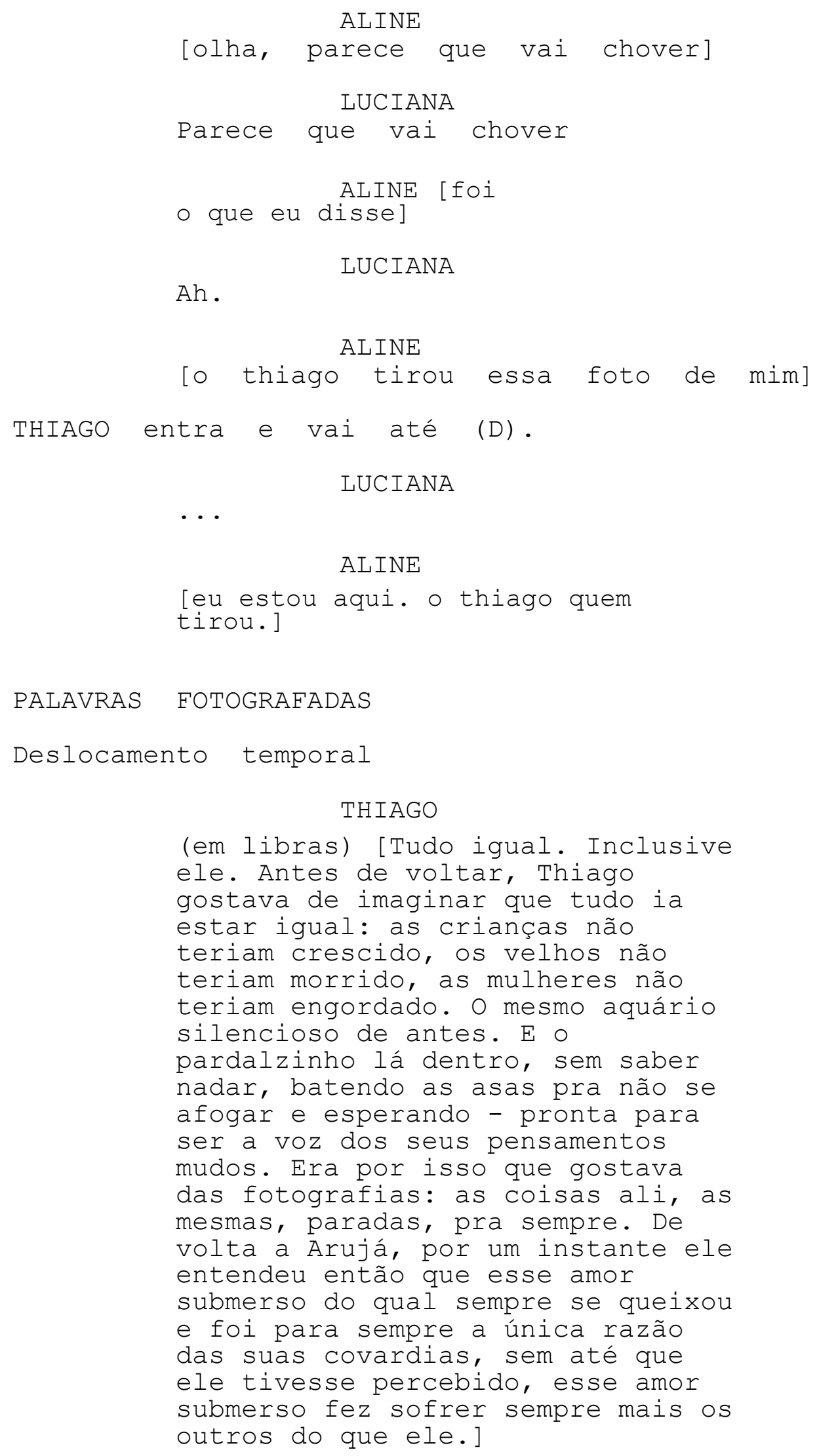


Simultaneamente, O MENINO (C.esq) lê o que está escrito na fotografia que recebeu dele - em voz alta, com a fotografia bem perto do rosto.

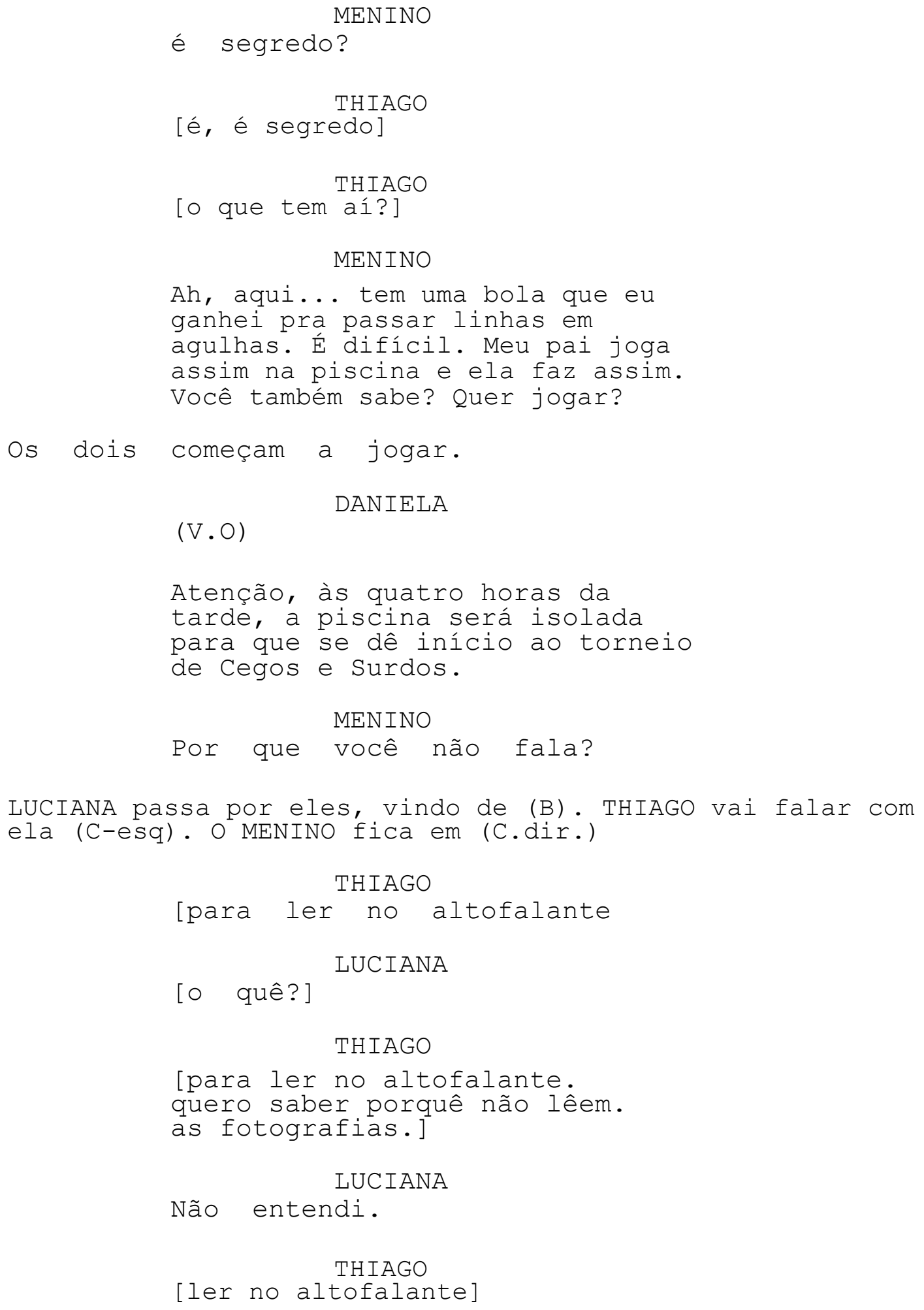




\section{LUCIANA}

Ah, oi você quem mandou o menino

lá... você quer de volta, eu não

entendi nada, essa história de

(lendo) manifesto... moças não

são muito boas com política, né?

Olha, está aqui, de volta.

THIAGO

[não. é pra ler no altofalante].

LUCIANA

Desculpa, eu não entendo. Eu não

tenho tempo pra isso.

THIAGO

[não precisa gritar comigo]

LUCIANA

Faz assim: você leva pra Daniela, a moça do altofalante e pede pra ela ler pra você. Daniela.

THIAGO vai até C-direita, onde já está DANIELA. LUCIANA sai. MENINO permanece sentado em (D).

\section{III - ENCONTROS}

CENA 1

$(\mathrm{C}-\mathrm{DIR})$

THIAGO se aproxima de DANIELA, trazendo as fotografias.

DANIELA

Atenção, às quatro horas da tarde,

a piscina será isolada...

(percebendo a presença de alguém)

Luciana. Tem que avisar o Wilson, o som vazou...

[Você é a moça dos avisos?]

DANIELA

Você veio.

Ela abre os braços. THIAGo se aproxima dela. 
DANIELA

Eu estava te esperando. Você quer tomar alguma coisa? Um café, uma bebidinha mais forte... eu peço pra Luciana.

THIAGO

[eu trouxe o manifesto para que vocês leiam no clube. É muito importante que seja hoje]

DANIELA

Nossa, é um prazer tê-lo aqui. Se você me der o prazer, eu gostaria muito de dizer algumas das suas palavras (começa o poema)

Ele percebe que ela é cega. Ela permanece imóvel. Um tempo entre eles. os dois esperam que algo aconteça. Ele finalmente lhe entrega outras fotografias.

\section{THIAGO}

$\cdots$

DANIELA

Thiago limpa o açúcar no rosto e na roupa de Daniela. Ela se constrange um pouco. Se afasta rápida e cuida para ela mesma limpar.

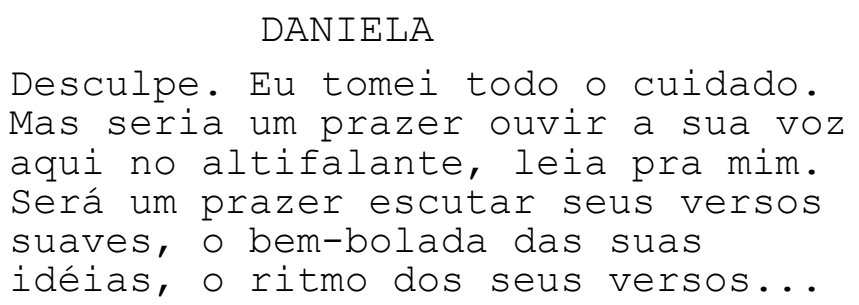

THIAGO vai embora por (B)

DANIELA

Lê pra mim. Pra eu ouvir sua voz.

Ela finalmente percebe que THIAGO saiu. Daniela permanece em (C-direita). 
CENA 2

(A)

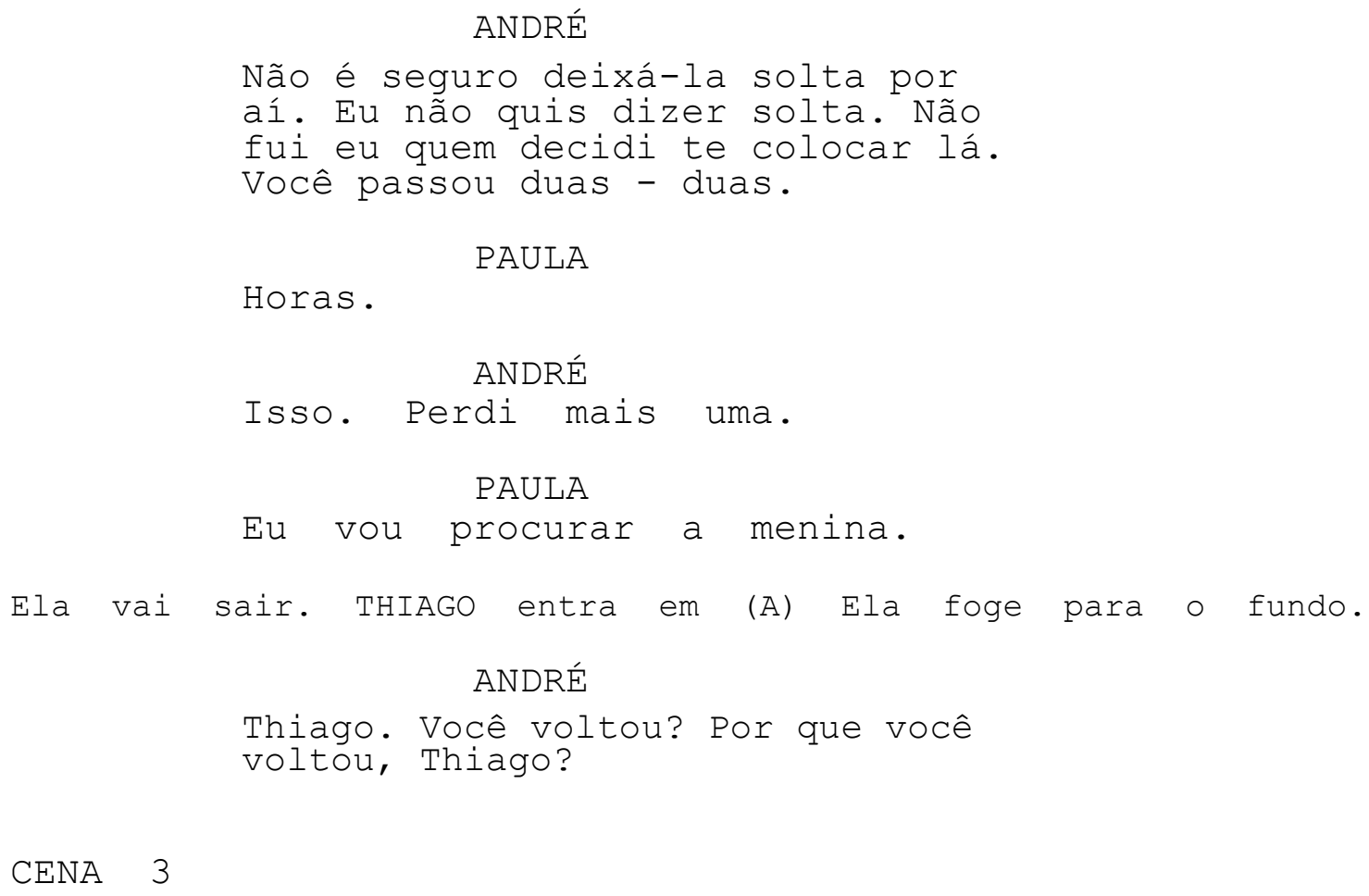

LUCIANA sai de (B)-fundo e cruza com FLÁVIA (de B) . Encontro das duas. As revistas de LUCIANA espalhadas em (B). MENINO se aproxima dela. Os dois de mãos dadas caminham até (D). ALINE vem se aproximando de LUCIANA.

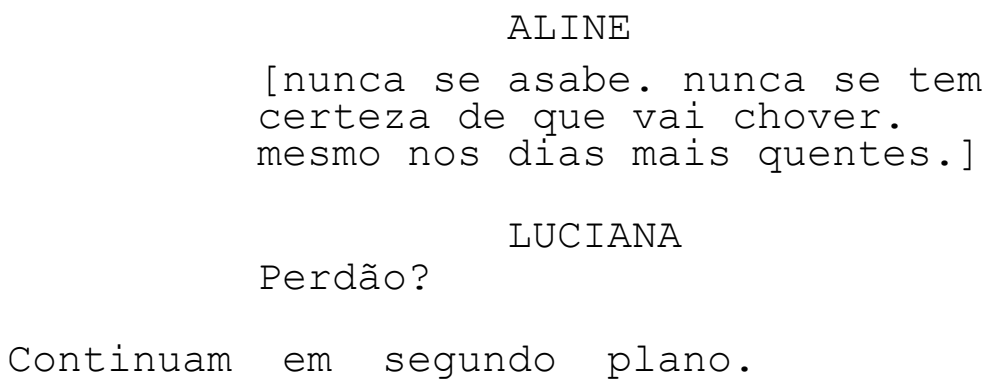

(D) 
MENINO e FLÁVIA brincam e riem muito alto. Os dois se divertem com alguma brincadeira bem simples. A menina tira os óculos dele, ele resiste, com medo. Na segunda vez, ela consegue colocar seus óculos e se diverte. O MENINO força a vista.

$$
\begin{gathered}
\text { FLÁVIA } \\
\text { [não óculos. não torneio] }
\end{gathered}
$$

CENA 5

$(\mathrm{A})$

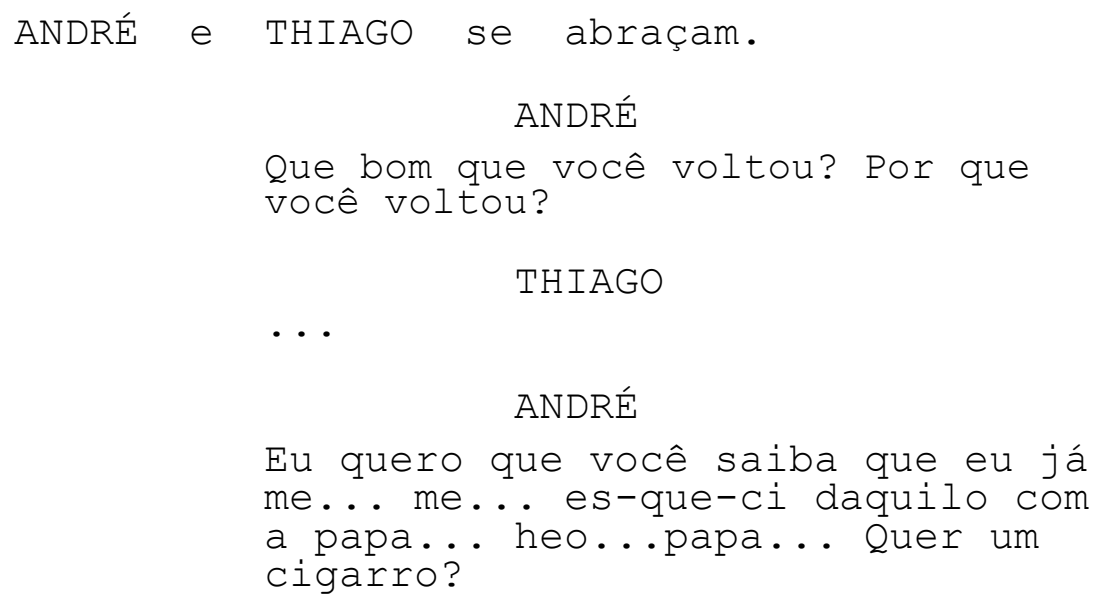

CENA 6

$(\mathrm{C}-\mathrm{dir})$

No altifalante.

DANIELA

As inscrições para o Concurso A

Voz de Arujá estão encerradas. Boa

sorte a todos os competidores.

CENA 7

(B)

As duas ouvem o altifalante.

ALINE
[você se inscreveu?] 


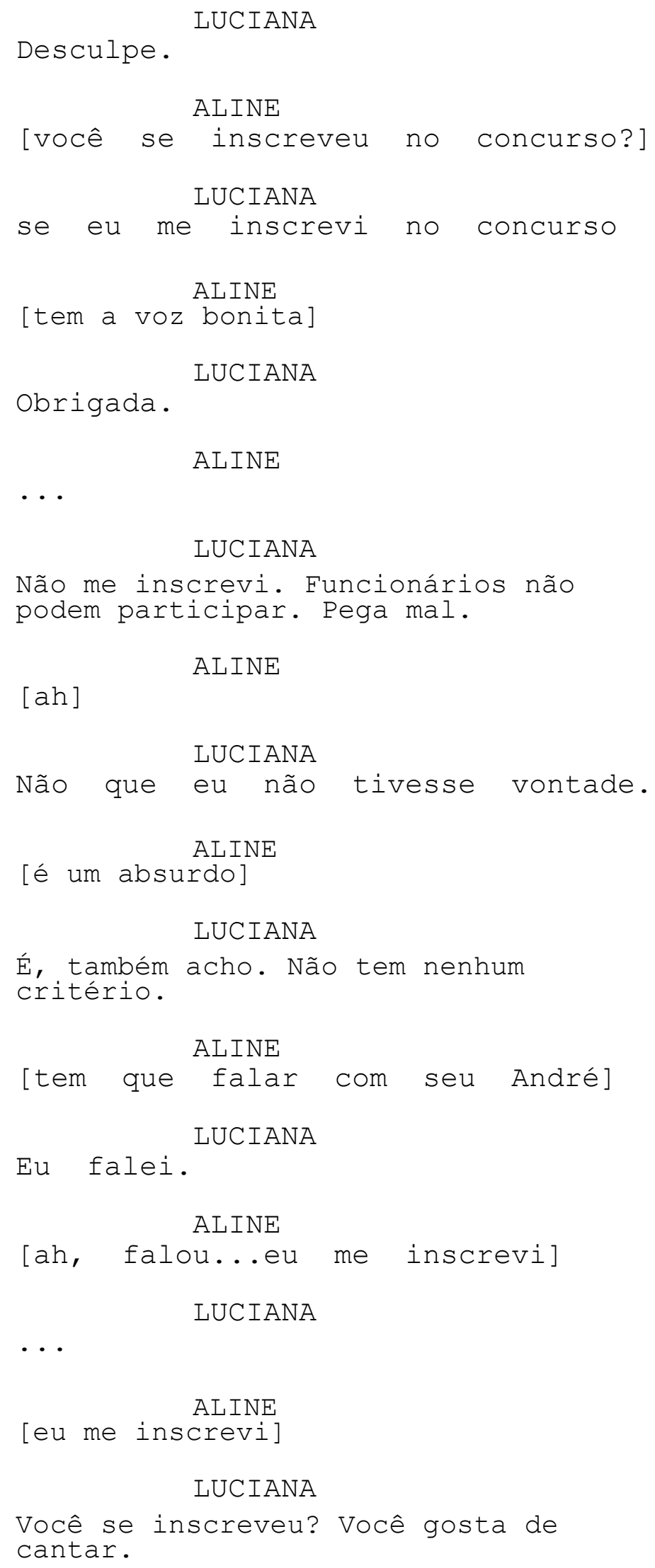




\section{ALINE}

CENA 8

\section{$(\mathrm{A})$}

ANDRÉ mostra os guardanapos para THIAGO, que o escuta atentamente.

\section{ANDRÉ}

Perdi "muito" (ela não diz, mostra

- guardanapo) certa tarde com a moça da recepção, perdi "bom" quando o barbeiro me virou de frente para o espelho, perdi "vergonha" com a (pausa) minha noiva; perdi. Desculpa te dizer-er isso: mas cada momento de cada dia me quebra o coração em mais "fedaços" do que meu coração é feito... aquilo que vocês

aprontaram no Clube, aquele manimanifesta... foi duro, é claro, nunca pensei em (pausa) como uma pessoa quieta-ieta, que dirá calada, nunca pensei nas coisasoisas, tudo mudou, o vão-vão que se encravou entre (pausa) e a felicidade -ohnmte... não foi o mundo, não foi (pausa) ela, não foi o Castro e toda aquela história de Cuba. fui (pausa), foi meu pensamento. Meu pensamento agora é guarda-guardanapo.

THIAGO está incomodado. A fala de ANDRÉ começa a não fazer sentido.

CENA 9

(B)

ALINE

[eles não aceitaram a minha inscrição]

LUCIANA

Não é você, é meu ouvido, desculpe. 


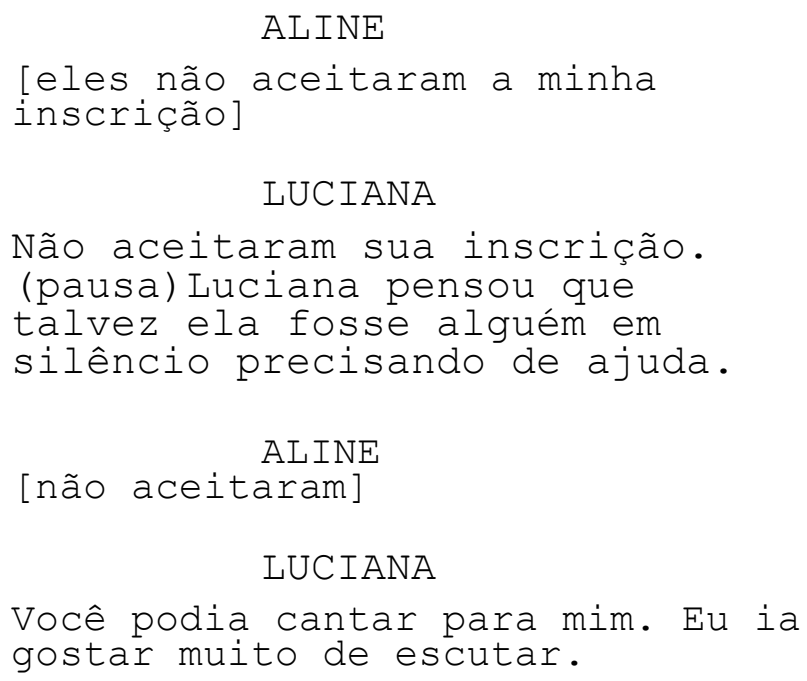

CENA 10

$(\mathrm{F})$

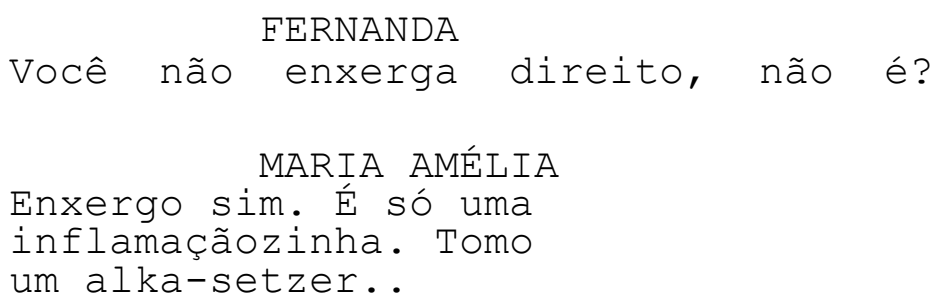

FERNANDA aproxima suas mãos dos olhos de MARIA AMÉLIA. MARIA AMÉLIA se afasta, FERNANDA continua.Limpa a secreção do olho de MARIA AMÉLIA.

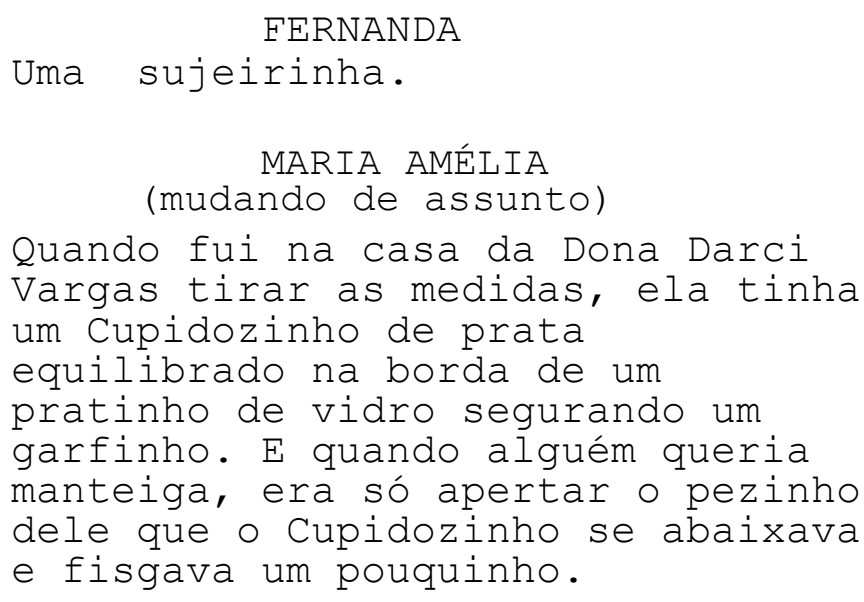




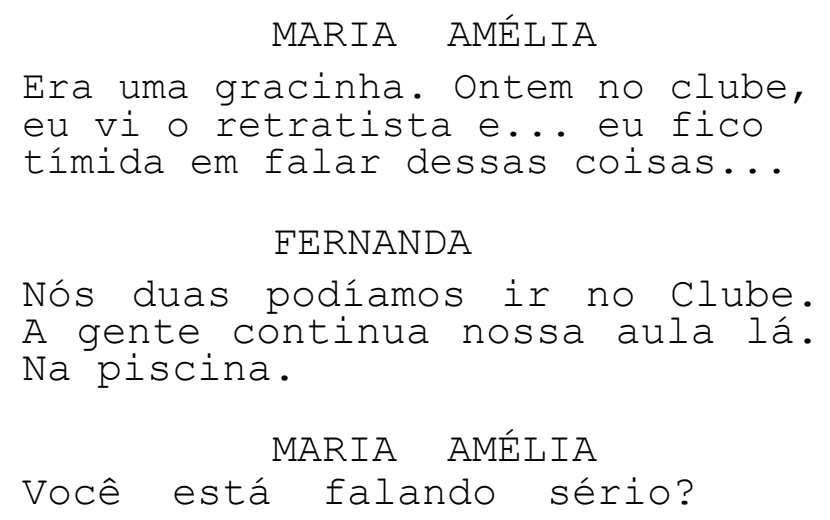

(B)

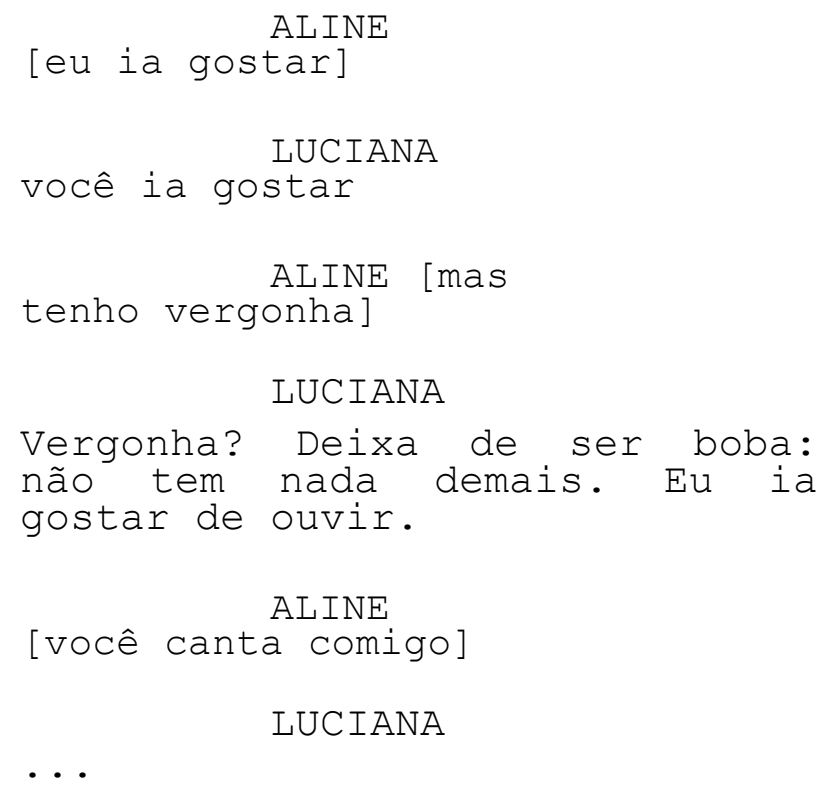




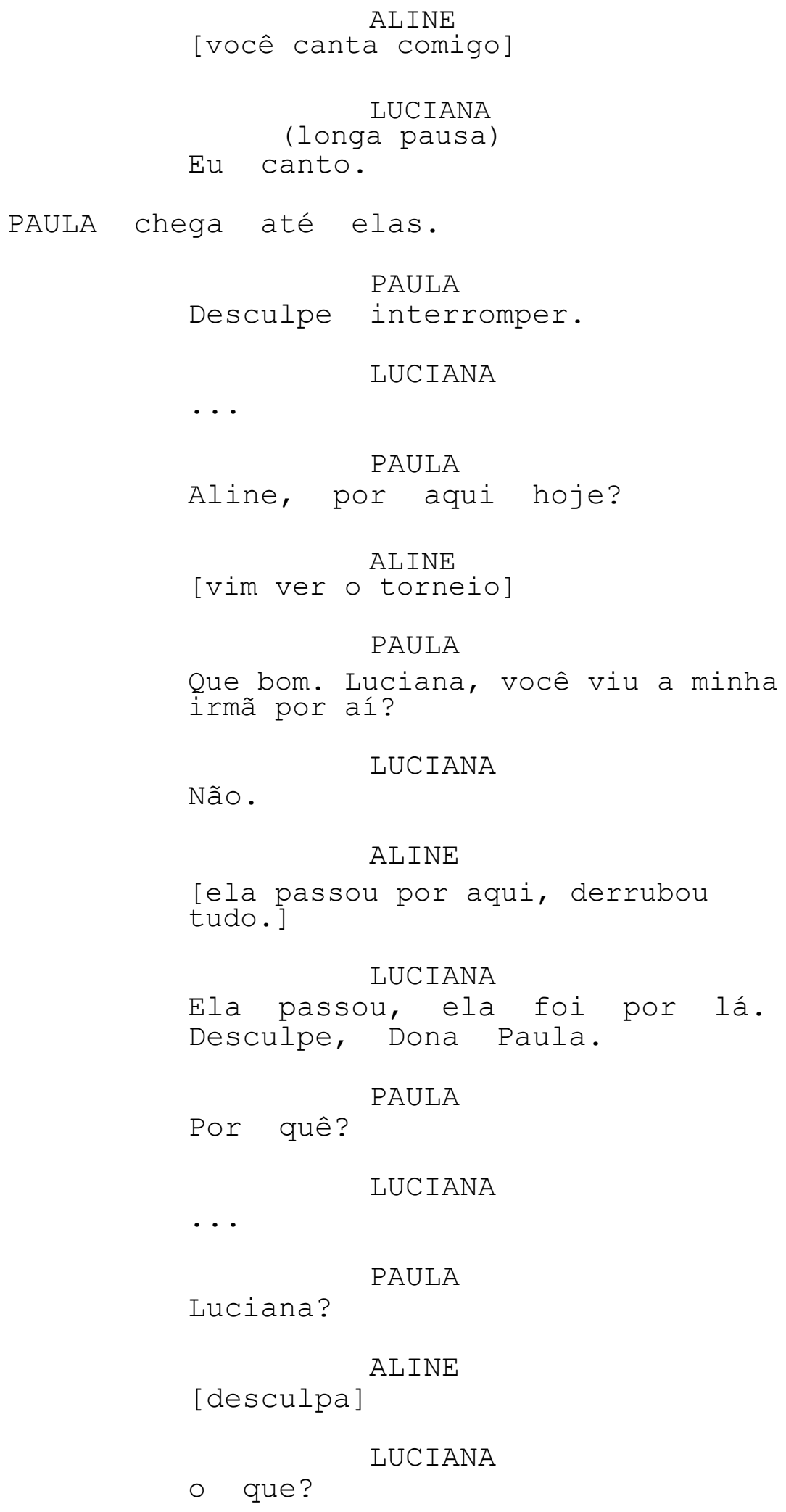




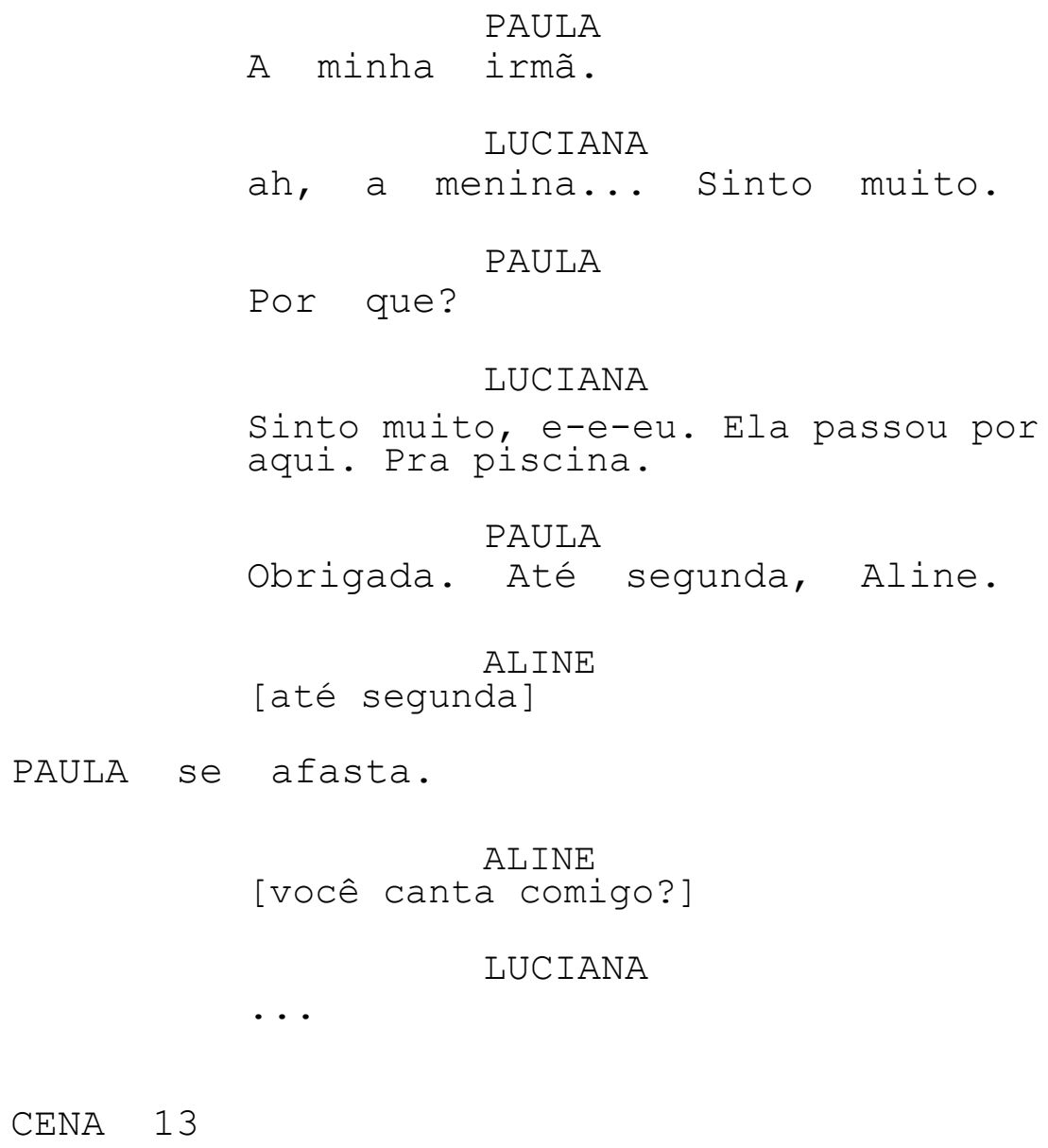

FLÁVIA o empurra com violência e sai (B). Ele fica ali (D), meio perdido, sem enxergar direito. PAULA procura a irmã em $(F)$.

CENA 14

\section{$(\mathrm{A})$}

THIAGO pega os guardanapos de André. Escreve sobre eles e entrega a ANDRÉ. ANDRÉ lê e fica um pouco atordoado. 
ANDRÉ

Ela é minha n-n-noiva. Eu... não... atitude, atitude.

THIAGO sai.

CENA 15

(D)

PAULA vem de (F) ese aproxima de O MENINO. Ela ainda procura por FLÁVIA.

PAULA

O menino à beira da piscina

parecia esperar que eu fosse em

frente. E não esperávamos todos?

MENINO

Eu tenho um cachorro.

PAULA

Você viu uma menina?

MENINO

Eu tenho um cachorro.

PAULA

E qual é o nome dele? (pausa)O garoto pareceu triste por um

instante, e eu entendi que ele na verdade não tinha um

cachorro. Me senti honrada por

ter sido escolhida como a pessoa

que acreditava que ele tinha um

cachorro.

MENINO

Você tem um cachorro?

Não .

PAULA

MENINO

Nem um gato?

PAULA

Não •

MENINO

Por que não? 
PAULA

Não sei se eu poderia cuidar de um

bicho. Ela teve vontade de dizer que não tinha nada a oferecer, a não ser sua própria confusão.

MENINO

○ que?

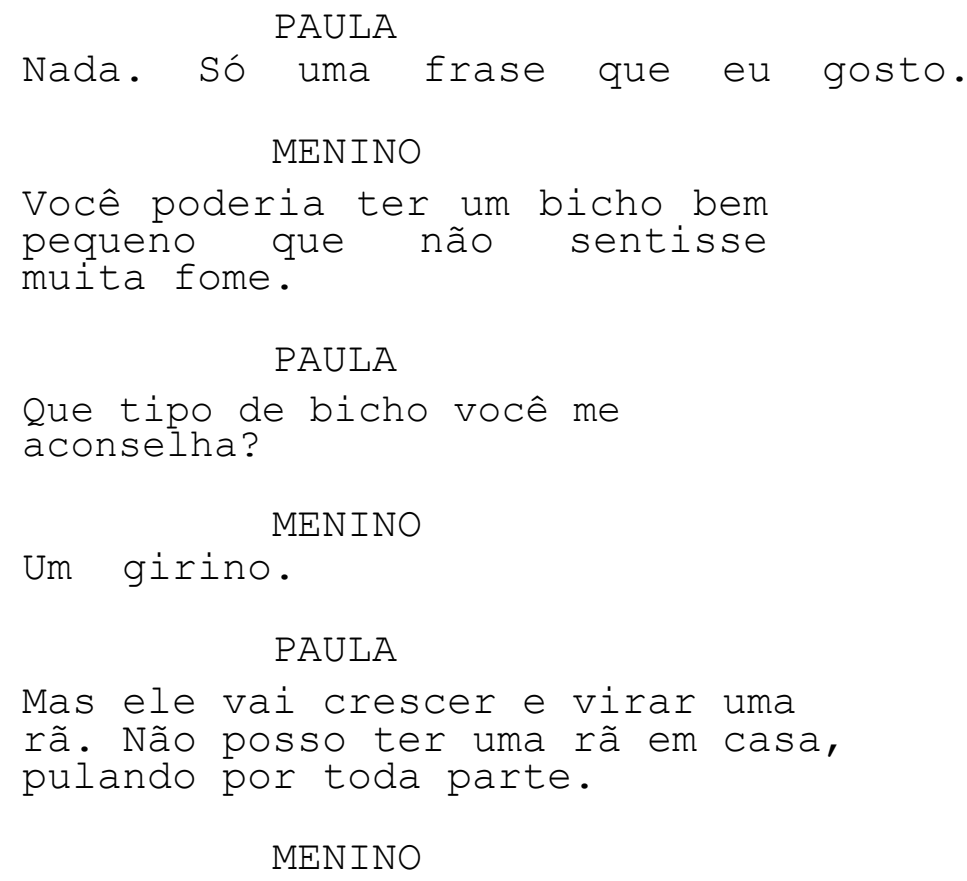


PAULA

Hoje eu vou embora. Quando o torneio acabar, eu vou. (pausa). Eu tive um amigo parecido com você. Ele queria ser peixe.Um dia, eu já não sei se é memória ou imaginação, mas vi uma escama debaixo do braço dele.Começaram uns rumores pela casa, meus pais, os tios cochichando pelos cantos. Ele logo parou de falar. Com aquela boquinha de peixe. Compraram um aquário. Ele vinha nadar aqui, como você, mas ele nunca entrou na piscina: ficava só com os pés na água. Eu acreditei nele: ele era um peixe, eu sei. Ele gostava de tirar fotos minhas. Mas levaram o meu peixinho embora. Eu devia ter aprendido a parar de falar dessas coisas. Eu devia parar.

MENINO

Qual o nome dele? Do seu amigo peixe?

PAULA ... MENINO A

moça pareceu triste por um

instante, e eu entendi que ela na verdade não tinha mais um amigo peixe.

\section{PAULA}

Eu tenho que achar a minha irmã .

Ela vai sair por (B). THIAGO aparece e a persegue até (C-esq). Começam a conversar em libras.

CENA 16

(A)

ANDRÉ lê O bilhete de THIAGO (definir)/ ENSAIA DISCURSO

ANDRÉ

É um pra-prazer recebê-los a (...)

Tenho o p-prazer de apresentar 0

Primeiro Concurso A Voz - a voz... 
CENA 17

$(\mathrm{F})$

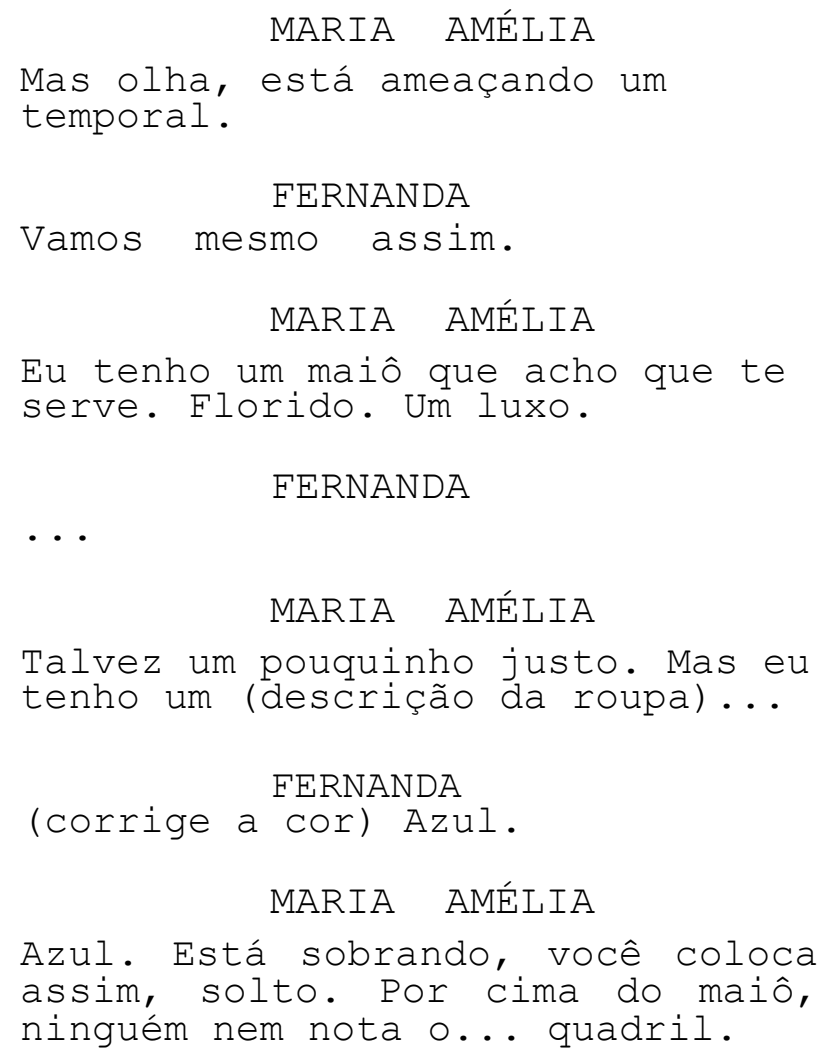




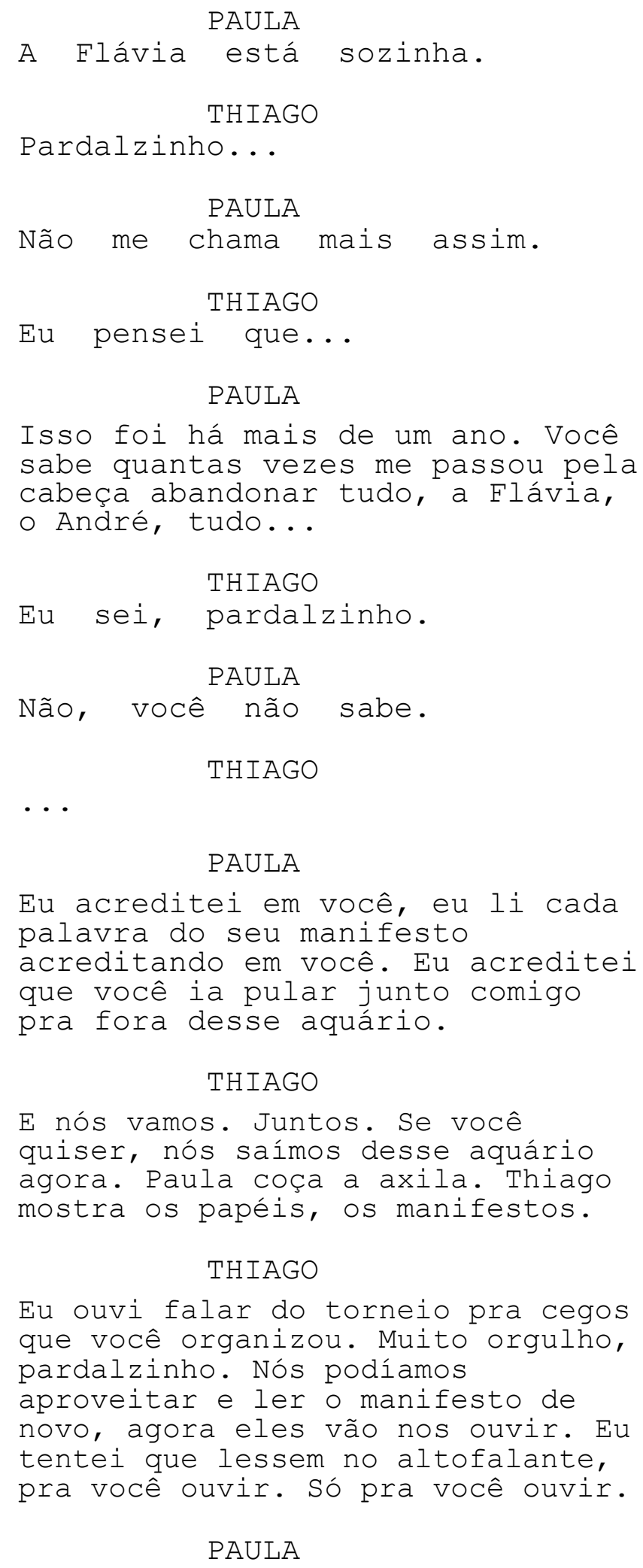


THIAGO

Olha, ainda está tudo aqui. Eu pensei nisso todos os dias em que estive longe. Era só em você e na sua irmã que eu pensava.

PAULA

$\cdots$

THIAGO

Acredita em mim, pardalzinho. Ia ser pior se eu tivesse ficado. Eu sei que não deve ter sido fácil pra você e pra Flávia. Mas agora é diferente.

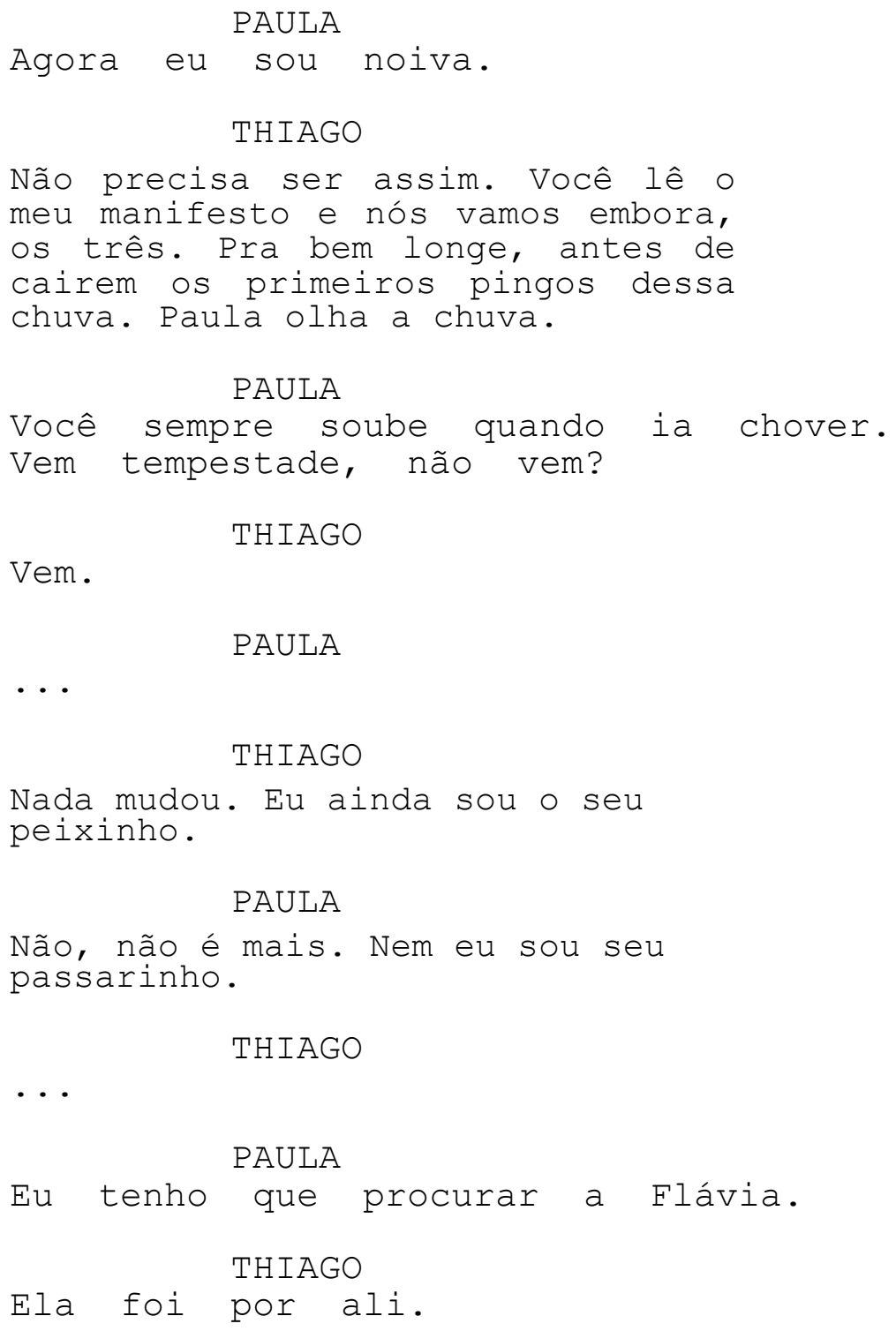




$$
\text { Eu sinto muito. }
$$

Ela continua a procurar por FLÁVIA (sai por B). THIAGO muito decepcionado, permanece em (C.esq).

CENA 19

(B)

PAULA passa por ALINE e LUCIANA.

$$
\begin{aligned}
& \text { ALINE } \\
& \text { [as duas juntas] } \\
& \text { LUCIANA } \\
& \text { Você conhece aquela - da Dalva da minha } \\
& \text { (canta) Que será... da... } \\
& \text { vida. ALINE } \\
& \text { [essa é boa] }
\end{aligned}
$$$$
\text { Você conhece aquela - da Dalva: }
$$

ALINE canta junto com LUCIANA. LUCIANA pára, constrangida. ALINE começa a chorar. Um tempo.

\section{LUCIANA}

Podemos cantar outra. Não tem problema.

$$
\begin{gathered}
\text { [não, essa é boa }] \\
\text { LuCIANA } \\
\text { Lstá tudo bem? }
\end{gathered}
$$

$$
\begin{gathered}
\text { ALINE } \\
\text { [desculpe. é que] }
\end{gathered}
$$

As duas cantam, muito emocionadas.

Enquanto ouvimos as duas cantarem, acompanhamos os personagens sozinhos.DANIELA (C.dir) continua a se ajeitar, segurando as fotografias, como se ainda esperasse. THIAGO (C.esq) olha seu manifesto-fotografia diante da piscina, desolado. ANDRÉ (A) continua a tentar falar o seu discurso, em vão. PAULA procura por FLÁVIA em (F). O MENINO (D) está de pé, mal consegue enxergar, procurando os óculos. FLÁVIA perdida (B), chora. THIAGO decide sair. Sincronia.

PAULA e FLÁVIA se reencontram em (C.dir). 


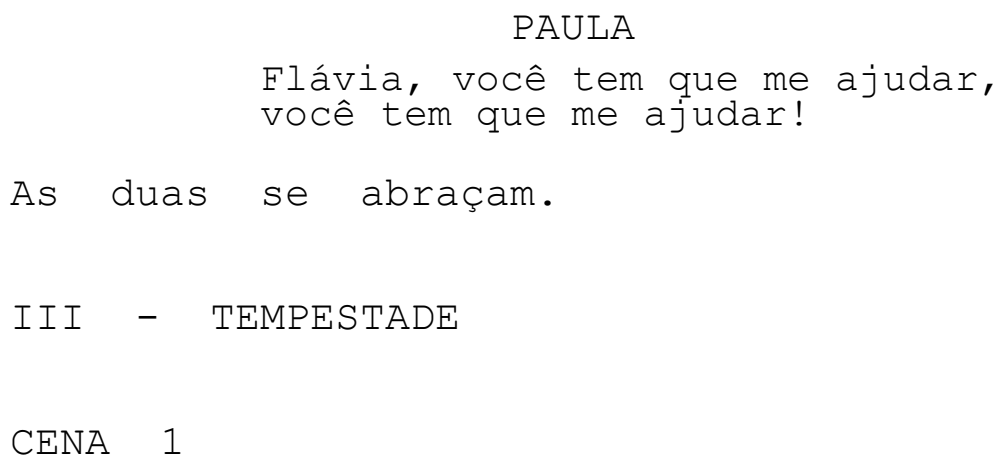

(B)

\section{LUCIANA}

Agora eu tenho que ir. Gostei muito.

ALINE
[eu também. muito]

LUCIANA
Eu saio às quatro e trinta.

Luciana vai até (A).

Aline fica sozinha em (B) .

CENA 2

(C.esq)

PAULA deitada no colo de FLÁVIA.

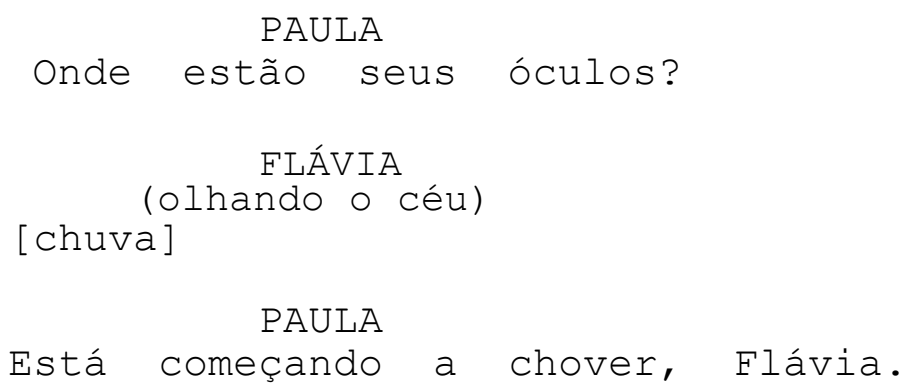

CENA 3

(A)

ANDRÉ

É com p-prazer. Às margens da Presidente Dutra o Clube américa. 
ANDRÉ

Clube atlético. (pausa) Hoje, a emancipa-emancipação de (não consegue continuar) Na história de Arujá-já (pausa).

Vai perdendo mais as palavras.

CENA 4

(de B até C.fundo)

MARIA AMÉLIA e FERNANDA chegam ao clube.

LUCIANA

As carteirinhas, faz favor.

FERNANDA entrega sua carteirinha.

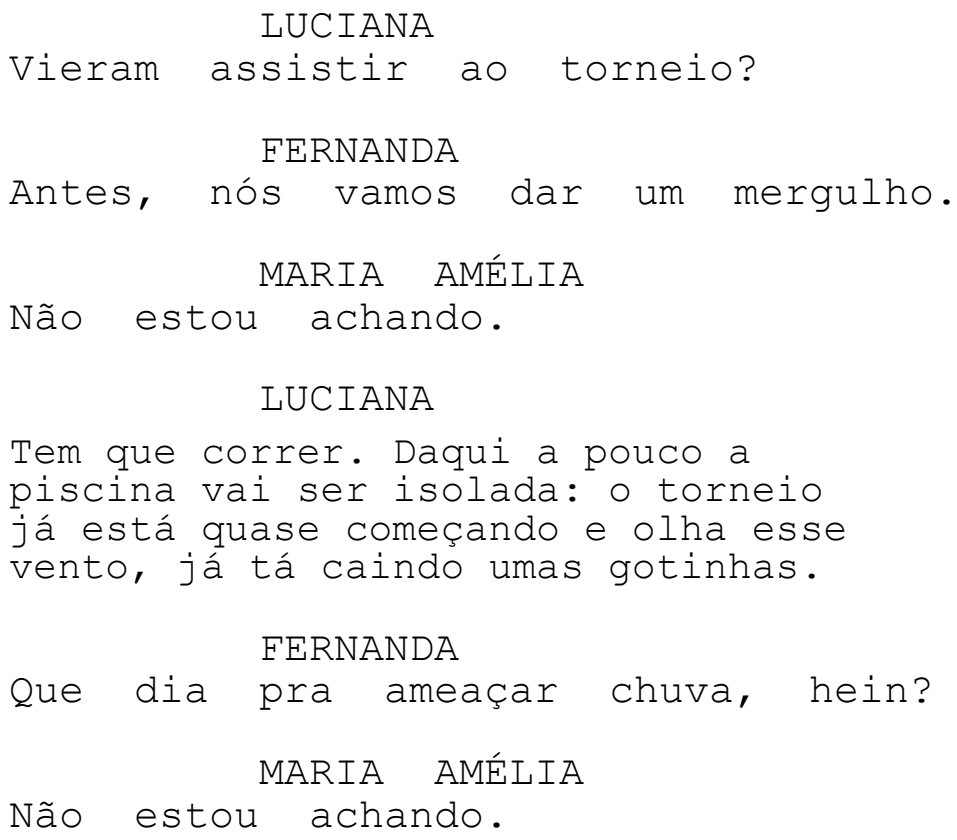




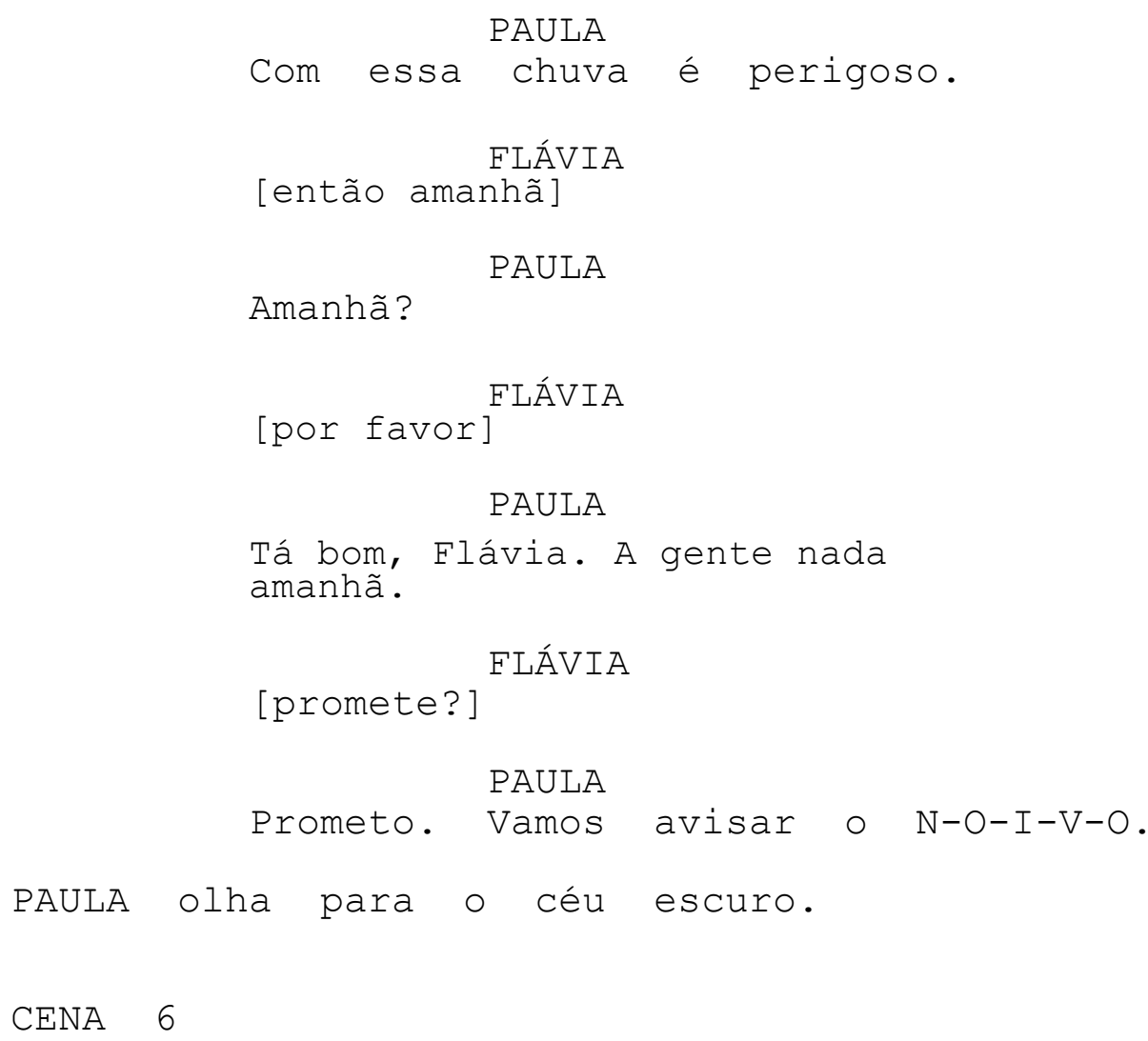

\section{LUCIANA}

Sinto muito. Sem a carteira não posso autorizar.

FERNANDA

Ela estava aqui ontem, no sábado Dançante.

LUCIANA

Eu p-p-preciso do exame médico. 


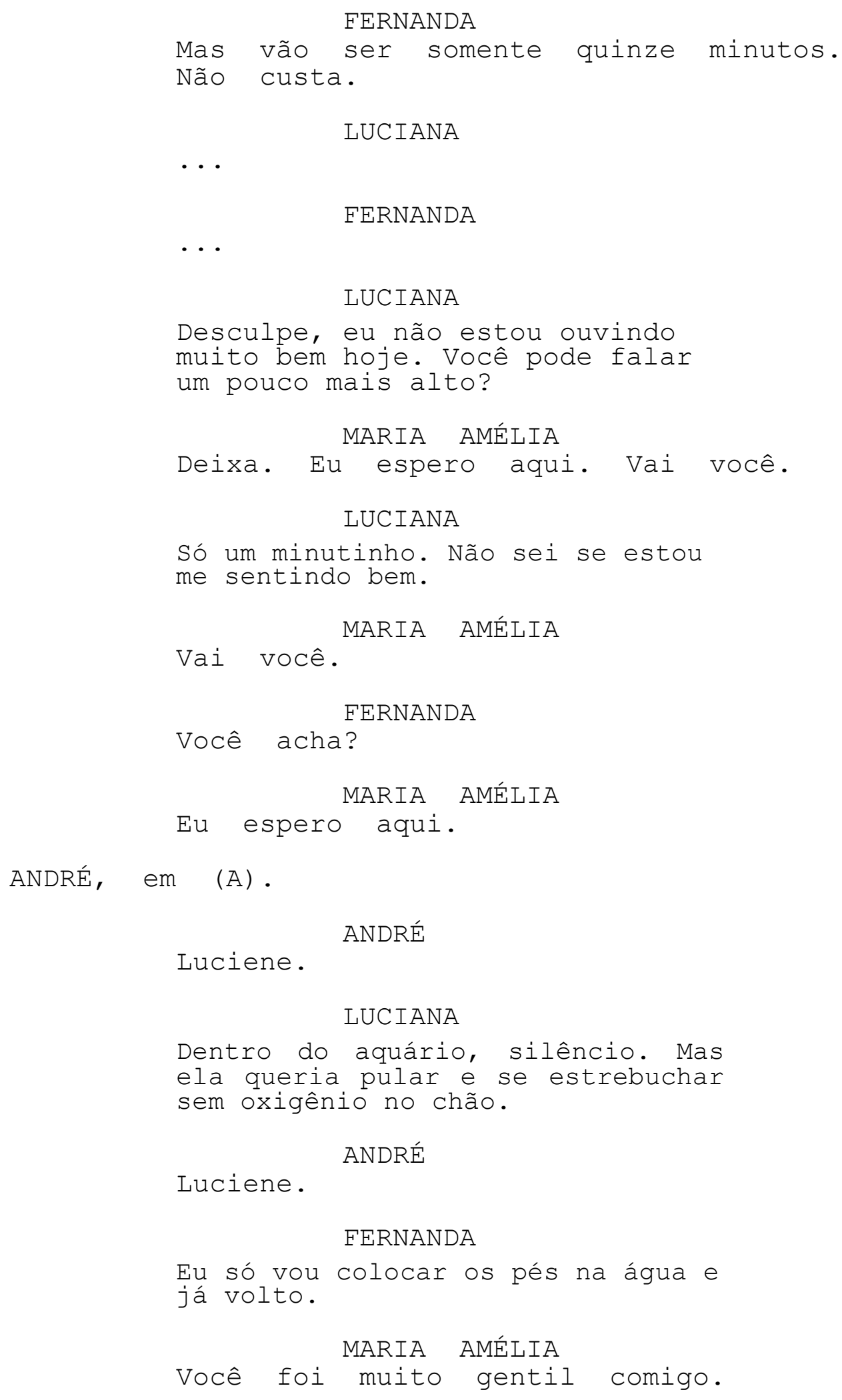

\section{ANDRÉ}

Luciene.

LUCIANA

Dentro do aquário, silêncio. Mas ela queria pular e se estrebuchar sem oxigênio no chão.

ANDRÉ

Luciene.

FERNANDA

Eu só vou colocar os pés na água e já volto.

MARIA AMÉLIA
Você foi muito gentil comigo.


FERNANDA

Você também foi um amor. Obrigada

por ter sido sincera comigo.

(entrega o pano de volta para

ela). Obrigado. Quando o Cassiano

vier de Brasília, nós podíamos...

ANDRÉ

Luciene.

LUCIANA

(voltando a escutar,

interrompendo)

Eu sinto muito. Eu tenho que ir.

FERNANDA, entra. LUCIANA vai até (A) e fica ajudando ANDRÉ. MARIA AMÉLIA fica do lado de fora.

CENA 8

(C.fundo)

PAULA

$\mathrm{C}-\mathrm{H}-\mathrm{U}-\mathrm{V}-\mathrm{A}$. Avisar $\mathrm{N}-\mathrm{O}-\mathrm{I}-\mathrm{VO}$. Vou te deixar com a Luciana.

FLÁVIA não quer sair de perto da piscina. PAULA a obriga.

Vai com ela até a portaria, não encontra LUCIANA.

$$
\text { Me espera aqui, Flávia. Aqui. }
$$

PAULA vai em direçào a (A) .

CENA 9

(C. esq)

FERNANDA entra no clube, esbarra em O MENINO.

\section{FERNANDA}

Fernanda sentiu os primeiros pingos

da chuva e achou que aqueles

segundos poderiam não acabar nunca.

Apertou bem a barriga até sentir um certo enjôo, pra ter certeza de que estava sozinha. Teve.

MENINO

Desculpe, estou sem meus óculos. 


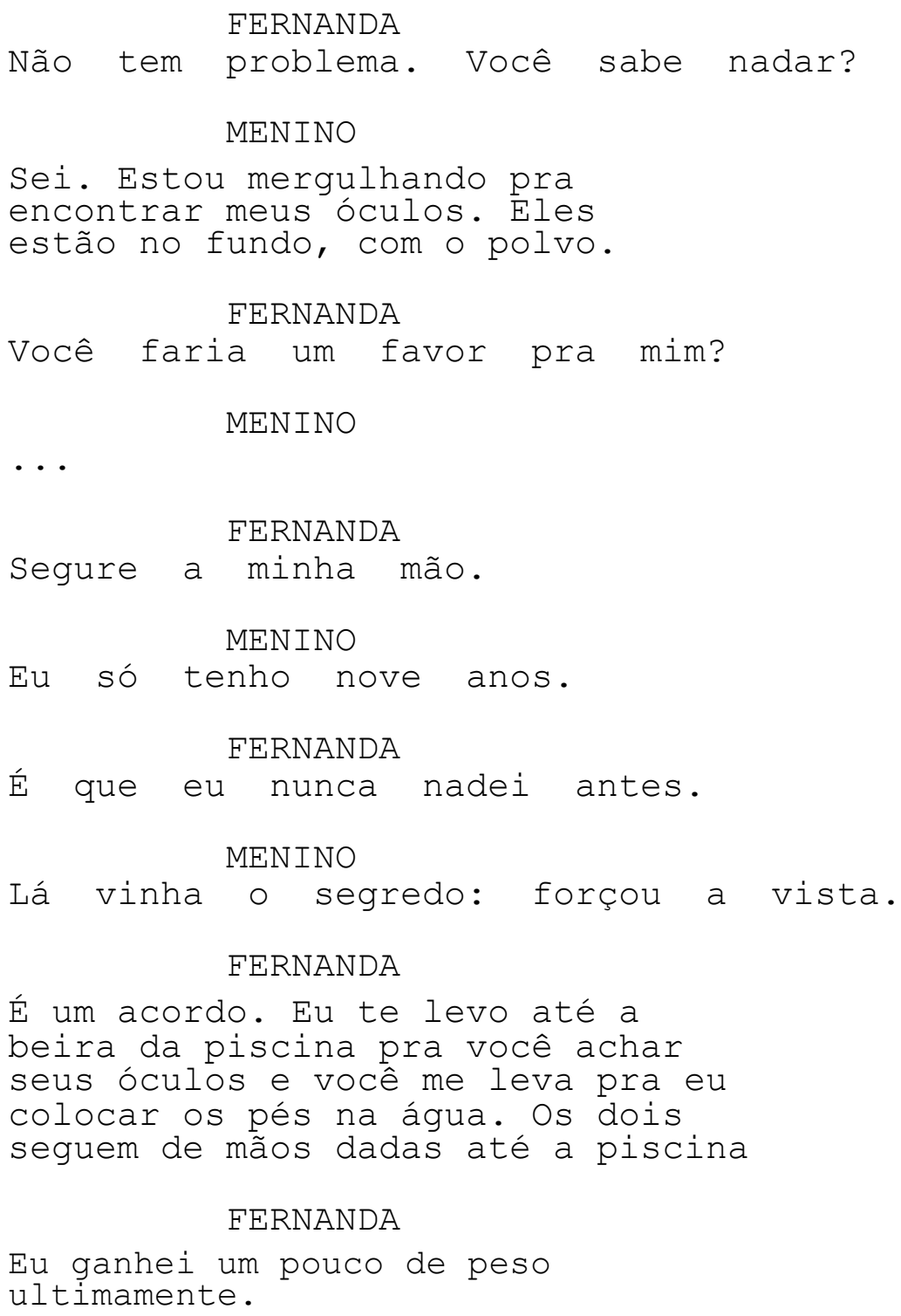

MARIA AMÉLIA observa PAULA com FLÁVIA. PAULA deixa FLÁVIA sozinha e vai falar com ANDRÉ. MARIA AMÉLIA e FLÁVIA de mãos dadas, de costas. 
CENA 11

(A) - refazer cena

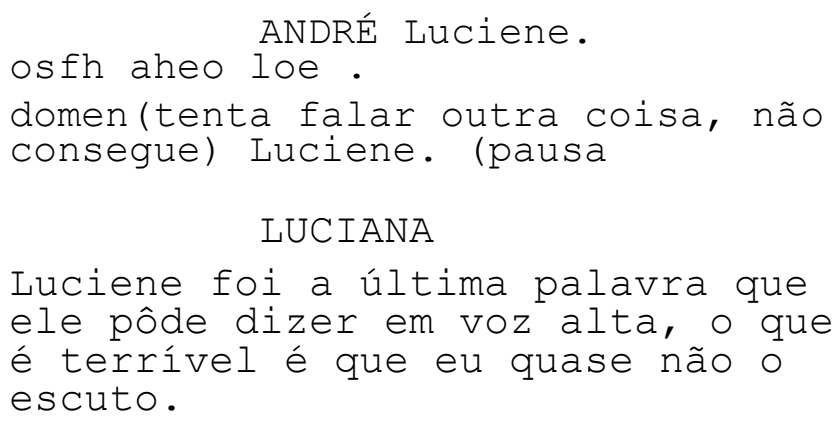

ANDRÉ Luciene.

osfh aheo loe.

domen(tenta falar outra coisa, não consegue) Luciene. (pausa

LUCIANA

Luciene foi a última palavra que ele pôde dizer em voz alta, o que é terrível é que eu quase não o escuto.

\section{ANDRÉ}

Luciene. Luciene.ahvo hoenobm

\section{LUCIANA}

Ele está segurando sua última palavra: meu nome. E eu quase não o ouço. Não é uma reclamação, ele não está me chamando. É uma oração. Quer saber se eu o amo, isso é tudo que todo mundo quer dos outros, não o amor em si, mas sim o conhecimento de que o amor está presente como lâmpadas novas num abajur quebrado.

\section{ANDRÉ}

ahlenn olenho loombpons

luciene ANDRÉ lhe entrega os

seus guardanapos. PAULA chega.

PAULA

Luciana .

LUCIANA

err... d-d-dona paula, eu não sei - que aconteceu... ele está dizendo...

\section{ANDRÉ}

Luciene.

LUCIANA

O meu nome.

PAULA e LUCIANA ajudam ANDRÉ, cada vez mais em pânico. 
PAULA

O medo da chuva não a deixa escutar mais do que o seu coração acelerado diante das crianças que pulam espirrando muita água, dos jovens nadadores ajeitando a sunga antes do salto.

\section{ANDRÉ}

hoh., en. luciene. (mostra os guardanapos a Paula)

PAULA

Vamos fazer o seguinte: vamos pra casa. Vamos pra casa. Paula sabia que não era hora de ir embora. Não com aquela chuva. Vai chover muito. Luciana, avisa que o Torneio foi cancelado e que... que... comemoraremos amanhã a

$$
\text { LUCIANA }
$$

emancipação

\section{PAULA}

emancipação de Arujá. Pede pra avisarem no altofalante.

LUCIANA fica parada.

$$
\text { Pode ir. Eu cuido dele. }
$$

LUCIANA sai .

$$
\text { PAULA }
$$

Me espera aqui. Eu vou buscar a menina e já volto.

Vai procurar FLÁVIA. De costas.

CENA 12

(B)

ALINE e THIAGO se reencontram. Ela o abraça.

\section{ALINE}

[eu queria te avisar que vai começar a chover. Pra você não se molhar. estava preocupada] 
THIAGO

(libras) Eu gosto de chuva. Eu vou embora.

ALINE

[gosta chuva. Mas achei que você

ia voltar pra sempre. você já

tinha avisado. nas fotografias]

THIAGO

(libras) Eu vou embora.

ALINE

[ir embora. não vai ficar pro torneio?]

THIAGO

(libras) Com essa chuva?

[chuva]

\section{ALINE}

THIAGO se despede, vai até C.esq. De costas. Aline fica sozinha, de costas.

CENA 13

(C.dir)

LUCIANA chega para falar com DANIELA

LUCIANA

Eu trouxe um novo recado. (pausa, olhas os guardanapos) Pra adiar o torneio, por causa dessa ameaça de chuva.

\section{DANIELA}

Ele esteve aqui, Luciana. Pegou na minha mão, fez carinho no meu rosto...

\section{LUCIANA}

Daniela, está me ouvindo? Eu tenho um recado.

\section{DANIELA}

Eu vou até a piscina. Talvez ele ainda esteja lá enquanto eu fico aqui, parada. 


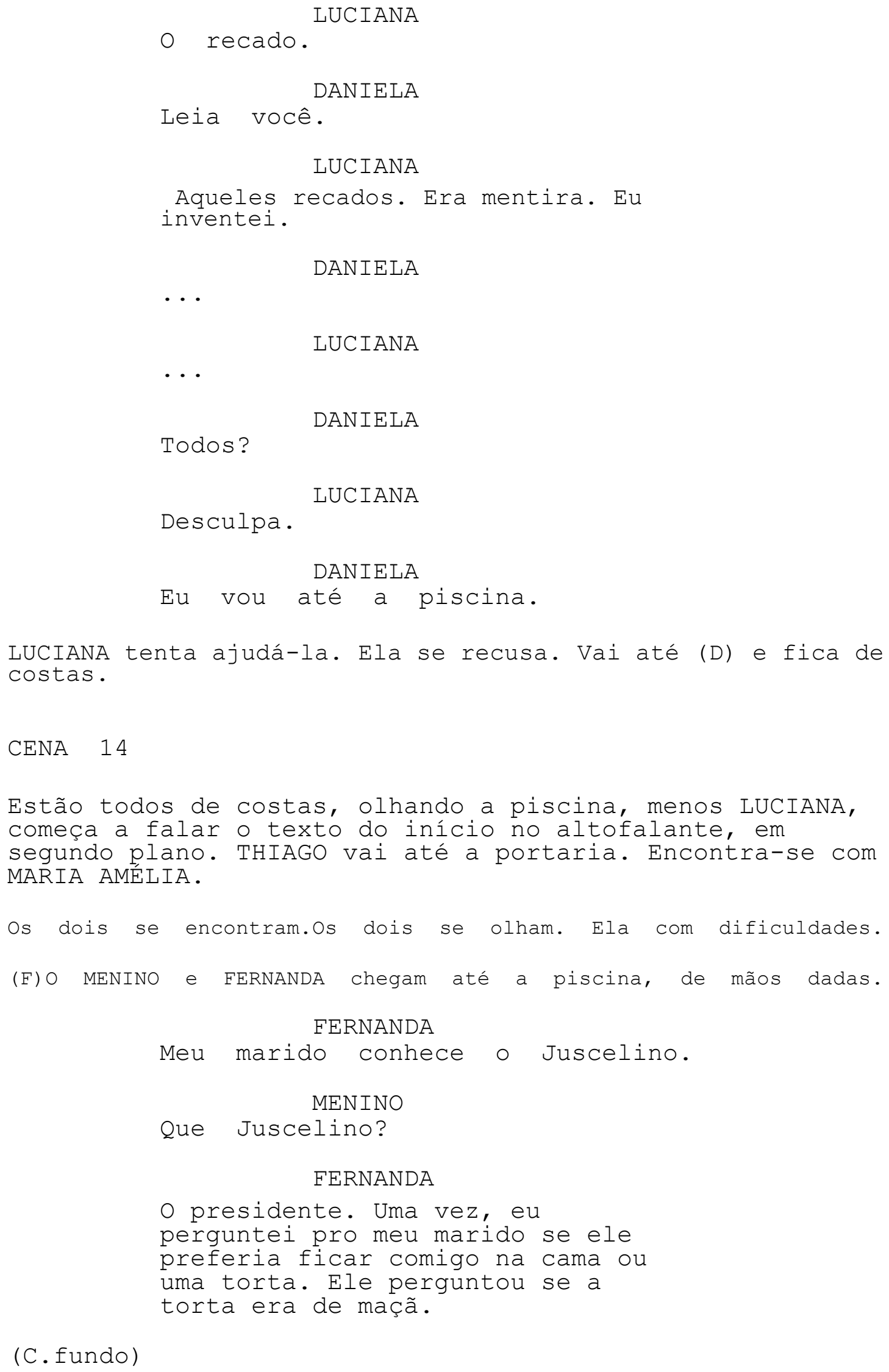

(C.fundo) 
MARIA AMÉLIA e THIAGO.

MARIA AMÉLIA

Eu ouvi falar de você. São fotos, posso ver?

THIAGO lhe entrega as fotografias.

\section{MARIA AMÉLIA}

Posso ler ou é segredo? (lendo) E se

viram como velhos parados diante da

piscina, cinqüenta anos depois,

debaixo da mesma tempestade.

Os dois se beijam e saem do clube.

Começa a chover.

(C.dir)

LUCIANA no altofalante.

\section{LUCIANA}

...pessoalmente, gostaria de

lembrar a todos que a apresentação

da carteira de sócio do clube é

imprescindível para o uso da

piscina. Boa tarde a todos, a

Diretoria Há uma longa pausa.

$(\mathrm{F})$

\section{FERNANDA}

Mergulha atrás dos seus óculos. Eu te espero aqui, com os pés na água.

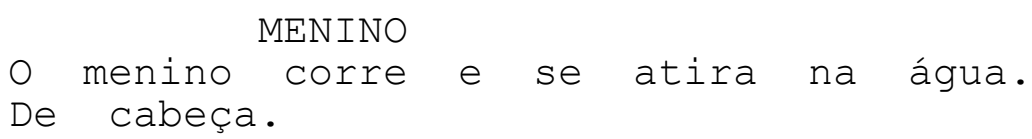

Outros de costas. André em A. Paula e Flávia em C.dir.

Daniela em D. Aline em B. Luz vai aumentando. Muito branco.

$$
\text { LUCIANA (V.O) }
$$

Por favor, saiam da piscina.

Afastem-se da piscina imediatamente. Por favor, por favor, por favor...

A voz desaparece. FIM. 